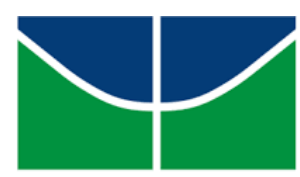

Universidade de Brasília

Centro de Desenvolvimento Sustentável

\title{
Sustainable future for
} Biodiesel in Brazil: perspectives for 2030

\author{
MARIA AMÉLIA DE PAULA DIAS
}

Brasília, DF, Brazil

February 2016 
UNIVERSITY OF BRASILIA

CENTRE OF SUSTAINABLE DEVELOPMENT

UNIVERSITY OF COPENHAGEN

DEPARTMENT OF GEOSCIENCES AND NATURAL RESOURCES MANAGEMENT, SECTION FOR FOREST, NATURE AND BIOMASS, FACULTY OF SCIENCE,

Sustainable future for biodiesel industry in Brazil: perspectives for 2030

MARIA AMÉLIA DE PAULA DIAS

SUPERVISOR IN BRASILIA: JOÃO NILDO DE SOUZA VIANNA

SUPERVISOR IN COPENHAGEN: CLAUS FELBY

PhD Thesis (TESE DE DOUTORADO)

BRASILIA, DF BRAZIL, FEBRUARY 2016 
Dias, Maria Amélia de Paula

Sustainable future for biodiesel industry in Brazil: perspectives for 2030/ Maria Amélia de Paula Dias.

Brasilia Brazil, 2016

179 p.: IL.

PhD Thesis, University of Brasilia, University of Copenhagen

1. Scenarios, biodiesel, 2.National biodiesel production simulation, feedstock 3.Sustainability in scenarios methods

II. Títle

BRAZIL, 2016

The total or partial reproduction and distribution of this work is authorized by any conventional means or electronic, for purposes of study and research, since the source is cited.

É concedida à Universidade de Brasília permissão para reproduzir cópias desta tese e emprestar ou vender tais cópias, somente para propósitos acadêmicos e científicos. A autora se reserva outros direitos de publicação e nenhuma parte desta tese de doutorado pode ser reproduzida sem a autorização por escrito da autora. 
UNIVERSITY OF BRASILIA

CENTRE OF SUSTAINABLE DEVELOPMENT

\title{
UNIVERSITY OF COPENHAGEN
}

DEPARTMENT OF GEOSCIENCES AND NATURAL RESOURCES MANAGEMENT, SECTION FOR FOREST, NATURE AND BIOMASS, FACULTY OF SCIENCE,

\section{Sustainable future for biodiesel industry in Brazil: perspectives for $\mathbf{2 0 3 0}$}

\author{
Maria Amélia de Paula Dias
}

Thesis presented to Centre for Sustainable Development, at University of Brasilia and to Department of Geosciences and Natural Resources Management, Section for Forest, Nature and Biomass, Faculty of Science, at University of Copenhagen, in partial fulfilment of the requirements for the degree of Doctor of Sustainable Development-Policy and Sustainability Management (Política e Gestão da Sustentabilidade)

Assessment committee

Prof Dr. Saulo Rodrigues Pereira Filho Institution University of Brasilia President of the committee

Prof Dr. Carsten Smith-Hall Institution University of Copenhagen

Prof Dr. Elimar Pinheiro do Nascimento Institution University of Brasilia

Prof Dr. Thomas Ludweigs

Institution University of Brasilia

Prof Dr. Elaine Coutinho Marcial

Institution: IPEA - Institute for Applied

Economic

External member

Brasilia (DF), Brazil, February $4^{\text {th }}, 2016$. 


\section{ACKNOWLEDGEMENTS}

A PhD thesis is a very lonely work, as can be expected. However, many people directly and indirectly contribute in different ways. I may have forgotten to mention someone in this section, for that, I apologize in advance. Let's see.

I would like to thank all my $\mathrm{PhD}$ colleagues in Brazil, in alphabetic order: Andrea, Arnoldo, Bruno, Catherine, Chiara, Daniela, Leonardo, Luiz, Marcos and Veronica. The discussions during the classes were very, very important and fruitful. A very especial thank to Catherine for accepting to be my English reviser. I am omitting the family names on purpose. Just to keep it informal. I also thank the professors of the Centre for Sustainable Development - CDS. It will be difficult to name everybody, because even those who were not teaching were important by sharing discussions and conversations. I could not forget all the employees at CDS. They make our academic life easier. I owe special appreciation to Leonardo Conke, for his friendly emails while I was in Denmark, which helped me feel attached to my Brazilian origins.

I also must thank to all people I knew in Denmark. I would like to start with Professor Ole John Nielsen. Without him, I would not have gone to Denmark. His personal and professional supports were also very important to keep me there, so far away from home. I also thank Søren Larsen, my roommate, for all the assistance he gave me in Copenhagen and also for fruitful discussions; and all the students and the KU employees I had the opportunity to meet at Copenhagen University. My special thanks to Niclas Bentsen for the co-supervision. His professional competence is outstanding. Still talking about Denmark, I sincerely thank all Brazilians I met there. They helped me to feel at home. I could not forget to say that thanks to Vera and Alex I have the sammendrag.

My special thanks to Professor Gerd Sparovek (from ESALQ) that I met in Göteburg, Sweden. His knowledge about Brazilian agriculture is awesome. He really helped me a lot making valuable suggestions about the Brazilian agriculture production and land use.

I also thank all people who agreed to participate in the interview, the pre-test questionnaire and the Delphi survey. Without them, this work would not have been possible. Special thanks to Julio Minelli, for accepting participate in the pre-defence and for giving valuable feedback.

Of course my friends and my family could not be left out of this page. It is very hard to mention all Brazilian friends that were very understandable and supportive during the $\mathrm{PhD}$ period. I thank all of them. I thank all my family, sisters, brother, stepmother, cousins, nephews, nieces and so on (Brazilian families are big and diverse) for the emotional support. My special thanks to Lília and Vítor, my beloved daughter, and son, and to Éguimo for keeping themselves very close to me. 
Finally, I mention my supervisors: João Nildo de Souza Vianna and Claus Felby. To João, I thank him for his constant guidance and patience. More than a supervisor, João was essentially a mentor. He led me into the academic world, after my business life. To Claus, besides accepting me at Copenhagen University, he was continuously very caring. $\mathrm{He}$ believed me without knowing me. I was extremely lucky for having two extremely competent and professional supervisors. Thank you both very, very much. I hope I met their expectations. 
The best way to predict the future is to create it. Assigned to Peter Drucker 


\section{ABSTRACT}

This thesis aims to study alternatives to biodiesel industry in Brazil, for 2030, taking in account the sustainability dimensions, namely economic, environmental, ecological, social, national and international politics, territorial, cultural, and technological, through the development of scenarios. In order to carry on this work, it was necessary to develop a cross-disciplinary research, since sustainability requires a long run vision and a comprehensive approach.

Brazil is a large country ( $851 \mathrm{Mha}$ ), with soil and weather conditions that are suitable to produce oilseeds, and available land for agriculture and pasture. Thus, a simulation, using linear programming models, was made in order to verify the alternatives of feedstock to produce biodiesel. It was observed that it is possible to decentralize the market, reduce land use, and regionalize production, making better use of the availability of existing oil and waste today.

A methodological discussion was also necessary to include sustainable dimensions on the scenario methods. Therefore, the environment, economics, technology, social, territorial, national and international institutional, cultural and political aspects were considered to identify the driving forces to develop the scenario storylines. This proposition was tested in an in-depth interview with the biodiesel market stakeholders.

Based on the findings of the two approaches, the simulations and the interviews, it was possible to obtain future alternatives, where the biodiesel production chain could be a catalyst for environmental improvement and social inclusion as well as being economically viable and contribute to energy security. The set of four scenarios for the biodiesel industry in Brazil, for 2030, was built as the final result of the work. They are: a) Business as usual (BAU) - considering the continuation of the current industry dynamics; b) Step-by-step (SBS), bringing sustainability to environmental gains, social and regional integration. It is based on environment conservation and better use of degraded and marginal lands; c) Abundance $(A B C)$ that takes advantage of technological breakthrough added to environmental and regional bias on the biodiesel production; and d) Scarcity (SCR) representing a deterioration of the current situation, with little environmental care, without recovering of degraded lands, and few technological advances in biodiesel production.

The SBS and ABC scenarios show alternatives for the biodiesel industry that includes the sustainable dimensions. However, the other scenarios show possibilities that are also plausible. A Delphi survey assessed the coherency and plausibility of the scenarios. ABC scenario - was evaluated as more coherent and plausible than the SCR scenario. It may suggest that it is easier to believe in a technological breakthrough than the climate change consequences. 


\section{SAMMENDRAG}

Denne afhandling har som formål at udvikle scenarier for biodiesel industrien i Brasilien i 2030, forhold til en række bæredygtige faktorer såsom: økonomi, miljø, økologi, sociale, nationale og international politik, territorialt, kulturelt og teknologisk, gennem udvikling af scenarier. For at udføre denne opgave, er der anvendt en tværfaglig forsknings tilgang, da bæredygtighed forudsætter en langsigtet horisont og en samlet strategi.

Brasiliens størrelse $\left(8,5\right.$ millioner $\left.\mathrm{km}^{2}\right)$, med jord og vejrforhold der er egnet til at både vegetabilske or animalske landbrugsprodukter gjorde en at en både overordnet og lokal tilgang blev anvendt. Således blev en simulering, ved hjælp af lineære programmerings modeller, lavet for at verificere alternativ råmaterialer til produktion af biodiesel. Det blev fundet, at sammenholdt med den nuværende situation er det muligt både at decentralisere markedet, reducere arealanvendelsen, og regionalisere produktionen, samt forbedre udnyttelsen af tilgængeligheden af eksisterende olie og residualt affald.

Det var også nødvendigt at inkludere en metodediskussion for at medtage de bæredygtige dimensioner i udviklingen af de forskellige scenarier. Både miljø, økonomi, teknologi, sociale, territoriale, nationale og internationale institutionelle, kulturelle samt politiske aspekter blev identificeret som de drivende kræfter i udviklingen af scenarie storylines. Inklusionen af dette forslag blev efterprøvet $\mathrm{i}$ et dybdegående interview med interessenter på biodiesel markedet.

Baseret på resultaterne af de to tilgange; simuleringer og interviews, var det muligt at udvikle fremtidige alternativer, hvor biodiesel produktionskæden kunne være en katalysator for miljøforbedring og social integration, og samtidig være økonomisk rentable og bidrage til energisikkerheden. På den baggrund blev fire scenarier for biodiesel industrien i Brasilien, for 2030, udviklet. Scenarierne er: a) Status quo (SQ) - en fortsættelse af den nuværende industri og forretningsmodeller; b) Trin-for-trin (TFT), skabende bæredygtige miljøgevinster, samt social og regional integration. TFT er baseret på miljøbevaring og bedre udnyttelse af næringsfattige og marginale jorder; c) Overflod (OVF), skabende bedre miljøbeskyttelse sammen med teknologiske gennembrud indenfor brændser og motorteknologi, samt og i regional produktion af biodiesel; og d) Knaphed (KNP) - der repræsenterer en forværring af den nuværende situation, med begrænset miljøbeskyttelse, uden genopretning af udpinte jorder, og få teknologiske fremskridt i produktionen af biodiesel. En Delphi-undersøgelse vurderede sammenhæng og sandsynlige scenarier.

TFT og OVF scenarier viser alternativer for biodiesel industrien, der indbefatter bæredygtige dimensioner. Mens de øvrige scenarier viser muligheder, der også er plausible. 
OVF scenariet - blev evalueret som mere sammenhængende og troværdig end KNP scenariet. Dette kan tyde på, at det er lettere at tro på teknologiske gennembrud snarere end konsekvenser af klima forandringer. 


\section{Resumo}

Esta tese tem o objetivo de estudar as possibilidades para a indústria do biodiesel no Brasil, para 2030, levando em consideração as dimensões de sustentabilidade de Sachs: econômica, ambiental, ecológica, social, politica nacional e internacional, territorial, cultural e tecnológica, por meio do desenvolvimento de cenários prospectivos. Para tanto, foi necessário desenvolver um trabalho multidisciplinar, partindo do pressuposto que sustentabilidade requer visão de longo prazo e uma abordagem abrangente.

Brasil é um país de grandes dimensões - 851 Mha- com condições edafológicas adequadas para produzir oleaginosas, e com tem terra disponível para agricultura e pastagens. Por isso, foi necessário uma simulação de produção de biodiesel, usando programação linear, para verificar se haveria alternativas de escolha de outras matérias primas com o que estava disponível em 2013. Os resultados mostraram que é possível desconcentrar o mercado, reduzir uso da terra e regionalizar a produção, fazendo melhor uso dos óleos produzidos e dos resíduos (óleo usado e gordura animal).

Foi necessário também passar por uma discussão metodológica para incluir as dimensões de sustentabilidade nos métodos de desenvolvimento de cenários. Somente depois desta etapa, foi possível utilizá-las para identificar as forças motrizes para desenvolver os enredos dos cenários. A proposta de inclusão destas dimensões foi testada em uma entrevista em profundidade com os atores do mercado brasileiro de biodiesel.

Baseado nos achados dos dois procedimentos - as simulações e as entrevistas - foi possível obter alternativas de futuro, onde a cadeia produtiva do biodiesel fosse uma catalizadora da melhoria dos cuidados ambientais e da inclusão social, economicamente viável e contribuir com a segurança energética. Como resultado final do trabalho, um conjunto de quatro cenários para a indústria do biodiesel no Brasil para 2030 foi então elaborado. Eles são: a) Tendencial (TD), onde se considera que a dinâmica atual da indústria do biodiesel continue a mesma; b) Passo a passo (PP), que traz sustentabilidade aos ganhos ambientais, com integração social e regional; c) Abundância (AB), que traz os ganhos da conservação ambiental aliados às vantagens de novas tecnologias em combustíveis e em motores, e à produção regionalizada de biodiesel; e D) Escassez (ES), representando a deteriorização da situação atual, com pouco cuidado ambiental, sem recuperação de terras degradadas e pouco avanços tecnológicos na produção de biodiesel.

Os cenários PP e AB mostram alternativas para a indústria do biodiesel que inclui as dimensões de sustentabilidade. No entanto, os outros cenários também são plausíveis. Uma pesquisa Delphi avaliou a coerência e plausibilidade dos cenários. $O$ cenário $A B$ foi avaliado com um nível de coerência e plausibilidade maior que o Escassez. Isto pode sugerir que é 
mais fácil acreditar em avanços tecnológicos disruptivos do que nas consequências das mudanças climáticas. 


\section{LIST OF TABLES}

Table 1 - Biodiesel industry in Brazil, advantages, opportunities, risks and threats .............24

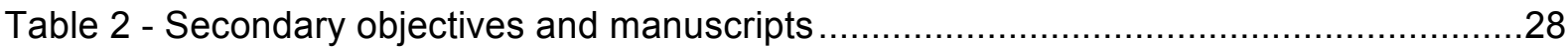

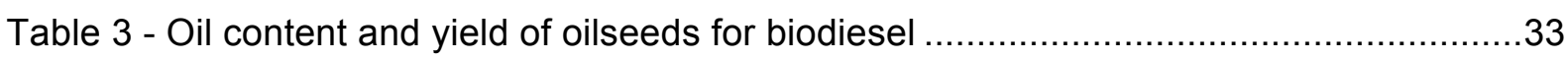

Table 4- Biodiesel production by Brazilian region (B100, million litters) ...............................41

Table 5 - Regional Human Development Index 2010 ......................................................42

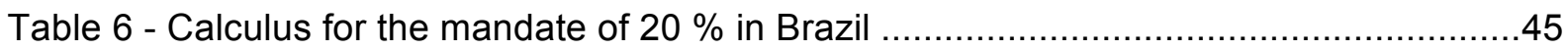

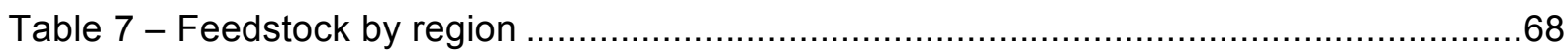

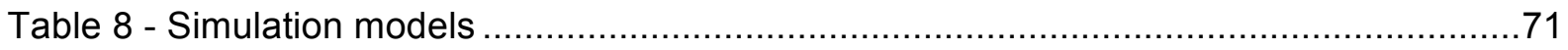

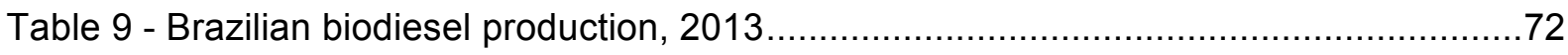

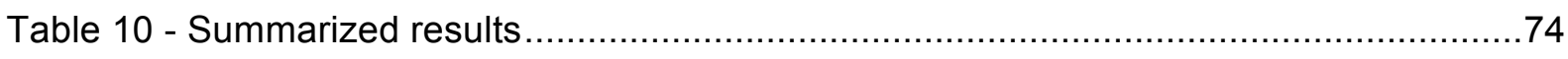

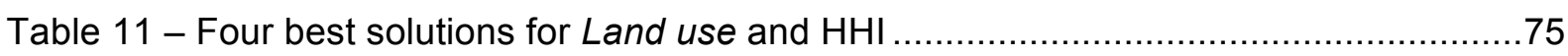

Table 12 - Results of maximize model to produce biodiesel in Brazil, in 2013 ......................76

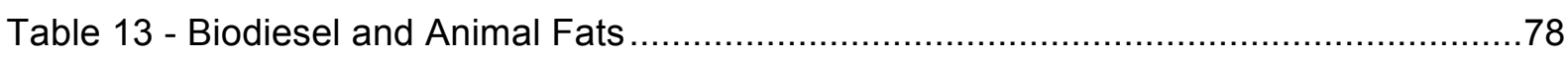

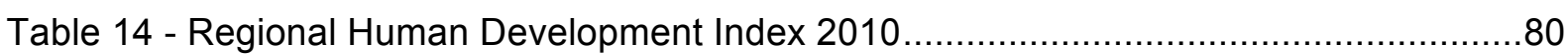

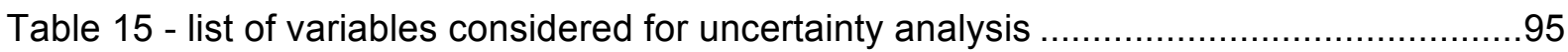

Table 16 - Driving forces that resulted from the simulation model .....................................98

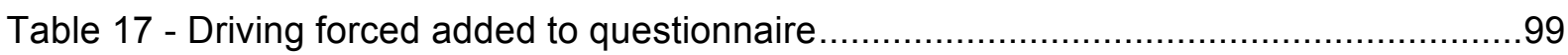

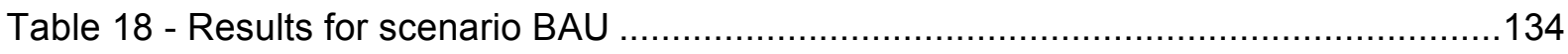

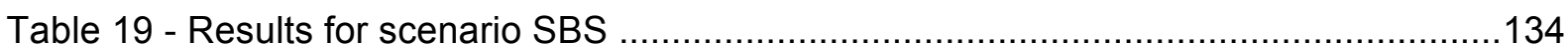

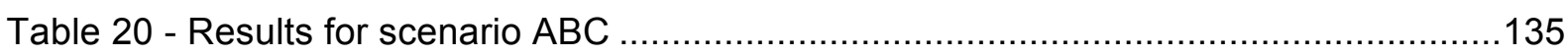

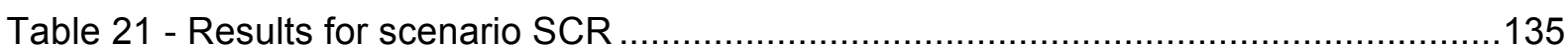

Table 22 - Summary of results for high and medium options ...........................................135 


\section{LIST OF FIGURES}

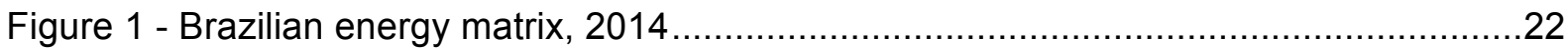

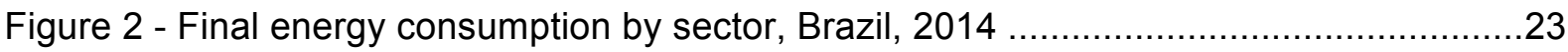

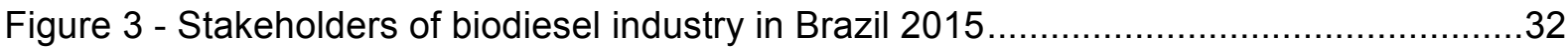

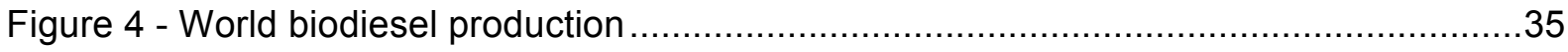

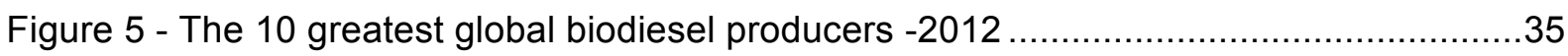

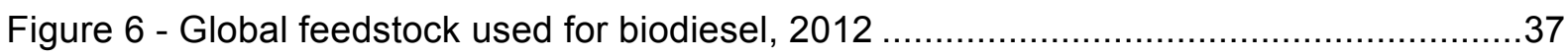

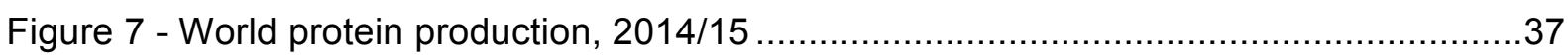

Figure 8 - Biodiesel Agro-industrial complex (AIC) from vegetables oil in Brazil...................40

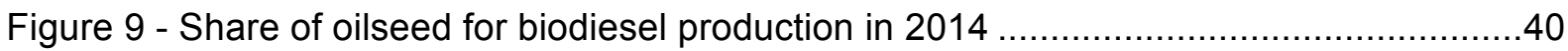

Figure 10 - Biodiesel, production x consumption, Brazil 2013 ....................................... 41

Figure 11 - The agro-industrial complex (AIC) of Biodiesel from beef tallow in Brazil...........43

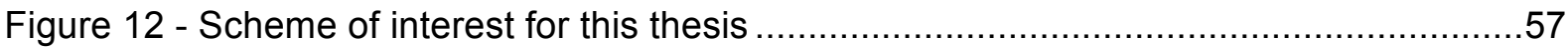

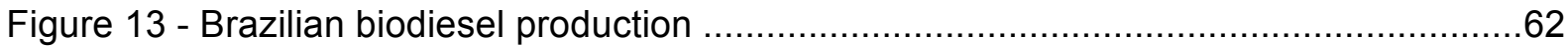

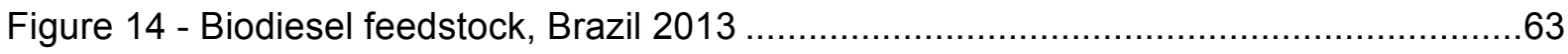

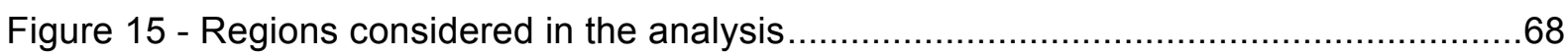

Figure 16. Brazilian biodiesel production vs Consumption (2013) ......................................79

Figure 17 - a resumed classification of the methods to develop scenarios ..........................88

Figure 18- the cause-effect relationship in the critical uncertainty level of response to climate

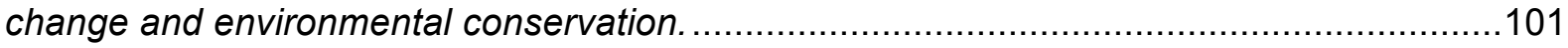

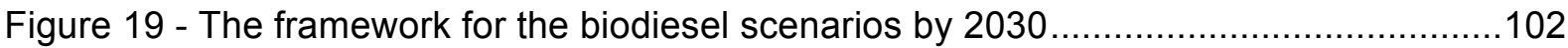

Figure 20 - Framework and the Scenarios for biodiesel production, by $2030 \ldots \ldots \ldots \ldots \ldots \ldots . . . .104$

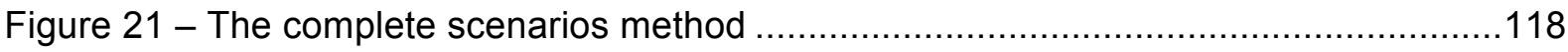

Figure 22 - Framework for scenarios for biodiesel production, by $2030 \ldots \ldots \ldots \ldots \ldots \ldots \ldots \ldots \ldots \ldots . . . . . . . . .119$

Figure 23 - Scenario matrix for the biodiesel industry in Brazil, 2030 ...............................129 


\section{LIST OF ACRONYMS}

\begin{tabular}{|c|c|}
\hline$A B$ & Abundância \\
\hline$A B C$ (scenario) & Abundance \\
\hline ABC Plan & Plano para Agricultura de Baixo Carbono \\
\hline AFS & Agroforestry Systems \\
\hline AIC & Agro-Industry complex \\
\hline AMYRIS & Name from a Research Company, from USA \\
\hline ANP & Agência Nacional de Petróleo \\
\hline APROBIO & Associação dos Produtores de Biodiesel do Brasil \\
\hline BAU & Business as usual \\
\hline BNF & Biological Nitrogen Fixation \\
\hline BTL & Biomass-to-liquids \\
\hline CGBIO/ & Coordenação Geral de Biocombustíveis, do Ministério \\
\hline & Desenvolvimento Agrário \\
\hline CNPE & Conselho Nacional de Petróleo \\
\hline CONDRAF & Conselho Nacional de Desenvolvimento Rural Sustentável e Solidário \\
\hline COP21 & Conference about the climate change 2015 \\
\hline EBC & Empresa Brasileira de Comunicação \\
\hline ECOLEO & $\begin{array}{l}\text { Associação Brasileira para Sensibilização, Coleta e Reciclagem de } \\
\text { Resíduos de Óleo Comestível }\end{array}$ \\
\hline EIA & Energy Information Administration (U.S.) \\
\hline EMBRAPA & Empresa Brasileira de Pesquisa Agropecuária \\
\hline EPE & Empresa de Pesquisa Energética \\
\hline ES & Escassez \\
\hline ESALQ & Escola Superior de Agricultura Luiz de Queiroz \\
\hline FAO & Food and Agriculture Organization \\
\hline FT & Fischer-Tropsch \\
\hline GBN & Global Business Network \\
\hline GHG & Green House Gas \\
\hline $\mathrm{GtCO}_{2}$ & Giga tons of Carbon Dioxide \\
\hline $\mathrm{GtCO}_{2} \mathrm{eq}$ & Giga tons of Carbon Dioxide equivalent \\
\hline HVO & Hydro-treated vegetable oil \\
\hline IBGE & Instituto Brasileiro de Geografia e Estatística \\
\hline IEA & International Energy Agency \\
\hline IFAD & International Fund for Agricultural Development \\
\hline
\end{tabular}




\begin{tabular}{|c|c|}
\hline ILPF & Integração Lavoura Pecuária e Floresta \\
\hline ILS & Intuitive Logic School \\
\hline IMAZON & Instituto do Homem e do Meio Ambiente da Amazônia \\
\hline INPE & Instituto Nacional de Pesquisas Espaciais \\
\hline IPCC & Intergovernmental Panel on Climate Change \\
\hline KNP & Knaphed \\
\hline LCA & Life Cycle Analysis \\
\hline MAPA & Ministério da Agricultura e Pecuária \\
\hline MAPITOBA & Maranhão, Piauí, Tocantins , Bahia \\
\hline $\mathrm{MCTI}$ & Ministério da Ciência, Tecnologia e Inovação \\
\hline MDA & Ministério do Desenvolvimento Agrário \\
\hline MDIC & Ministério do Desenvolvimento, Indústria e Comércio \\
\hline Mha & Millions of hectares/Milhões de hectares \\
\hline MME & Ministério das Minas e Energia \\
\hline OECD & Organization for Economic Co-operation and Development \\
\hline OVF & Overflod \\
\hline PDE2024 & Plano decenal de expansão de energia 2024 \\
\hline PNDRSS & Plano Nacional de Desenvolvimento Rural Sustentável e Solidário \\
\hline PNE2030 & Plano Nacional de Energia 2030 \\
\hline PNMC & Plano Nacional de Mudança Climática \\
\hline PNPB & Programa Brasileiro de Produção e uso de Biodiesel \\
\hline PP & Passo a passo \\
\hline PRA & Plano de Recuperação Ambiental \\
\hline PWC & Price WaterHouse Cooper \\
\hline REN21 & Renewable Global Status Report \\
\hline RS & Rio Grande do Sul \\
\hline SBS & Step-by-step \\
\hline SCR & Scarcity \\
\hline SEEG/OC & $\begin{array}{l}\text { Sistema de Estimativas de Emissões de Gases Efeito Estufa/Observatório } \\
\text { do Clima }\end{array}$ \\
\hline SNUC & Sistema Nacional de Unidades de Conservação \\
\hline SQ & Status Quo \\
\hline SPD & Sistema de plantio direto \\
\hline STEEP & Social, Technology, Economic, Environment, Politics \\
\hline STEP & Social, Technology, Economic, Politics \\
\hline STSP & Systems Thinking and Scenario Planning \\
\hline
\end{tabular}




$\begin{array}{ll}\text { TD } & \text { Tendencial } \\ \text { TFF } & \text { Trin-for-trin } \\ \text { UNEP } & \text { United Nations Environment Programme } \\ \text { UNWATER } & \text { World Water Day by Unesco } \\ \text { USDA } & \text { U.S. Department of Agriculture } \\ \text { USDOE } & \text { U.S. Department of Energy } \\ \text { WEC } & \text { World Energy Council } \\ \text { WEO } & \text { World Energy Outlook } \\ \text { WFP } & \text { World Food Programme } \\ \text { WWF } & \text { World Wide Fund for Nature }\end{array}$




\section{CONTENTS}

List of tables

List of figures

List of acronyms

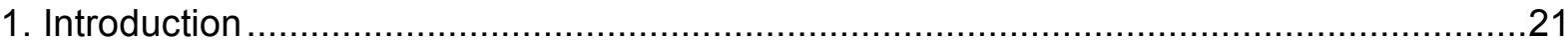

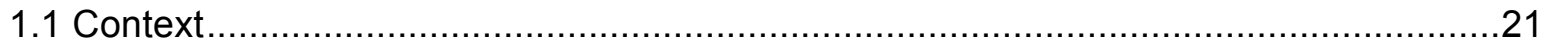

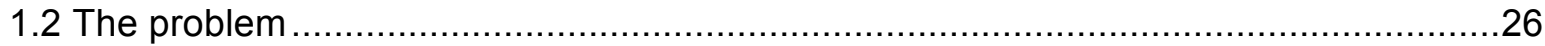

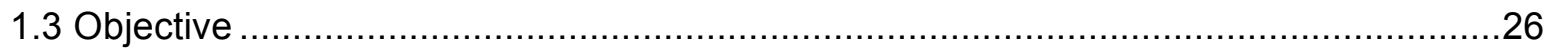

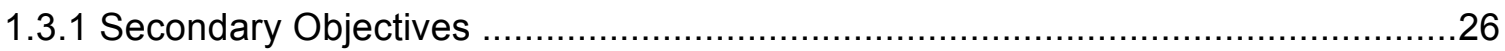

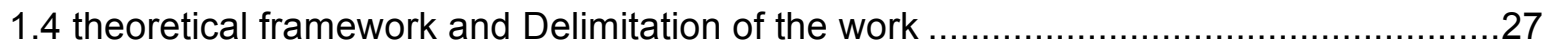

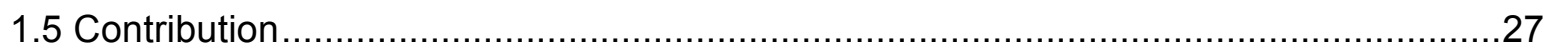

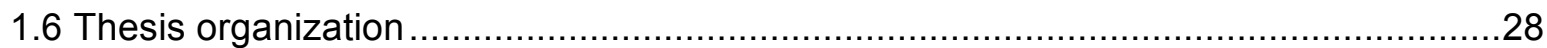

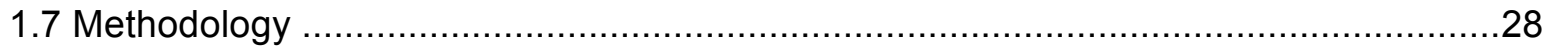

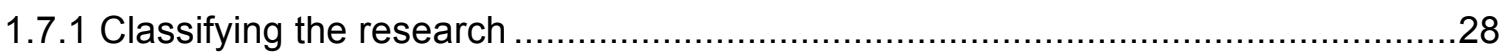

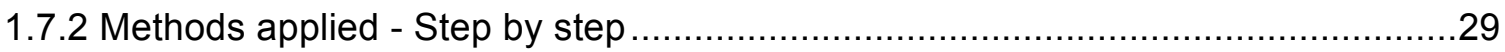

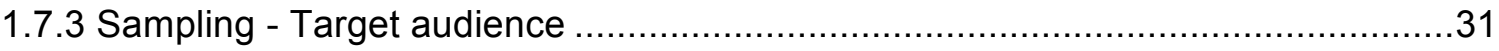

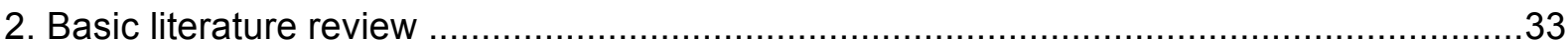

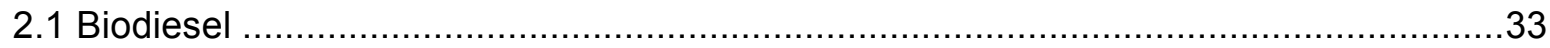

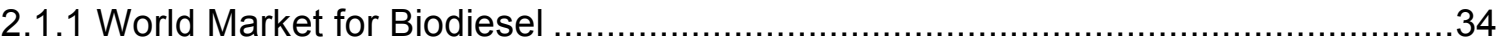

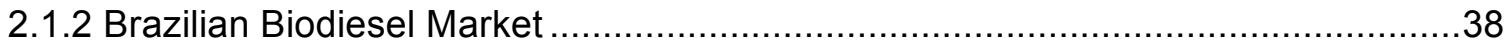

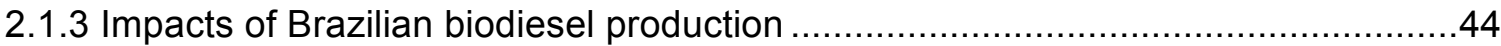

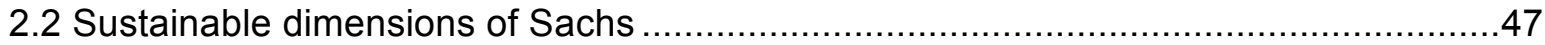

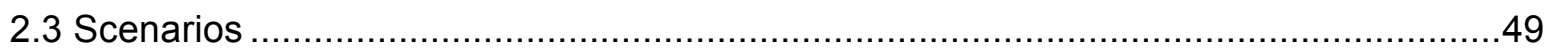

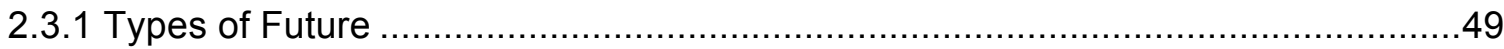

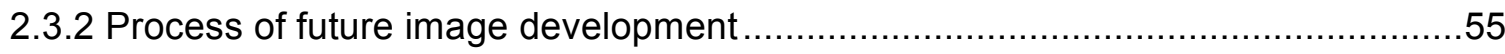

2.3.3 Common steps to develop scenarios - the dimensions of uncertainty ..................57

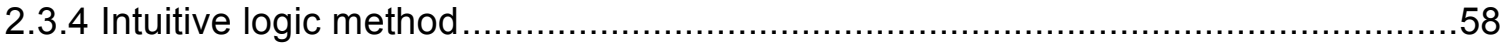


3.1 The choice of feedstocks for producing biodiesel: a case of Brazil ..........................61

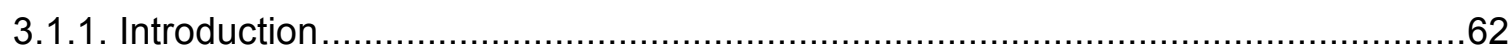

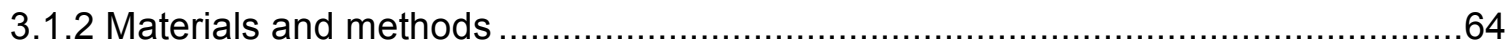

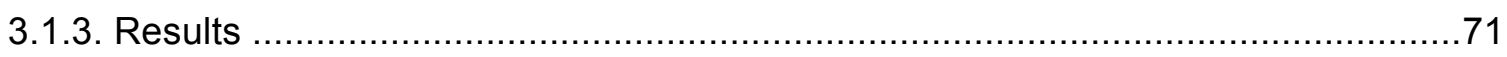

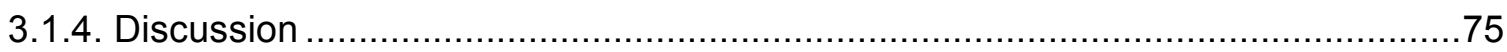

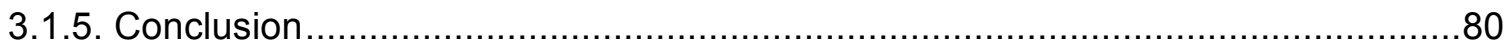

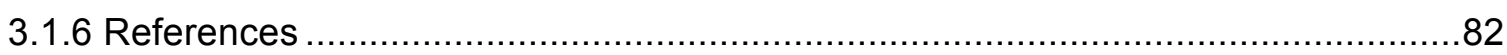

3.2 Sustainability in the prospective scenarios methods: a practical APPLICATION OF

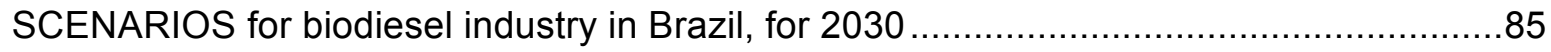

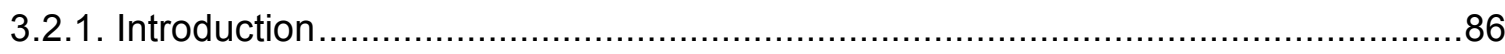

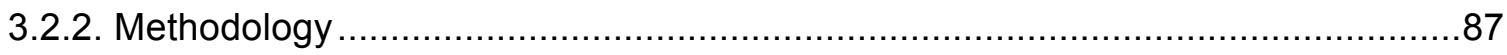

3.2.3. Analysis and discussion of the theoretical basis and the practical application......90

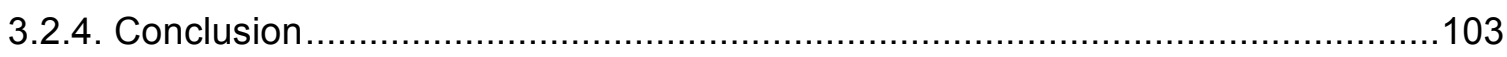

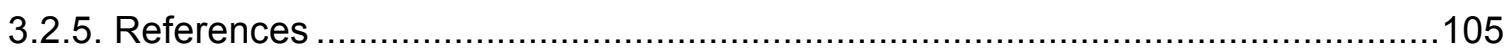

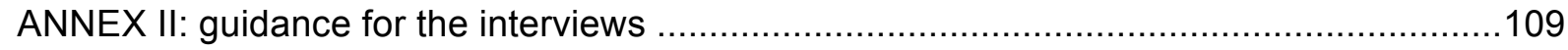

ANNEX III LIST OF PARTICIPANTES OF THE IN-DEPTH INTERVIEW .......................110

3.3 Integrating driving forces into storylines - the case of scenarios for the biodiesel

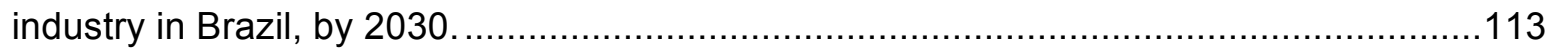

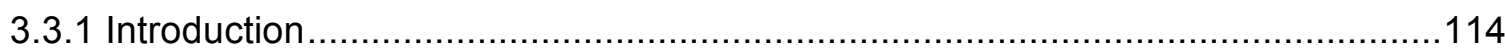

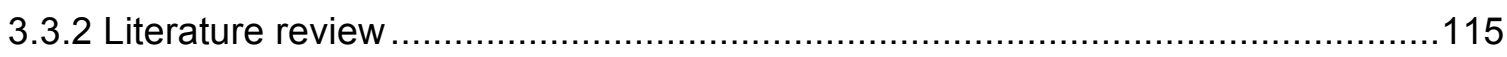

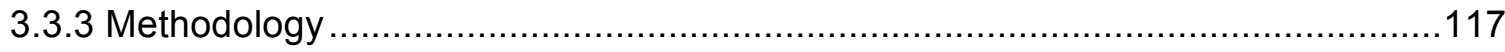

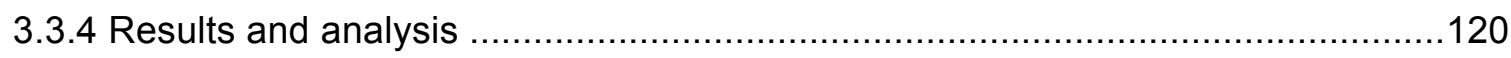

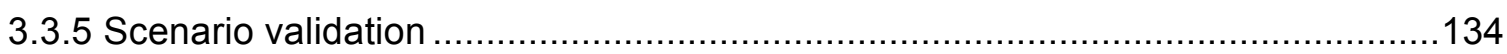

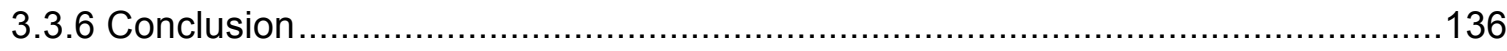

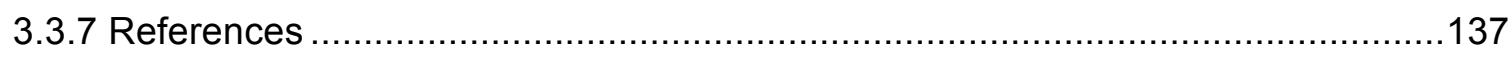

ANNEX IV: Delphi questionnaire and the answers of the first rounD ..............................143

Annex V: People who contributed to Delphi pre-test ......................................................151

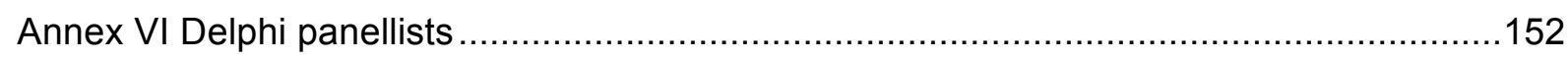




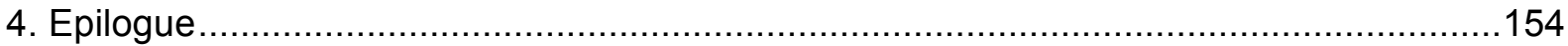

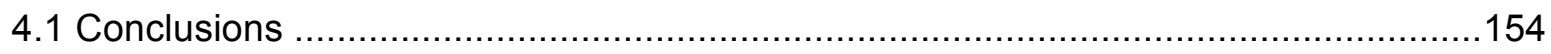

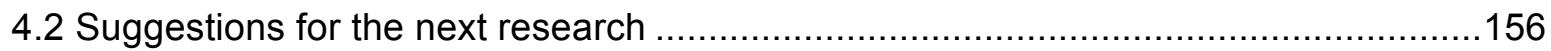

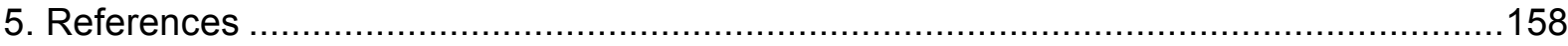

Annex I - Complete list of interviewees and panellists................................................ 175 


\section{INTRODUCTION}

\subsection{CONTEXT}

The efforts to limit a rise in temperature by $2^{\circ} \mathrm{C}$, by the twenty-first century would require an average reduction of $7 \mathrm{GtCO}_{2}$ eq by 2020 (UNEP, 2010). To accomplish the COP21 agreements made in Paris in 2015 , which limits the rise to 1.7 to $2^{\circ} \mathrm{C}$, the efforts should be even greater.

The energy sector represents two-thirds of the global greenhouse-gas (GHG) emissions (IEA, 2015b). The emissions in this sector include: electricity and heat generation $(42 \%)$, transports $(23 \%)$, industry $(19 \%)$, residential $(6 \%)$, services $(3 \%)$ and others $(7 \%)$ (IEA, 2015a). Whereas all assessments point to an increase in energy demand, it will be necessary to replace fossil fuels by other renewable sources that emit less $\mathrm{CO}_{2}$. The European Union has a mitigation plan that includes $27 \%$ of renewables until 2030 , but they privilege the second generation of biofuels for transports, limiting to $5 \%$ the share of biofuels from first generation (European-Commission, 2014).

The world transport consumption in 2012 was predominantly gasoline - 40\%, and diesel - 37\% (Doman \& Chase, 2015). Biofuels have been used to replace fossil fuels basically because they can reduce GHG emissions, decrease the dependence on oil imports, and require small or no changes in the engines. Biodiesel, the substitute biofuel for diesel, is produced and utilised in more than 60 countries in the world (Lane, 2016). It has been utilised up to $20 \%$ of blend to diesel. The largest producers are USA (19\%), Germany (16\%), Brazil (14\%) and Argentina (14\%) (EIA, 2015a). it was estimated that 169 million tonnes of GHG emissions were avoided in 2014 due to the use of biodiesel in the world (S\&T2, 2015). Only in Brazil, the reduction was 7.2 million tonnes ${ }^{1}$, which means $37 \%$ of the Central and South America total.

Brazil committed to reduce by $37 \%$ the GHG emissions below 2005 level $(2,2$ $\left.\mathrm{GtCO}_{2} \mathrm{eq}\right)$ by 2025 , and a second pledge of a further $43 \%$ reduction by 2030 as a commitment declared in the intended Nationally Determined Contribution (iNDC) for COP21 meeting (Brazil, 2015b). Currently, Brazilian emissions can be divided by sector as follows: Land use change (Luc) and forestry: 35\%, Energy: $29 \%$, agriculture: $27 \%$, industry: $6 \%$, and waste treatment: $3 \%$. If one accounts solely for net emissions, i.e. to the carbon capture in forests and protected areas, then the energy sector becomes the largest source of emissions, counting on 39\% of the total (SEEG/OC, 2015). Additionally, the energy sector in Brazil has had the greatest increase in emission in the last 15 years (SEEG/OC, 2015).

\footnotetext{
${ }^{1}$ Estimated based on (Gazzoni, 2012b)
} 
Conversely, in 2014 the Brazilian domestic energy supply contained a considerable participation of renewable sources: 39\% (Brazil, 2015a). The source for renewables energy are as follows: $40 \%$ of sugar biomass, $29 \%$ of hydropower, $21 \%$ of vegetal coal and productive forests and $10 \%$ others (Brazil, 2015a). From non-renewable sources, $65 \%$ of the energy comes from oil (Figure 1). The transport subsector consumes $35 \%$ of the energy, but is responsible for $47 \%$ of the emissions (SEEG/OC, 2015) (Figure 2). The sources of the energy used in Brazilian transport sector are: $48 \%$ of diesel (heavy vehicles, public and cargo transportation), $31 \%$ of gasoline (mandatory blend of 20 to $27 \%$ of anhydrous ethanol), $12 \%$ ethanol and the remainder in kerosene, fuel oil and others (SEEG/OC, 2015).

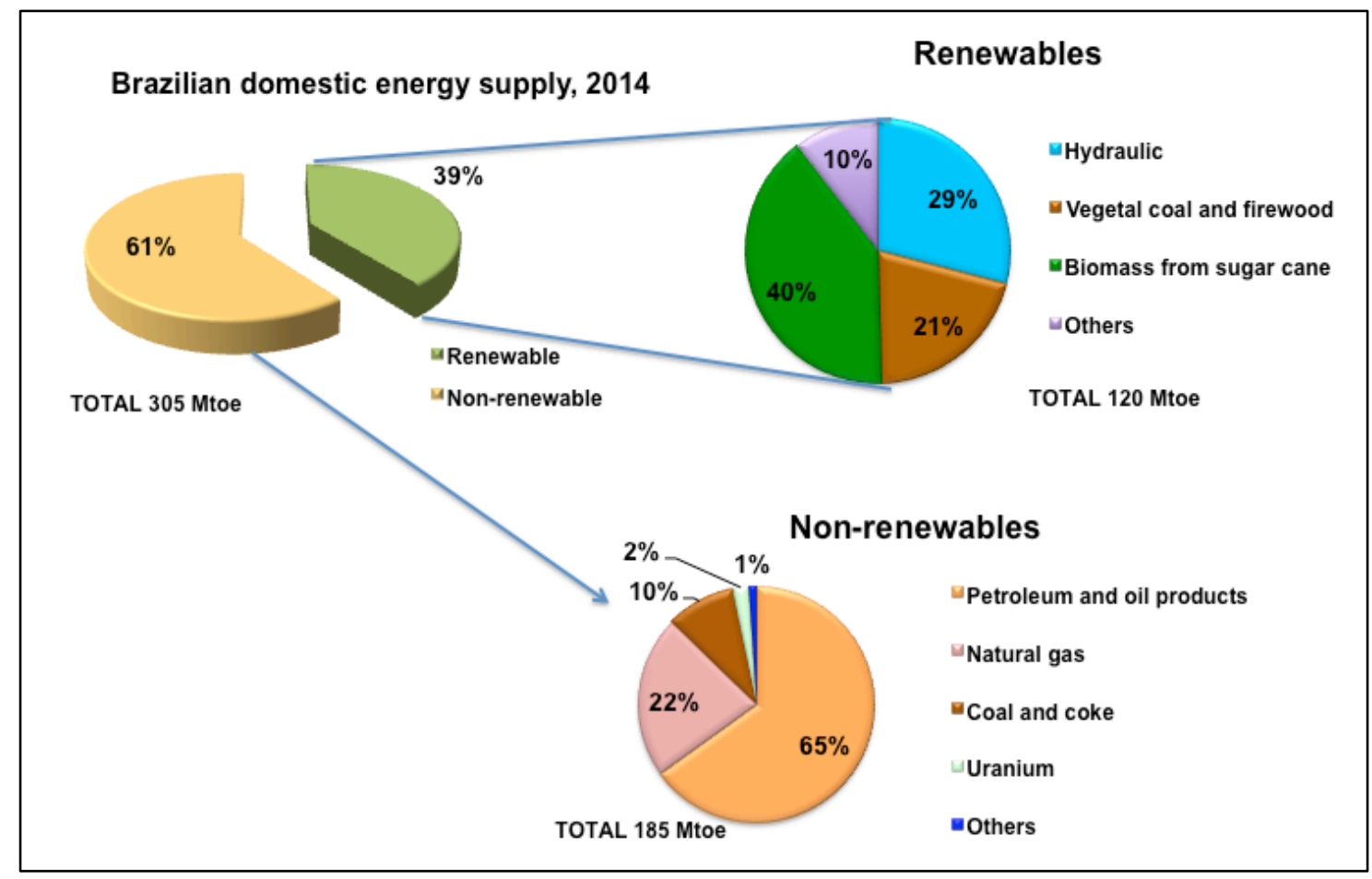

Figure 1 - Brazilian energy matrix, 2014

Source: Elaborated by the author based on BEN 2014 (Brazil, 2015a)

Diesel is crucial for the Brazilian economy. Over the vast 1.7 million $\mathrm{km}$ of federal roads (DNIT, 2012), $61 \%$ of the goods are transported by trucks (CNT, 2015). Diesel is also an important item with regards to import expenses. In 2014, it cost US $\$ 8.8$ billion. Being the greatest source of transport $\mathrm{CO}_{2}$, emissions it also has consequences for human health. It is estimated, in 2012 that in a large city like São Paulo, the costs of health treatment due to the 
pollution was roughly $\mathrm{R} \$ 84$ million $^{2}$. What is even worse, it is estimated that pollution has caused approximately 4600 deaths in the same year (Saúde-e-Sustentabilidade \& APROBIO, 2015)

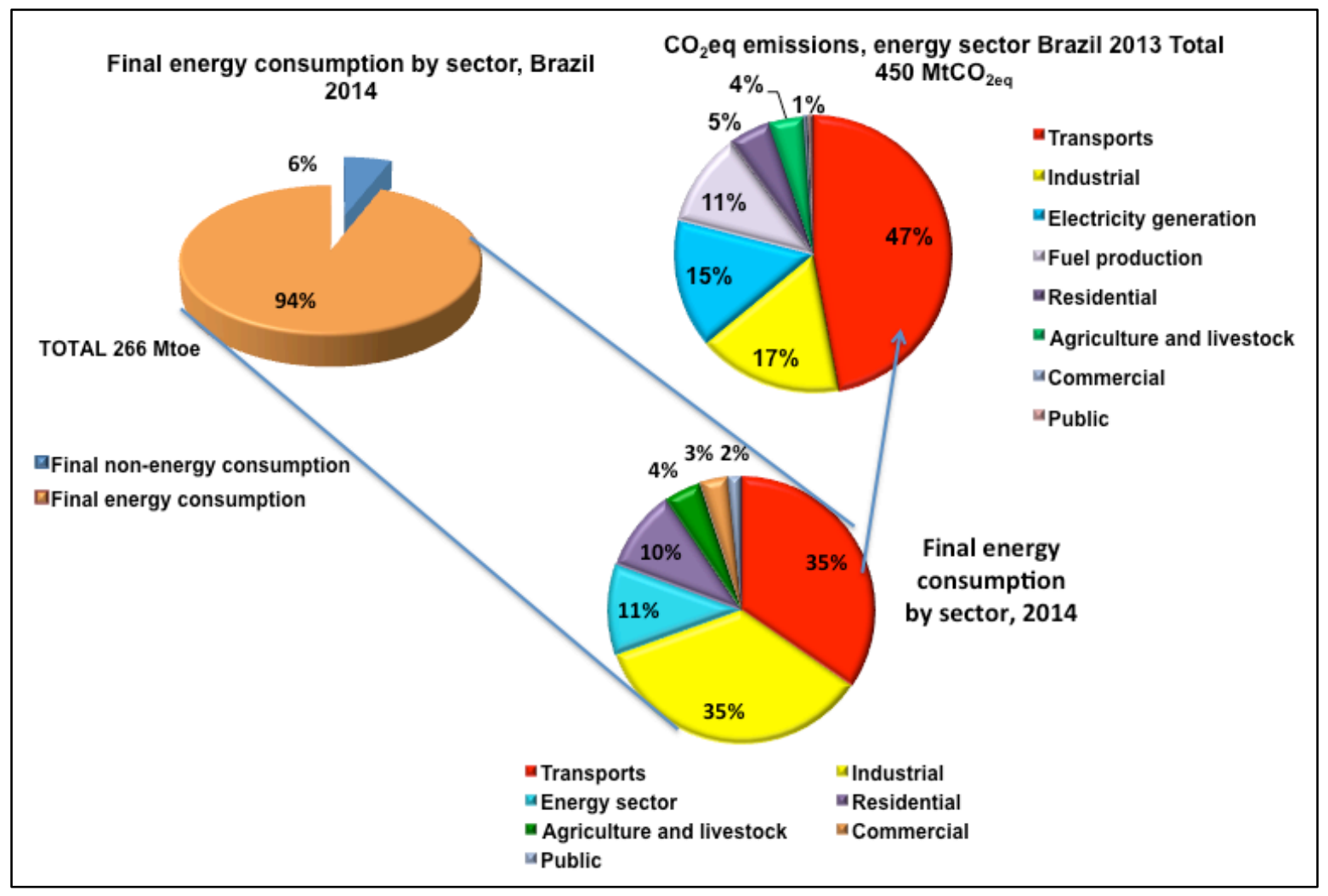

Figure 2 - Final energy consumption by sector, Brazil, 2014

Elaborated by the author based on BEN2014 (Brazil, 2015a) and Emissions Report (OC, 2015).

The Brazilian Energy Decennial Expansion Plan - PDE2024 estimates that in 2024, Brazil will consume 72 million litters of diesel, which will represent a $20 \%$ increasing from 2014 consumption levels. This will obviously increase GHG emissions. The same Plan forecasts that the biodiesel mandate will be $7 \%$, even though the installed capacity of the biodiesel industry (ANP, 2015a) can meet up to a $10 \%$ blend in 2024 , or 7.5 million litters/year. But, in 2015 a proposed legislation (No. 613/2015) was presented to increase the mandate to $10 \%$ in 2016 . It might suggest that plan need to be updated.

Since the energy sector is an important source of GHG emissions; as a subsector, transports should be the key area where the efforts are made to reduce emissions.

\footnotetext{
${ }^{2}$ In Brazilian currency
} 
Especially in Brazil, where the ethanol from sugar cane makes up $15 \%$ of the domestic energy supply, thereby reducing gasoline consumption (Brazil, 2015a), biodiesel is the opportunity to replace mineral diesel. This would decrease emission in the energy sector and contribute to reducing total emissions in Brazil in the coming years. Biodiesel can be blended with diesel used up to $20 \%$ with no need for changes to the engines. Thus, it is an immediate possibility of reducing GHG emissions as well as of other polluting gases and particulates.

Additionally, as agriculture products provide the greatest part of its feedstock for the biodiesel, its production can bring positive impacts for the Brazil economy. Brazil has already good conditions to be the greatest producer and exporter of biodiesel. The country is one of the largest meat and soybean producer, has adequate climate and soil to produce palm tree, and has still land available for agriculture. It means that Brazil can produce three of the four feedstock most used for biodiesel.

There is concern, however, that it may also compete with food for land, and may lead to deforestation. Vianna et al. (2009) suggest the advantages/opportunities and the threats/risks for the biodiesel industry in Brazil (Table 1). They do not distinguish the feedstock used nor the production method because, so far, the biodiesel industry is strongly regulated by Federal Policies, which makes a common business environment for all producers.

Table 1 - Biodiesel industry in Brazil, advantages, opportunities, risks and threats

\begin{tabular}{|c|c|}
\hline Advantages/opportunities & Threats/risks \\
\hline $\begin{array}{l}\text { - Inclusion of family farmers in the agro energy } \\
\text { market; } \\
\text { The distribution logistics of biofuel is already } \\
\text { established; } \\
\text { - It can improve productivity and efficiency in } \\
\text { the supply chain; } \\
\text { - It reduces urban pollution and GHG } \\
\text { emissions; } \\
\text { - The oilseeds can be used to recover } \\
\text { degraded areas; } \\
\text { - It can reduce the vulnerabilities of small } \\
\text { communities for coping with climate changes; } \\
\text { - There is arable land available in Brazil; } \\
\text { There is an enhancement of the by-products } \\
\text { and value-added to commodities such as } \\
\text { soybeans, palm, cotton and meat, etc.; } \\
\text { - The installed capacity of the industry is much } \\
\text { higher than production; } \\
\text { - It would be possible to decrease diesel and oil } \\
\text { imports }\end{array}$ & $\begin{array}{l}\text { - Threats to food security and increased } \\
\text { deforestation; } \\
\text { - Ownership by corporate monoculture, } \\
\text { missing the opportunity for social inclusion; } \\
\text { - Lack of consistent long-term policies; } \\
\text { - Not be competitive and make room for } \\
\text { importation; } \\
\text { Be affected by the deep sea oil production } \\
\text { (pre-salt reserves) and new technologies of } \\
\text { production of oil and gas from shale; } \\
\text { - Inadequacy to the international certification } \\
\text { systems; } \\
\text { - Conflicts with the petroleum industry; } \\
\text { - Changes in European Directives concerning } \\
\text { the replacement of fossil fuels with } \\
\text { renewables; } \\
\text { Persistence of the economic crisis in the } \\
\text { euro zone, which would change the targets } \\
\text { and the policies regarding the replacement of } \\
\text { the oil by renewable sources }\end{array}$ \\
\hline
\end{tabular}

Source: adapted from (Vianna, Wehrmann, \& Duarte, 2009) 
Summing up, biodiesel is an opportunity to help mitigate GHG emissions, increase social inclusion, and save money. Nevertheless, in order to avoid the threats and reduce the risks, the replacement of diesel with sustainable and efficient production requires many variables with a long-term perspective. By sustainable, it is understood that the production considers a balance between the eight sustainable dimensions of Sachs, namely, territoriality, culture, international and national politics, economy, social, environment and ecology (Sachs, 2002). In such a complex situation, which is full of uncertainties regarding future, building prospective scenarios can help to identify and organize the perceptions and possibilities for future decision-making, since scenarios can be seen as a disciplined methodology for imagining possible futures (Shoemaker, 1995) and a tool for ordering one's perceptions about alternative future environments (Schwartz, 1996)

Several studies have proposed scenarios for fossil fuels, while others are concerned with Life cycle analysis - LCA (Jolliet, Saadé, \& Creattaz, 2005) where energy and carbon balances are completed for various biodiesel feedstock; business models of production analysis (family farming, business, major conglomerates) or even the impact of increased biofuel production on food production and the biodiesel contribution to energy security.

There are few studies that explore the future of biodiesel in Brazil. Sousa, built prospective scenarios for biodiesel production for 2020, using Grumbach methods (Marcial \& Grumbach, 2008; Sousa, 2013). The methods include software that creates events based on the responses of the experts about the probabilities of the events. As a result, scenarios are chosen based on the assigned probabilities, therefore each scenario has different chance for this occurrence (Sousa, 2013). Vaccaro et al. (2010) worked on prospective scenarios in the State of Rio Grande do Sul, based on the Systems Thinking and Scenario Planning (STSP). It takes in account events, patterns of behaviour, systemic structures and mental models. A group for people evaluate the variables identified to choose the driving forces and uncertainties. Then the scenarios are built based on two axes of the uncertainties: 'Effectiveness of public policies for the biodiesel chain in RS and Price of raw materials for production of biodiesel. As a combination of these uncertainties, four scenarios were built for the biodiesel industry in the state: competitive challenge, danger, better days will come, and growth and development (Vaccaro et al., 2010). In such set of scenarios, the biodiesel industry in the State depends strongly on public policies to be viable and sustainable (Vaccaro et al., 2010). This method has an advantage of combining qualitative and quantitative approach, but take a lot of time in meetings with the specialists, which can render impracticable on a national scale where the experts are spread all over the country. 
Sousa's work presents scenarios for 2020 but did not include sustainable dimensions; while Vaccaro et al.'s work was limited to one Brazilian state. There are no studies about the possible future of biodiesel in the country as a whole that includes the sustainable dimensions of Sachs.

\subsection{THE PROBLEM}

The aspects listed on Table 1 can be classified into the Sach's dimensions of sustainability in order to organize the perceptions about the future. Considering that some of them are likely to be correlated, it is necessary to know their relationship is necessary to assess the impacts on the future of biodiesel industry.

Also, it is very important to define the horizon time. The Brazilian Government's energy plans include the Decennial Expansion plan for 2024, PDE2024, and the National Plan for 2030, PNE 2030. The newest Agriculture Outlook also has 2024 as the final year for its projections. Thus, a time horizon for the biodiesel scenarios included in this research should be no more than 2030, thereby being coherent with PNE 2030 as well as being relevant for the 2024 plans.

Therefore, the gap that this research aims to fill is to know the possibilities of producing biodiesel in Brazil, by 2030, considering the sustainable dimensions. The research question that comes out of this context is: what are the possibilities for producing biodiesel in Brazil, by 2030 , considering the sustainability dimensions?

\subsection{OBJECTIVE}

Answering this question, the objective of this work is to study alternatives to the biodiesel industry in Brazil, by 2030 that include Sachs' sustainable dimensions, through the development of scenarios.

\subsubsection{Secondary Objectives}

To support the main objective, the following secondary objectives are proposed:

I. Identify and evaluate the elements / forces / stakeholders that can affect the future of the biodiesel industry;

II. Build a scenario methodology that includes the following aspects of sustainability: environmental, cultural, social, territorial, national political, international political, technological, and economic;

III. Develop future scenarios for Brazilian biodiesel industry for 2030 with the dimensions of sustainability based on the methodology developed in items I and II. 


\subsection{THEORETICAL FRAMEWORK AND DELIMITATION OF THE WORK}

The basic assumption in this work is that the future can be built. It means that the scenarios will be developed based on trends but also on the perceptions of the people who can make decisions to change the future. Therefore, this has an implication in the choice of the methodology. The Intuitive Logic School (ILS) of scenario was chosen due to several reasons: because it depends on the perception of the people without despising trends; it allows the integration of the sustainability dimensions of Sachs, and the development of the storylines and testing with virtual methods. Moreover, the ILS has been the most common method used to develop energy scenarios. The details of this choice and the theoretical base of the scenario methodology are detailed in item 1.7 Methodology, and chapter 2- Basic literature review.

Although the proposed objective is limited to the Brazilian biodiesel industry, aspects related to international environment concerns will be part of the analysis, because the feedstock are global commodities. Carbon emissions and land use change also have an international dimension.

Part of the research is based on data obtained through official Government sources. Other part of the research is based on stakeholders' perceptions. So, one would expect the results to vary.

The final scenario storylines were evaluated in a Delphi survey. The ideal situation is to complete as many rounds as necessary to reach a consensus. However, due to the time limitation imposed on this research project, the number of rounds was limited to two, which may not be sufficient for reaching a reasonable level of consensus.

Finally, in order to monitoring the set of scenarios, it would be necessary to build an environmental scanning system. The system was not proposed here, once it was out of the scope of the work.

\subsection{CONTRIBUTION}

The main contribution is the four scenarios for biodiesel industry in Brazil, by 2030, considering the sustainability dimensions of Sachs. As underlying results of this work, other contributions were added. First, it was the identification and evaluation of elements, forces and stakeholders that can affect the biodiesel future. Second, a quantitative approach to find out which feedstock could be used considering the current (2013) land use in Brazil. Third, three new methodological approaches for scenarios building and its practical application were also developed. They are: the identification of dimensions of uncertainty as a framework for mental maps; the application of Sachs's dimensions of sustainability to enlarge the mental maps; and finally a systematic way to develop scenarios storylines. 


\subsection{THESIS ORGANIZATION}

Chapter 1 contains the introductory context, the research question, the objectives of the work, and the methodological aspects of the work. In chapter 2, a literature review is presented for scenario methods, sustainable dimensions, and biodiesel production. Chapter 3 depicts the development of the steps taken to accomplish the objectives. It was done in the format of research article manuscripts for each theme that was necessary to develop. The formats of the sections $3.1,3.2$ and 3.3 have introduction, literature review, methods, discussions and conclusion, and references. Chapter 4 is the epilogue, concluding the thesis. It also includes suggestions for future researches.

\subsection{METHODOLOGY}

To reach the objective, the option was to build prospective scenarios for biodiesel industry in Brazil. The thesis was prepared as research article manuscripts, in order to aid in their submission for publication. Therefore, the core development of this thesis was placed in chapter 3 , which contains 3 manuscripts. They are linked to the secondary objectives mentioned in item 1.3.1 as it is shown on Table 2.

Table 2 - Secondary objectives and manuscripts

\begin{tabular}{|c|c|}
\hline Secondary objectives & Manuscripts \\
\hline $\begin{array}{l}\text { I. Identify and evaluate the elements / } \\
\text { forces / stakeholders that can affect the } \\
\text { future of the biodiesel industry }\end{array}$ & $\begin{array}{l}\text { The choice of feedstocks for producing biodiesel: a case } \\
\text { of Brazil. Chapter } 3 \text {, section } 3.1 \\
\text { Authors: Dias, Maria Amelia de Paula; Bentsen Niclas } \\
\text { and Felby, Claus. } \\
\text { Submitted to Renewable \& Sustainable Reviews, in } \\
\text { November, } 11^{\text {th }}, 2015\end{array}$ \\
\hline $\begin{array}{l}\text { II. Build a scenario methodology that } \\
\text { includes the following aspects of } \\
\text { sustainability: environmental, institutional, } \\
\text { cultural, demographic, social and } \\
\text { territorial, beyond the political, } \\
\text { technological, economic }\end{array}$ & $\begin{array}{l}\text { Sustainability in the prospective scenarios methods: a } \\
\text { practical application of scenarios for biodiesel in Brazil, for } \\
\text { 2030. Chapter } 3 \text {, section } 3.2 \\
\text { Authors: Dias, Maria Amélia de Paula; Vianna, João Nildo } \\
\text { de Sousa } \\
\text { Submitted to the Futures journal in January, } 17^{\text {th }}, 2016\end{array}$ \\
\hline $\begin{array}{l}\text { III. Develop future scenarios with the } \\
\text { dimensions of sustainability, based on the } \\
\text { methodology developed in item I }\end{array}$ & $\begin{array}{l}\text { Integrating driving forces into storylines - the case of } \\
\text { scenarios for the biodiesel industry in Brazil, for } 2030 \text {. } \\
\text { Chapter } 3 \text {, section } 3.3 \\
\text { Authors: Dias, Maria Amélia de Paula; Vianna, João Nildo } \\
\text { de Sousa, Claus Felby } \\
\text { Submitted to the Technological Forecasting and social } \\
\text { Change journal in March, } 4^{\text {th }}, 2016\end{array}$ \\
\hline
\end{tabular}

\subsubsection{Classifying the research}

Scenario can be defined as a tool to organize perceptions about alternative future environments in which the consequences of present decisions will unfold (Schwartz, 1996). Building scenarios for the biodiesel industry involves obtaining and organizing perceptions about the future from the main stakeholders involved in the industry. Qualitative research is 
required when working with perceptions of a specific group. Indeed, the objective of the qualitative research may be to solve a problem, to formulate theories or to test theories (Richardson, 2012). To find out how to classify this research this work, it is necessary to consider three aspects:

a) First, it is necessary to explore a problem or a situation. Building scenarios requires an exploration of both the past and current situation of the subject of the scenarios, which in this case is the biodiesel industry;

b) Second, it will be necessary to evaluate whether or not the scenarios methods include the sustainability dimensions of Sachs (Sachs, 2002). If not, it will be necessary to adapt or to propose a new method;

c) Last, to solve the problem of lacking of prospective scenarios for the biodiesel industry in Brazil, for 2030, it will be necessary to obtain the perceptions of the stakeholders about the future of biodiesel industry and to build scenarios.

Taking in account the first aspect, the research is characterized as exploratory, whilst it aims to explore a situation in order to provide criteria and understanding about the problem, to isolate key variables and relationships, and to obtain or develop criteria to approach the future of the biodiesel industry (Gil, 2011; Malhotra, 2001; Selltiz, 1965). However, the methods used - quantitative approach and qualitative surveys to explore possibilities of production and to obtain the perceptions of the stakeholders; and the anthropological concepts utilized for enlarge the scenario method, characterized the work as crossdisciplinary according to Kolchelmans (1979). The present research aims to solve a problem that no discipline in isolation can adequately deal with, by employing methods or techniques of different disciplines, without, however, integrate them or part of them into a new discipline (Kochelmans, 1979).

Summing up, this thesis is exploratory social research that uses a particular form of interdisciplinarity, called cross-disciplinarity.

\subsubsection{Methods applied - Step by step}

For the first item; to explore a problem or a situation, a simulation was done with optimization models. Linear programming models were run to minimize the costs, to minimize land use and to maximize production. All details can be seen in chapter 3 , section 3.1. The second item, the proposition to modify the scenario method with sustainable dimensions is addressed in chapter 3 , section 3.2. To test the methods, an in-depth interview was included in the method procedures. In the third step, the detailed scenarios and their validation, using a Delphi survey, is shown in chapter 3 , the section 3.3. 


\subsubsection{Optimization models: Linear Program}

The objective of this step was to explore all the feedstock possibilities for producing biodiesel, as per their availability in Brazil. The assumption was that different feedstock would have different consequences in terms of land occupied, the distribution of the production, and the social and environmental consequences. The hypotheses for this approach were: there is enough feedstock in each region to meet the own biodiesel consumption; and the regional production can reverse the trend of market supply concentration.

To allocate inputs from different sources to meet a demand, in an optimal way, it is quite usual to use Linear Programming Model (Hillier \& J., 2010). Therefore, three linear programming models were formulated to simulate different options to produce. The idea was to optimize the biodiesel production: minimizing costs and land use, and maximizing the production. The details of this step are described in the chapter 3 , section 3.1 , item methodology.

\subsubsection{In-depth interview}

In order to obtain the perception of the main market stakeholders, an in-depth interview was conducted. The interview technique fits very well as a method to obtain information about what people know, believe, expect, feel, wish, and intent to do (Selltiz, 1965).

The questionnaire was semi-structured, where the interviewed subjects or panellists were motivated to think about the influence of Sachs dimensions of sustainability, namely social, cultural, ecological, environmental, territorial, economic, National political, International political, and technology, on the future of the biodiesel industry. The interview details can be found in the chapter 3 , section 3.2 , and sub-item methodology.

\subsubsection{Delphi survey}

The Delphi survey method was widely used by the United States during the Cold War years, but its use had only been popularized in the late 1960s, by the Rand Corporation employees- Ted Gordon, Dakey Normal and Olaf Helmer (Godet, 2010). Having been widely used for the development of scenarios, the technique's name originated from the idea of the Delphos Greek oracle, but it is not a tool to predict the future. In fact, it is described as a process of communication (Stitt-Gohdes \& Crews, 2004), aiming to achieve a convergence of opinion and consensus building about real issues (Helmer, 1967; Hsu \& Sandford, 2007), where there is uncertainty or lack of empirical evidence (Powel, 2003). The procedure was built to generate anonymous debates and capture the collective intelligence. Even when there is no consensus or no condition to continue with the rounds until consensus is 
achieved, Delphi serves to crystallize different positions on the issue, showing different interpretations of the same data or revealing different schools of thought (Helmer, 1967).

The key features of the Delphi are the panel size and qualifications of the panellists. Their success relies on selecting the right people, in terms of representability, i.e. on the qualities of the experts and not on the quantity (Turoff, 1975). The basic principle of Delphi is anonymity. Initially this may lead to a lack of responsibility or precipitated responses (Powel, 2003). But one of the advantages of anonymity is the non-occurrence of events such as: the conviction of the person with the most authoritative opinion, convincing the loudest voice; the reluctance to abandon a position in public, or even be convinced by the voice of the majority (Helmer, 1967). On the other hand, several studies have stated that personal opinions on Delphi still are influenced by the consensus of the majority and there are many suggestions to fix this issue (Bolger, Stranieri, Wright, \& Yearwood, 2011; Bolger \& Wright, 2011; Kennedy, 2004; McCarthy, 1992).

The technique has been applied in different areas, even to get an intuitive judgment about a real issue or to obtain experts judgments on future issues (Bolger et al., 2011; Gordon, 2007; Hsu \& Sandford, 2007; Nowack, Endrikat, \& Guenther, 2011; Stitt-Gohdes \& Crews, 2004). The conclusion of many experiments is that the nature of the variables used in the research can also give different combinations with other techniques.

Scenario methods usually require a workshop in other to develop the storylines. In this work, conciliating the agendas of all stakeholders was not feasible, due to the costs and the deadline of the research. Therefore, the option was to write the storyline scenarios based on the interviews and check the their validity using a Delphi survey, on line.

The details of this work are on the chapter 3 , section 3.3, and sub item methodology.

\subsubsection{Sampling - Target audience}

As a qualitative research, it does not require a large number of elements to be part of the sample. But it does require an intentional sample, choosing main stakeholders in the market.

Having a special regulation, the National biodiesel program for production and use of biodiesel, PNPB, the market environment also includes Government ministries, regulatory agency, dealers, and customers.

Therefore, the target audience for the research was chosen based on the Agroindustrial complex suggested by Castro \& Lima (2010), and adapted to include the beef tallow producers according to Martins et al. (2011). The stakeholders include producers, 
dealers, workers, and organs of government that interferes or contributes on the strategic guidance of the PNPB The latter group included:

- The Ministry of Mines and Energy, MME

- The Ministry of Agriculture, Livestock and food supply, MAPA

- The Ministry of Agrarian Development, MDA

- The Ministry of Science, Technology and Innovation, MCTI

- The Ministry of development, industry and foreign trade, MDIC

- The Coordination of the National Program

- The National agency for petroleum natural gas and biofuels, ANP

- The Brazilian energy research company, EPE

- The Brazilian research company for agriculture and livestock, EMBRAPA.

In addition, the Congressman Representative of the Parliament commission for biodiesel was included. Other people were included in the research, as per the suggestions of the above listed participants. Due to the qualitative aspect of the research, as much as possible, the representatives of the groups were interviewed (Figure 3, pink rectangles). The only group that was not included in the research was the consumers because they are a very large group, without representatives. It could mean to have a quantitative approach for a sample, which is not in the scope of this work. The complete list of the interviewees and panellists can be seen in Annex I.

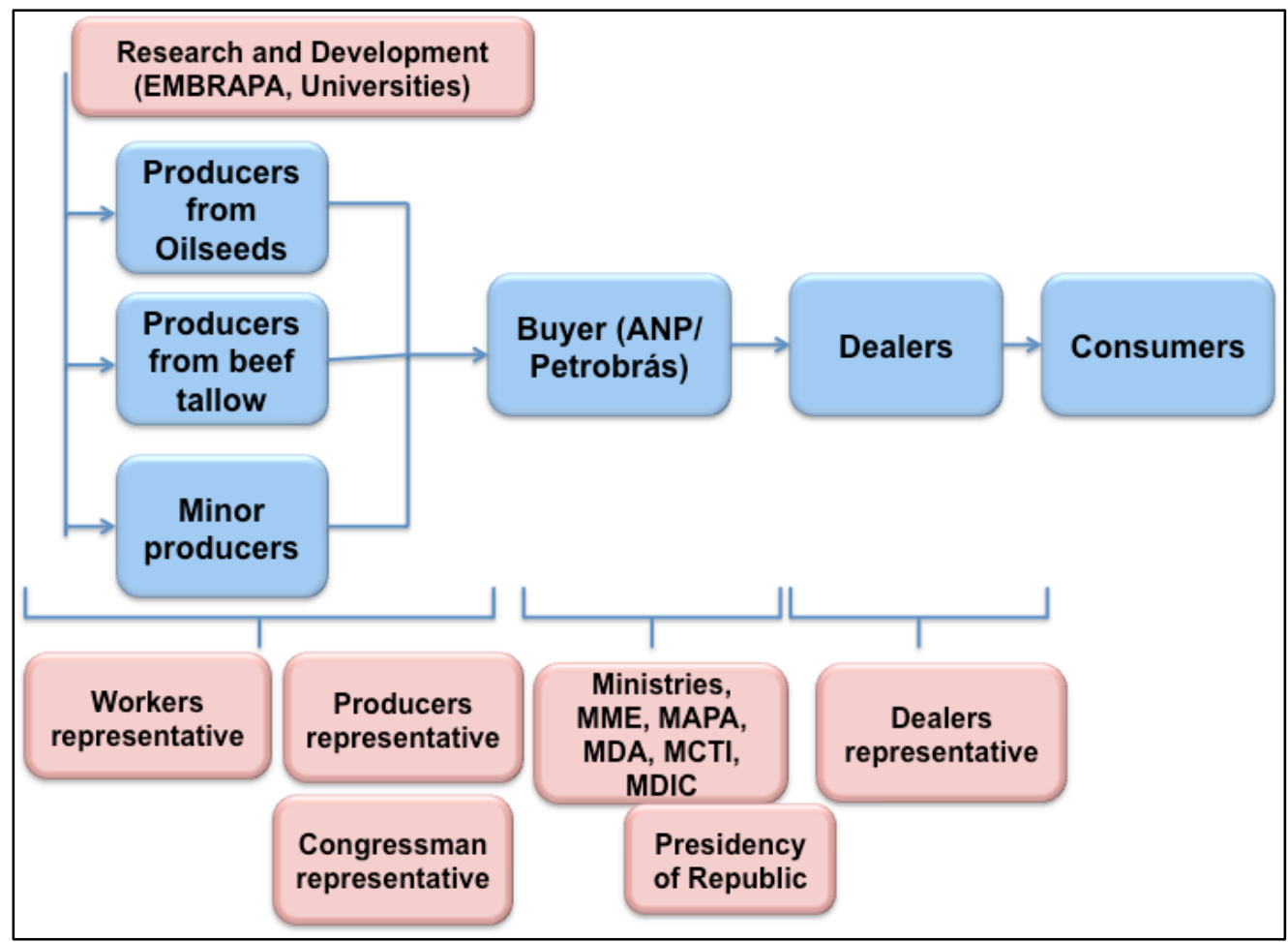

Source: elaborated by the author, based on Castro \& Lima (2010) and Martins et al. (2011)

Figure 3 - Stakeholders of biodiesel industry in Brazil 2015 


\section{BASIC LITERATURE REVIEW}

In this chapter, basic subjects will be treated: biodiesel, the sustainable dimensions of Sachs, and scenarios methods.

\subsection{BIODIESEL}

Biodiesel is a biofuel, miscible with diesel, running as fuel in diesel engines, pure or blended with diesel. Biodiesel can be produced from a variety of oil seeds adapted to diverse climatic conditions in the country (Palacio, Lora, Venturini, \& Olmo, 2010), such as rapeseed, sunflower, soybean, avocado, cotton, peanuts, andiroba, babassú oil, palm oil, sesame, castor, jatropha, flax, macaúba, buriti, turnip and pequi, among others.

Some of the oilseeds used as feedstock are permanent crops like palm oil, macaúba, babassú, buriti, pequis and avocado. Others are temporary crops and can be grown once or twice a year, such as soybean, rapeseed, sunflower, peanuts. Therefore, there are many possibilities. The productivity of each differs according to the percentage of oilseed and oil yield per hectare (Table 3 ).

Table 3 - Oil content and yield of oilseeds for biodiesel

\begin{tabular}{cccc}
\hline Oil Seed & Oil content $(\%)$ & $\begin{array}{c}\text { Months } \\
\text { harvest/year }\end{array}$ & Year yield (ton. oil/ha) \\
\hline Palm Oil / Palm & 22 & 12 & $3,0-6,0$ \\
Coconut & $55-60$ & 12 & $1,3-1,9$ \\
Babassú & 66 & 12 & $0,1-0,3$ \\
Jatropha & $32-35$ & 6 & $1,0-1,4$ \\
Sunflower & $38-48$ & 3 & $0,5-1,5$ \\
Rapseed/Colza & $40-48$ & 3 & $0,5-1,1$ \\
Castor & $45-50$ & 3 & $0,5-1,2$ \\
Peanuts & $40-50$ & 3 & $0,6-1,2$ \\
Turnip & $32-42$ & 3 & $0,3-0,5$ \\
Soybean & $18-23$ & 3 & $0,4-0,6$ \\
\hline \multicolumn{2}{c}{ Source: adapted from (Van Gerpen, Shanks, Prusko, Clementes, \& Knothe, 2004) }
\end{tabular}

Biodiesel can also be produced from waste oils from food preparation applications (i.e. frying) and sewage, as well as animal fats. It can be obtained through three processes: transesterification, esterification, and cracking. The most widely used is the transesterification, where the fresh oil and an alcohol (methanol or ethanol) in the presence of a catalyst result in methyl ester of fatty acid (fat) and glycerine, which is a by-product, removed by decantation. Compare to mineral diesel, biodiesel has the following advantages (Angarita et al., 2008):

- It has no sulphur;

- It has higher solvency, acting as a detergent (which has advantages and disadvantages); 
- Viscosity and density are similar to mineral diesel, but it is necessary to adapt or adjust the injection system of the engine, to replace $100 \%$;

- It has lubricity, reducing wear of nozzles and injection pumps.

Several studies have shown that the use of biodiesel in internal combustion engines substantially reduces emissions of unburned hydrocarbons, carbon monoxide, sulphates, aromatic compounds and particulate matter (Angarita et al., 2008; Pinto, 2005).

\subsubsection{World Market for Biodiesel}

The volatility of the oil prices and uncertainty about supply have led to an increased interest in biofuels (Ravindranath, 2007). The biodiesel production went from nearly 50 thousand barrels in 2003 to almost 500 thousand barrels per day in 2013 (Figure 4). The largest biodiesel producers in 2012 were United States, Germany, Argentina, Brazil and Indonesia (Figure 5). Of these, Argentina and Indonesia have exported regularly. The others are producing to meet their domestic demand.

The forecasts for the global biodiesel market are a $6.6 \%$ annually growth until 2017 (OECD / FAO 2008). The OECD region will account for almost half of global biodiesel demand, while developing countries will account for about $44 \%$ (Ravindranath, 2007). By 2020 , it will possible to have an addition of 200 million $\mathrm{m}^{3}$ of demand, depending on U.S. and European Union (EU) consumers (Vianna, Duarte, \& Wehrmann, 2010). Environmental constraints to crop oilseeds in the EU and the directives regarding the replacement of fossil fuels (EBB, 2013) highlight the potential EU market.

\subsubsection{Contribution of Biodiesel for environmental security}

The environmental benefits of using biodiesel can be seen in two ways. First, it is by the direct reduction of emissions of gaseous and particulate pollutants. Several studies have shown that the use of biodiesel in internal combustion engines substantially reduces emissions of unburned hydrocarbons, carbon monoxide, sulphates, aromatic compounds and particulate matter (Angarita et al., 2008; Pinto, 2005). It also reduces nearly $15 \%$ the $\mathrm{CO}_{2}$ emissions when used in a proportion of up to $20 \%$ (B20), it reduces $\mathrm{SO}_{2}$ emissions compared to conventional diesel and improves lubrication of the engine. Contributing directly to climate change mitigation by reducing greenhouse gas emissions, the elimination of sulphur helps reduce acid rain and directly benefits human health in large centres by reducing urban pollution, which today constitutes a serious problem for public health (OECD, 2014). 


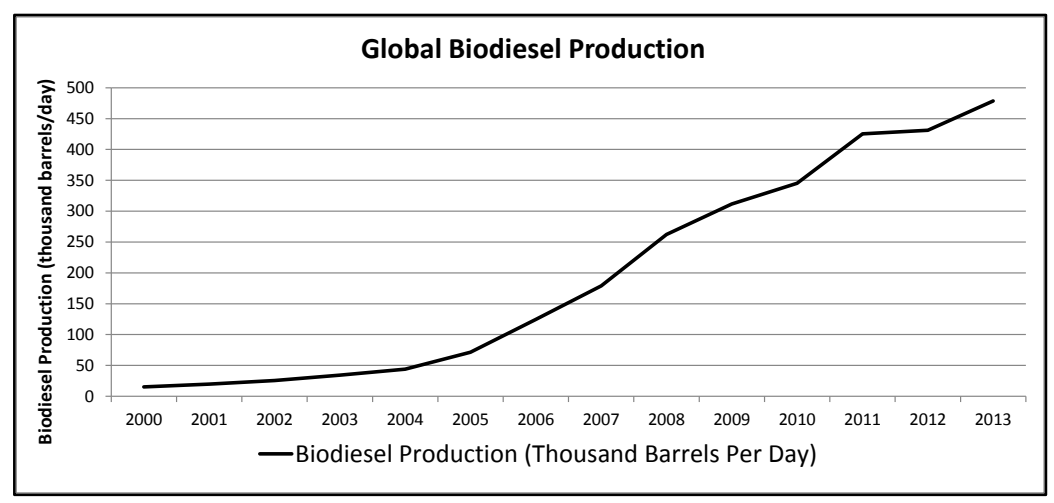

Source: EIA(EIA, 2015a). 2013 was estimated by the author, according to REN21(REN21, 2014)

Figure 4 - World biodiesel production

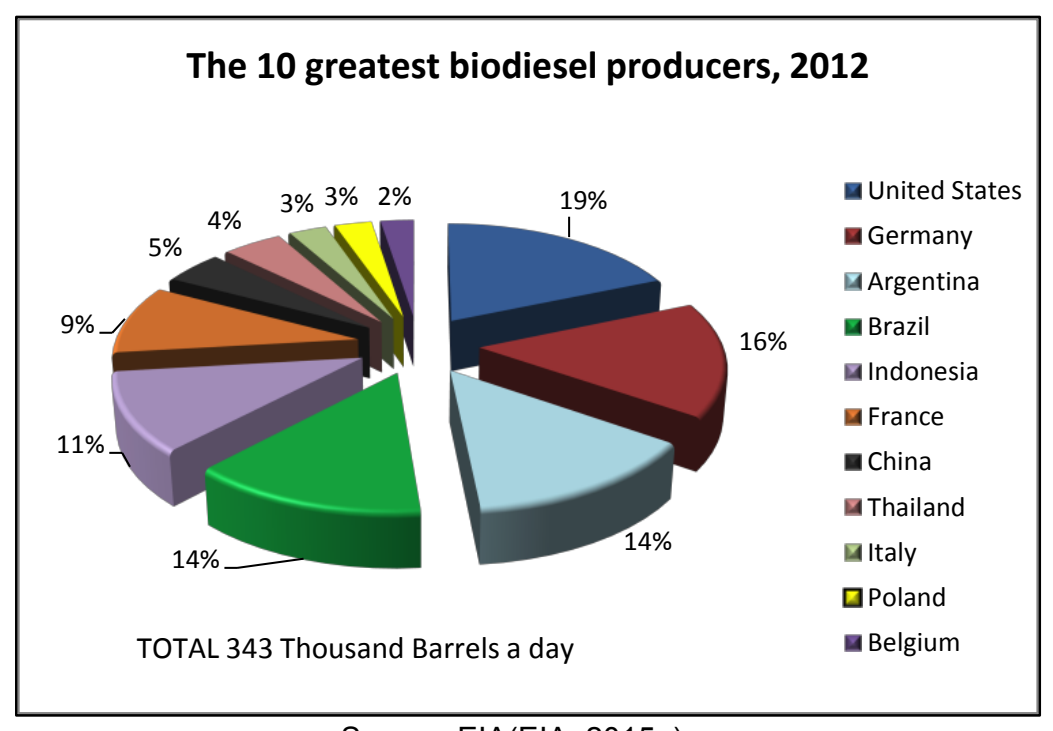

Source: EIA(EIA, 2015a)

Figure 5 - The 10 greatest global biodiesel producers $\mathbf{- 2 0 1 2}$

The second important contribution to the environment is the capture of $\mathrm{CO}_{2}$ through oilseed cultivation. Indeed, the cultivation of oilseeds has shown advantages in the balance of $\mathrm{CO}_{2}$ emissions in most cultures, avoiding GHG emissions between $20 \%$ and $90 \%$ (Ravindranath, 2007). Emissions from the production and processing of biofuels have been well studied with a classical approach to life cycle, considering the various forms of land use. The conclusion of the studies (Fargione, Hill, Tilman, Polasky, \& Hawthorne, 2008; Ravindranath, 2007) shows that when there is conversion of forests or native vegetation, the carbon debt through vegetation removal, may overcome the environmental benefits of using biodiesel. Furthermore, by using agricultural areas where there are permanent crops and permanent pasture to grow oilseeds for biodiesel, can compete with the production of food, fibre or other raw materials, affecting food security and other sectors (Fargione et al., 2008; 
Ravindranath, 2007). In conclusion, biofuels may contribute to the reduction of GHG emissions since the change in land use is avoided or reduced, and appropriate production technologies are employed (Gallagher, 2008; WORLDBANK, 2011). Using degraded land to produce local oilseed is also addressed in chapter 3 , section 3.1

\subsubsection{Competition between Biodiesel and food security in world}

Several papers present an analysis in which the increase in food prices in 2008 coincided with the increased production of biofuels. But the decline, since 2009, in food prices was not related to the biofuels production (Dias, Alves, \& Vianna, 2015; Langevelde \& Meeusen, 2010). The most likely relationship is indirect - the rising price of oil stimulates the production of biofuels and, at the same time, produces an impact on food prices, because the entire economy is based on oil (Langevelde \& Meeusen, 2010). However, based on this indirect correlation, Gallagher (2008) suggested that the goals of replacing fossil fuels by biofuels be cooled in Europe, lest they run the risk of competition between biofuels and food production. In fact, there are projections that the large-scale production of biofuels in the world would not be sustainable in 2020 (Brindraban, Bulte, \& Conijin, 2009).

Nevertheless, it is very important to analyse the feedstock and the land used to produce it. Some feedstock are by-products like cotton oil, soybean oil and rapeseed oil. The most common feedstock used in USA, in 2014 , is soybean (52\%), recycled oils (14\%), rapeseed (11\%) distillers corn oil (10\%), animal fat (10\%), and others (3\%) (EIA, 2015b). Germany, (in 2013) used rapeseed (53\%), palm oil (25\%), soybean (11\%), and coconut (11\%) (UFOP, 2013). Argentina uses mostly soybean (FAO, 2013) and Brazil uses soybean (75\%), beef tallow (17\%) and others (ANP, 2015c). To sum up, in 2012, most of the biodiesel in the world was produced from rapeseed (31\%) and soybean (28\%) (GCEE, 2015) (Figure 6). This means that most biodiesel produced in the world is actually produced from by-products of protein sources. Together, soybean and rapeseed produce $82 \%$ (241 million metric tons) of the protein production in the world, in 2014 (USDA, 2015) (Figure 7). There is no direct competition between producing biodiesel and food in these cases. Other feedstock can grow in marginal or degraded land like Jatropha and castor beans. Those oils are non-edibles, and occupy land that is not used for food. In this case, they do not compete with food for land. Other feedstocks are residues like animal fat and waste cooking oil. Instead of being disposed, these feedstock are used for energy. However, if other oilseeds such as palm oil, which is edible oil, is used as feedstock, then, there may be a competition. On the other hand, the yield of palm oil/ha is much greater than soybean oil or rapeseed oil (Table 3 ). Thus, producing biodiesel from palm oil would save land, when compared to other sources. 
De Fraiture et al. (2008) suggests that the discussion food versus fuels should turn to fuel versus meat (or car versus carnivores) because this amount of protein is mostly to feed animals, no people (Fraiture, Giordano, \& Liao, 2008). Indeed, the discussion about competition for land should include all the resources used in the production of food, feed, biofuel and animals; the effectiveness to convert protein in meat; and all the GHG emissions related (Wassenaar \& Kay, 2008). Moreover, the spacial structure of biofuel production, i.e. where and how it is produced and where it is consumed must be also analysed (Raman \& Mohr, 2014).

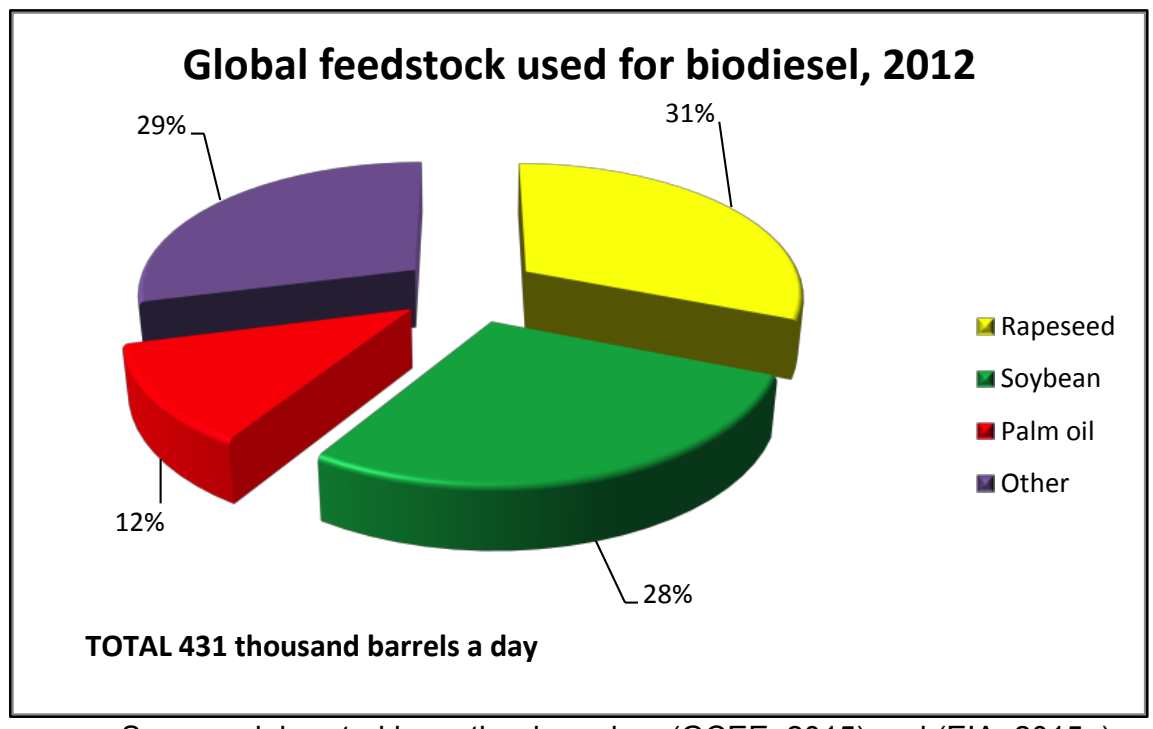

Source: elaborated by author based on (GCEE, 2015) and (EIA, 2015a)

Figure 6 - Global feedstock used for biodiesel, 2012

\section{World protein production $2014 / 15$}

$\begin{array}{lll}\text { Copra } & \text { Cottonseed Fish } \\ \text { Palm Kernel } & \text { P Peanut } \\ \text { S Soybeans } & \text { S Sunflowerseed }\end{array}$

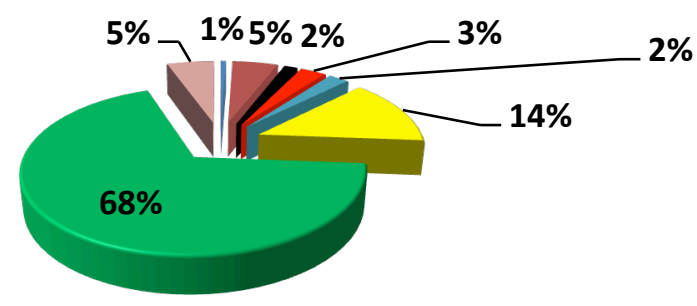

TOTAL: 241 million metric ton 
The creation of a commodity market to ensure the supply and demand for bioenergy in a sustainable way is being studied by the Tripartite TASK 40 of the International Energy Agency group (IEA-task40, 2011). So far, one of the conclusions of the World Energy Outlook report - 2010 (IEA , 2010-1) about biofuels is the inability to develop a unique policy for biodiesel production due to regional and local characteristics already present in each country's agricultural policies.

\subsubsection{Social impacts from biodiesel production}

The social aspect was included in some biodiesel policies in many countries such as Brazil, Zambia, Ghana, Mexico, Peru, and so on. Several studies are evaluating programs for the environmental, social, economic, and governance aspects. The diagnostics show that sometimes government intervention is null or vicious, sometimes inefficient. Some highlighted results show that without care and with no monitoring of program results, biodiesel may be unable to neither make social inclusion nor generate jobs and income for the most vulnerable people. On the contrary, biodiesel is led by big agribusiness companies. As an example, here are some reviews of social aspects of the biodiesel production:

I. Benefits distributed unevenly, conflicts over land, rising prices of land, loss of land in Indonesia and Ghana (Obidzinski, Andriani, Komarudin, \& Andrianto, 2012; Schoneveld, German, \& Nutakor, 2011);

II. Increased social vulnerability for the devastation of native forests, in Indonesia and Ghana (Obidzinski et al., 2012; Schoneveld et al., 2011);

III. The participation of associations of small farmers may be feasible under special conditions to encourage palm oil and jatropha in Peru (Andres Quintero et al., 2012);

IV. There are risk and uncertainty of the industry in Zambia for the small farmers growing jatropha for biodiesel (German, Schoneveld, \& Gumbo, 2011).

In a global perspective, it was expected that developing countries could turn to biodiesel exporters, instead of oil and grains exporters. Raman \& Mohr (2014) mention an attempt to decrease the agriculture subsidies in United Kingdom (UK), in order to deal with the inequalities of Common Agricultural Policy subsidies, which affect the capacity of small farmers in Africa to compete in the global market (Plesch, Austin, Grant, \& Sullivan, 2006). However, as already mentioned, except for Brazil, with ethanol, Argentina and Indonesia with biodiesel, the developing countries are not exporting biofuel at all.

\subsubsection{Brazilian Biodiesel Market}

In January 2005, biodiesel was inserted in the Brazilian national energy matrix with the Law 11,097 of 2005 that defined the mandate of $2 \%$ biodiesel in diesel fuel by 2008 , and 5 
$\%$ in 2013. However, by January $1^{\text {st }}, 2010$, biodiesel began to be added to diesel fuel already in the proportion of $5 \%$, according to Resolution of National Petroleum Council - CNPE \# 6 of $16 / 09 / 2009$. In July, 2014, the mandate was raised to $6 \%$. In November of the same year, it was elevated to $7 \%$. One year after; December 2015, there is a proposition in the Brazilian Congress, to raise the mandate to $10 \%$. The Mines and Energy Ministry authorizes the raise of voluntary use of biodiesel in November, 2015 (Brazil, 2015d).

Brazil is amongst the largest producers and consumers of biodiesel in the world with an annual production in 2014 of 3.4 million $\mathrm{m}^{3}$ and an installed capacity in 2015 about 20.4 thousand $\mathrm{m}^{3} /$ day, or 7.3 million $\mathrm{m}^{3}$ /year (ANP, 2015c). There are fifty-five (55) producing plants in the country, authorized by the ANP. Two new biodiesel plants authorized for construction and capacity expansion will increase the capacity in 885 cubic meters a day. The total can reach 7.7 million $\mathrm{m}^{3} / y$ ear (nominal production capacity per year). This ensures a mandate of 12\%, based on 2014 figures (ANP, 2015a). Indeed, Brazil has good opportunities to have an important role in the bioenergy market, producing clean energy as well as producing inexpensive food, because of its natural resources endowment, advanced agricultural technology, and the proved capacity to compete internationally in major commodity markets (G.S.C Barros et al., 2015).

\subsubsection{Biodiesel production chain in Brazil from vegetable oils}

The agro-industrial complex, AIC, of the biodiesel in Brazil includes a productive chain and processes (Castro \& Lima, 2010). Figure 8 can generically represent the AIC of biodiesel in Brazil. The pink boxes influence or are influenced indirectly by the chain. For each feedstock, there are specific variations. Since the industry is still new, and it is part of energy supply, it is strongly regulated by the government, and Petrobrás, the Brazilian Oil Company exclusively distributes the fuel.

Although soybean is not the most productive oilseed for biodiesel (Table 3), it is the dominant feedstock (Figure 9), due to the strength and organization of its supply chain. The direct consequence is a larger share of the South and Centre-West regions of the country in the biodiesel market (Table 4)

The South and Centre-west regions produce $83 \%$ of the biodiesel in the country, but the greatest consumer is Southeast region (Figure 10). The North and Northeast regions still have land available for the expansion of agriculture. In addition, they have the lowest Human Development Index, HDI ( see Table 5) 


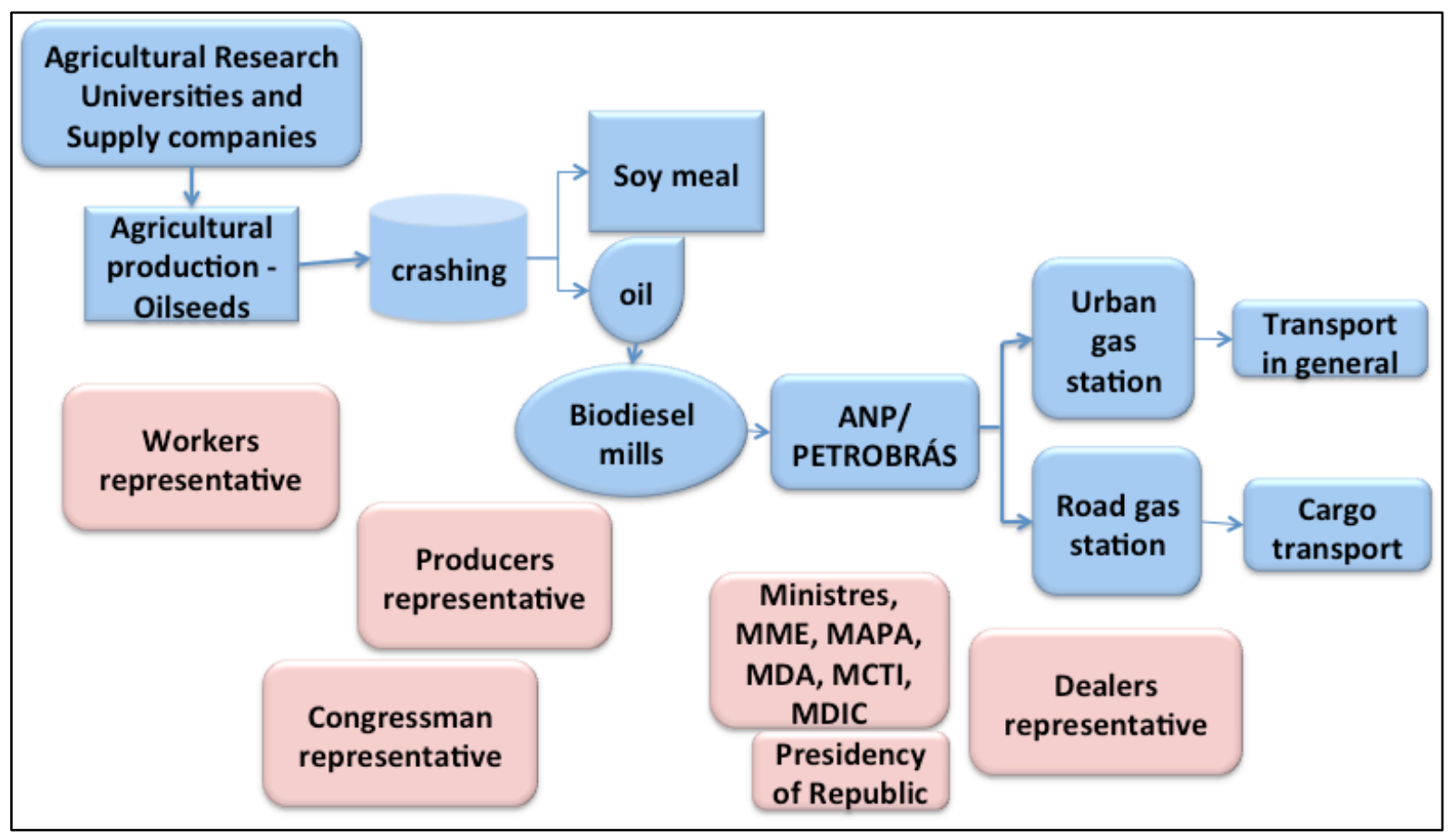

Source: elaborated by the author, based on Castro \& Lima (2010)

Figure 8 - Biodiesel Agro-industrial complex (AIC) from vegetables oil in Brazil

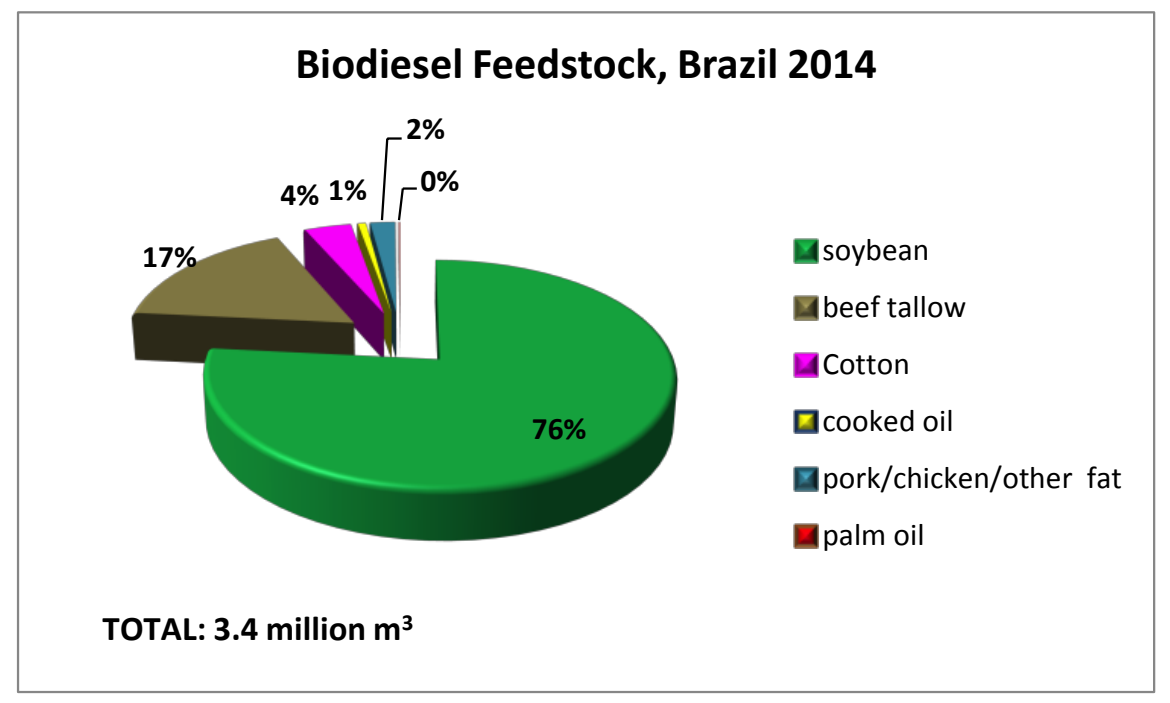

Source: Elaborated by the author, based on (ANP, 2015c)

Figure 9 - Share of oilseed for biodiesel production in 2014 
Table 4- Biodiesel production by Brazilian region (B100, million litters)

\begin{tabular}{crrrrrrrr}
\hline & 2007 & 2008 & 2009 & 2010 & 2011 & 2012 & 2013 & 2014 \\
\hline Brazil & $\mathbf{4 0 4}$ & $\mathbf{1 1 6 7}$ & $\mathbf{1 6 0 8}$ & $\mathbf{2 3 8 6}$ & $\mathbf{2 6 7 3}$ & $\mathbf{2 7 1 7}$ & $\mathbf{2 9 1 7}$ & $\mathbf{3 4 1 9}$ \\
\hline Region & & & & & & & & \\
North & 27 & 16 & 42 & 95 & 103 & 79 & 62 & 11 \\
Northeast & 172 & 126 & 164 & 177 & 176 & 294 & 278 & 307 \\
Centre-West & 126 & 526 & 640 & 1018 & 1037 & 1163 & 1183 & 1472 \\
Southeast & 37 & 186 & 285 & 420 & 379 & 256 & 261 & 271 \\
South & 43 & 313 & 478 & 676 & 977 & 927 & 1132 & 1358 \\
\hline \multicolumn{7}{c}{ Source: Elaborated by the author, based on (ANP, 2015c) }
\end{tabular}

Soybean distribution chain's domination in biodiesel production has important implications. The supply chain is the best structured of all, integrating small, medium and large producers, crushing units and transportation. It produces protein meal that is used as animal feed. The oil is the by-product of the protein meal production is then processed into biodiesel. In the Centre-west region, enterprise production systems dominate the production, with medium and large properties. They have large market share, use bank loans and domestic and international financial support, with a high level of mechanization and productivity. They also have permanent employees with seasonal hiring (Silva, Richetti, Hirakuri, \& Castro, 2010). Smallholders also participate in the chain, which enables the use of tax incentives from the Social Seal, but it is quite clear that large companies dominate.

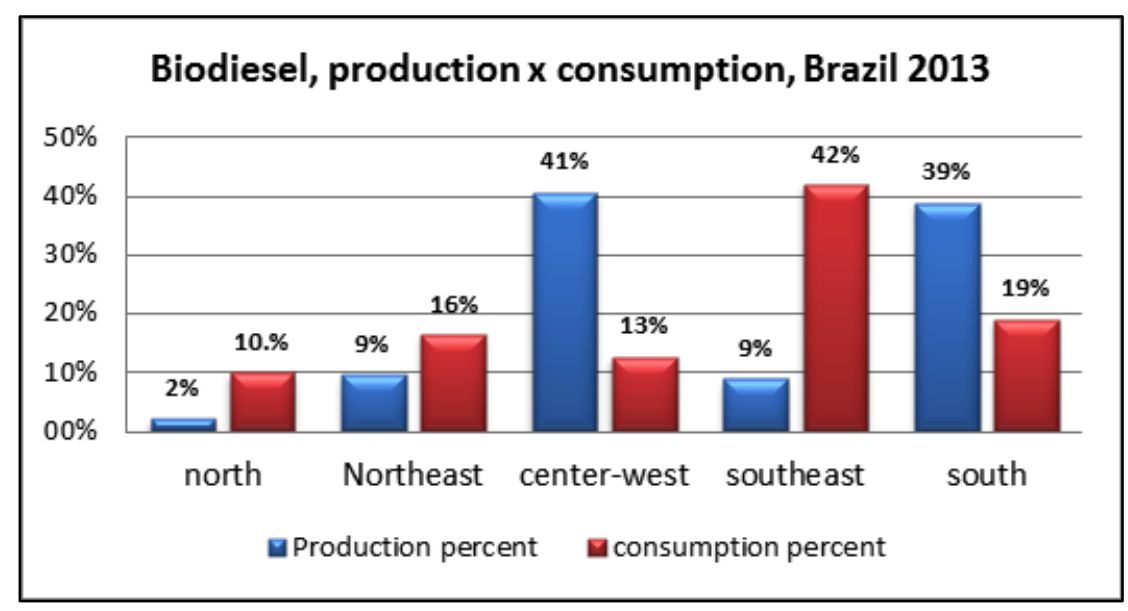

Source: elaborated by authors based on from ANP (P. N. A. ANP, 2014)

Figure 10 - Biodiesel, production x consumption, Brazil 2013 
Table 5 - Regional Human Development Index 2010

\begin{tabular}{cc}
\hline REGION & HDI \\
\hline South & 0.7 \\
Southeast & 0.7 \\
Centre-West & 0.7 \\
North & 0.6 \\
North East & 0.6 \\
Source: elaborated by authors based on from IBGE data (IBGE, 2015a)
\end{tabular}

\subsubsection{Biodiesel production chain in Brazil from beef tallow}

The second most used feedstock for biodiesel production in Brazil is the beef tallow. This biodiesel is quite different from the one produced from oilseed. It has less $\mathrm{NO}_{\mathrm{x}}$ than "veg" biodiesel and sometimes even less than mineral diesel. But the greatest advantage of using beef tallow is high cetane number, which provides a cleaner and faster burning, especially during cold start. As a disadvantage, biodiesel from tallow has more sulphur, which may somewhat restrict its use. But the major drawback is the higher cloud point, which makes it solidify at higher temperatures - about $16^{\circ} \mathrm{C}$ (MILLER-KLEIN, 2006; SANFORD et al., 2009). This restricts its use as B100, especially for export to cold countries. In Brazil, this is not a problem, if the biodiesel from tallow is used in mixtures and in the hotter regions. In Brazil, the production chain of beef tallow derived from the structure of the beef chain system. It is represented in a simplified schematic in Figure 11. The pink boxes do not participate directly in the production but they influence or are influenced indirectly the chain.

Beef tallow is a residue of the beef supply chain and has been traditionally designed for the soap industry. Presently, 950 thousand tons/year of beef tallow is produced in Brazil (Martins, Nachiluk, Bueno, \& Freitas, 2011). It is estimated that currently half of this total is used to produce biodiesel (Dias, Bentsen, \& Felby, 2015). Even though other industries use beef tallow as raw material, there is an expectation that more beef tallow would be used for biodiesel in the coming years. This means 400 million tons of beef tallow resulting in approximately 500 thousand $\mathrm{m}^{3} /$ year of biodiesel. In this case, there is no direct competition with human food industry, but there may be some with the production of soaps and animal feed (Martins et al., 2011). 


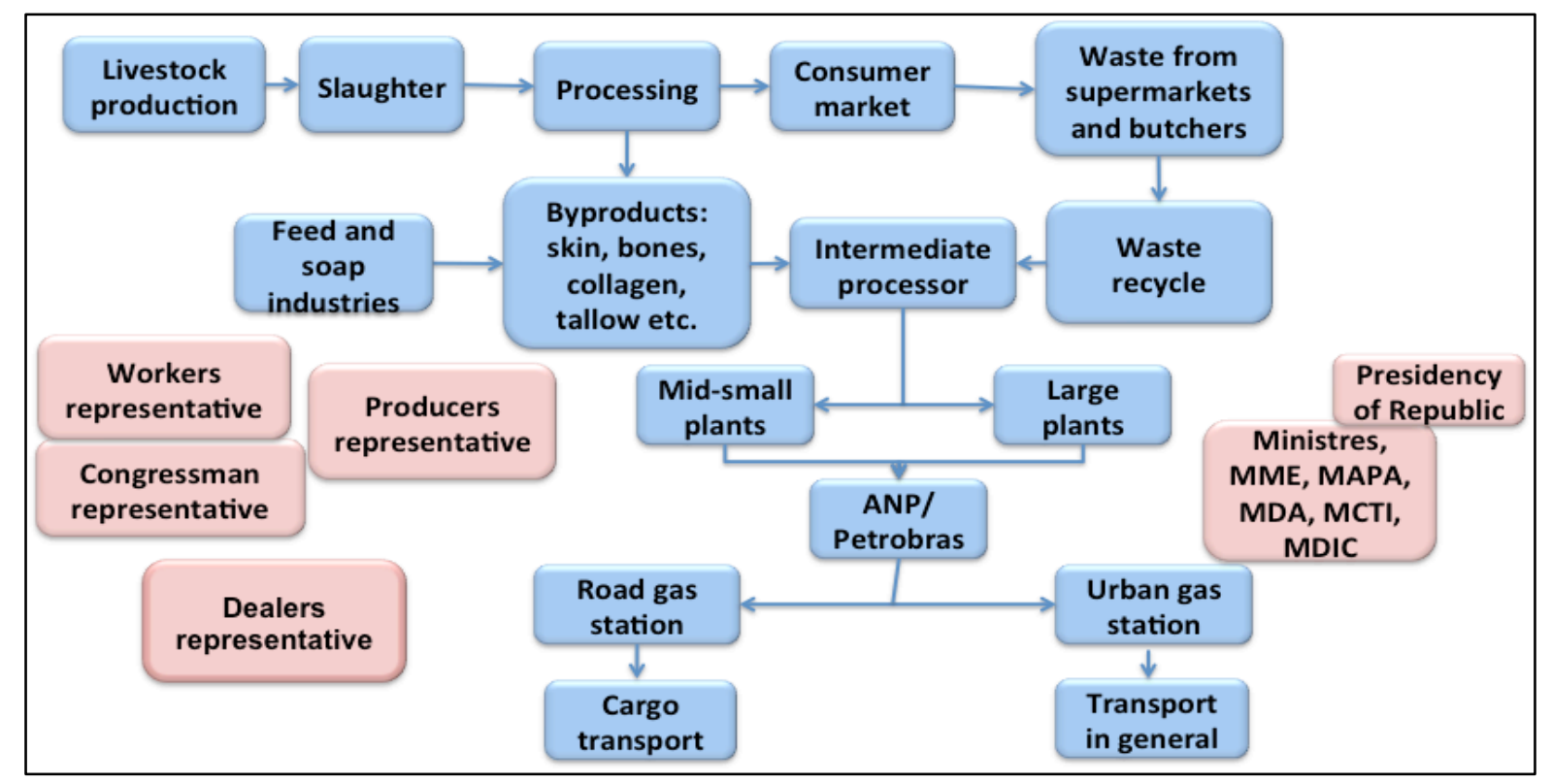

Source: elaborated by the author, based on Martins et al. (2011)

Figure 11 - The agro-industrial complex (AIC) of Biodiesel from beef tallow in Brazil

The production of biodiesel from tallow is more concentrated in São Paulo and some plants that operate with beef tallow are linked to large conglomerates of the livestock industry, such as JBS - Friboi. JBS and Biocapital produced roughly $73 \%$ of the biodiesel from beef tallow, in 2010. It is likely that other beef industries will take the advantage of getting the tallow with low cost, since it has no intermediaries. Until 2015, the biodiesel production from beef tallow did not take advantage of the Social Fuel Seal, but recently, the Seal was modified to include this feedstock.

In addition to beef tallow, there is still a potential of other animal fats like chicken and pork fat. It is estimated that 600 thousand tones/year of fat are available to produce biodiesel. ${ }^{3}$ Also, there is the possibility of using waste cooking oil. It is estimated that in 2014 , 6 billion litres of oil per year ${ }^{4}$ (ABIOVE, 2015) is used for cooking in Brazil. There is no accurate data about how much waste oil results from this consumption, but its use towards biodiesel could be cheaper and can help to solve the disposal problems. Currently, cooking oil has been used in small proportions to produce biodiesel 28 thousand litres in 2013, and 22 in 2014, in Brazil (ANP, 2015c). The regionalization and the diversification of feedstock are addressed on chapter 3 , section 3.1 .

\footnotetext{
${ }^{3}$ Calculated from IBGE data. Available in (IBGE, 2015b)

${ }^{4}$ It refers to soybean oil, that is more than $90 \%$ of the consumption
} 


\subsubsection{Impacts of Brazilian biodiesel production}

\subsubsection{Contribution of Biodiesel for energy security}

Brazil is a continental country with more than eight million square kilometres, and 1.7 million $\mathrm{km}$ of roads (DNIT, 2012). As the transport of goods is primarily by road (CNT, 2015), the consumption of diesel is very important for the country. This dependence represents a logistical and economic vulnerability in case of any supply threat or shortages. For example, a price increase has a direct impact on the price of goods, bringing impacts throughout the economy.

The consumption of diesel and biodiesel in Brazil in 2014 was 60.6 million $\mathrm{m}^{3}$, distributed as follows, which are estimated from data of the National fuel regulator, ANP(ANP, 2015a):

- 11.2 million $\mathrm{m}^{3}$ of imported diesel

- 46 million $\mathrm{m}^{3}$ of diesel produced domestically,

- 3.4 million $\mathrm{m}^{3}$ of biodiesel as a blending of $5 \%$ (until June), $6 \%$ (from June to October), and $7 \%$ (from November) with mineral diesel.

Spending on imports of diesel, in 2014 represented US\$ 8.7 billion (ANP, 2015a). The increase in the biodiesel mandate would reduce or perhaps end the dependence on imports. The possibility of mixing up to $20 \%$ biodiesel would require 12 million $\mathrm{m}^{3}$ of biodiesel. The installed capacity is 7.3 million $\mathrm{m}^{3}$ (ANP, 2015a). Therefore, it would be necessary to increase the capacity by 4.8 million $\mathrm{m}^{3}$. Consequently, imports would be reduced to 2.5 million $\mathrm{m}^{3}$ of diesel (Table 6 ), and could save US $\$ 6.8$ billion, considering 2014 figures. The maximum of biodiesel production in Brazil will be addressed in chapter 3, section 3.1.

However, the price of biodiesel may be a constraint. It should remain compatible with mineral diesel, in order to not increase the prices of transported goods. The possibility of subsidies could be considered, taking into account the existing oil subsidies and foreign exchange savings through decreasing imports in diesel. Therefore, in addition to contributing to foreign exchange savings, the use of biodiesel contributes to the energy security of the country, i.e. with the ability to supply energy to meet the demands of economic growth.

The pre-salt oil reserves in Brazil may produce enough oil and hence diesel to replace all diesel imports. If social and environmental perspectives are not considered, it would be a demotivation for the biodiesel production. The higher the oil price the more viable that for biodiesel. However, in the last year, the oil price barrel went to less than US\$100. However, the biodiesel mandate did not decrease; quite the opposite, it seems to go up. One of the reasons can be the increasing availability of soybean oil, due to the decreasing of Chinese imports (OECD-FAO, 2014) and due to the increase in soybean harvest in Brazil in 2014/15 (CONAB, 2015b). International pressure to reduce GHG emissions, especially after COP21 
meeting, may be another reason. Biodiesel use decreases the $\mathrm{CO}_{2}$ emissions by $15 \%$ compared to diesel, when mixed in a proportion of up to $20 \%$ (B20).

Table 6 - Calculus for the mandate of $20 \%$ in Brazil

\begin{tabular}{|c|c|c|c|c|c|}
\hline \multicolumn{5}{|c|}{ Brazil, 2014 consumption } & \multirow[b]{2}{*}{$\begin{array}{l}\text { Possible saving in } \\
\text { imports / } 2014\end{array}$} \\
\hline & $\begin{array}{l}\mathrm{B} 6 \text { e B7 } \\
\text { million m³ }\end{array}$ & $\begin{array}{l}\text { Import costs, } \\
\text { billion } \\
\text { US \$ }\end{array}$ & $\begin{array}{c}\text { B } 20 \\
\text { million } \mathrm{m}^{3}\end{array}$ & $\begin{array}{l}\text { Import costs, } \\
\text { billion } \\
\text { US \$ }\end{array}$ & \\
\hline $\begin{array}{l}\text { National diesel } \\
\text { Imported }\end{array}$ & 46 & & 46 & & \\
\hline diesel & 11.2 & 8.7 & 2.5 & 1.4 & \\
\hline Biodiesel & 3.4 & & 12 & & \\
\hline TOTALS & 60.6 & 8.7 & 60.6 & 1.4 & US\$ 7.3 billion \\
\hline
\end{tabular}

Source: elaborated by the author, based on ANP - www.anp.gov.br

Regarding mineral diesel, biodiesel has the following disadvantages (Angarita et al., 2008):

- The higher the content of the mixture, the greater the biodegradability, altering the physical and chemical characteristics to the production of visible solids;

- There could be contamination in the presence of water or oxygen, which in turn triggers microbial growth;

- The storage time is a maximum of 30 days. The longer it is stocked, oxidation will occur, as well as water absorption, thereby increasing the viscosity and acid number;

- Changes in temperature and $\mathrm{pH}$ may also promote microbial growth;

- Oxidation may cause an increase in viscosity and the formation of gums (polymer compounds).

- The sediment may result in clogging of filters and injection systems.

\subsubsection{Competition between Biodiesel and food security in Brazil}

There is a fear that the biofuels production requires additional land for the cultivation oilseeds (WORLDBANK, 2011). In Brazil, the main sources of biodiesel are by-products of other production chains, i.e. soybeans and beef tallow, which does not require more land to increase the production. Regarding soybean, for example, it is expected that the production of soybeans in the 2015-2016 harvest will be is around 100 million tons (CONAB, 2015b), which would produce 20 million tons of oil and 22 billion litres of biodiesel. Considering the total consumption of 55 million tons of grains per year (ABIOVE, 2015), there would be still 45 million tons of grains, that could be crushed instead of exported. This, in turn, will result in 9 million tons of oils to produce 10 million $\mathrm{m}^{3}$ of biodiesel oil, which would be enough to increase the mandate up to $16 \%$ (B16), in 2015. There is still the possibility of other 
feedstocks namely, animal fat, waste frying oil, oilseeds that can grow in degraded or marginal land, and so on. So, it is not likely biodiesel production is competing with food for land. The maximum potential to produce biodiesel in Brazil is discussed in section 3.1.

In Brazil, there is still land availability for agriculture, but most of them are in the Amazon region and in the Cerrado, North and Centre-West regions (Sparovek, Barretto, Matsumoto, \& Berndes, 2015). Even though they are not protected areas, it would cause a change in land use. In addition, in Brazil that has one of the largest herds in the world - 200 million heads that occupy 170/200 Mha (IBGE, 2015b), there is a potential do increase the pasture yield and convert pasturelands into arable land. However, as already mentioned in 2.1.1.2, for a complete discussion about land use, it is necessary to analyse the production of food, feed and biofuel together.

\subsubsection{Possibilities of the Biodiesel industry for social inclusion - social label}

As an incentive and organization of biodiesel production, the federal government established the National Program for Production and Use of Biodiesel, PNPB in 2005, focusing on social inclusion and regional development. The main guidelines of PNPB are: implement a sustainable program that promotes social inclusion, guarantee competitive prices, quality and supply; produce biodiesel from different oil seeds strengthening regional potential for the production of raw materials (Garcez \& Vianna, 2009). The Social Fuel Stamp was created with the purpose of promoting the social inclusion of family farmers framed by PRONAF by Decree no. 5297 (12.06.04) and amended on September/2012. The seal provides the reduction of taxes (PIS/COFINS and PASEP), which vary according to the raw material, the region, the commercial incentives and financing (Brazil, 2012c). In 2015, the seal was modified to include biodiesel produced from beef tallow.

Many evaluations of the social results have been made. Examples can be seen as the follows:

a) Social Fuel Seal managed to allow for the inclusion of small soybean farmers in Sorriso, Centre-west region of Brazil. There is evidence that land is being transferred to large farmers and businesses in the same region of the country (Lima, Skutsch, \& Costa, 2011) ;

b) Positive experiences with inclusion of economic gains in plantations intercropped with castor beans production in Northeast Brazil (Janssen \& Rutz, 2011);

c) Domain of large businesses in biodiesel production by soybeans in Brazil, despite the Social Fuel Seal (Janssen \& Rutz, 2011);

d) Employment generation in Brazil by PNPB not yet reached the goal in the production of biodiesel (Rathmann, Szklo, \& Schaeffer, 2012), but some progress has been 
made with palm oil in the northeast, with the use of the Social Fuel Seal (César \& Batalha, 2013).

It is estimated that from 2005 to $2010,1.3$ million jobs (direct and indirect) were created from Biodiesel production (FGV, 2010) in Brazil. In 2014, the number of direct jobs of the industry is estimated 141 thousand by IRENA (IRENA, 2015). If the mandate goes to $20 \%$ in 2020, it is estimated that 532 thousand direct jobs will be created (FGV, 2010).

As of late, the number of small farmers in the Brazilian Biodiesel program is decreasing, from 104 thousand families in 2011 to 73 thousand in 2014, (Brazil/MDA, 2015).

Being part of large conglomerates, both soy and beef tallow do not reflect the priority of the inclusion of small producers in the biodiesel industry, except in the south part of Brazil where there are many small family farmers participating in the biodiesel chain. Social inclusion implies different geographical distributions of oilseed crops and different business models, in which the inclusion of small producers can vary significantly. A complete diagnostics of the Social Fuel Seal may be a subject for future research.

\subsubsection{Human health and the emissions avoided}

From 2005 to 2014, the emissions avoided due to the replacement of biodiesel use in Brazil reached $36.6^{5} \mathrm{MtCO}_{2}$ (Gazzoni, 2012a). The biodiesel mandate was gradually increased from $2 \%$ up to $7 \%$ in 2014 . But the pollution in big cities is still very large and it costs many deaths. It was estimated that in 2015, 4.6 thousand deaths occurred due to air pollution in the São Paulo metropolitan area (São Paulo is the biggest city in Brazil) (Saúdee-Sustentabilidade \& APROBIO, 2015). This figure can reach 56 thousand from 2015 and 2025. However, if the mandate increases to $7 \%$, roughly 1.2 thousand deaths will be avoided. Adopting 20\%, 7.3 thousand deaths can be avoided in this period (Saúde-eSustentabilidade \& APROBIO, 2015). Thus biodiesel use can help to improve life conditions decreasing the amount of particulates in the air, especially in large urban concentrations.

\subsection{SUSTAINABLE DIMENSIONS OF SACHS}

The Stockholm conference in 1972 was the first conference dedicated to environment and represented a first effort to address the global human impact on the environment. The fourth item of the Stockholm declaration indicates that in order to have socio-economic development in developing countries, measures are needed that can mitigate social discrepancies, all the while being concerned about environmental issues (Handl, 2014). The Brundland Report, Our common future, stated that Sustainable development is development that meets the needs of the present without compromising the ability of future generations to

\footnotetext{
${ }^{5}$ Estimated based on Gazzoni,2012
} 
meet their own needs (UN, 1987). After that, in 1994, Elkington coined the triple bottom line, the 3 Ps: profit, people, and planet (Elkington, 1994). The idea was that companies should take in account the $3 \mathrm{Ps}$. One is the traditional measure of corporate profit; the second is to measure how socially responsible an organization should be throughout its operations; and the third the measure of how environmentally responsible it has been (Elkington, 1994).

Nowadays, the concept of sustainable development goes beyond economic development and out of the current market logic. The practical approach of this concept requires that it becomes global concern and an effective solidarity between the North countries (rich) and South countries (poor) to find alternative pathways that are not the repetition of the North hemisphere consumption. Therefore, it is not enough to have just the economic growth as the main driver for strategies and plans. It is necessary to have a more holistic vision to capture other dimensions of the human development and their relationships (Sachs, 2002). Even thought it is quite common to talk about the triple bottom line of sustainability namely, economic, environment and social aspects, Sachs (2002) suggests that those three aspects should be more detailed as follows:

- Territoriality, which includes:

- Relationship between rural and urban sites

- Improving urban environment

- Overcoming inter-regional disparities

- Strategies of environment development for ecologically fragile areas (biodiversity for eco-development)

- Culture, detailed by:

- Tradition and innovation

- National autonomy

- Self-confidence / openness to the world

- International politics:

- Prevention of war, guarantee of the peace, promotion of international cooperation, north-south co-development

- Effective control of the international financial system and business

- Effective control of the application of the precautionary principle

- Prevention of negative global changes, protection of biodiversity and cultural diversity and management of global heritage

- National politics:

- Democracy and appropriation of universal human rights

- Economics, including minimum conditions of survival for the people involved ; 
- Inter-sectorial balanced economic development

○ food safety

- continue capacity of modernization (production scientific and technological research)

- Sovereign insertion in the world economy

- Social, considering:

○ the future generations welfare,

- social homogeneity

$\circ$ income distribution

○ full employment, decent quality of life

- equal access to resources and social services

- Environmental, respecting and enhancing the capacity of self-regeneration;

- Ecologic, including:

- Preservation

- Limitation of the use of non-renewable resources

Notice that each of these dimensions would require proper definitions. However, for the general application in this work, it will be sufficient to have this broad framework. How they are going to be utilized is addressed in section 3.2.

\subsection{SCENARIOS}

The word scenario, representing something in the future, can be used with different meanings, depending on how people understand the future. Herman Kahn defined scenario as hypothetical sequences of events constructed for the purpose of focusing attention on causal processes and decision points (Kahn \& Wierner, 1967). Scenario can also be a description of a possible future, or a way of representing the future in order to clarify present actions to lead them to the desirable futures (Durance \& Godet, 2010). Schwartz defines scenario as a tool to organize perceptions of the people about alternative future environments in which the consequences of your decision will happen (Schwartz, 1996).

From these definitions, emerges a difference in perception of what the future is; is there something that exists and it is necessary to perceive it; or if it is something to be built.

\subsubsection{Types of Future}

The perception of what the future is will lead to the possibilities for future. These, in your turn, will determine the type of technique used to develop scenarios. 


\section{a) When the future is pre-determined}

The future is seen by some as something that is already pre-determined, with a close causal relationship between present and future. It is a mechanistic view of the universe; once the initial conditions are given, the future is determined. An underlying hypothesis that could be considered in this case is: if the future is pre-determined, there may be people able to predict the future. In fact, some methods of scenario development can also be based on the judgment of a visionary - one genius forecasting or a preview of a group (Kahn \& Wierner, $1967)$ to create the images. Thus, the future can be understood if the conditions of the present are extrapolated with predictions. They can be made through statistical extrapolation of variables, or a more sophisticated way using simulation models, in order to answer the question: what will happen? (Börjeson, Höjer, Dreborg, Ekvall, \& Finnveden, 2006). According to Börjeson et al. (Börjeson et al., 2006), predictive scenarios can be subdivided into: forecasts, which comes from extrapolations of current trends and what-if scenarios ${ }^{6}$ that uses simulation models to identify consequences of changes in the initial conditions.

British Petroleum elaborated long run projections for energy indicators in their BP energy Outlooks based on this thinking of pre-determined future. It is clear that they use quantitative projections (BP Energy Outlook 2035, 2015). The International Energy Agency, IEA, uses the model ETP that belongs to the MARKAL family of bottom-up modelling tools and uses optimisation to identify least-cost mixes of energy technologies and fuels to meet the demand for energy services, given constraints such as the availability of natural resources (IEA, 2011). The IEA produces annually the World Energy Outlooks that is based on assumptions of changing in world energy policies and also in quantitative projections (IEA-International-Energy-Agency, 2015). Axelsson et al. (2009) made a proposition of a tool to create energy market scenarios, and to evaluate the energy related investments in energy intensive industrial processes (Axelsson, Harvey, \& Berntsson, 2009). The Colombian energy plan also uses projections based on demand and supply 2025 (Perdomo, 2006). The energy scenarios of Denmark, for 2020, 2035 and 2050, use simulation models to project the availability of the different sources of energy (STATEOFGREEN, 2015). Mintzer et al.'s proposition of energy scenario for USA had a complex method call AMIGA - that includes 5 types of economic models, which aggregated results were analysed in workshops to produce 3 scenarios (Mintzer, Leonard, \& Schwartz, 2003). The Brazilian energy scenarios for 2040 , created to analysed the impact of the Brazilian climate scenarios, use Integer programming model to simulate alternatives for energy supply, to balance constraints and the future demand (Brazil, 2014a), using the software MESSAGE (IAEA, 2009; Soares M.C. Borba,

\footnotetext{
${ }^{6}$ This outline was from the referenced author.
} 
Szklo, \& Schaeffer, 2012). The Brazilian National Energy Plan for 2030 also uses simulations and projections to estimate the demand and consumption of all kinds of energy (Brazil/MME/EPE, 2006). The decennial plans of energy, PDE, which are updated more frequently, also are based on quantitative projections (Brazil, 2015c). Pereira Jr. et al. (2008) analyse the sustainable future of energy in Brazil, based on the National Energy Outlook studies for 2030 and using quantitative indicators from IEA (Pereira Jr, Soares, de Oliveira, \& de Queiroz, 2008). Xavier et al. use System Dynamics to quantify the impacts of the Brazilian energy scenarios across social and environment indicators in a dynamic and flexible way, for the State of Minas Gerais, to simulate possible trajectories of energy demand and supply. The model runs in the platform Simulating and Assessing Public Policies of Energy and Climate Change (SAPPE) developed in the Vensim software (Ventana Systems, Inc., Harvard) (Xavier et al., 2013).

Ajanovic \& Hass (2014) investigated the market prospects of biofuels with a time horizon up to 2030, in Brazil, the EU and USA (Ajanovic \& Haas, 2014). They use an economic approach based on a dynamic modelling in which all relevant cost categories of converting feedstock into biofuels - ethanol and biodiesel are included. Their conclusion is, for now, only Brazilian ethanol is cost-effective. Chatterjee et al. (2014) propose a quantitative method to evaluate biodiesel production based on indicators for sustainability factors namely social, environmental and economic. Their work is applied to the current production, not for the future (Chatterjee, Sharma, Mukherjee, \& Kumar, 2014). Acquaye analysed the potential of biofuels contributing to the UK emission reduction targets, using different assumptions as scenarios (Acquaye et al., 2012). Brazilian National Plan for Energy, PNE 2030 has a special chapter dedicated to liquid fuels, where it is possible the find the projections for biodiesel and the other liquid fuels, as well as the results of quantitative methods and assumptions about political decisions (Brazil, 2007). Rovere et al. (2011) made quantitative projections, based on assumptions, to analyse the sustainability of the biofuel programs, stating that biofuels in Brazil is the opportunity to promote rural development due to its comparative advantages, which includes largest land availability of cropland (Rovere, Pereira, \& Simões, 2011). Santos used the economic model of general balance to analyse the impacts of the replacement of the fossil fuel by biofuels, from 2010 to 2030, in Brazil. He concludes that increasing the use of biofuel will impact positively on the economy (Santos, 2013). Leiras et al. also make an economic evaluation of the biodiesel supply chain in Brazil. Based on 204 economic simulation scenarios they consider biodiesel production to be feasible (Leiras, Hamacher, \& Scavarda, 2008). 


\section{b) When the future just emerges}

Future may also be something emerging and completely indeterminate. Emergence is the appearance of an unpredictable or incalculable behaviour, which results from the interaction of many simple components, but cannot be the result of the knowledge about how each system component behaves alone. This view makes up the evolutionary paradigm (Van Der Heijden, 2005), where anything can happen anytime. It relies on complexity theory, where the system behaviour can become indeterminate and emergent (Van Der Heijden, 2005). Therefore, it is impossible to predict and scenario and plans are useless. It would be better to be prepared to be flexible, to learn and survive, because the only thing possible to do is to react to events.

\section{c) When the future can be built}

The future may be something that can be built. In this case the questions to be answered are: what do we want to happen? And what can happen if...? (Börjeson et al., 2006). The future can be built or induced through public policies, for example. Even though there are some trends that will be consolidated in the future, it is possible to change them or cause events and changes. Nevertheless, part of this future can be uncertain and completely unpredictable, as much as we do something about it. So, the future is neither exactly predetermined nor completely chaotic. It is possible to have strategies for the future, since they incorporate feedback mechanisms to be adaptable. It is characteristic of the procedural paradigm (Van Der Heijden, 2005), where the process of thinking about future can be more important than having the right images of the future (Schwartz, 1996). The construction process can create a better society, which brings a humanist thought (Inayatulaah, 1993). In this case, both normative and exploratory images may emerge, according to the classification of Börjeson et al. (2006).

Exploratory scenarios are related to past and present trends that lead to a probable future (Durance \& Godet, 2010), being also called descriptive (Amer, Daim, \& Jetter, 2013). While exploring past trends, they resemble the pre-determined scenarios. However, the methods may incorporate strategies to change trends, which give them a constructive character of the future. They can explore the conditions or situations that are likely to happen, but under a long-term perspective (Börjeson et al., 2006). They are subdivided into external scenarios - which focus on factors that are beyond the control of the relevant stakeholders; and strategic scenarios, which incorporate political measures under user control, describing possible consequences of strategic decisions (Börjeson et al., 2006).

Normative scenarios focus on desirable future situations and how they can be achieved (Börjeson et al., 2006; Durance \& Godet, 2010). Subdivided into preserving scenarios, where 
the purpose is to know how a goal can be achieved efficiently, often using optimizing modelling; and transforming scenarios used as back-casting. Both presuppose a future image in order to analyse it retrospectively to find the means to achieve this picture (Börjeson et al., 2006).

Exploratory scenarios are independent of human values, whereas the normative are the expression of these values (Durance \& Godet, 2010). Normative scenarios are the future that people want. Exploratory is the future that explores past trends, but incorporate strategies to change the trends (Börjeson et al., 2006). The set of images in the normative and exploratory scenarios may be similar or contrasting, depending on the trends considered.

Based on the assumption that future can be built, the Millennium Project of the United Nations Development Programme (UNDP) developed an exploratory energy scenarios for 2020, as a combination of quantitative projections, uncertainties matrix, and an on-line Delphi survey (Gordon, 2007). Shell, a very known organization due of the pioneering in scenarios methodologies, still uses normative and explorative scenarios, supporting by its own methodology TANIA, which means there are no ideal answers (SHELL, 2008). WWF made propositions for renewable energy by 2050 , based on a normative scenarios, where given an ideal situation, a back-casting is made in order to show the way to reach the scenarios (WWF-Ecofys, 2011). World Energy Council scenarios are based on drivers, critical uncertainties that results in storylines, after interviews and workshops with experts. Such global energy scenarios were designed to address the energy trilemma ${ }^{7}$ (WEC, 2015b) of achieving environmental sustainability, energy security, and energy equity (WEC, 2013). They applied the same method to build New Zealand energy scenarios for 2050 (WEC, 2015a). The trilemma was also the basis for the Argentinian Energy Scenarios for 2030 (Fernández, 2012). The Argentinian document also uses some costs parameters and the software LEAD (SEI-Stockholm-Environment-Institute, 2015). The energy scenarios for the UK, uses two axes called prosperity and green ambition to design four scenarios, which are analysed considering 2 times horizons: 2020 and 2030. They also make some projections for these years for each of the four scenarios (Nationalgrid, 2015). Clean energy scenarios for Greece were built also based on uncertainties - economic growth, technological development, fuel cost, public acceptance and international climate policies. They were summarized on two axes: economic growth and technological advances as framework for the scenarios storylines (Roinioti, Koroneos, \& Wangensteen, 2012) then typical

\footnotetext{
${ }^{7}$ Energy trilemma: energy security, environmental sustainability and energy equity derives from the triple bottom line of sustainability: economically feasible, socially just and environmentally correct.
} 
normative/explorative scenarios were based on $\mathrm{GBN}^{8}$ matrix (Bishop, Hines, \& Collins, 2007).

Sousa, built prospective scenarios for biodiesel production for 2020, using Grumbach methods (Sousa, 2013). The methods include software that creates events based on the answers of the experts. It is not clear how the events area created and how the probabilities are calculated. As a result, scenarios are chosen based on the assigned probabilities, so each scenario has different chance occurring (Sousa, 2013). Vaccaro et al. (Vaccaro et al., 2010) worked on prospective scenarios for biodiesel in Rio Grande do Sul - RS state, based on the Systems Thinking and Scenario Planning (STSP). It takes in account events, patterns of behaviour, systemic structures and mental models. A group for panellists evaluate the variables identified to choose the driving forces and uncertainties. The scenarios are then built based on two axes of the uncertainties: Effectiveness of public policies for the biodiesel chain in RS and Price of raw materials for production of biodiesel. As a combination of these uncertainties, four scenarios were built for the biodiesel industry in the state: competitive challenge, danger, better days will come, and grow and development (Vaccaro et al., 2010). In their set of scenarios, the biodiesel industry in the state depends strongly on public policies in order to be viable and sustainable (Vaccaro et al., 2010). This method has an advantage of combining qualitative and quantitative approach, but take a lot of time in meetings with the specialists, which may be impracticable to do in national scale where the experts are spread all over the country.

The choice for this work

Analysing the three basic assumptions for the future, the choice for this work is that the future can be built. The reasons are very simple. The first type of future, the pre-determined, assumes that the past will lead to the future. However, this approach is not enough to forecast the future, because the methods are not flexible to deal with the uncertainties, nor to highlight qualitative changes in the future (Porto, Nascimento, \& Buarque, 2001). The second assumption of future, that it is completely undetermined, makes any attempt to forecast useless. Consequently, the type of future that is according to the approach of the sustainable world must be the future that can be built. This assumption allows sustainability dimensions to be introduced in the methods of scenario design. The next step is to analyse how the images for the future area created or developed.

\footnotetext{
${ }^{8}$ Global Business Network, a consulting group sited in Berkeley, California, today part of Monitor, Deloitte, co-founded by Peter Schwartz
} 


\subsubsection{Process of future image development}

Bishop et al. (2007) provides a useful classification of the techniques of developed the images for the future, in 8 types (Bishop et al., 2007). They are shown and linked to the methods of scenario design for constructing the future. The Figure 12 resumes the rationale adopted.

The process for future image development are resumed as follows (Bishop et al., 2007):

a. Judgment: the techniques use judgment of the individual or group describing the future. Eventually, they may use information, analogy and reasoning but pure judgmental techniques have none of the methodological scaffolding that appears in the other categories;

b. Baseline: The main technique is to measure existing trends and extrapolate their effects into the future. One can do this by judgment or by mathematical techniques, if there is empirical data available. Next to pure judgment, trend extrapolation is the most common scenario technique: more people, more cars, more computers, more wealth, more liberties, etc.;

c. Elaboration of fixed scenarios (in-casting, SRI): these begin with scenarios that are decided ahead of time. The intention then is to elaborate the scenario logic or kernel, the simplest statement of what the scenario is about. The participants do not have to struggle with the uncertainties of the future. All they have to do is articulate the implications of given alternative futures;

d. Event sequences (probability trees, socio-vision, divergence mapping): the future is a series of events, even though we do not know which events will occur and which ones will not. Each event then has a probability of occurrence. If a potential event happens, the future goes one way; if not, then another. The future branches at each of those points depending on whether the event occurs or does not. In fact, more than one thing can happen in which case the future has three paths from that point. String a number of those branches together, and one has a probability tree:

e. Back-casting (horizon mission methodology, Impact of Future Technologies, future mapping): The first step is to envision a future state at the time horizon. It can be plausible or fantastical, preferred or catastrophic; but having established that state as a beachhead, it is easier to "connect the dots" from the present to the future (or back again) than it is to imagine the events leading to an unknown future. The technique is back-casting, as opposed to forecasting. 
f. Dimensions of uncertainty (morphological analysis, field anomaly relaxation, $\mathrm{GBN}^{9}$, MORPHOL, OS/SE): Scenarios in this section are constructed by first identifying specific sources of uncertainty and using those as the basis for alternative futures, depending on how the uncertainties play out.

g. Cross-impact analysis (SMIC PROF-EXPERT, IFS): These techniques identify various future conditions, events and even whole scenarios. Identify their characteristics and implications and also calculate their relative probabilities of occurrence. One can judge the single probability of a condition or an event using judgmental means. Nevertheless, those making the judgment have great expertise, their collective judgment presumably will be better.

h. Systems modelling (rend impact analysis, sensitivity analysis, and dynamic scenarios): Systems models are used primarily for baseline forecasting - i.e. predicting the expected future. Based on equations that relate the effects of some variables on others, the output is usually the expected value of target variables at the time horizon or graphs that show the change of those variables between the present and the time horizon. Any technique that can generate a single-valued prediction of the future can also produce scenarios by varying the inputs and/or the structure of the models that generate the prediction

For this work, the assumption is that the future can be built (Van Der Heijden, 2005), therefore, the interest lies in methods used to develop both normative and exploratory scenarios (Börjeson et al., 2006). From this specification, and according to Bishop et al. (2007), the group of methods that produce scenarios based on dimensions of uncertainty were chosen. This is compatible with the objective of this study, which is to discuss the dimensions that may produce scenarios that represent a sustainable image for the biodiesel industry.

\footnotetext{
${ }^{9}$ Global Business Network, a consulting group sited in Berkeley, California, today part of Monitor and Deloitte group, cofounded by Peter Schwartz
} 


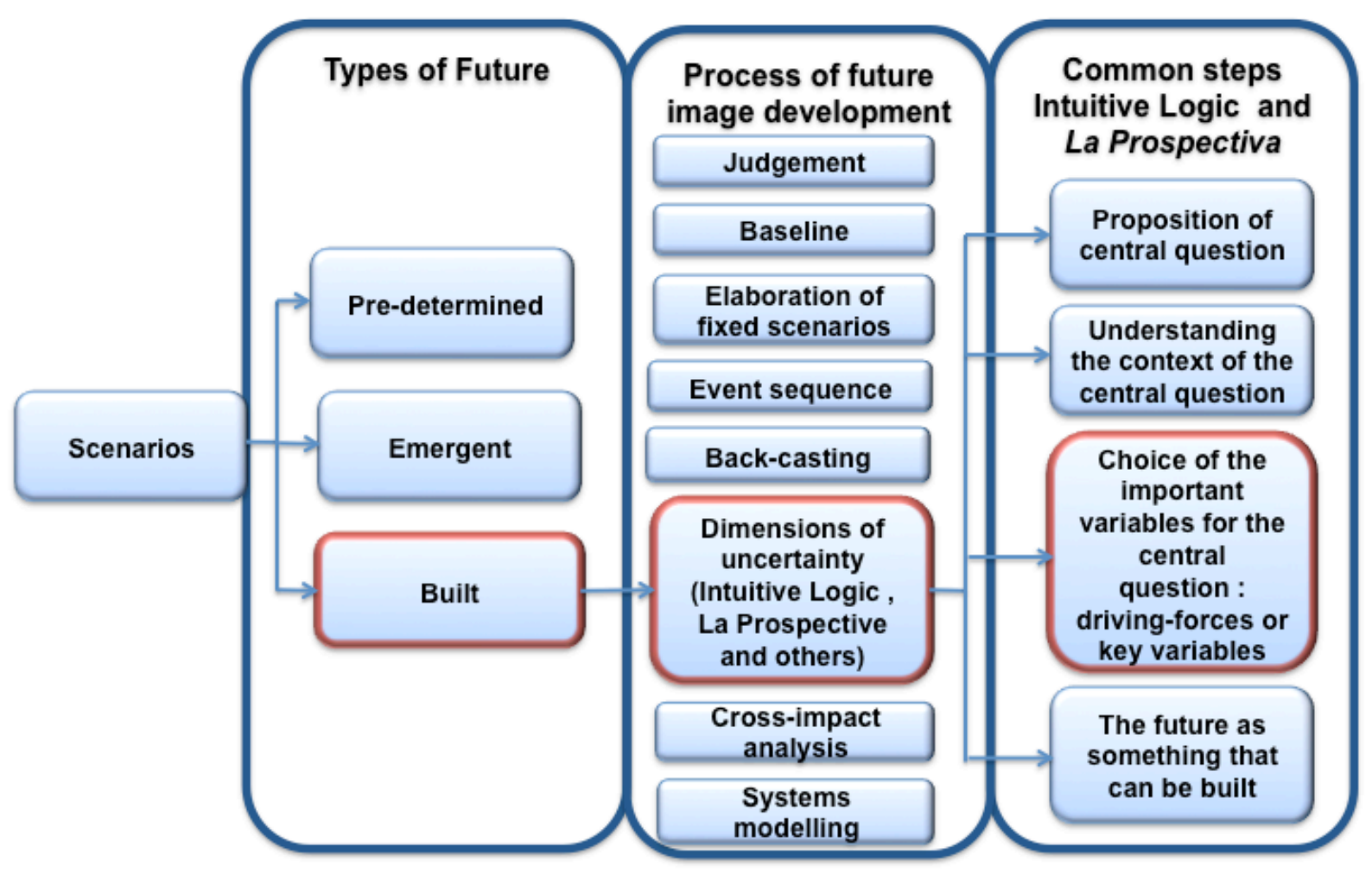

Source: Elaborated by the authors based on (Bishop et al., 2007; Börjeson et al., 2006; Bradfield, Wright, Burt, Cairns, \& Van Der Heijden, 2005; Durance \& Godet, 2010)

Figure 12 - Scheme of interest for this thesis

\subsubsection{Common steps to develop scenarios - the dimensions of uncertainty}

The interest in discussing the dimensions of uncertainty is their use as framework to construct images of the future. Included in this group, the GBN matrix, which is also called Intuitive Logic and La prospective, two of the most prominent schools for developing scenarios (Bradfield et al., 2005). Bishop sees similarities in techniques used by Intuitive Logic and a La prospective, in the scenarios development stage (Bishop et al., 2007). Indeed, the two schools have many common points (Bradfield et al., 2005), of which we highlight here:

- Proposition a central question around which will be constructed or designed scenarios;

- Understanding the context of the central question through historical data analysis (La prospective school) or through query (Intuitive Logic) specialists, or both ways;

- Choice of the important variables for the central question. They are called key variables or driving forces. The predetermined elements and critical uncertainties can derive from them (Durance \& Godet, 2010; Schwartz, 1996). These variables are combined in a frame in different ways according to the methodology chosen: GBN 
matrix structural analysis and morphological analysis. Then, the future images are created;

- Similar conceptions of the future as something that can be built, at least partially, so, not be fully anticipated. That puts them in the kind of humanist thought (Inayatulaah, 1993), and the procedural paradigm (Van Der Heijden, 2005). They produce normative or exploratory scenarios (Börjeson et al., 2006), which clearly differentiate these schools from others, which deal exclusively predictive scenarios (usually as a result of mathematical simulations and statistics).

Thus, from the methods that use the dimensions of uncertainty, the interest of this present work will be focused on the GBN matrix or Intuitive Logic methods (Bradfield et al., 2005) as outlined in Figure 12.

\subsubsection{Intuitive logic method}

After identifying the focal question for the scenarios, the identification of the key driving forces is through intuition, STEEP analysis, research, brainstorming, techniques, and expert opinions (Amer et al., 2013). Driving forces are what can modify the future of the focal question (Schwartz, 1996). The critical uncertainties are chosen amongst the driving forces (GBN, 2012)to make a GBN matrix, which is based on two dimensions of uncertainty or polarities (Bishop et al., 2007). There will be four combinations of the two uncertainties, each of which contains a logic of a plausible future (Bishop et al., 2007). Such scenarios usually have the a frame of 3-20 years; they are equally probable; and the output are a qualitative set of 2 to 4 scenarios, equally plausible, in narrative form (Amer et al., 2013; Bradfield et al., 2005). The identification of the driving forces and the critical uncertainties are done with the collaboration of experts in work teams.

\subsubsection{Images of the future}

According to Dator's observation (Dator, 1979), the images created by scenarios follow approximately four archetypes, irrespective of the method employed:

- Continued growth: in this future, it is assumed that the current conditions and trends are continued; it is often called "business - as-usual ";

- Steady state: in this future growth halts and a balance between economy and nature is sought. It highlights a balanced, softer and fairer society;

- Transformation: this future tries to change the basic assumptions of the other three. It emerges either through dramatic technological change or spiritual change;

- Collapse: continued growth fails and there are great contradictions in the future. 
The development of the future images has received several contributions towards increasing the detail or scope of the analysis. Dator (Dator, 1979) and Inayatullah (Inayatulaah, 2002) suggest that small insignificant issues, even if they are derived from quantitative variables, may have significant implications and suggest using Emerging Issue Analysis in the scenario work. Similarly, Van Der Heijden (Van Der Heijden, 2005) points out the facts of slow progression, which may cause great disasters or great opportunities. La prospective uses an analogous concept called facts that bring the future (Godet \& Durance, 2011)]. Wilkinson et al. (2013) suggest a reinterpretation of the Scenario Intuitive School with the help of the Complexity Theory (Wilkinson, Kupers, \& Mangalagiu, 2013). They also argue that beyond the drivers, it is necessary to look critically at the micro-causes which may have a decisive influence on the future through an emergent effect (Wilkinson et al., 2013). Structuring of future images remains under discussion, as do other elements that are necessary to provide a consistent theoretical framework for the existing practices. Pillkahn suggests that it is better to combine multiple methods and basic principles to ensure more robust scenarios (Pillkahn, 2008b).

Thus, considering the need to have any scenario that is sustainable, it was decided to discuss the dimensions of uncertainties before applying the chosen method (Intuitive logic or GBN matrix). The discussion can be found in the chapter 3, section 3.2.

\section{DeVeloping Scenarios: curRent possibilities and fUtURe Perspectives for BIODIESEL PRODUCTION IN BRAZIL}

\section{FOREWORD}

Various analyses have been made since Brazilian National Biodiesel Production and Use Program, PNPB, commenced. They have been concerned with assessing several aspects of the policy, such as environmental benefits/impacts, costs, competitiveness, energy efficiency, social inclusion, income generation, and so on. The general consensus is that in order to be sustainable fuel, Brazilian biodiesel production need to evolve, and all of the previous works bring valuable suggestions to the policy makers, specially concerning feedstocks. Nevertheless, a gap in the present research was identified regarding the various current possibilities. Some of the questions that arose are: to which degree could the suggestions presented in previous works be applied without changing the current land use? Would it currently be possible to produce more biodiesel from palm oil, nowadays? Would it be possible to increase the use of animal fat as feedstock? Are these feedstocks available?

Therefore, in order to conclude whether or not there are more sustainable possibilities for biodiesel, it was necessary to simulate all the possibilities of use of oils and fat that are 
produced and available in the country, to search for alternatives oilseeds, to look for regional possibilities, to know the amount of degraded land and more details. The first research article manuscript in this chapter addresses these questions.

The second manuscript deals with the scenario method. This gap was identified at the very beginning of the research since the scenario methods currently available do not include sustainable approach and have not been resulted in a sustainable alternative for the world. Quite to the contrary, they have just perpetuating the current situation. Consequently, it was necessary to work on a theoretical approach to solve this problem. It was also necessary to prove that the new method could produce different images for the future. Insight from first manuscript was submitted to the biodiesel market players, making an experiment that the theoretical approach indicates as necessary. In sum, the second manuscript addresses this methodological addresses and its practical application. The result is the critical uncertainties ready to be the framework for the storylines.

Finally, the third manuscript, starting with the critical uncertainties, goes to the scenarios storylines. Another practical concern became evident within the methodology of how to support the storylines with academic work. Once again, there were not many scientific papers located that speak to this point within the scenarios methods. Moreover, the Brazilian biodiesel market has special features such as formal regulation, geographic spreading, national production scale, and others that make it difficult to follow the techniques suggested by literature dealing with the procedures for workshops to create the storylines. As a result, this third manuscript addresses the technique to develop the storylines and their validation with an online Delphi survey.

In conclusion, each step of the work had different challenges that required tailored solutions. For this reason three manuscripts were prepared, each of them quite distinct, but all linked to the main objective of developing sustainable perspectives for the future of the biodiesel industry in Brazil. 


\title{
3.1 THE CHOICE OF FEEDSTOCKS FOR PRODUCING BIODIESEL: A CASE OF BRAZIL
}

\begin{abstract}
Brazilian biodiesel production relies mostly on soybean oil and beef tallow, even though it is possible to produce different oilseeds in the country. Several authors recommend the use of other feedstock based on different objectives or motives. This work analyses the current biodiesel production and simulates the possibilities of producing biodiesel from other feedstocks available in the country. It was based on three linear programming models: to minimize costs, to minimize land use, and to maximize the production. The concentration of the market in terms of feedstock mix was also evaluated. The results showed that it is possible to save land, diversify the feedstock, decrease the marketing concentration and regionalize the production. In addition, the results show that the percentage of oil used for biodiesel is about $14 \%$ of the total potential vegetal oil and animal fat produced in the country, suggesting there is no competition for land. However, soybean oil is the only feedstock produced in quantities large enough to meet the biodiesel national demand. In order to increase the production, and simultaneously, to diversify the feedstock used without causing deforestation nor impact other oilseeds market, it is necessary to restore degraded land, change pastureland to arable land, and grow oilseeds adapted to those lands. There is an additional potential production using residues, such as chicken and pork fat, and waste cooked oil. All of those options considered together can lead to huge increase of the biodiesel production helping to improve the regional development with a very positive impact on environment and land use, while recovering land.
\end{abstract}

Key words: biodiesel, biodiesel feedstock, diversification, production simulation 


\subsubsection{Introduction}

Brazil, with a successful experience producing ethanol since 1974, has increased biodiesel production steadily over the last 9 years (Figure 13). As soybean oil and beef tallow are the main primary sources (Figure 14), the use of these feedstock has provoked analysis from different points of view.

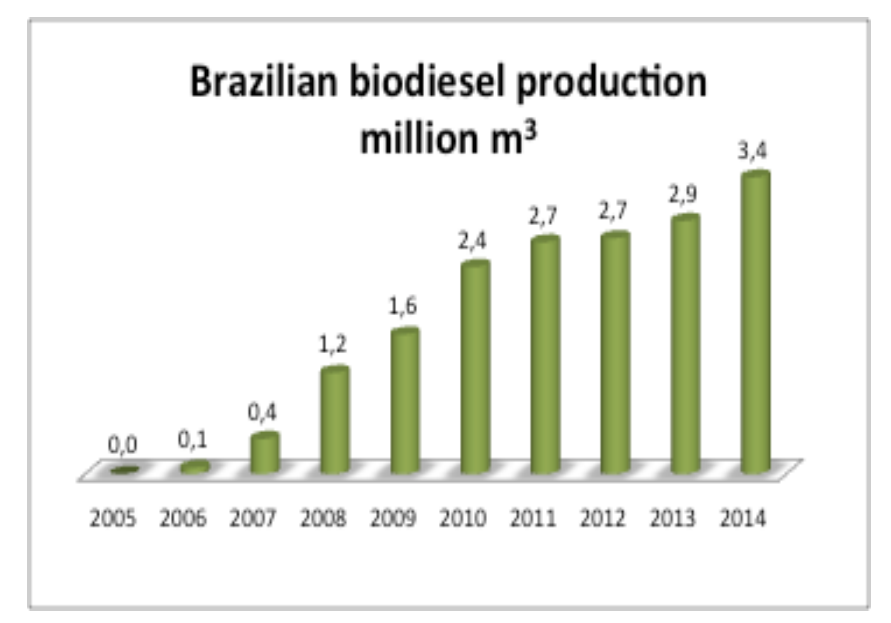

Source ANP, Oil, natural gas and biofuel statistical yearbook 2014

Figure 13 - Brazilian biodiesel production

Nogueira (Nogueira, 2011) suggests that besides beef tallow, palm oil should be used, not soybean, when concerned with the efficiency in solar energy conversion of the crops. Costa et al. (Costa et al., 2013) show that soybean oil is not the most economical, does not generate sufficient jobs, and offers less environmental benefits when compared to the use of residues (lard and chicken fat, cooked oil, scum, tallow and greases) for biodiesel feedstock. Sallet and Alvim (Sallet \& Alvim, 2011), highlight that soybean has a low yield, high costs; which influences food prices, and is failing to accomplish the social objectives of the National Biodiesel Program. Therefore, the regulatory framework of the Program should incorporate rules to avoid this. Padula et al. (Padula, Santos, Ferreira, \& Borenstein, 2012) analysis is related to the current aspects and future prospects, highlighting the diversification of feedstock, which has not yet occurred. They also recommended producing biodiesel from palm oil. Barros, Silva, Ponchi et al. (2006) (G.S.C Barros et al., 2006) evaluated the operational costs of producing biodiesel, and conclude that cotton from the state of Bahia is the least costly option to produce biodiesel in Brazil. However, analysing the investment need to meet the goals of the increasing of the blend until 2017, Barros et al. (2009) forecast that soybean will likely be the most used feedstock (G S C Barros, Alves, \& Osaki, 2009) $(70 \%)$, mainly because its production is already well established. They estimated that sunflower and cotton might also have smaller participations (6-30\%) in the future biodiesel 
production. Cremonez et al. (Cremonez et al., 2015) recalls that in Brazil there is a large range of oilseed crops that can be used as raw material, other than soybean. In addition, the authors state that the biodiesel production requires regionalization to create more jobs and improve the income of the small farmers. Bergman et al. (Bergmann et al., 2013)'s work demonstrates that other vegetal oil crops are able to be used as feedstocks for the biodiesel industry and call for a diversification of the feedstock used in Brazil. They also comment that each region of the country should produce biodiesel from its local plants. Indeed, relying mainly on two feedstocks can also present a risk of excessive vulnerability to market supply and prices, thereby affecting biodiesel production.

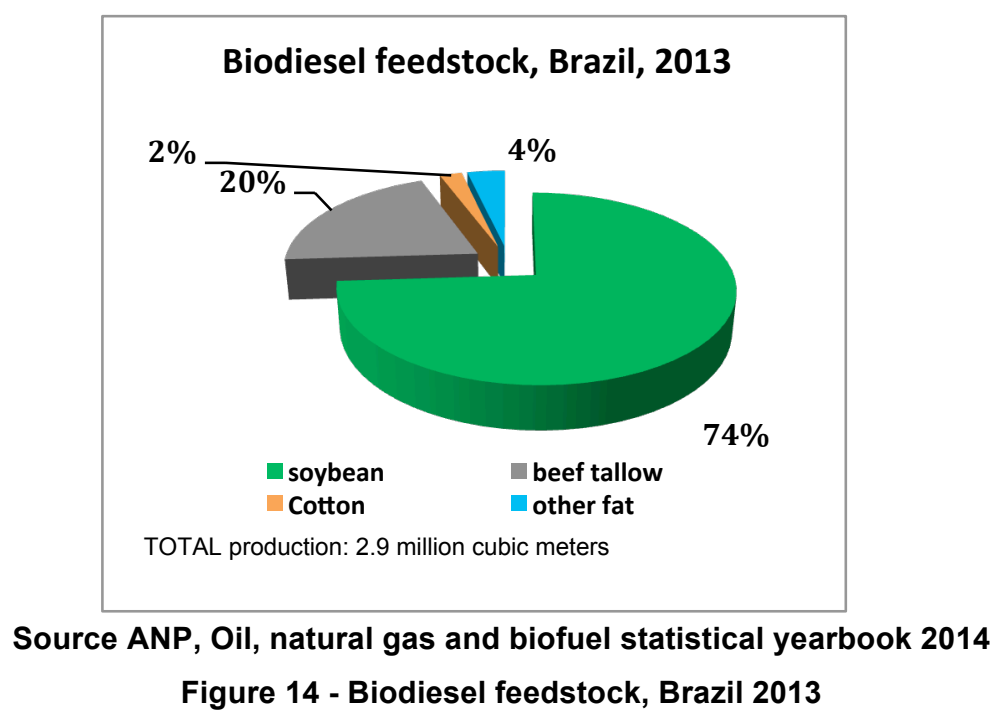

Whilst the above mentioned studies were based on valid criteria, none of them employed an analytical and quantitative approach to show what might be possible to change. In practical terms, would it be possible to change the feedstock mix, reducing costs and the land used? The objective of this work is to verify the extent to which it would be possible to produce biodiesel from other feedstock available in the country. The contributions of this work are to show that is possible to:

a) diversify the feedstock supply;

b) include other Brazilian regions in the production chain, making space for local development;

c) decrease the market concentration regarding feedstock supply;

d) have better use of land, using oilseeds that can grow in degraded or marginal land.

The paper takes two approaches: production on a regional and a national scale. Moreover, a concentration index was used to measure and compare the supply market concentration. 
The hypotheses for this approach were: there is enough feedstock in each region to meet the own biodiesel consumption; and the regional production can reverse the trend of market supply concentration.

\subsubsection{Materials and methods}

To allocate inputs from different sources to meet a demand, in an optimal way, it is quite usual to use Linear Programming Model (Hillier \& J., 2010). Therefore, three linear programming models were formulated to optimize the biodiesel production: to minimize costs and land use, and to maximize the production.

\subsubsection{First step: simulation with regional models}

Brazil's size is 851 Mha, which translates into a wide diversity of natural biomes, but also in terms of economic and social development. The 27 Brazilian states were grouped into six regions that are detailed in the section 3.1.2.4 Data. In order to have more accurate results, the national and regional models were used. Animal fat, cooked oil and fatty acid of soybean oil were considered residues. Therefore, there is no land dedicated for them.

\subsubsection{1.a Minimizing costs}

This simulation aimed to minimize the costs of producing biodiesel while meeting the real 2013 consumption. The yield of all possible oilseeds and the respective planted area was taken into account.

Minimizing costs required the object function:

$\min f(x)=\sum_{i=1}^{n} C i Y i, n=N$,

where

- $\quad C i$ is the cost for each $i$ oilseed (BR $\$$ /litres) for each region; (BR\$ denotes the currency Brazilian Reais)

- $\quad Y i$ is biodiesel produced from each $i$ oilseed, by region;

- $\quad N=$ number of oilseeds available for each region in the country.

Subject to the inequality constraints:

1) $\sum_{i=1}^{n} Y i \geq D, n=N$,

where

(2)

- $Y i=$ biodiesel produced from each oilseed $i$ in order to meet, at least, the $D$ consumption of Biodiesel in 2013;

- $\quad N=$ number of oilseed available for each region in the country, and 
2) $Y i \leq G i$, where

(3)

- $G$ is the current amount of biodiesel that can be produced from each oilseed $i$, per region. $G$ is obtained multiplying the oilseed yield (litres/ha) by the amount of land dedicated to each oilseed, per region.

\subsubsection{1.b Minimizing arable land use}

This simulation aimed to minimize the total land use regarding biodiesel production while meeting the real 2013 consumption. The yield of the oilseeds that could be used as feedstock and the respective planted area was taken into account.

Minimizing land use required the object function:

$\min f(x)=\sum_{i=1}^{n} X i, n=N$,

where

(4)

- $\quad X i$ is the land used (ha) to produce each $i$ feedstock, by region;

- $N=$ number of feedstock available for each region in the country.

Subject to the inequality constraints:

1) $\sum_{i=1}^{n} A X i \geq D, n=N$ where

- $A i$ is the average yield of the feedstock $i$ (litres/ha) for the last 4 harvests (20102013), considering the planted area in each state of the region;

- $\quad X i=$ land used to produce each oilseed $i$ in order to meet, at least, the $D$ consumption of Biodiesel in 2013;

- $N=$ number of feedstock available for each region in the country, and

2) $X i \leq B i$, where

(6)

- $B$ is the amount of land use (ha) for each oilseed per region.

\subsubsection{1.c Maximizing the production}

The objective was to estimate the maximum potential of biodiesel that could have been produced, given the average production of oilseeds, and the respectively land use, in the last 4 years. These simulations do not allocate land. Instead, they take the land used to estimate the best combination of oilseeds to produce biodiesel.

To simulate the maximum production the object function is:

$$
\max f(x)=\sum_{i=1}^{n} A i X i, \mathrm{n}=N \text {, where }
$$


- $A i$ is the average yield of the feedstock $i$ (litres/ha) for the last 4 harvests (20102013), considering the planted area in each state of the region;

- $\quad X i$ is land for each feedstock $i$ (ha) produced in the region in the last four harvests (2010-2013).

- $\quad N=$ number of feedstock available in the whole country. The same oilseed that is produced in different regions was considered separately because they have different yields.

Subject to inequality constraints:

$X i \leq B i$, where

- $B i$ is the average amount of land used (in hectares, ha) for the feedstock $i$ in the last four years, to assure the current land use will be respected.

Therefore, the decisions variables are the amount of land for producing each oilseed (in each region) that can be feedstock for biodiesel. The value of the objective function will be the total amount of biodiesel that can be produced from these oilseeds. After obtaining the regional results, they were added in order to have national results.

\subsubsection{Second step: simulation with national models}

All the models describe in 3.1.2.1 were carried out for the country as a whole.

The optimization models were solved with the procedure OPTMODEL, from SAS 9.4. The data was organized with Excel and SPSS.

\subsubsection{Third step: concentration Index}

Last, the normalized Herfindahl-Hirschaman Index - HHI $\mathrm{NOR}_{\mathrm{N}}$ was computed for the simulated results and compared to the real situation. This index measures the level of market concentration, computing the sum square of the percentage of participation for each organization in the same market. Using the normalized formula:

$$
H H I_{N O R}=\left[\left(\sum_{i=1}^{n} S i^{2}\right)-1 / n\right] /(1-1 / n)
$$

Where:

- $i$ integer;

- $n=$ number of feedstock in the market;

- $S$ is the percentage of the participation of each feedstock $i$ in the market.

This index is used mainly in economic sectors to measure the market concentration. Here it is used to give this idea of concentration and level of dependency of the biodiesel industry on few feedstock. The range of $\mathrm{HHI}$ goes from 1 to 10.000 . The normalized $\mathrm{HHI}$ goes from zero to one. The analysis relies in the range of the index: below 0.15 , it indicates a 
competitive market; from 0.15 to 0.25 : moderate competition; above 0.25 : highly concentrated $^{10}$. Using this index to represent the feedstock concentration makes sense since in such a country like Brazil, with a wide variety of climate conditions and land available, there are several oilseeds crops that could be feedstock for biodiesel(Angarita et al., 2008). Comparing the index of the optimized solution with the real situation can help assess the possibility of diversifying the supply under the current condition, e.g. without changing the land use.

\subsubsection{Data}

\subsubsection{4.a Planted area}

The planted area for each oilseed, yield, quantity of slaughtered cattle, pork and chicken was based IBGE (Brazilian Institute of Geography and Statistics) database (SIDRA) and Monthly Agricultural Census - PMA (IBGE, 2015b); and CONAB (National Supply Company) data (CONAB, 2015a). In order to avoid any bias from seasonal results related to a particular year, the average from the last four years was taken. The biodiesel demand was chosen to be the consumption from 2013 (mandate of 6\%), which was greater than the previous years. Therefore, all the results can be considered conservative because the ability to meet the biodiesel demand can be greater if the yield and planted area is considered year by year. Having the average yield for each feedstock, the average percentage of oil was calculated, based on data from a Brazilian government report (Brazil, 2013).

\subsubsection{4.b Regions and oilseeds}

In order to have the most homogeneous and broad data regarding crop yield, the figures were grouped into the standard Brazilian political regions and then modified by the proposition of World Bank report (WORLDBANK, 2011). The regions are as follow: South region (states of Rio Grande do Sul, Paraná and Santa Catarina), Southeast region (states of Minas Gerais, São Paulo, Rio de Janeiro and Espírito Santo), Northeast coast (states of Sergipe, Alagoas, Pernambuco, Paraíba, Rio Grande do Norte and Ceará), MAPITOBA region (states of Maranhão, Piauí, Tocantins and Bahia), North Amazon (states of Acre, Amazonas, Rondônia, Roraima, Amapá, Pará and the municipalities of Mato Grosso that are in the Amazon biome), and finally Centre-West Cerrado that includes Mato Grosso do Sul, Goiás, Distrito Federal and the municipalities of Mato Grosso that are in Cerrado biome (Figure 15). This grouping was chosen in order to provide more consistent results since the states included in each grouping are quite homogenous in terms of productivity.

\footnotetext{
${ }^{10}$ Reference values for highly concentrated markets are above 0.25 . Based on guidelines http://www.justice.gov/atr/public/guidelines/hmg2010.html
} 


\subsubsection{4.c. Costs}

The feedstock represents around $80 \%$ of the cost of biodiesel production (G.S.C Barros et al., 2006; Duncan, 2003; Haas, McAloon, Yee, \& Foglia, 2006). Thus, only the feedstock that had previously calculated costs and had been planted in the last four years were considered, namely; sunflower, soybean, cotton, peanuts, castor beans and palm oil. Combining the regions and feedstock, there were 32 variables related to feedstock used in the model, because each region has distinct yield and costs for each feedstock (Table 7).

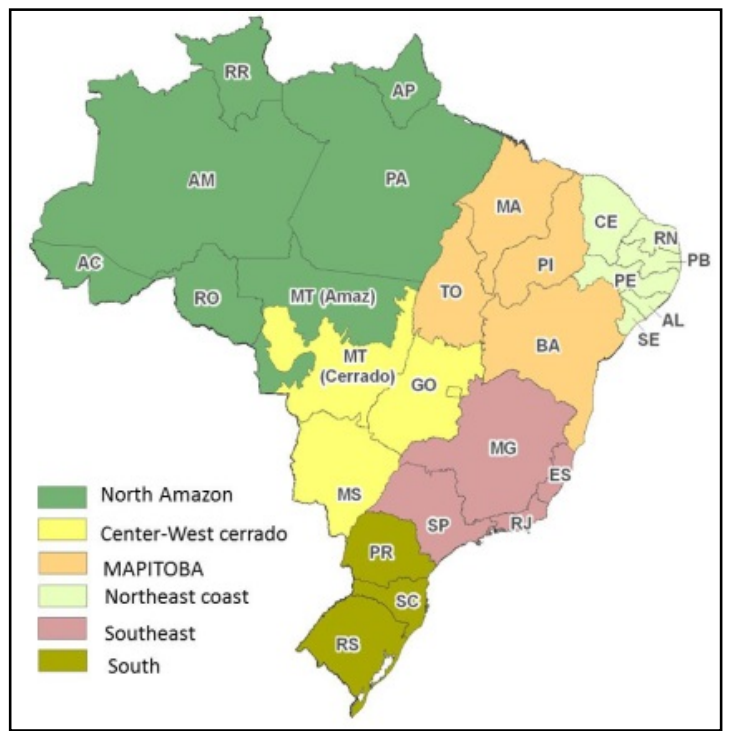

Source: ICONE, by personal communication (Harfuch, 2014).

Figure 15 - Regions considered in the analysis

Table 7 - Feedstock by region

\begin{tabular}{l|c|l}
\hline Region & $\begin{array}{c}\text { Number of } \\
\text { feedstock }\end{array}$ & Feedstock \\
\hline South & 5 & $\begin{array}{l}\text { Sunflower, Soybean, Peanuts, Cotton and Castor beans } \\
\text { Southeast }\end{array}$ \\
MAPITOBA & 6 & $\begin{array}{l}\text { Sunflower, Soybean, Peanuts, Cotton and Castor beans } \\
\text { Sunflower, Soybean, Peanuts, Cotton, Castor beans and Palm } \\
\text { oil } \\
\text { Sunflower, Soybean, Peanuts, Cotton, Castor beans } \\
\text { Sunflower, Soybean, Peanuts, Cotton, Castor beans and Palm } \\
\text { oil } \\
\text { Northeast coast }\end{array}$ \\
$\begin{array}{l}\text { North Amazon } \\
\text { Centre West, } \\
\text { Cerrados }\end{array}$ & 5 & 5 \\
\multicolumn{2}{l}{ Source: elaborated by the authors Soybean, Peanuts, Cotton, Castor beans } \\
\end{tabular}

The cost of producing biodiesel from oilseeds were taken from Barros et al. (2006), for a 40000 ton/year plant, taking the cost of the feedstock in $\mathrm{BR} \$ /$ litres. For larger plants, it is expected the costs will decrease, because of economies of scale. When there is no 
estimated cost, the cost for the same feedstock for the closest region was taken. This may interfere somewhat in the regional results.

Biodiesel production costs were taken based on the production costs of the feedstock, not in the feedstock market prices feedstock market prices. The simulations assume that all the oil produced would be available for biodiesel production, to explore the possibilities of using other feedstock. Therefore, this is not an economic simulation.

\subsubsection{4.d. Animal fat}

The rationale of the model did not fit well the dynamics of animal fat yield. Data from the 2006 agriculture census show there are 172 million hectares of pasture land (IBGE, 2015b). Updated estimates of pastureland in Brazil reach the number of 230 Mha (Soares-Filho, 2013). However, this number can include degraded pasture, extensive and intensive grazing. Therefore, the yield of 1,1 heads per hectare (ha) (IBGE, 2015b) or $23 \mathrm{~kg}$ of beef tallow (10\% of the weight of fat (Nelson \& Schrock, 2006)) are general figures. There is not accurate data about how much land is effectively occupied by cattle. Thus, the beef tallow yield is not comparable to oilseed yield by hectare. Under the point of view of land use, the biodiesel yield is very low: it is 32 litres/ha from cattle against the average of 600 litres/ha from soybean, 472 from castor beans, 978 from peanuts, 4000 from macaúba and cocconut, and 2800 from palm oil. There is a lack of assessments about the costs to produce biodiesel from beef tallow or other animal fat in Brazil.

Pork fat was estimated according to Dutra et al. (Dutra Jr et al., 2001) as an average of $10 \%$ of the total weight. A conservative percent of poultry fat was taking as $0.142 \%$ of the total weight according to EMBRAPA ${ }^{11}$, even though some authors estimated that there may be until $10 \%$ of the weight of the bird (BECKER, SPENCER, MIROSH, \& VERSTRATE, 1979; Shumaker, McKissick, Ferland, \& Doherty, 2003).

It was not possible to have a reliable potential for cooked oil, neither for fish fat. Therefore, these residues were not used as potential. All residues were added to the simulations as exogenous variable, due the assumption that there is no land destined to produce residues.

Beef tallow, pork fat and chicken fat have been used as feedstock for biodiesel. Also, have been cooked oil and fatty acid soybean oil (residue from the soybean processing). However, the animal fat available is much greater. Thus, animal fat and residues were considered in two different models: one count the whole potential given by the average amount of slaughtered animals in the last 4 years; and other count just the amount effectively

\footnotetext{
${ }^{11}$ Brazilian Agricultural Research Corporation https://www.embrapa.br/suinos-e-aves/
} 
used in 2013, including animal fat, cooked oil, and beef tallow fatty acid soybean oil (see details in Table 8 and in 3.1.2.5).

\subsubsection{Procedures}

The simulations were made at regional (called A models) and national (called B models) levels, to minimize costs, minimize land use and maximizing production, according to Table 8 .

3.1.2.5.a Regional models (A): minimizing costs, minimizing land use, and maximizing production

Simulation at the regional level occurred by taking into account the feedstock with 32 variables distributed into 6 regions according to the Table 7, and by following the procedure in Table 8.

For each region, besides the constraint of the land used for each feedstock, yield and costs; the constraint to meet the biodiesel consumption in 2013 in each region was considered. This means that each region would produce enough to meet its own regional demand (item 3.1.2.1).

For each model (A.1, A.2, A.3) three sets of feedstock were used: a) just oilseeds (average from the last 4 years), oilseeds (average from the last 4 years) plus the potential animal fats available (average of the 4 years), c) oilseeds and the real animal fats and other residues used in 2013.

The results were summed to provide a national perspective. They summed to 6 results from minimizing regional models, according to the right column at the Table 8 , and 1 result from maximizing model.

3.1.2.5.b National model (B): minimizing costs, minimizing land use, and maximizing production

The same simulations described in 3.2.5.1.a were performed at the national level according to the Table 7, with 32 variables, following the same procedures and combination of feedstocks, according to the Table 8. This national approach simulation ran in order to compare to the regional in terms of concentration of feedstocks, feedstock mix, and saving land. They also summed to 6 results and 1 result from maximizing model.

\subsubsection{Limitations of the research}

This work strongly depends on the data from the sources consulted, namely: the production, the productivity, costs, oil percentage in each feedstock and so on. Part of the models depends on the costs computed by Barros et al. (2006). Therefore, significant 
changes in the proportionality of the production costs between the feedstock can change the results of minimizing costs models. Changes in yield may also change the results. Some crops were not considered in this analysis, even though they have expressive amount of land dedicated to it in Brazil, because the data available is not at the same level of accuracy and periodicity of the others. This is the case of coconut.

Table 8 - Simulation models

\begin{tabular}{|c|c|c|c|c|c|}
\hline Scale & $\begin{array}{l}\text { Objective } \\
\text { function }\end{array}$ & Feedstock & \multicolumn{2}{|l|}{ Constraints } & Analysis \\
\hline \multirow{3}{*}{ A. Regional } & $\begin{array}{l}\text { A.1.Minimize costs } \\
\text { (18 models: } 6 \\
\text { regions } 63 \text { models })\end{array}$ & $\begin{array}{l}\text { All oilseeds produced } \\
\text { All oilseeds produced } \\
\text { and potential animal } \\
\text { fat } \\
\text { All oilseeds produced } \\
\text { and animal fat and } \\
\text { residues used in } \\
2013\end{array}$ & $\begin{array}{l}\text { Meet the } \\
\text { regional demand }\end{array}$ & $\begin{array}{l}\text { Total biodiesel } \\
\text { that can be } \\
\text { produced from } \\
\text { each oilseed, per } \\
\text { region }\end{array}$ & $\begin{array}{l}\text { - Each region } \\
\text { - Each set of } \\
\text { feedstock } \\
\text { summed in the } \\
\text { national level (3 } \\
\text { results) }\end{array}$ \\
\hline & $\begin{array}{l}\text { A.2.Minimize land } \\
\text { use } \\
\text { (18 models: } 6 \\
\text { regions } \times 3 \text { models) }\end{array}$ & $\begin{array}{l}\text { All oilseeds produced } \\
\text { All oilseeds produced } \\
\text { and potential animal } \\
\text { fat } \\
\text { All oilseeds produced } \\
\text { and animal fat and } \\
\text { residues used in } \\
2013\end{array}$ & $\begin{array}{l}\text { Meet the } \\
\text { regional demand }\end{array}$ & $\begin{array}{l}\text { Total land use to } \\
\text { crop r each } \\
\text { oilseed, } \\
\text { region }\end{array}$ & $\begin{array}{l}\text { - Each region } \\
\text { - Each set of } \\
\text { feedstock } \\
\text { summed in the } \\
\text { national level ( } 3 \\
\text { results) }\end{array}$ \\
\hline & $\begin{array}{l}\text { A.3.Maximize } \\
\text { production } \\
\text { models) }\end{array}$ & All oilseeds produced & $\begin{array}{l}\text { Total land use to } \\
\text { per region }\end{array}$ & op each oilseed, & $\begin{array}{l}\text { Summed in national } \\
\text { level ( } 1 \text { result) }\end{array}$ \\
\hline \multirow{3}{*}{ B. National } & $\begin{array}{l}\text { B.1. Minimize costs } \\
\text { ( } 3 \text { models })\end{array}$ & $\begin{array}{l}\text { All oilseeds produced } \\
\text { All oilseeds produced } \\
\text { and potential animal } \\
\text { fat } \\
\text { All oilseeds produced } \\
\text { and animal fat and } \\
\text { residues used in } \\
2013\end{array}$ & $\begin{array}{l}\text { Meet the national } \\
\text { demand }\end{array}$ & $\begin{array}{l}\text { Total biodiesel } \\
\text { that can be } \\
\text { produced from } \\
\text { each oilseed, per } \\
\text { region }\end{array}$ & $\begin{array}{l}3 \text { results at National } \\
\text { level }\end{array}$ \\
\hline & $\begin{array}{l}\text { B.2 Minimize land } \\
\text { use } \\
\text { ( } 3 \text { models })\end{array}$ & $\begin{array}{l}\text { All oilseeds produced } \\
\text { All oilseeds produced } \\
\text { and potential animal } \\
\text { fat } \\
\text { All oilseeds produced } \\
\text { and animal fat and } \\
\text { residues used in } \\
2013\end{array}$ & $\begin{array}{l}\text { Meet the national } \\
\text { demand }\end{array}$ & $\begin{array}{l}\text { Total land use to } \\
\text { crop reach } \\
\text { oilseed, per } \\
\text { region }\end{array}$ & $\begin{array}{l}3 \text { results at National } \\
\text { level }\end{array}$ \\
\hline & $\begin{array}{l}\text { B.3 Maximize } \\
\text { production (1 model) }\end{array}$ & All oilseeds produced & \multicolumn{2}{|c|}{$\begin{array}{l}\text { Total land use to crop each oilseed, } \\
\text { per region }\end{array}$} & $\begin{array}{l}\text { National level } \quad(1 \\
\text { result) }\end{array}$ \\
\hline
\end{tabular}

Source: Elaborated by the authors

\subsubsection{Results}

In order to provide a reference, the Table 9 shows the data for 2013 biodiesel production, by feedstock, land used (estimated) and computed $\mathrm{HHI}$. Notice that the land used was calculated based on the average yield of the crop considering the region the biodiesel was produced. There is no information about where the oil comes from. So, the assumption was 
that the oil was produced in the same region the biodiesel was produced. These estimates agreed with Nogueira (2011).

Regional results are useful to analyse if each region can meet its own demand, and how it can be done. The regional results were summed to compare to the national approach, and find out which would be the best production structure regarding land use and concentration market. Minimizing models count 12 results (Table 10). Maximizing model counts 2 results one from regional approach, other from national approach (A.3 and B.3 on the Table 8). They as listed on 3.1.3.2.

Table 9 - Brazilian biodiesel production, 2013

\begin{tabular}{ccc}
\hline Feedstock & $\begin{array}{c}\text { Biodiesel production } \\
\text { (thousand } \mathbf{~ m}^{\text {) }}\end{array}$ & $\begin{array}{c}\text { Land for crops } \\
\text { (thousand ha) }\end{array}$ \\
\hline $\begin{array}{c}\text { Soybean } \\
\text { beef tallow }\end{array}$ & 2,159 & 3,230 \\
Cotton & 590 & 405 \\
other fatty material & 63 & - \\
cooked oil & 67 & - \\
palm oil & 29 & 0.006 \\
macauba oil & 9 & $\mathbf{3 , 6 4 3}$ \\
oil turnip-feed & 0.03 & \\
\hline TOTALS & 1 & $\mathbf{0 . 5 3}$ \\
\hline HHI & $\mathbf{2 , 9 1 7}$ & \\
\hline
\end{tabular}

Source: Elaborated by the authors, based on National Petroleum agency (ANP). www.anp.gov.br (P. N. A. ANP, 2014) and Conab database (CONAB, 2015b).

\subsubsection{Minimize models - costs and land use}

The results of each simulation were assessed taking account the total land use and the feedstock concentration. Even though the costs were used to simulate, it was decided to not consider them to assess the solutions, because they cannot remain stable over the years.

The summary of the simulation results are in Table 10. The two right columns represent the assessment regarding concentration index (column A) and land use (column B). The smaller the number, the smaller the land use and HHI. It is also possible to see the level of diversification in the columns "\% soybean" and "other oilseeds".

The 2013 production was assessed according to the same criteria and received the number correspondent to the order. It is $11^{\text {th }}$ related to $\mathrm{HHI}$ and $7^{\text {th }}$ regarding land use. It is showed in the first row. Every model that has smaller numbers than 11 at the column (A), is less concentrated than the real production. It counts 10 results. Taking the results of the 
models for minimizing land use, it is possible to see at the column (B), that 6 results have less land dedicated to the oilseeds than the real production.

\subsubsection{1.a Regional approach - results 1 to 6}

At regional level, all regions could meet their own demand, but the northeast. This region can produced the maximum 12.9 thousand $\mathrm{m}^{3}$, not enough to meet its demand of 223.9 thousand $\mathrm{m}^{3}$ of biodiesel (in 2013). The remained demand was transferred to MAPITO region, the closest one.

From all of the feedstocks available (Table 7), palm oil and peanuts were the ones prioritized by the optimization model when the objective function was to minimize land use. Nevertheless, cotton was the first feedstock chosen, when the objective function was to minimize costs. These could be observed in the log function of the software used (SAS). Taking advantage of peanuts, sunflower, cotton, castor beans, palm oil, and animal fat, the biodiesel production would have a diversified supply of feedstocks and still save land. This can be seen in Table 10, the results of the models 3,5 and 6 . The models 2 to 6 showed better concentration index $(\mathrm{HHI})$. All regional models used 4 to 5 different feedstocks besides soybeans.

\subsubsection{1.b National approach - results 7 to 12}

This set of results have 3 options of saving land compared to 2013 production and 5 results with $\mathrm{HHI}$ less than the 2013 production (Table 10). The simulations that use the greatest number of oilseeds and the greatest share are models 7, 9 and 11. All of them are minimizing land use models. They use 5 oilseeds (other than soybean) counting $21 \%$ of the total share of feedstocks. The feedstock with the greatest participation after soybean is cotton, with $34 \%$, in the models 8 and 12 . These models aimed to minimize costs. Indeed, it has the cheapest production cost all over Brazil (G.S.C Barros et al., 2006) and its oil yield in Centre-west region is comparable to the soybean (CONAB, 2015b). Even though the cotton planted area was the second greatest in 2013 (2.8 Mha), it is far from soybean area (27.1 Mha) (CONAB, 2015b). Regarding beef tallow and residues, models 11 and 12 show the greatest participation $30 \%$ and $23 \%$.

\subsubsection{1.c Overall analysis}

Considering only the models which results are better than the 2013 production, in both criteria - land use and $\mathrm{HHI}$, namely models 3, 5, 6, 9, 11 and 12, the ones with the greatest share of other oilseeds besides soybean were the models 10 and 12 . However, they count only 1 or 2 different oilseeds: cotton in model 12, and cotton and palm oil in model 10. 
The four best results regarding number of oilseeds, oilseed (non-soybean) share, minimum of land used and $\mathrm{HHI}$, are the models numbers 5 and 6 , regional approach, and the numbers 11 and 12, national approach. The details of the four best results can be seen at Table 11.

Table 10 - Summarized results

\begin{tabular}{|c|c|c|c|c|c|c|c|c|c|c|c|c|}
\hline & & & & \multirow{2}{*}{$\%$ soybean } & \multicolumn{2}{|c|}{ other oilseeds } & \multirow{2}{*}{$\begin{array}{l}\text { \% beef } \\
\text { tallow }\end{array}$} & \multirow{2}{*}{$\begin{array}{l}\% \text { other } \\
\text { residues }\end{array}$} & \multirow{2}{*}{$\begin{array}{l}\text { Land use } \\
\text { estimated } \\
\text { (Thousand } \\
\text { HA) }\end{array}$} & \multirow{2}{*}{ HHI } & \multirow{2}{*}{$\begin{array}{l}\text { Order in } \\
\text { terms of } \\
\text { HHI (A) }\end{array}$} & \multirow{2}{*}{$\begin{array}{c}\text { Order } \\
\text { regarding } \\
\text { land use } \\
\text { (B) }\end{array}$} \\
\hline & & & & & How many & Total share & & & & & & \\
\hline & \multicolumn{3}{|c|}{ Real production for comparison } & $74 \%$ & 4 & $3 \%$ & $20 \%$ & $3 \%$ & 3.6 & 0.53 & 11 & 7 \\
\hline \multirow{6}{*}{$\mathrm{M}$} & \multirow{6}{*}{$\begin{array}{l}\text { Regional } \\
\text { approach }\end{array}$} & 1. Minimize land use & oilseeds & $81 \%$ & 5 & $19 \%$ & $0 \%$ & $0 \%$ & 4.2 & 0.59 & 13 & 11 \\
\hline & & 2. Minimize costs & oilseeds & $69 \%$ & 4 & $31 \%$ & $0 \%$ & $0 \%$ & 4.7 & 0.43 & 10 & 12 \\
\hline & & 3. Minimize land use & $\begin{array}{l}\text { oilseeds, but using } 2013 \text { quantities of } \\
\text { animal fat and residues }\end{array}$ & $60 \%$ & 5 & $17 \%$ & $20 \%$ & $3 \%$ & 3.1 & 0.36 & 9 & 6 \\
\hline & & 4.Minimize costs & $\begin{array}{l}\text { oilseeds, but using } 2013 \text { quantities of } \\
\text { animal fat and residues }\end{array}$ & $52 \%$ & 4 & $24 \%$ & $20 \%$ & $3 \%$ & 3.8 & 0.31 & 7 & 8 \\
\hline & & 5. Minimize costs & $\begin{array}{c}\text { oilseeds, but using } 2013 \text { potential } \\
\text { quantities of animal fat }\end{array}$ & $36 \%$ & 5 & $13 \%$ & $29 \%$ & $22 \%$ & 2.6 & 0.08 & 3 & 4 \\
\hline & & 6. Minimize land use & $\begin{array}{c}\text { oilseeds, but using } 2013 \text { potential } \\
\text { quantities of animal fat }\end{array}$ & $36 \%$ & 4 & $13 \%$ & $29 \%$ & $22 \%$ & 2.2 & 0.12 & 5 & 2 \\
\hline \multirow{3}{*}{ e } & \multirow{6}{*}{$\begin{array}{l}\text { National } \\
\text { approach }\end{array}$} & 7. Minimize land use & oilseeds & $79 \%$ & 5 & $21 \%$ & $0 \%$ & $0 \%$ & 3.9 & 0.56 & 12 & 9 \\
\hline & & 8. Minimize costs & oilseeds & $66 \%$ & 1 & $34 \%$ & $0 \%$ & $0 \%$ & 4.8 & 0.11 & 4 & 13 \\
\hline & & 9. Minimize land use & $\begin{array}{l}\text { oilseeds, but using } 2013 \text { quantities of } \\
\text { animal fat and residues }\end{array}$ & $56 \%$ & 5 & $21 \%$ & $20 \%$ & $3 \%$ & 2.9 & 0.31 & 8 & 5 \\
\hline \multirow[t]{3}{*}{$\mathrm{S}$} & & 10. Minimize costs & $\begin{array}{l}\text { oilseeds, but using } 2013 \text { quantities of } \\
\text { animal fat and residues }\end{array}$ & $44 \%$ & 2 & $33 \%$ & $20 \%$ & $3 \%$ & 3.9 & 0.26 & 6 & 10 \\
\hline & & 11. Minimize land use & $\begin{array}{c}\text { oilseeds, but using } 2013 \text { potential } \\
\text { quantities of animal fat }\end{array}$ & $25 \%$ & 5 & $21 \%$ & $30 \%$ & $23 \%$ & 1.6 & 0.06 & 2 & 1 \\
\hline & & 12. Minimize costs & $\begin{array}{l}\text { oilseeds, but using } 2013 \text { potential } \\
\text { quantities of animal fat }\end{array}$ & $13 \%$ & 1 & $34 \%$ & $30 \%$ & $23 \%$ & 2.5 & 0.03 & 1 & 3 \\
\hline
\end{tabular}

Source: computing and organized by the authors.

\subsubsection{Results of maximization of the production}

AS it was already mentioned in 3.1.2.4.d, it was not possible to estimate the amount of cooked oil, because there is no data available. However, all the potential of animal fat was added to final results of the maximize models of the biodiesel production. Using all the vegetal oil and animal fat produced in the country, it is possible to produce 7 times the amount of biodiesel (21.4 million $\mathrm{m}^{3}$ ) than was consumed in 2013 (Table 12). Both approach (national and regional) had the same results. This result is important because it indicates that biodiesel consumes $14 \%$ of the theoretical potential vegetal oil and fat produced in Brazil. However, without any particular plan to diversify the feedstock, any increasing of the mandate may result in greater concentration of the feedstock market. The maximization model of production shows that concentration index $-\mathrm{HHI}$ can reach 0.66 , leading soybean to have a greater share in the feedstock mix. 
Table 11 - Four best solutions for Land use and HHI

\begin{tabular}{|c|c|c|c|c|c|c|c|}
\hline \multicolumn{4}{|c|}{ 5. REGIONAL Minimize costs } & \multicolumn{4}{|c|}{ 6. REGIONAL Minimize land use } \\
\hline Feedstock & $\begin{array}{c}\text { Production } \\
\text { (Thousand } \\
\mathrm{m}^{3} \text { ) }\end{array}$ & $\begin{array}{c}\% \\
\text { production }\end{array}$ & $\begin{array}{l}\text { Land use } \\
\text { (MHA) }\end{array}$ & Feedstock & $\begin{array}{c}\text { Production } \\
\text { (Thousand } \\
\mathrm{m}^{3} \text { ) }\end{array}$ & $\begin{array}{c}\% \\
\text { production }\end{array}$ & $\begin{array}{c}\text { Land use } \\
\text { (MHA) }\end{array}$ \\
\hline Soybean & 842 & $28 \%$ & 1.3 & Soybean & 1109 & $36 \%$ & 1.8 \\
\hline Beef tallow & 886 & $29 \%$ & & Beef tallow & 886 & $29 \%$ & \\
\hline Cotton & 595 & $20 \%$ & 1.2 & Cotton & 146 & $5 \%$ & 0.2 \\
\hline Palm oil & & $0 \%$ & & Palm oil & 53 & $2 \%$ & 0.1 \\
\hline Castor Beans & 9 & $0 \%$ & 0.04 & Castor Beans & 12 & $0 \%$ & 0.0 \\
\hline Peanuts & 9 & $0 \%$ & 0.01 & Peanuts & 172 & $6 \%$ & 0.1 \\
\hline Sunflower & 3 & $0 \%$ & 0.01 & Sunflower & 5 & $0 \%$ & 0.0 \\
\hline Chicken fat & 201 & $7 \%$ & & Chicken fat & 201 & $7 \%$ & \\
\hline Pork fat & 477 & $16 \%$ & & Pork fat & 477 & $16 \%$ & \\
\hline TOTALS & 3022 & $100 \%$ & 2.6 & TOTALS & 3062 & $100 \%$ & 2.2 \\
\hline $\mathrm{HHI}$ & & 0.08 & & $\mathrm{HHI}$ & & 0.11 & \\
\hline \multicolumn{2}{|c|}{ Land use 2013 production } & & 3.6 & \multicolumn{2}{|c|}{ Land use 2013 production } & & 3.6 \\
\hline \multicolumn{2}{|c|}{ HHI 2013 production } & 0.53 & & \multicolumn{2}{|c|}{ HHI 2013 production } & 0.53 & \\
\hline \multicolumn{4}{|c|}{ 11. NATIONAL Minimize land use } & \multicolumn{4}{|c|}{ 12. NATIONAL Miminize costs } \\
\hline Feedstock & $\begin{array}{c}\text { Production } \\
\text { (Thousand } \\
\mathrm{m}^{3} \text { ) }\end{array}$ & $\begin{array}{c}\% \\
\text { production }\end{array}$ & $\begin{array}{l}\text { Land use } \\
\text { (MHA) }\end{array}$ & Feedstock & $\begin{array}{c}\text { Production } \\
\text { (Thousand } \\
\mathrm{m}^{3} \text { ) }\end{array}$ & $\begin{array}{c}\% \\
\text { production }\end{array}$ & $\begin{array}{c}\text { Land use } \\
\text { (MHA) }\end{array}$ \\
\hline Soybean & 738 & $25 \%$ & 1.1 & Soybean & 369 & $13 \%$ & 0.54 \\
\hline Beef tallow & 886 & $30 \%$ & & Beef tallow & 886 & $30 \%$ & \\
\hline Cotton & 170 & $6 \%$ & 0.2 & Cotton & 992 & $34 \%$ & 1.97 \\
\hline Palm oil & 232 & $8 \%$ & 0.1 & Palm oil & & $0 \%$ & \\
\hline Castor Beans & 5 & $0 \%$ & 0.0 & Castor Beans & & $0 \%$ & \\
\hline Peanuts & 176 & $6 \%$ & 0.1 & Peanuts & & $0 \%$ & \\
\hline Sunflower & 41 & $1 \%$ & 0.1 & Sunflower & & $0 \%$ & \\
\hline Chicken fat & 201 & $7 \%$ & & Chicken fat & 201 & $7 \%$ & \\
\hline Pork fat & 477 & $16 \%$ & & Pork fat & 477 & $16 \%$ & \\
\hline TOTALS & 2925 & $100 \%$ & 1.6 & TOTALS & 2925 & $100 \%$ & 2.5 \\
\hline $\mathrm{HHI}$ & & 0.06 & & $\mathrm{HHI}$ & & 0.03 & \\
\hline \multicolumn{2}{|c|}{ Land use 2013 production } & & 3.6 & \multicolumn{2}{|c|}{ Land use 2013 production } & & 3.6 \\
\hline \multicolumn{2}{|c|}{ HHI 2013 production } & 0.53 & & \multicolumn{2}{|c|}{$\mathrm{HHI} 2013$ production } & 0.53 & \\
\hline
\end{tabular}

Source: computing and organized by the authors.

\subsubsection{Discussion}

The results brought about four points to discuss:

a) Diversification of the feedstock supply;

b) Regional approach for the biodiesel production;

c) Market concentration regarding feedstock supply;

d) Better use of land, using oilseeds that can grow in degraded or marginal land. 
Table 12 - Results of maximize model to produce biodiesel in Brazil, in 2013

\begin{tabular}{|c|c|c|c|c|}
\hline \multicolumn{5}{|c|}{ Maximize production models, 2013} \\
\hline Feedstock & $\begin{array}{c}\text { Biodiesel } \\
\text { (Thousand } \mathrm{m}^{3} \text { ) }\end{array}$ & Percentage & $\begin{array}{c}\text { Land } \\
\text { (Million ha) }\end{array}$ & HHI \\
\hline Sunflower & 50 & $0.2 \%$ & 0.1 & \multirow{10}{*}{0.66} \\
\hline Soybean & 17,878 & $83 \%$ & 27 & \\
\hline Peanuts & 177 & $1 \%$ & 0.1 & \\
\hline Cotton & 1,528 & $7 \%$ & 3 & \\
\hline Castor beans & 30 & $0.1 \%$ & 0.1 & \\
\hline Palm oil & 232 & $1 \%$ & 0.1 & \\
\hline Beef talow & 886 & $4 \%$ & & \\
\hline Chicken fat & 201 & $1 \%$ & & \\
\hline Pork fat & 477 & $2 \%$ & & \\
\hline TOTALS & 21,459 & $100 \%$ & 30.4 & \\
\hline
\end{tabular}

Source: computing and organized by the authors

\subsubsection{Diversification of the feedstock supply}

The concentration of the biodiesel feedstock market on soybean oil means that the biodiesel is subject to the risks of the soybean market such as crop shortfall and volatility of the international prices. They mean agriculture risks in the National energy market, because the biodiesel feedstock price is linked to the fluctuation of the international commodity market (Pedroti, 2013). This is a vulnerability that is far beyond the Brazilian Government control. The feedstock diversification is one alternative to reduce those risks. Also, it can bring regional development (Pedroti, 2013).

\subsubsection{1.a Oilseeds}

The simulation results showed that there are other oilseeds that would be used to produce biodiesel namely peanuts, cotton, sunflower, palm oil and castor beans, meeting the requirement of Padula et al. (Padula et al., 2012). Currently, most of this vegetal oil is destined to food industry. Therefore, to take advantage of this variety, it is necessary to increase their production expanding the planted area, e.g. changing the land use.

Palm oil and peanuts have the best yield. Peanuts grow in all regions (Table 7). In order to optimize the land use, peanuts and palm oil are better choices. However, both are destined for the food-processing industry, making them more valuable in the market. Indeed, the market value of the peanut oil is much greater than its production cost (G.S.C Barros et al., 2006). Cotton has the lowest cost (G.S.C Barros et al., 2006) and its oil yield is compared to soybean and sunflower (CONAB, 2015b), what explains why cotton remains as a good 
option under the current conditions in all models. Indeed, cotton had the greatest share after soybean in all models. It has the second greatest planted area after soybean (CONAB, $2015 b$ ); the oil is a by-product, and it is not a demanding crop regarding water and soil type.

In order to produce biodiesel from the perspective of a more efficient energy solar conversion, Palm oil and beef tallow would be the best choices (Nogueira, 2011). Regarding palm oil, it would be necessary to utilize 730 to 2,345 thousand ha, representing 7 to 21 times the area currently used for biodiesel in Brazil. This could be done either through deforestation or through the restoration of degraded land. However, according to Englund at al. (Englund, Berndes, Martin Persson, \& Sparovek, 2015) there are 26 Million ha of deforested land available in Amazon Biome that could be used to produce palm oil. The Brazilian Sustainable Program of Palm oil estimates 31 Mha are suitable for Palm oil (Brazil, 2010b), in Amazon biome (mostly in Centre-West and North amazon regions), by an Agroecological zoning of palm oil. Most of them are degraded land, since the Program prohibits converting native forest into palm oil plantation.

If all of this area is converted to palm oil plantations over a timeframe of 7-14 years, 104 million cubic meters of biodiesel - enough to meet $10 \%$ of the world demand of mineral diesel (Englund et al., 2015) could be produced. On other words, planting 30 million ha palm oil, with a yield of 3000 litres of biodiesel/ha will result in roughly 90 million $\mathrm{m}^{3}$ oil/year. The current national demand for palm oil is about 1 million ton/year in Brazil (Levermann \& Souza, 2014), while the current internal demand for biodiesel is 3.4 million $\mathrm{m}^{3} /$ year. In addition to being more productive, palm oil can also contribute to jobs creation more significantly than other biodiesel feedstocks (Costa et al., 2013). Indeed, although palm oil plantations can take up to 7 year to start producing, both establishing and managing the plantation are relatively labour intensive compared other rural activities (Englund et al., 2015).

Other oilseeds have been researched as possible feedstocks like babassú, macaúba, pequi, oil-turned feed and coconut. Some of them were already used to produce biodiesel like macaúba and oil-turned feed in Brazil and coconut in German. However, they still need to improve the scale production.

\subsubsection{1.b Animal fats and residues}

Brazil is one the largest meat production in the world (FAO, 2015). Animal fat is used mostly by soap industry, and by animal feed industry. But not all of the available fat goes to these industries. Part of them has to be disposed - that costs money and, sometimes, cause environmental problems. Considering conservative percentages of fat for poultry, pork and 
cattle (Table 13), there is a potential of 1.5 million cubic meters ${ }^{12}$ of biodiesel that would be produced in 2013 exclusively from animal fat. However, the biodiesel produced from animal fat, in 2013 was $609 \mathrm{~m}^{3}$, mostly from beef tallow (Table 8). Therefore, the animal fat, especially from beef tallow, is a significant potential as a feedstock, what agreed to Costa et al. (Costa et al., 2013).

Table 13 - Biodiesel and Animal Fats

\begin{tabular}{lcccccc}
\hline & $\begin{array}{c}\text { Weight of } \\
\text { carcasses } \\
\text { (tons) }\end{array}$ & fat & fat (tons) & $\begin{array}{c}\text { Potential } \\
\text { biodiesel } \\
\text { production } \\
\mathbf{m}^{\mathbf{3}}\end{array}$ & $\begin{array}{c}\text { used in } \\
\mathbf{2 0 1 3}, \mathbf{~ m}^{\mathbf{3}}\end{array}$ & $\begin{array}{c}\text { \% of the } \\
\text { potential is } \\
\text { used }\end{array}$ \\
\hline Cattle & $7,108,889$ & $10 \%$ & 710,888 & 885,613 & 590,156 & $58 \%$ \\
Poultry & $11,503,979$ & $1,4 \%$ & 163,356 & 201,106 & 885 & $0.6 \%$ \\
Pork & 796,394 & $12 \%$ & 95,567 & 476,875 & 17,520 & $9 \%$ \\
\hline TOTAL & \multicolumn{7}{c}{$\mathbf{9 6 9 , 8 1 1}$} & $\mathbf{1 , 5 6 3 , 5 9 4}$ & $\mathbf{6 0 8 , 5 6 1}$ & $\mathbf{4 4 \%}$ \\
\hline \multicolumn{7}{c}{ Source: elaborated by the author based on IBGE (IBGE, 2015b) and ANP (P. N. A. ANP, 2014) }
\end{tabular}

In Brazil, approximately 6 billion litres of oil per year is used for cooking (ABIOVE, 2015). There is no accurate data about how much waste oil can be reused to produce biodiesel. Some works have demonstrated that it is less costly to produce biodiesel form waste cooked oil than from edible oil (Costa Neto \& Rossi, 2000; Gui, Lee, \& Bhatia, 2008; Oliveira, 2004; Zhang, Dubé, McLean, \& Kates, 2003). In addition, using cooked oil as feedstock helps to solve the disposal problems. Nowadays, cooked oil has been used in small proportions to produce biodiesel (28,647 thousand litres in 2013 - Table 9) in Brazil. But, more production from cooked oil is being planned (PETROBRAS, 2014).

The results of minimize models show that animal fat and other residues would contribute to de-concentrate the feedstock supply, under the current conditions of land use. Moreover, the comparison between real production (Table 9) and the solutions for land use (Table 11) shows that it is possible to save more than $50 \%$ of the total land used, if the shares of animal fat and other residues in the biodiesel production increase.

\subsubsection{Regional approach for the biodiesel production}

Currently, Brazilian biodiesel production is concentrated in South and Centre-West regions

Figure 16). The simulations with regional approach (A models - Table 8) showed that it would be possible to regionalize the production. Only the northeast region could not produce biodiesel to meet its own demand, under the current conditions. However, by respecting the

\footnotetext{
${ }^{12}$ Considering $1 \mathrm{l}$ of biodiesel $=0,8 \mathrm{~kg}$ of fat
} 
necessary soil and weather conditions (Palacio et al., 2010), macaúba ${ }^{13}$, babassú, coconut and cotton would help to diversify the supply and develop those poorest regions in the country, with the lowest socioeconomic indicators, such as the Human Development Index, HDIs (Table 14), which is the case for the Northeast coast, MAPITOBA and North regions. Those oilseeds can meet their proper soil and weather conditions to grow in those states (Angarita et al., 2008).

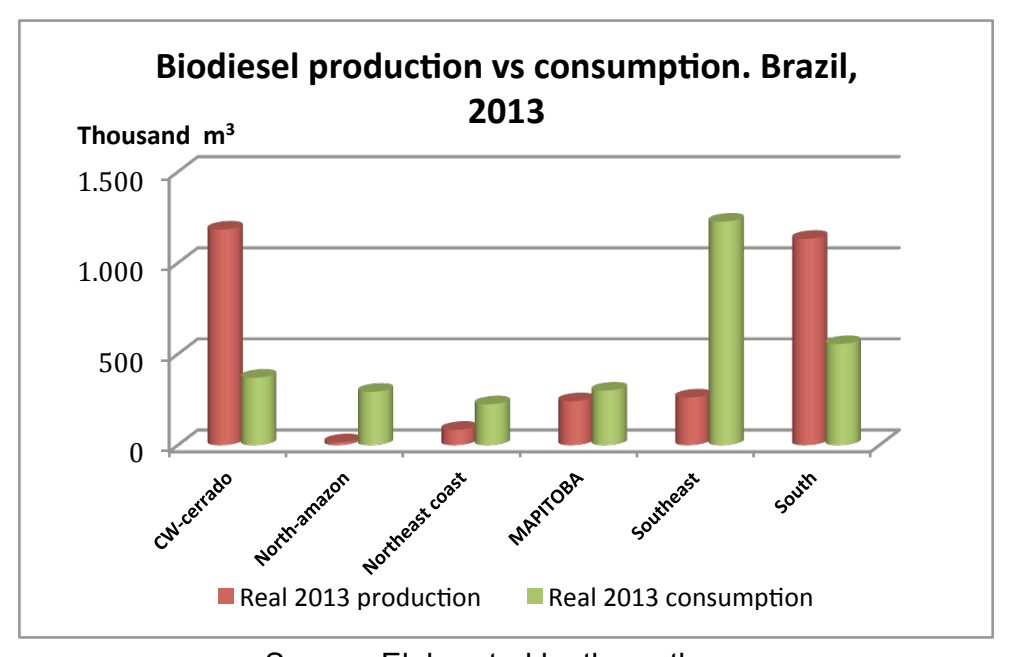

Source: Elaborated by the author

Figure 16. Brazilian biodiesel production vs Consumption (2013)

Moreover, the regional production of biodiesel, especially in remote communities in North amazon and Northeast, would also help them generating electricity as well as being used as a transportation fuel.

\subsubsection{Market concentration regarding feedstock supply}

The Brazilian biodiesel production is strongly dependent on the soy and meat markets. Looking at all results in Table 10, the choices to decrease $\mathrm{HHI}$ are easily found, once only 2 out 12 results has $\mathrm{HHI}$ greater than the real production. It means that, even though soybean has the greatest arable area (27.9 Mha in 2013)(CONAB, 2015b), far from the second oilseed consider (cotton with 1 Mha in 2013) (CONAB, 2015b), other feedstock could be used. Therefore, to de-concentrate the biodiesel market, without changing the land use, the choice would be using other feedstock, as commented in 3.1.4.1 or taking a regional approach (3.1.4.2).

\footnotetext{
${ }^{13}$ In 2013, it was used to produce a small quantity of biodiesel, but it can produce 4000 litres of oil per ha in arid and degraded land.
} 
Table 14 - Regional Human Development Index 2010

\begin{tabular}{ll}
\hline REGION & HDI \\
\hline South & 0.75 \\
Southeast & 0.75 \\
Center-West & 0.75 \\
North Amazon & 0.68 \\
North East Coast & 0.66 \\
MAPITOBA & 0.66 \\
Source: elaborated by authors from IBGE data(IBGE, 2015a)
\end{tabular}

However, for mandates greater than the current 7\% (B7), biodiesel production must be supplied by soybean mostly, what will continue the trend of concentration of the market. This can be assumed looking at the results of the maximized model (Table 12).

\subsubsection{Better use of land, using oilseeds that can grow in degraded or marginal land}

According to the Table 10, there are 6 results that save land, namely models 3,5 and 6 (regional approach) and 9, 11 and 12 (national approach). However, using other oilseeds requires medium and long term planning in order to not impact other markets and prices. Better alternatives would be achieved converting pastureland to crop or restore degraded land. The pasture land nowadays count 176 Mha (IBGE, 2015b) using extensive pasture. Changing half of this land would more than double the arable land in Brazil, which is currently around 57 Mha (IBGE, 2015b). Part of this land would be restored by using oilseeds adapted to degraded land namely macaúba, pequi (Antunes, Zuppa, Antoniosi Filho, \& Castro, 2006; Bergmann et al., 2013), or even castor beans and cotton that have lower demand for water and nutrients.

Even palm oil is being used to restore degraded land in North region (BRAZIL, 2010a). This suggests that, choosing a feedstock that can grow in degraded or marginal land would result in better land use and would add more environment gains to the biodiesel production. The production from those feedstocks can also help to regionalize the biodiesel production, which impacts have already been discussed in section 3.1.4.2.

\subsubsection{Conclusion}

Currently, it is difficult to make major changes in the biodiesel production in Brazil due to current land use. However, even with the available feedstock, the present market 
concentration could be reduced improving the competitiveness and the stability of the supply, by increasing the share of peanuts, palm oil, cotton, sunflower, and animal fat.

The hypothesis that there is enough feedstock in each region to meet the own biodiesel consumption was confirmed for 5 out of 6 regions. The second hypothesis that the regional production can reverse the trend of market supply concentration also was confirmed. Public policies that prioritize regional approach to biodiesel production could take advantage of local crops, which are abundant in Brazil. Such crops are adapted to the local soil and weather conditions, and can help to restore degraded land. Moreover, the regional approach would decentralize the production, decreasing the transportation costs, and would help to develop poorer regions in the country.

However, the best solutions for de-concentrated the supply market were adding animal fat to optimize land use. It means that using residues and the most productivity crops will deconcentrated market and save land.

The production of biodiesel in Brazil uses mostly by-products and consumes only $14 \%$ of the total oil produced in the country. The total biodiesel production can grow to meet an increase in the mandate without causing deforestation, nor displace crops, by using plants that can grow on marginal and degraded land, as well as using animal residues and cooked oil. If Brazil explores all these possibilities, it could also be a major exporter of biodiesel through social, environmental and economically sustainable production.

\section{Contributions}

Dias did the model and wrote most of the manuscript. Bentsen supervised and discussed the model and the results; reviewed the manuscript. Felby discussed the results and made a critical review fo the manuscript.

\section{Financial support}

There is no specific financial support for this research, but a comprehensive PhD scholarship funded by CAPES-BRAZIL.

\section{Conflict of interest}

The authors declare that is no conflict of interest in this research.

\section{Acknowledges}

The authors thank to Professor Gerd Sparovek and Professor Ole John Nielsen for helpful discussions. 


\subsubsection{References}

ABIOVE. (2015). Balanco de Oferta/Demanda (1000t). Retrieved from http://www.abiove.org.br/site/_FILES/Portugues/03112015-120354-2015-11-03__quadro_de_oferta_e_demanda.pdf

André Cremonez, P., Feroldi, M., Cézar Nadaleti, W., de Rossi, E., Feiden, A., de Camargo, M. P., . . . Klajn, F. F. (2015). Biodiesel production in Brazil: Current scenario and perspectives. Renewable and Sustainable Energy Reviews, 42(0), 415-428. doi:http://dx.doi.org/10.1016/j.rser.2014.10.004

Angarita, E. E. Y., Lora, E. E. S., Costa, R. E., Lamônica, H. m., Finguerut, J., Ramirez, G. A. S., \& Nascimento, M. A. R. (2008). Production of vegetable oils and biodiesel: technology and life-cycle assessment (in Portuguese). In L. A. B. Cortez, E. E. S. Lora, \& E. Gómez (Eds.), Biomass for energy (in Portugues) (pp. 734). Campinas: Editora Unicamp.

ANP, P. N. A. (2014). Brazilian statistical yearbook of oil, gas and biofuel 2014.

Antunes, E. C., Zuppa, T. O., Antoniosi Filho, N. R., \& Castro, S. S. (2006). Utilização do pequi (Caryocar brasiliense camb) como espécie recuperadora de ambientes degradados no cerrado e fornecedora de materia prima para a producao de biodiesel. Paper presented at the I congresso da rede brasileira de tecnologia do biodiesel, Brasília. http://www.agencia.cnptia.embrapa.br/Repositorio/pequi1_000g6vgwdq802wx5ok0wt edt3zzxcrff.pdf

Barros, G. S. A. d. C., Alves, L. R. A., \& Osaki, M. (2009). Necessidades de investimentos e otimizacao da producao agropecuaria com o programa de biodiesel no Brasil. Paper presented at the SOBER 470. congresso da sociedade brasileira de economia, administracao e sociologia rural., Porto Alegre, RS.

Barros, G. S. A. d. C., Silva, A. P., Ponchi, L. A., Alves, L. R. A., Osaki, M., \& Cenamo, M. (2006). Custos de produção de biodiesel no Brasil. Revista da Política Agrícola, 3, 36-50.

BECKER, W. A., SPENCER, J. V., MIROSH, L. W., \& VERSTRATE, J. A. (1979). Prediction of Fat and Fat Free Live Weight in Broiler Chickens Using Backskin Fat, Abdominal Fat, and Live Body Weight. Poultry Science, 58(4), 835-842. doi:10.3382/ps.0580835

Bergmann, J. C., Tupinambá, D. D., Costa, O. Y. A., Almeida, J. R. M., Barreto, C. C., \& Quirino, B. F. (2013). Biodiesel production in Brazil and alternative biomass feedstocks. Renewable and Sustainable Energy Reviews, 21(0), 411-420. doi:http://dx.doi.org/10.1016/j.rser.2012.12.058

BRAZIL. (2010). Programa Federal de Produção Sustentável de Óleo de Palma (PSOP). Retrieved

from http://www.agricultura.gov.br/arq_editor/file/camaras_setoriais/Palma_de_oleo/1_reu niao/Programa.pdf

Brazil/MAPA. Programa Federal de Produção Sustentável de Óleo de Palma (PSOP). Retrieved 
http://www.agricultura.gov.br/arq_editor/file/camaras_setoriais/Palma_de_oleo/1_reu niao/Programa.pdf

Brazil/MAPA. (2013). Brazilian Statistical Yearbook of Agrienergy 2012.pdf. Retrieved from Brasilia:

CONAB. (2015a). Companhia nacional de abastecimento. Retrieved from www.conab.gov.br

CONAB. (2015b). Levantamento de Safra. Retrieved from http://www.conab.gov.br/conteudos.php?a=1253\&

Costa, A. O., Oliveira, L. B., Lins, M. P. E., Silva, A. C. M., Araujo, M. S. M., Pereira Jr, A. O., \& Rosa, L. P. (2013). Sustainability analysis of biodiesel production: A review on different resources in Brazil. Renewable and Sustainable Energy Reviews, 27, 407412. doi:10.1016/j.rser.2013.06.005

Costa Neto, P. R., \& Rossi, L. F. S. (2000). Produção de biocombustivel alternativo ao oleo diesel atraves da transesterificacao de oleo de soja usado em frituras. Quimica nova, 23(4).

Duncan, J. (2003). Energy Efficieny and Conservation Authority. Retrieved from New Zeland:

Dutra Jr, W., Ferreira, A. S., Tarouco, J. U., Euclydes, R. F., Donzele, J. L., Lopes, P. S., \& Cardoso, L. L. (2001). Estimativas de Rendimentos de Cortes Comerciais e de Tecidos de Suínos em Diferentes Pesos de Abate pela Técnica de Ultra-sonografia em Tempo Real. Revista Brasileira de Zootecnia, 30(4). doi:http://dx.doi.org/10.1590/S1516-35982001000500017

Englund, O., Berndes, G., Martin Persson, U., \& Sparovek, G. (2015). Oil palm for biodiesel in Brazil-risks and opportunities. Environmental Research Letters, 10(4), 044002. doi:10.1088/1748-9326/10/4/044002

FAO, F. a. A. O. o. t. U. N. (2015). FAOSTAT. Retrieved from http://faostat3.fao.org/home/E

Gui, M. M., Lee, K. T., \& Bhatia, S. (2008). Feasibility of edible oil vs. non-edible oil vs. waste edible oil as biodiesel feedstock. Energy, 33(11), 1646-1653. doi:http://dx.doi.org/10.1016/j.energy.2008.06.002

Harfuch, L. (2014). [Brazil map with 6 regions].

Hillier, F. S., \& J., L. G. (2010). Introduction to operations research (9a. ed.). Singapore: McGrawHill.

Haas, M. J., McAloon, A. J., Yee, W. C., \& Foglia, T. A. (2006). A process model to estimate biodiesel production costs. Bioresource Technology, 97(4), 671-678. doi:http://dx.doi.org/10.1016/j.biortech.2005.03.039

IBGE. (2015a). Instituto Brasileiro de Geografia e Estatística. Retrieved from www.ibge.gov.br

IBGE. (2015b). Instituto Brasileiro de Geografia e Estatística - PAM - Pesquisa Agropecuária Municipal. Retrieved from www.ibge.gov.br 
Levermann, R. A., \& Souza, J. P. M. d. (2014, February, 2014). Oleo de palma - O crescimento da indústria global. AGROANALYSIS - a revista de agronegócio da FGV.

Nelson, R. G., \& Schrock, M. D. (2006). Energetic and economic feasibility associated with the production, processing, and conversion of beef tallow to a substitute diesel fuel. Biomass and Bioenergy, 30(6), 584-591. doi:http://dx.doi.org/10.1016/j.biombioe.2005.09.005

Nogueira, L. A. H. (2011). Does biodiesel make sense? Energy, 36(6), 3659-3666. doi:http://dx.doi.org/10.1016/j.energy.2010.08.035

Oliveira, L. B. (2004). Potencial de aproveitamente energético de lixo e de biodiesel de insumos residuais no Brasil. (PhD report), Universidade Federal do Rio de Janeiro, Rio de Janeiro.

Padula, A. D., Santos, M. S., Ferreira, L., \& Borenstein, D. (2012). The emergence of the biodiesel industry in Brazil: Current figures and future prospects. Energy Policy, 44, 395-405. doi:10.1016/j.enpol.2012.02.003

Palacio, J. C. E., Lora, E. E. S., Venturini, O. J., \& Olmo, O. A. d. (2010). Biocombustíveis, meio ambiente, tecnologia e seguranca alimentar. In E. E. S. V. Lora, Osvaldo José (Ed.), Biocombustíveis (1a. Ed. ed., Vol. 1, pp. 1158). Rio de Janeiro, Brasil: Editora Interciencia.

Pedroti, P. M. (2013). The challenges of development and social inclusion: the case of the political-institutional arrangement of the Nacional Program of Productiona and Use of Biodiesel in Brazil (in portuguese). Retrieved from Rio de Janeiro: www.ipea.gov.br

PETROBRAS. (2014, February, 7th, 2014). Petrobras Biocombustível produzirá mais biodiesel a partir de óleo de cozinha usado. Retrieved from http://www.petrobras.com.br/fatos-e-dados/petrobras-biocombustivel-produzira-maisbiodiesel-a-partir-de-oleo-de-cozinha-usado.htm

Sallet, C. L., \& Alvim, A. M. (2011). Biocombustíveis: uma análise da evolução do biodiesel no Brasil. Economia \& Tecnologia, 25(April/June 2011).

Shumaker, G., McKissick, J., Ferland, C., \& Doherty, B. (2003). A study of the feasibility of biodiesel production in Georgia. Retrieved from Georgia, USA:

Soares-Filho, B. S. (2013). The impact of the forest law revision: how to turn the big challenge ahead, viable? (in portuguese). Retrieved from Brasilia: http://www.socioambiental.org/sites/blog.socioambiental.org/files/nsa/arquivos/artigocodigo-florestal_britaldo_soares_sae_2013pdf.pdf

WORLDBANK. (2011). Brazil low carbon case study - technical Synthesis report: land use, land-use change, and forestry. Retrieved from

Zhang, Y., Dubé, M. A., McLean, D. D., \& Kates, M. (2003). Biodiesel production from waste cooking oil: 2. Economic assessment and sensitivity analysis. Bioresource Technology, 90(3), 229-240. doi:10.1016/s0960-8524(03)00150-0 
3.2 SUSTAINABILITY IN THE PROSPECTIVE SCENARIOS METHODS: A PRACTICAL APPLICATION OF SCENARIOS FOR BIODIESEL INDUSTRY IN BRAZIL, FOR 2030

\begin{abstract}
This section was included to fill the methodological gap of having a method of built scenarios that is able to show sustainable images of the future. It was necessary to develop a cross-disciplinary work to include Sachs' dimensions of sustainability into the scenarios method. This meant linking concepts from different disciplines, without transforming it in a new discipline. In order to support the proposition for the new method, a practical application is presented: the framework for the biodiesel scenarios in Brazil, by 2030. An in-depth interview was used to test the proposition of having the sustainability dimensions as driving forces. The result was the identification of a critical uncertainty composed of various aspects related the response to climate change and environmental conservation. The scenario storylines that were developed based on the critical uncertainties showed that sustainable options for the future are possible if the mental maps are enlarged to see beyond the business as usual.

The results show that the scenarios storylines go through social, environmental and economic aspects, supported by other aspects like the territorial and political. Also it showed that sustainable options are possible if the mental maps are enlarged to see beyond the business as usual.
\end{abstract}

Keywords: biodiesel; critical uncertainties; sustainability; methodology; mental maps 


\subsubsection{Introduction}

The methods and techniques to plan for the future are called Scenario Planning, Development Scenario, Forecasting, and Foresight or more generally, Future Studies. Scenarios are the products of Future Studies whilst they are the stories that represent the future. So far, planning for future or not, as human beings, the world today is not sustainable: natural resources have been depleted over the past two centuries. Moreover, about 795 million people are undernourished (FAO, IFAD, \& WFP, 2015), 780 million people do not have access to clean water and almost 2.5 billion do not have access to adequate sanitation (UNWATER, 2013). Therefore, it is apparent that the plans for the future needs to be modified to reinforce the commitment with the future generations, and to show more balance between economic, social and environmental perspectives. However, Futures Studies is a body of knowledge that does not have an established theoretical and scientific structure (Bishop et al. (2007); (Bradfield et al., 2005; Wilkinson, 2009). There have been some valuable reviews organizing and structuring the techniques and the methods ${ }^{14}$ (Amer et al., 2013; Bishop et al., 2007; Börjeson et al., 2006; Bradfield et al., 2005; Chermack, 2005; Varum \& Melo, 2010), which have made good progress, but there are aspects that remain to addressed, some of which will be elaborated upon in the upcoming paragraphs.

One important aspect of the Future Studies is the development of the images that represent the future. It would be necessary to discuss how the future images are structured, how paths to social change are proposed in these images, and proceeding to a closer examination of the meaning of the time (Inayatullah, 1993). The motivation of this work is to analyse these methods of producing images, and the aim to enlarge the framework of these images, including the sustainable dimensions of Sachs (Sachs, 2002).

The methodology is to establish a cross-disciplinary work (Kochelmans, 1979), linking concepts from different disciplines. Having a conceptual base, it will be possible to propose a sustainable perspective to be added on the methods used to produce images. Then, an application is presented to test the new scenarios framework; that being scenarios for the biodiesel industry in Brazil, with the horizon until 2030.

It is quite common that energy scenarios often have economic growth and technological advances as frameworks for the future images. However, new approaches are already being used. World Energy Council produced the World Energy Scenarios for 2050, with a sustainable approach, to address the energy trilemma ${ }^{15}$ of achieving environmental sustainability, energy security and energy equity. The group of five variables were economics

\footnotetext{
${ }^{14}$ Even though methods and techniques have different meanings, in scenario literature, they are used interchangeably. Thus, in this work, they are assumed as the same.

${ }^{15}$ Energy trillema derives from the triple bottom line of sustainability: economically feasible, socially just and environmentally correct.
} 
and finances and trade, resource availability, energy systems and technologies, consumer behaviour and acceptance, government policies (WEC, 2013). The same method was use for design New Zealand Energy Scenarios (WEC, 2015a). Also based on energy trilemma, National Grid in UK proposed a new approach for the UK Energy Scenarios. They choose as base of the scenarios, Prosperity (counting the factors economic, political, technological, social and environmental) and Green ambition (Nationalgrid, 2015). Mont et al. (2014) present normative scenarios with dimensions of uncertainty, for new European Lifestyles models, in order to provide sustainable visions of lifestyles and consumption patterns in Europe for 2050. The driving forces were Technology and Social aspects (Mont, Neuvonen, \& Lähteenoja, 2014).

Thus, some advances have been made to use variables different from the traditional STEEP - social, technological, economic, environment and politics. However, a formal structure has not been proposed to include the sustainability dimensions of Sachs (2002). The contribution of this work is to provide a theoretical base to enlarge the usual framework that is utilised as driving forces and critical uncertainties. It is done by linking knowledge to better understand images construction; and making a proposal for the addition of new dimensions as frameworks for images, thereby exiting the economic growth paradigm. In order to reinforce the proposition, an application of the biodiesel scenarios in Brazil is shown. The key assumption is that by modifying the methods, the outputs can be images of the future that are more sustainable. This is valid for the methods that produce normative and exploratory scenarios, because they focus on desirable future situations and how they can be achieved (Börjeson et al., 2006; Durance \& Godet, 2010). Also because normative scenarios are expressions of human values (Durance \& Godet, 2010) on which it is assumed that it is possible and necessary to interfere in the future in order to have a more sustainable world.

The results of the work are: a method to develop scenarios with dimensions of sustainability and the application of the Brazilian biodiesel industry including sustainability aspects in the driving forces.

\subsubsection{Methodology}

The analysis was made based on Bishop's classification (Bishop et al., 2007) for scenario methods. Even though other classifications are mentioned eventually in the present work, it is important to clarify outright the methodological choice made. Consequently, this means that the final proposition of this work may not be applied to other classifications. 
Bishop (Bishop et al., 2007) classified the methods and techniques of producing scenarios in eight groups (Figure 17) . The most used techniques are in as "dimensions of uncertainty" that includes the Intuitive Logics and "La prospective" methods (Amer et al., 2013; Bradfield et al., 2005). The interest in those methods is justified because the dimensions of uncertainty are used to analysed the macro-environment (Pillkahn, 2008a), and they are the bases of the pictures drawn as images of the future, i.e. scenarios. The assumption is: by modifying those dimensions, the images of the future they produced can be modified. The Figure 17 points out the object of this work, according to Bishop's classification.

It was necessary to carry out a cross-disciplinary work (Kochelmans, 1979) in the sense of employing insights, methods, techniques or concepts from different disciplines to solve a problem without integrating them in a new discipline. There are three linking points essential for connecting the concepts and building the conceptual framework to develop the images of the future.

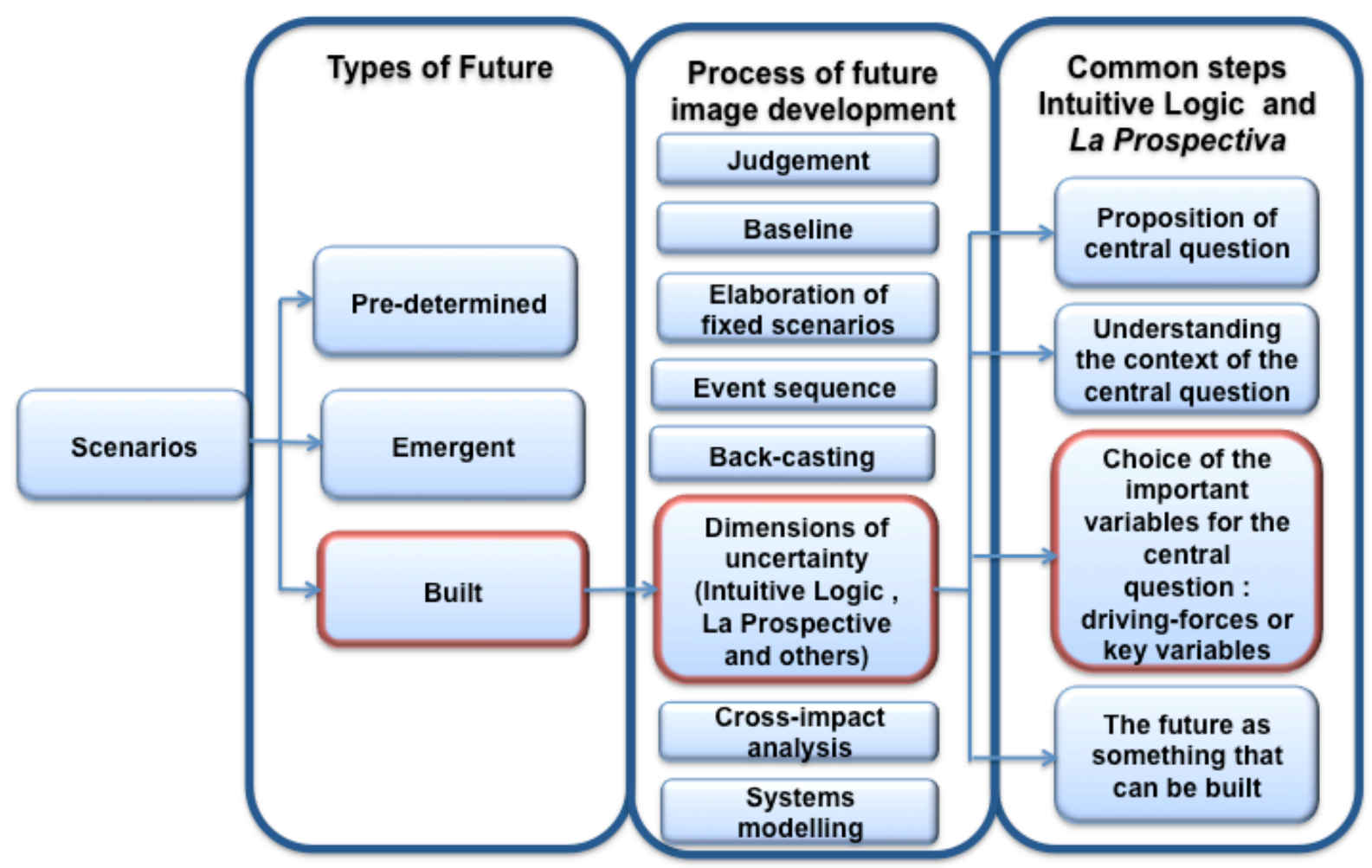

Source: elaborated by the author based on (Bishop et al., 2007; Börjeson et al., 2006; Bradfield et al., 2005; Durance \& Godet, 2010)

Figure 17 - a resumed classification of the methods to develop scenarios

The first point of linkage is the assumption that the scenarios methods reproduced the classical economic model. This is supported essentially by the most common image used in 
scenarios studies is business as usual. Therefore the critiques to the economic model can justify the need to change the way people and institutions think and plan about the future.

The second linking point was supported by Mintzberg studies about how people design strategies for the future in the Cognitive School Strategy (Mintzberg, Ahlstrand, \& Lampel, 2000). According to the author, mental maps and cognitive frames of reference are connected to an understanding that by changing the frames of reference, the mental maps will change.

Finally, the last linking point is to use the sustainable dimensions of Sachs (Sachs, 2002) to propose new dimensions of uncertainty in order to change the mental maps and, consequently, the images of future.

Then, an application was carried out to choose the driving forces for biodiesel scenarios in Brazil. Through an in-depth interview, Sachs' dimensions (Sachs, 2002) were introduced in the discussion about what would interfere in the future of the industry. The interview held with individuals ${ }^{16}$ was semi-structured and were initiated with the question: "what could influence/change the biodiesel industry for 2030". Afterwards, the interviewees were asked about Sachs' dimensions of sustainability: social, cultural, ecological, environmental, territorial, economic, National political (includes the dimension institutional), International political, and technology (Sachs, 2002), including the findings of a previous study of simulation of the biodiesel production (Dias, Bentsen, et al., 2015). The interview guide can be seen in Annex II. The interviews were typed and recorded. Then the answers were analysed and summarized in three categories:

1) What the interviewees though will interfere in the future of biodiesel industry;

2) What the interviewees though could interfere; and

3) What the interviewees though will not interfere in the future of biodiesel industry.

For example of the first group, what will interfere in the biodiesel industry is the economic activity. It is known that the fuel consumption is directly related to the economic activity. However, the variation in the economic growth will not interfere in the mandate. Since the good transport is based on road, it will be hard to think that, by 2030 , the biodiesel consumption would decrease. As an example of the third aspect, something that will not interfere in biodiesel consumption is the excess of oil production in Brazil, or the oil price. It was almost a consensus that these facts will not cause a decreasing in biodiesel mandate. The reason is the health benefits due to the decrease of air pollution. All the aspects classified in the second group were analysed if they could have polarized trends. If so, the aspect was a candidate to be a critical uncertainty. Different people pointed out distinct

\footnotetext{
${ }^{16}$ Out of 34 interviewed people, just 2 of them were interviewed in pairs.
} 
aspects, according to their background. However, since the first interviews, it was possible to identify that the land occupation was an uncertainty. In order to have a comprehensive vision, a composed uncertainty was proposed to be the base of the storylines.

\subsubsection{Target audience}

As a qualitative research, it does not require a large number of elements to be part of the sample. But it does require an intentional sample, choosing main stakeholders in the market. The target audience composed by 33 people from 23 organizations, including representatives of the market players and the government sector, such as, producers, dealers, workers, and organs of government that interfaces or contribute to the strategic guidance of the PNPB (the acronym for the Brazilian Biodiesel Program), namely, MME Ministry of Mines and Energy, MAPA - Ministry of Agriculture, Livestock and food supply, MDA - Ministry of Agrarian Development, the Ministry of Science, Technology and Innovation, the Ministry of development, industry and foreign trade, the Coordination of the National Program, the regulatory agency named ANP - National agency for petroleum natural gas and biofuels, EPE - the Brazilian energy research company, and EMBRAPA the Brazilian research company for agriculture and livestock. Also, Congressman who is Representative of the Parliamentary commission for biodiesel was interviewed. Additional sources, based on suggestions made during interviews were aggregated. The interviews start on October 2013. But most of them occurred from June to August 2015. The choice of the target audience was based on the productive chain of biodiesel according to Castro \& Lima (2010) and Martins et al. (2011). The complete list of the interviewees can be seen in Annex III.

\subsubsection{Analysis and discussion of the theoretical basis and the practical application}

\subsubsection{First linking point: the model of economic growth and scenarios methods}

Whereas the methods for scenario construction have been developed over the last 60 years, the perceived reality was, and still is, shaped by the rationale of the classical model of economic growth. Organizations were conceived in this model and are struggling to survive within it. What is envisioned as good solution is always based on continuous economic growth. It is quite natural because this has been the paradigm for the last 200 years. Likewise, the methods of constructing normative scenarios (the future we want) also tend to replicate this paradigm.

In simple terms, economic process is based on the transformation of raw materials into finished products, which are sold to people. A circular flow continues with the resources 
gotten from selling, being reinvested in improving production and so on. The economic process is seen as a cyclic process that preserves itself by production and consumption. Also, it is supposed to work as a closed system with the attributes of Newtonian mechanics: lawfulness, determinism and reversibility, which remains balanced primarily by the law of supply and demand. To the scarcity of raw materials, the answer is always to find substitutes, with more technology, or improving efficiencies in the process. Productivity can always be increased - doing more with less. This conception of continuous and reversible cycles is criticized by Georgescu-Roegen (1971) as a model based on the mechanistic paradigm, which is not accepted by physicists any longer (Georgescu-Rogen, 1971). The planetary stock of natural resources, matter and energy, is limited. Production processes significantly alter the environment, because they turns low entropy natural resources into high entropy products and waste, which is difficult or impossible to return to their initial (natural) state. Even though Georgescu-Roegen is sometimes contested (Floyd, 2007), there is no doubt that the depletion of natural resources and the generation of solid and thermal pollution are difficult to reverse. The waste products generated during the manufacturing process and after use, will accumulate in the environment irreversibly. Even if there is some method to quantify the monetary cost of reusing waste and restoring the environment, recover is not always or completely possible. Lost biodiversity barely is recovered. The internalization of "externality" neither resolves the pollution, nor recovers any mineral depleted. Elkington (Elkington, 1998) suggests that companies need innovative strategies which enables them to make a positive impact on the environment. In fact, economic processes are not cyclic, nor reversible. It is the direct application of the second law of thermodynamics - the law of entropy ${ }^{17}$. Every action of mankind, or any other body or any natural process results in a global system deficit (Georgescu-Rogen, 1971). In short, humanity is destroying its own habitat, making it impossible to have any steady-state equilibrium, because the planet is a closed system with finite resources (Georgescu-Rogen, 1971), and the pattern of consumption is much higher than the earth can support (Mont et al., 2014; WWF, 2014). It is the prisoner of a production model that hopelessly progresses to a disordered structure, a state of disorder. This leads to a state of maximum entropy, or heat death. Considering the economic process as a cycle, neglecting the finiteness of resources and the possible consequences of the decline of these resources, only the current generation has been favoured, but not the future generations. Therefore there are arguments to reduce

\footnotetext{
17 The entropy of a closed system continually (and irrevocably) grows, tending to a maximum; in other words, the available energy is transformed continuously in non-available energy, until to disappear completely.
} 
economic growth (Victor, 2010) or even to go backwards, i.e. degrowth ${ }^{18}$ (GeorgescuRogen, 1971; Latouche, 2007).

The report produced by Club of Rome (Meadows, Meadows, Randers, \& Behrens III, 1972) stated different results. Although it warned about the limits of economic growth, it proposed a state of equilibrium. But others (Daly \& Farley, 2004) later proposed a steady state and stopping of economic growth. Jackson recalling the ecological, technological, human and financial limits, criticizes the assumption of cycles in the economy (Jackson, 2009). The need for continuous economic growth is environmentally unfeasible, and the 2008 economic crisis proved that it is also economically unstable. Economic growth was supposed to bring prosperity, but in fact has increased inequality, even in OECD countries. Moreover, in the last century, the world economy doubled while it is estimated that $60 \%$ of ecosystems have been degraded (Jackson, 2009; Rockstrom et al., 2009). This situation becomes more severe when it is known that at least three planetary biophysical limits have been exceeded: global warming, species extinction and the nitrogen cycle (Steffen et al., 2015). As an example of the depletion of an important natural resource, since the early 1980s, the replacement volume of the oil reserves have been smaller than the planet has consumed (Vianna, Dias, Alves, \& Lopes, 2013). At this point, it is appropriate to question the prosperity vision built on continuous economic growth, and look for alternative visions in which humanity can still flourish and reduce their material impact on the environment (Jackson, 2009). Building scenarios of the future should bring alternatives to the economic growth. However, the visions of the future, or scenarios, follow approximately four archetypes (Dator, 1979), where the most common is the "continued growth" or business as usual:

a) Continued growth: in this future, it is assumed that current conditions and trends are enhanced;

b) Steady state: this future seeks to arrest growth and find a balance in the economy and with nature. It highlights a balanced, softer and fairer society;

c) Transformation: this future tries to change the basic assumptions of the other three. It comes out either through dramatic technological or spiritual change;

d) Collapse: this future results as continued growth fails and there are great contradictions.

Indeed, in the business as usual scenario, the images of the future are massed ${ }^{19}$, colonized by capitalist tradition (Inayatullah, 2008). It's like the idealized future had been already used by others. For example, despite the numerous problems identified with the urbanization and growth model in Western cities, the mayors insist on following the same

\footnotetext{
${ }^{18}$ Decroissanse in French

${ }^{19}$ done or occurring on a large scale.
} 
path of conurbation and overcrowding (Inayatullah, 2008). The worldview of the Industrial West is also criticized by Slaughter (Slaughter, 2002), arguing that far from bringing peace and universal prosperity, the model that is followed is leading directly into the abyss, because it does not provide a sustainable future for humanity. The trend expressed in the businessas-usual outlooks is truly dangerous (Jackson, 2009; Slaughter, 2002). Therefore, it is necessary to examine how the images are built looking for a way to change them and have a stronger image to provide an alternative to business as usual.

\subsubsection{Second linking point: strategies, mental maps and frames of reference}

According to Mintzberg, people have images of what they think reality is; like maps, where they choose the paths to the future or the strategies (Mintzberg et al., 2000). When people develop scenarios in groups, they shared their mental maps, or their mental models about what reality is (Van Der Heijden, 2005).

As a geographical map that represents the territory, but it is not the territory, the mental maps are representations of people's perception of reality. The maps include learning, interactions, beliefs and values of the people consolidated into their mental maps (Van Der Heijden, 2005; Wack, 1985), (as in a geographic map - geographic land marks, cities and so on) and the interrelation between them (like roads, rivers etc.).

Mental maps are also used to organize information and knowledge (Mintzberg et al., 2000), providing a reference point, a place to start (Weick, 1990). In practical terms, maps also have limits, or frames; otherwise it would be difficult to define what is in or out of the map. Indeed, frames of reference are structures used by people to sort out what it is reality and what is not, similar to frames in a picture that separates the content to be covered (within the frames) from that of what is not important (to the wall around the frame) (Bateson, 1972).

El Sawy and Puchant (1988) conducted an experiment using psychological frames of reference. They tested the dynamic adjustment of the thinking boundaries of a group while discussing future uses of cell phones. One of the conclusions of the experiment was that when some information about the external environment or about a possible future use of the product was not according to the frames of the group, one of the following alternatives occurred: either the information is discarded, or the frames were modified to integrate the information. The practical result was that changing the frames, different possibilities were included in the design of the future scenarios. Similarly, when geographical map frames are changed, more or less area can be inside the boundaries. In other words, to consider any information as valid, it is necessary to consider in which context (or mental map) it is located. This confirms the existence of frames of reference as framework of the possibilities that 
people can see as images of the future. It also shows that the framework can be changed by new information or facts (El Sawy \& Pauchant, 1988).

Developing scenarios using a set of variables as starting point for future images is, indeed, choosing the framework to define what will be considered valid or not for the process of building the images. Therefore, the driving forces and key variables or dimensions of uncertainty (Bishop et al., 2007), are frames of reference for the scenarios. It means that if something is not part of this set, it will not be seen as relevant to be compared with the mental maps. On one hand, this is positive because it helps to focus the attention. On the other hand, it is likely to limit perception of innovation or surprising facts (wildcards) that are not inside the frames.

\subsubsection{Third linking point: dimensions of uncertainty and dimensions of sustainability}

The set of methods that utilize "dimensions of uncertainty" includes the Anglo-American School of scenario planning also known as Intuitive Logic, and the French School called La prospective (Bradfield et al., 2005).

Wilson, a representative of the Intuitive Logic, explains the driving forces in the STEP formula are social, technological, economic, and political trends, which are used to analyse the possible uncertainties for the future (Wilson, 1998). In addition, he exemplifies ten categories as shown in Table 15, as necessary to form a comprehensive framework for analysing the environment for building scenarios. Most recently, "Environmental" was added (Bradfield et al., 2005; Schwartz, 1996) to the STEP formula, turning it into STEEP, without having a formal definition of the meaning. Van der Heijden (Van Der Heijden, 2005) not only uses the STEEP formula, but he recommends an analysis of the market and the industry structure in which the organization operates. He also recommends using the competitive forces of Porter (Porter, 1980). Pillkahn notes that sometimes the STEEP formula broadened by adding L -law, and V -values, (Pillkahn, 2008a). In sum, the Intuitive Logic School uses the set of variables STEEP to choose the ones that will be the structure of the future images, sometimes added by other variables, which vary depending on the author.

La Prospective school uses as key variables, demographic, economic, technological, social and organizational factors (Table 15) to decompose the global system that is being analysed (Durance \& Godet, 2010; Godet \& Durance, 2011), but eventually other issues may emerge from the developing scenario group. After this, the chosen variables will be combined to form future images.

For both schools, the choice of the driving forces or key variables (dimensions of uncertainty) restricts the set of uncertainties that may be relevant for the development of 
scenarios. Thus, the dimensions of uncertainty form, actually, a frame of reference, giving support and direction to the images that are going to be the scenarios.

It is quite natural that the reality, which is usually in our mental maps, is attached to the economic model discussed in 3.1, because this has been the valid paradigm for the last 200 years. Likewise, the methods of constructing normative scenarios (the future we want) also tend to replicate this paradigm. However, Jackson (Jackson, 2009) considers there may be prosperity without economic growth. Sachs (Sachs, 2004) suggests consider a broader development concept instead of economic growth in order to promote equality and poverty reduction, without compromising natural resources irreversibly for future generations. In this reasoning, Latouche makes suggestions on how to proceed to degrowth, gradually and distinctly, respecting current regional needs (Latouche, 2007).

Table 15 - list of variables considered for uncertainty analysis

\begin{tabular}{|c|c|c|c|c|c|}
\hline \multicolumn{6}{|c|}{ Dimensions of uncertainty } \\
\hline & & Logic Intu & tive & & \\
\hline $\begin{array}{l}\text { Usual } \\
\text { SEPT: } \\
\text { social, } \\
\text { economic, } \\
\text { political, } \\
\text { and } \\
\text { technologi } \\
\text { cal }\end{array}$ & $\begin{array}{l}\text { Wilson } \\
\text { Demographic } \\
\text { patterns, social and } \\
\text { lifestyle factors, } \\
\text { economic } \\
\text { conditions, natural } \\
\text { resources, physical } \\
\text { environment, and } \\
\text { political forces, } \\
\text { regulatory technological } \\
\text { forces, international } \\
\text { relations, market } \\
\text { forces, competition }\end{array}$ & $\begin{array}{l}\text { Schwartz } \\
\text { SEEPT: social, } \\
\text { economic, } \\
\text { environmental, } \\
\text { political, and } \\
\text { technological }\end{array}$ & $\begin{array}{l}\text { Van der Heijden } \\
\text { SEEPT: social, } \\
\text { economic, } \\
\text { environmental, } \\
\text { political, } \\
\text { technological, } \\
\text { structural analysis of } \\
\text { the industry and the } \\
\text { market, competitive } \\
\text { forces of Porter: } \\
\text { competitors, } \\
\text { suppliers, buyers, } \\
\text { potential new entrants } \\
\text { and substitute } \\
\text { products }\end{array}$ & $\begin{array}{l}\text { Ulf Pillkahn } \\
\text { SEEPTLV: } \\
\text { social, } \\
\text { economic, } \\
\text { environment } \\
\text { al, political, } \\
\text { technological } \\
\text {, law, values }\end{array}$ & $\begin{array}{l}\text { Godet,Durance } \\
\text { demographic } \\
\text { economic, } \\
\text { technological , } \\
\text { social and } \\
\text { organizational }\end{array}$ \\
\hline
\end{tabular}

Source: prepared by the authors based on Wilson(Wilson, 1998), Schwartz(Schwartz, 1996), Van der Heijden (Van Der Heijden, 2005), (Pillkahn, 2008a), Godet(Godet \& Durance, 2011)

By choosing future image based on the STEEP variables, with or without the competitive forces of Porter, models of welfare by increasing technology and consumption are reproduced, without criticism. Consequently, inequality, environmental degradation and depletion of natural resources are more likely to be perpetuated (Piketty, 2014), i.e. the scenario construction methods still assume the neoclassical economic model for which 
continued growth is imperative. Eventually, the mental maps may change, but within the same limits, the same framework, which may be preventing people from seeing long plains or chasms in the next steps. The logical deduction is that it is necessary to change the frames of reference to allow for different possibilities to be included in the scenarios, like the experiment conducted by El Sawy and Pauchant (1988), mentioned in section 3.2.3.2.

Slaughter (2002) suggests that in order to be closer to reality, the driving forces include technical dynamism along with scientism, materialism, commercial exploitation (for profit by multinational organizations, banks, etc.) nationalism (the military-industrial complex in behalf of), colonialism, greed, short-term thinking, ego, fear of death, and the defects in the western industrial worldview, particularly short-term thinking and the hegemony of instrumental rationality (Slaughter, 2002). Nevertheless, the author does not formalize the inclusion of social and environmental dimensions. The design of a future that considers future generations must not ignore the harmonization of social, environmental and economic objectives. For this, Sachs (2002) suggests the use of eight criteria to which technology is added to replace the STEEP formula. For almost all of them it is possible to have measures and indicators in order to be considered as variables:

- Territoriality, which includes:

- Relationship between rural and urban sites

- Improving urban environment

- Overcoming inter-regional disparities

- Strategies of environment development for ecologically fragile areas (biodiversity for eco-development)

- Culture, detailed by:

- Tradition and innovation

- National autonomy

- Self-confidence / openness to the world

- International politics:

- Prevention of war, guarantee of the peace, promotion of international cooperation, north-south co-development

- Effective control of the international financial system and business

- Effective control of the application of the precautionary principle

- Prevention of negative global changes, protection of biodiversity and cultural diversity and management of global heritage

- National politics:

- Democracy and appropriation of universal human rights 
- Economics, including minimum conditions of survival for the people involved ;

○ Inter-sectorial balanced economic development

- Food safety

- Continue capacity of modernization (production scientific and technological research)

- Sovereign insertion in the world economy

- Social, considering:

- The future generations welfare,

- Social homogeneity

- Income distribution

○ Full employment, decent quality of life

- Equal access to resources and social services

- Environmental, respecting and enhancing the capacity of self-regeneration;

- Ecologic, including:

- Preservation;

- Limitation of the use of non-renewable resources.

The reason of including Sachs dimensions as an initial set of driving forces is to enlarge the frames of reference and then, to make possible the imagination of a future where the economic growth is no longer the most important driver. Keeping in mind that the future is for the next generations, all the aspects namely economic, environment, ecological, territorial, cultural, social, national political, international political, and technology must support the social development, which in turn, must be economically viable without depleting all the resources. An example of this can be seen on the creation of the Grameen Bank (Yunnus, 2001). Without given up the economic gain, a social development was largely promoted in this experience.

Business as usual scenarios should be thought in a negative way, once it has depleted the natural resources and increased social inequalities. Instead, other kind of scenarios would be built without having the economic growth as the main driver. Moreover, the enlarged framework can increase futures initiatives like responsible consumption (Marchand \& Walker, 2008), can provide support for future investments in R\&D for sustainable products, and framework for discussions like Green growth versus Green economies (Lorek \& Spangenberg, 2014). Indeed, long-term perspective is necessary to prepare the future. The future would be likely more sustainable if those perspectives were built into broader frameworks than just economic cycles. 


\subsubsection{Practical application: driving forces for biodiesel industry in Brazil, for 2030}

In order to test the new dimensions in a process of scenarios building, a practical application was performed, for the Brazilian biodiesel industry (with a horizon until 2030). Biodiesel is a biofuel used to replace mineral diesel, which some advantages are to reduce emissions and to improve energy access and energy security. The major producers in the world are Germany, the USA, France, Brazil and Argentina. Biodiesel is produced, in Brazil (2013), from soybean $(74 \%)$, beef tallow $(20 \%)$, cotton $(2 \%)$, and other fats $(4 \%)$ (ANP, $2015 b)$. The in-depth interview was preceded by a simulation of the national production, with linear programming models, to explore the possibilities of production, given the current land use in the country. The results of the simulation were part of a questionnaire that was applied in an in-depth interview, with select audience, as mentioned in methodology section (3.2.2).

As a result of the simulation (Dias, Bentsen, et al., 2015), some aspects emerged as possible driving forces to change the future. They were classified according to the Sachs dimensions (Sachs, 2002) Table 16.

Table 16 - Driving forces that resulted from the simulation model

\begin{tabular}{lll}
\hline \multicolumn{1}{c}{ Insights from simulations study } & Sachs dimensions \\
\hline Diversification of the feedstock, de-concentration of the supply market & Economic \\
\hline Regionalization of the production, including the poorest region in the Social, territorial \\
energy market
\end{tabular}

Source: elaborated from the author, based on (Dias, Bentsen, et al., 2015)

To these aspects, others were added to compose the questionnaire of the in-depth interview, to complete the Sachs dimensions. They are shown on Table 17. 
Table 17 - Driving forced added to questionnaire

\begin{tabular}{|c|c|}
\hline Driving forces added & Sachs dimensions \\
\hline Technological advances in fuels, engines, and biodiesel production & Technological \\
\hline Land grabbing, land titling & $\begin{array}{l}\text { Social, territorial, National } \\
\text { political }\end{array}$ \\
\hline International pressure against the Amazon deforestation & International political \\
\hline Price of oil, the new Brazilian proven reserves - the pre-salt. & Economic \\
\hline Public health & Social, economic \\
\hline Policies and regulation & $\begin{array}{l}\text { National } \\
\text { institutional }\end{array}$ \\
\hline $\begin{array}{l}\text { Include regional oilseeds like babassú, macaúba (using degraded and } \\
\text { marginal land), or other like peanuts as feedstock }\end{array}$ & $\begin{array}{l}\text { Social, economic, } \\
\text { territorial, cultural }\end{array}$ \\
\hline $\begin{array}{l}\text { Include palm oil as feedstock (there is a National program for restoring } \\
\text { degraded land in Amazon biome using Palm oil) }\end{array}$ & $\begin{array}{l}\text { Social, } \\
\text { territorial }\end{array}$ \\
\hline
\end{tabular}
Source: Elaborated by the author.

The audience was asked if any of the items in (Table 16 and Table 17) would change the future or would be an uncertainty in the future of the biodiesel industry, for 2030. As a semi-structure questionnaire, the interviewees would add more aspects, if they consider relevant. The lack of social capital, for example, was not part of the questionnaire, but one interviewee raised the aspect. However, the others said that it would be not relevant. The summary of the interviews was classified in three groups, as follows:

1) Driving forces that are uncertainties, meaning the variables whose different trends could impact the biodiesel industry in different ways:

a) Deforestation of the Amazon and MAPITOBA ${ }^{20}$ states, and its impact;

b) The progress of the land regularization in Amazon region - Terra Legal (land titling);

c) Restoration of the degraded land;

d) Diversification of feedstock oilseeds (palm oil, peanuts, babassú, macaúba, others) and residues (animal fats and waste cooking oil);

e) Inclusion of small farms,

f) Technological advances.

2) Driving forces that are not uncertainties, but they will affect the biodiesel industry, e.g. there is no doubt about them, they are already pre-determined. These factors will cause positive impact in the biodiesel industry:

a) Reduction of emission, especially in the cities;

\footnotetext{
${ }^{20}$ MAPITOBA are the acronyms for the States of Maranhão, Piauí, Tocantins and Bahia. They are located on North and Northeast regions, where the Cerrado biome predominates
} 
b) The need for decreasing health problems caused by diesel pollution.

3) Driving forces that could have different trends but it will not affect biodiesel industry (according to the interviewed): the international oil price, the proven Brazilian oil reserves, and international pressure on environmental policies. The reasons were that nobody doubts the environmental advantages of biodiesel; neither do they feel that the oil prices nor the Brazilian pre-salt oil reserves can reverse the mandatory blend of the biodiesel. Also, there does not appear to have the belief that external pressures can change the environmental policies regarding biodiesel, feedstock, and deforestation.

\section{Critical uncertainties}

The aspects pointed out in the first group of variables (driving forces that are uncertainties. Items 1.a to 1.c) concern the expansion of agriculture frontier in Amazon biome and MAPITOBA states. These areas have been the stage of a complex and conflicting situation. The Amazon Forest is world's largest rainforest; it has the largest river basin on the planet and the biggest hydroelectric potential left in Brazil. Also, it probably harbours $10 \%$ of the world's known species and contains $10 \%$ of the global reserve of carbon stored in its diverse ecosystem. The forest is home to 34 million people, including 385 indigenous groups (Macedo \& Castello, 2015; Maretti et al., 2014). There are on-going disputes regarding territories for indigenous reserve, traditional communities, illegal logging, land grabbing, small farmers and big companies, just to mention few.

Expanding the agricultural area in Brazil, without worsening this conflicting situation, will require the effectiveness of the Government policies regarding deforestation control, land occupation, and restoration of degraded land. However, the policies to increase afforestation and to promote restoration of the degraded land may not be effective whilst there is cheap land available, which is result of uncontrolled deforestation. Summing up, if all policies do work, the expansion of agriculture area will happen by converting land that is not protected, but it will also utilize degraded and marginal land. The utilization of marginal and degraded land can be an opportunity to diversify the biodiesel feedstock, since there are oilseeds adapted to these lands, such as macauba, babassu, pequi and so on. Once they require more labour force than the mechanized crops, it will also be an opportunity to social inclusion through the generation of jobs.

On the other hand, if there is still space for illegal logging and land grabbing, the cleared areas will continue to be a cheap land ready to be occupied by cattle or commercial agriculture. The reason is that so far, illegal logging, cattle and commercial agriculture are 
the most common drivers of deforestation (Hosonuma et al., 2012; Nepstad, Stickler, \& Almeida, 2006). Hence, biodiesel feedstock is more likely to continue to be soybean and beef tallow.

Based on this context, the composed critical uncertainty was called response to climate change and environment conservation. This is understood as the level of commitment of the Brazilian Government to fulfilling international agreements concerning climate change, which would lead to the control of deforestation, the restoration of degraded land all over the entire country, and the progress of National Program of land titling (Terra Legal) in Amazon biome. Notice that, once the interviewees sad that the international pressure on stopping deforestation would not affect the Brazilian National policies, this "response" is about the voluntary measures taken regarding climate change and environmental conservation. The rationale and the consequence of Government policies can be seen in Figure 18

The diversification of biodiesel feedstock (item 1.d) was considered to be a consequence of the government policies and could also be favoured by the result of the items 1.a, 1.b, 1.c. the item "e" inclusion of small farms also depends on policies and is more likely to happen with diversification.

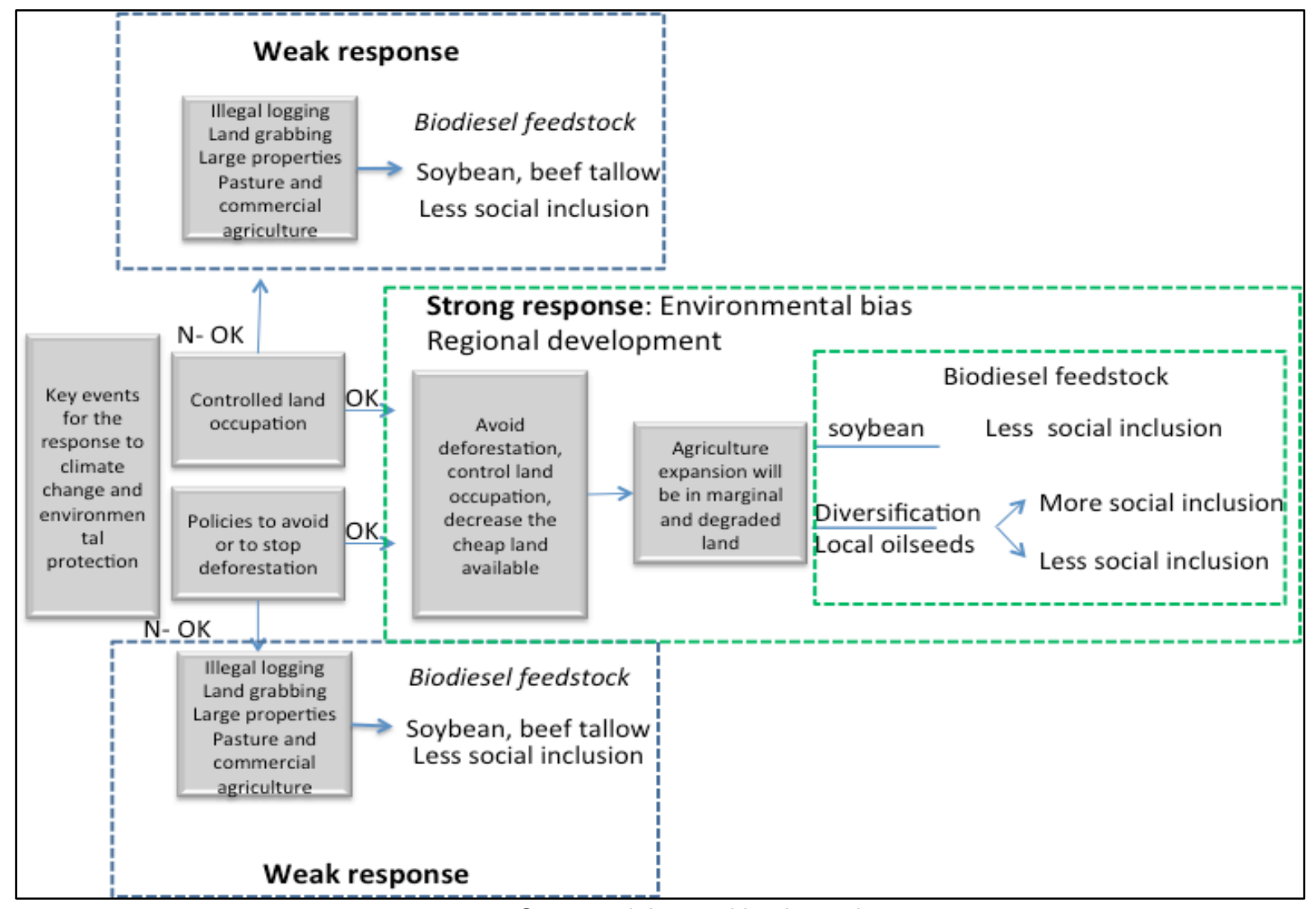

Source: elaborated by the author

Figure 18- the cause-effect relationship in the critical uncertainty level of response to climate change and environmental conservation. 
Adding technological advances (item 1.f) onto the above-mentioned uncertainty there are critical uncertainties for the future possibilities to produce biodiesel in Brazil, by 2030.

The framework for the scenarios is shown on Figure 19. The two critical uncertainties form the axes of the $2 \times 2$ matrix (or Cartesian coordinates). The signal "+" in vertical axis represents strong response to climate change and environment conservation. Combining all assumptions for this uncertainty a strong response for the three aspects would mean all measures to avoid deforestation, to restore degraded land, and to control the occupation of land in Amazon biome are taken. The signal "“" in vertical axis represents weak response to climate change and environment conservation. In this case, it was assumed that the measures needed were not taken or they did not have the expected result. Moreover, it was assumed that deforestation in the Amazon biome and MAPITOBA ${ }^{21}$ states will continue in protected and non-protected land indiscriminately.

The extremes in the horizontal axis are gradual advances in biodiesel feedstock and production at one end and technological breakthrough in fuel and engines at the other. The speed of the technological advances will be assumed to be gradual. The exception is the quadrant four where the neglected effects of not protecting the environment bring economic problems, which to not allow investing in new fuel technologies.

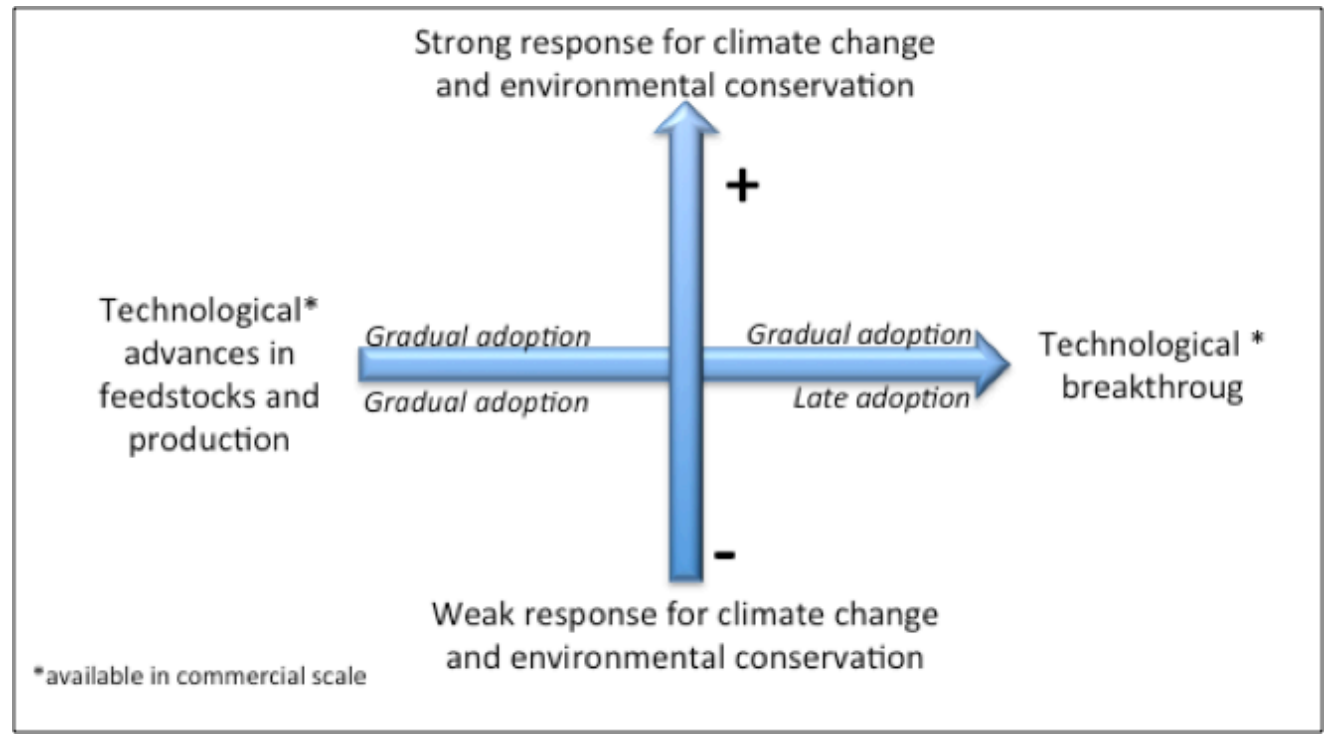

Source: elaborated by the author

Figure 19 - The framework for the biodiesel scenarios by 2030

The combination of the critical uncertainties into the scenarios is shown in Figure 20. Briefly, the storylines of the scenarios are as follows:

\footnotetext{
${ }^{21}$ Acronyms for the states Maranhão, Piauí, Tocantins and Bahia
} 
a) I - BUSINESS AS USUAL (BAU): this scenario assumes that the dynamics of doing business in the biodiesel industry continue to be the same, with gradual adoption of new technologies of producing biodiesel and delays in protecting environment and recovering degraded land. Therefore, by 2030 the biodiesel production still uses vegetal oils and animal fat. Other feedstock and/or production technology will have a small share of the market.

b) II - STEP BY STEP (SBS): gradual adoption of technological advances (like in BAU scenario) and focus on native vegetation protection. Recovery and use degraded land will make possible the inclusion of local oilseeds as biodiesel feedstock. This will change the industry dynamic promoting regional development and more social inclusion. The diversity of feedstock and land availability will make it easier to have the large-scale exports

c) III- ABUNDANCE (ABC): technological breakthrough will be commercial available, like hydrogen and fuel cells. By 2030 developed countries will have started to employ them. In Brazil, where degraded lands have been restored and the Amazon rainforest have been full protected, the biodiesel production will be plenty. However the production is strictly to internal consumption, because developed countries will not import biodiesel. Brazil will have time and available funding to start innovation plans.

d) IV- SCARCITY (SCR): there will be a technological breakthrough like in $A B C$ scenario. However, delays in protecting the environment and recovering degraded land, added to water and climate stress will worsen the Brazil's socioeconomic conditions. This situation won't allow the adoption of new technologies and can lead to a scarcity of biodiesel.

It is possible to see that the prosperity can happen in scenarios II- Step by step (SBS) and III- Abundance $(A B C)$, brought by the care of environment that in its turn may provide options for social inclusion. On the other hand, the continuous deforestation in scenarios I Business as usual (BAU) may not bring social inclusion once the deforestation is linked, so far, to large proprieties (Godar, 2014), mechanized and highly technological agriculture (Frederico, 2012). The scenario IV-Scarcity (SCR) may occur, it would mean repeating situations of civilization collapse, such as the case of Easter Island and The Mayas, because, among other things, they did not take care of their environment (Diamond, 2011).

\subsubsection{Conclusion}

The main idea of this work was to enlarge the frames of reference, thereby allowing new ideas to come in and provide alternatives so that the future generations can have still a 
bearable world in which to live. It is also an attempt to contribute and improve the body of knowledge referred to as Future Studies.

As it was expected, the compound critical uncertainty was the result of the enlarged initial framework STEEP added by Sachs's dimensions (2002). It provided more comprehensive vision of the reality where it was possible to perceive the interrelationship between the variables. Also, it was possible to develop sustainable options for the future, that are Step by Step and Abundance scenarios. These options were developed because the mental maps were pushed to see beyond the business as usual. It means that intergenerational solidarity will more likely to be in the images of the future if the frameworks are enlarged.

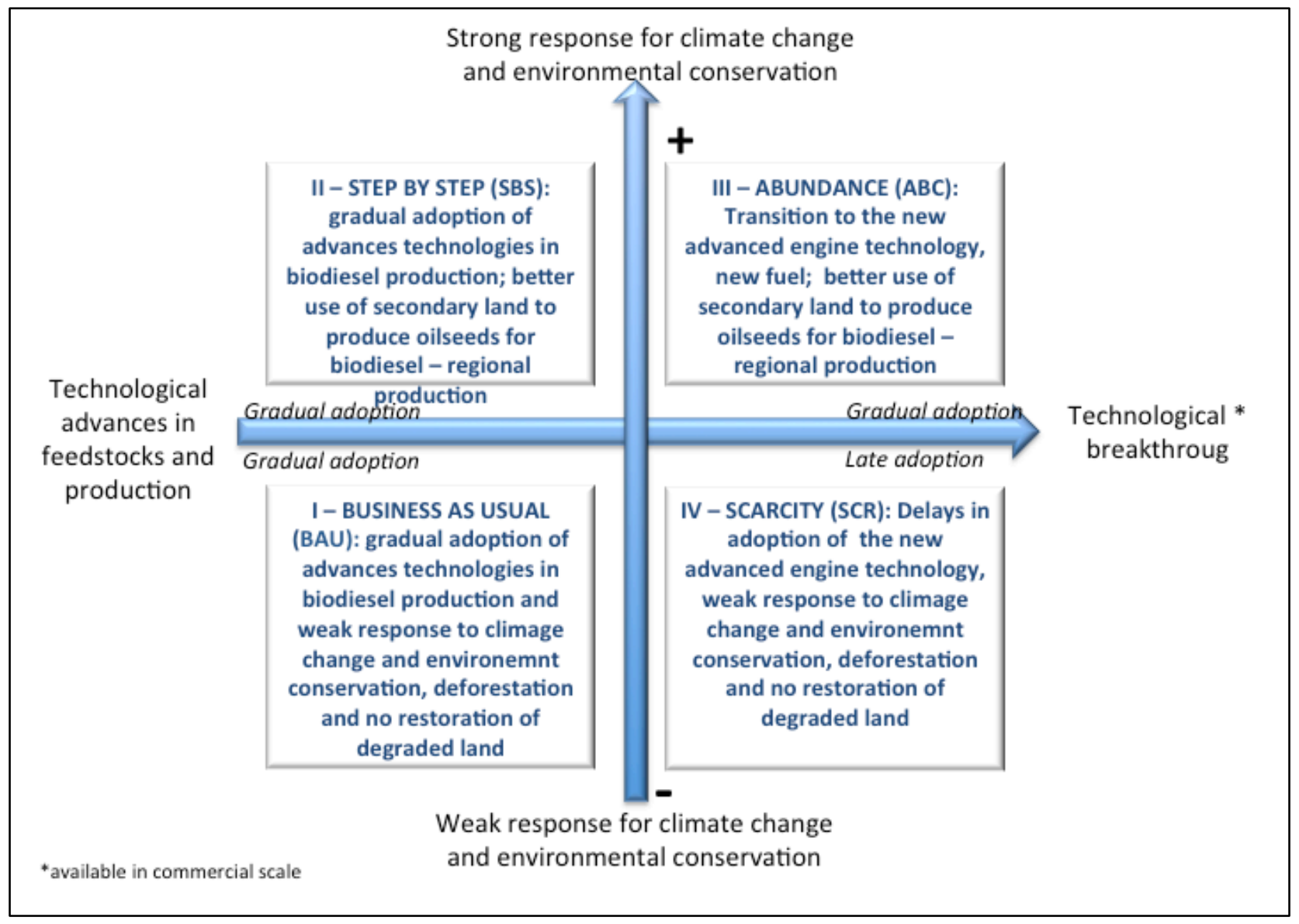

Source: Elaborated by the author

Figure 20 - Framework and the Scenarios for biodiesel production, by 2030

If the scenario images continue to be produced based on the economic cycle, the future will follow business as usual dynamics. Hence, it will not be sustainable as it has not been thus far. That is why the proposition of this work makes sense for the normative and 
exploratory scenarios, because they are the future that is possible to build when it does not simply follow the trends of the past.

In order to develop different alternatives for the future, it is necessary to change the way the present is understood and perceived.

\section{Contributions}

Dias wrote the manuscript, Vianna supervised and made a critical review.

\section{Acknowledgments}

This work was inspired in the PhD class discussion about methodologies. So, the authors would like to thank the $2012 \mathrm{PhD}$ Center of Sustainable Development at University of Brasilia.

This paper was written as part of $\mathrm{PhD}$ research of the authors, and there was not special funding for this.

\subsubsection{References}

Amer, M., Daim, T. U., \& Jetter, A. (2013). A review of scenario planning. Futures, 46(0), 2340. doi:http://dx.doi.org/10.1016/j.futures.2012.10.003

ANP (2015). Biocombustíveis. Retrieved from www.anp.gov.br

Bateson, G. (1972). Part III- A theory of play and fantasy Steps to an ecology of mind (pp. 541). New York, USA: Ballatine Books.

Bishop, P., Hines, A., \& Collins, T. (2007). The current state of scenario development: an overview of techniques. Foresight, 9(1), 5-25. doi:10.1108/14636680710727516

Bradfield, R., Wright, G., Burt, G., Cairns, G., \& Van Der Heijden, K. (2005). The origins and evolution of scenario techniques in long range business planning. Futures, 37(8), 795-812. doi:http://dx.doi.org/10.1016/j.futures.2005.01.003

Börjeson, L., Höjer, M., Dreborg, K.-H., Ekvall, T., \& Finnveden, G. (2006). Scenario types and techniques: Towards a user's guide. Futures, 38(7), 723-739. doi:10.1016/j.futures.2005.12.002

Daly, H. E., \& Farley, J. (Eds.). (2004). Ecological Economics Principles and Applications. Washigton, USA: Island Press.

Dator, J. A. (1979). The futures of cultures and cultures of the future. In M. T., T. Ciborowski, \& R. Tharp (Eds.), Perspectives on Cross Cultural Psychology. New York: Academic Press. 
Diamond, J. (2005). The Viking prelude and fugues; NOrse Greenland's flowering; Norse Greenland's end Collapse: How society choose to fail or succeed. USA: Penguin Books.

Diamond, J. (2011). Collapse: how societies choose to dail or succed (revised edition ed.). USA: Penguin Books.

Dias, M. A. d. P., Bentsen, N. S., \& Felby, C. (2015). The choice of feedstocks for producing biodiesel: a case study of Brazil. PhD thesis chapter. Centre for Sustainable Development and Department of Geosciences and Natual Resources Management, section for Forest, Nature and Biomass. University of Copenhagen and University of Brasilia.

Durance, P., \& Godet, M. (2010). Scenario building: Uses and abuses. Technological Forecasting and Social Change, 77(9), 1488-1492. doi:http://dx.doi.org/10.1016/j.techfore.2010.06.007

El Sawy, O. A., \& Pauchant, T. C. (1988). Triggers, templates and twitches in the tracking of emerging strategic issues. Strategic Management Journal, 9, 455-473.

Elkington, J. (1998). Parnerships from cannibals with forks: the triple bottom line of $21^{\text {st }}$ century business. Environmental quality management(Autumn).

FAO, IFAD, \& WFP. (2015). The state of food insecurity in the world 2015. Meeting the 2015 International hunger targets: taking stock of uneven progress. Retrieved from Rome: www.fao.org/publications

Floyd, J. (2007). Thermodynamics, entropy and disorder in futures studies. Futures, 39(9), 1029-1044. doi:10.1016/j.futures.2007.03.011

Frederico, S. (2012). Agricultura científica globalizada e fronteira agrícola moderna no Brasil Confins on line, 17. doi:DOI : 10.4000/confins.8153

Georgescu-Rogen, N. (1971). The Entropy Law and the Economics Process Ed. Havard

Godar, J. e. a. (2014). Actor-specific contributions to the deforestation slowdown in the Brazilian Amazon. . PNAS, 111(43). Retrieved from www.pnas.org/cgi/doi/10.1073/pnas.1322825111

Godet, M., \& Durance, P. (2011). La prospective strategique - pour les entreprises et les territoires (2a. ed.). Paris, France: Dunod.

Inayatullah, S. (1993). From who I am to when I am. Futures, 235-253.

Inayatullah, S. (2008). Six pillars: futures thinking for transforming. Foresight, 10(1), 4-21. doi:10.1108/146366808 10855991

Jackson, T. (2009). Prosperity without growth? The transition to a sustainable economy. Retrieved from London: www.sd-commission.org.uk

Kochelmans, J. J. (1979). Why interdiscplinarity? . In J. J. Kockelmans (Ed.), In Interdisciplinarity and higher education. London: The Pensylvania State University Press. 
Latouche, S. (2007). Petit traité de la décroissance sereine (M. e. u. Nuits Ed.). France.

Lorek, S., \& Spangenberg, J. H. (2014). Sustainable consumption within a sustainable economy - beyond green growth and green economies. Journal of Cleaner Production, 63, 33-44. doi:10.1016/j.jclepro.2013.08.045

Macedo, M., \& Castello, L. (2015). The state of the Amazon: Freswater connectivity and Ecosystem Health. Retrieved from Brasilia: http://d2ouvy59p0dg6k.cloudfront.net/downloads/wwf_livingamazon_state_of_the_am azon_freshwaterconnectivity_links_web_eng.pdf

Marchand, A., \& Walker, S. (2008). Product development and responsible consumption: designing alternatives for sustainable lifestyles. Journal of Cleaner Production, 16(11), 1163-1169. doi:10.1016/j.jclepro.2007.08.012

Maretti, C. C., Riveros S., J. C., Hofstede, R., Oliveira, D., Chrity, S., Granizo, T., . . . Thompson, C. (2014). State of the amazon: Ecological representation in prtected areas and indigenous territories. Retrieved from http://d2ouvy59p0dg6k.cloudfront.net/downloads/final_report_11_11_14.pdf

Meadows, D., Meadows, D., Randers, J., \& Behrens III, W. W. (1972). The limits to growth a report for the club of Rome's project on the predicament of mankind (Vol. 1). New York, NY, USA: Universe Books.

Mintzberg, H., Ahlstrand, B., \& Lampel, J. (2000). Safari de estratégia - um roteiro pela selva do planejamento estratégico (N. M. Jr, Trans.). Porto Alegre, Brazil: Bookman.

Mont, O., Neuvonen, A., \& Lähteenoja, S. (2014). Sustainable lifestyles 2050: stakeholder visions, emerging practices and future research. Journal of Cleaner Production, 63(0), 24-32. doi:http://dx.doi.org/10.1016/j.jclepro.2013.09.007

Nationalgrid. (2015). Future energy scenarios - UK gas and electricity transmission. Retrieved from London, UK: www.nationalgrid.com

Piketty, T. (2014). Capital in the Twenty-first century (A. Goldhammer, Trans.). USA: Belknap Press.

Pillkahn, U. (2008). Detection- detecting and recording changes in the enterprise environment Using trends and scenarios as tools for strategy development- shaping the future of your enterprise. Erlang, German: Publicis Corporate Publishing.

Porter, M. E. (1980). Competitive Strategy, techniques for analysing industries and competitors. USA: The free press.

Rockstrom, J., Steffen, W., Noone, K., Persson, A., Chapin, F. S., Lambin, E. F., . . Foley, J. A. (2009). A safe operating space for humanity. Nature, 461(7263), 472-475. Retrieved from http://dx.doi.org/10.1038/461472a

Sachs, I. (2002). Caminhos para o desenvolvimento sustentável (2a. ed.). Rio de Janeiro: Garamond.

Sachs, I. (2004). Desenvolvimento includente, sustentavel e sustentado. Rio de Janeiro, Brazil: Garamond. 
Schwartz, P. (1996). The art of the long view: Planning for the future in an uncertain world. USA: Currency Doubleday.

Slaughter, R. (2002). Futures Studies as an intelectual and applied discipline. In J. A. Dator (Ed.), Future Studies in High education. USA: Praeger Publishers.

Steffen, W., Richardson, K., Rockström, J., Cornell, S. E., Fetzer, I., Bennett, E. M., ... . Sörlin, S. (2015). Planetary boundaries: guiding human development on a changing planet. Sciencexpress.

UNWATER. (2013). Water-cooperation 2013, facts and figures. Retrieved from http://www.unwater.org/water-cooperation-2013/water-cooperation/facts-andfigures/en/

Van Der Heijden, K. (2005). Scenarios - the art of strategic conversation (2a. ed.). UK: John Wiley \& sons, Ltd.

Varum, C. A., \& Melo, C. (2010). Directions in scenario planning literature - A review of the past decades. Futures, 42(4), 355-369. doi:10.1016/j.futures.2009.11.021

Vianna, J. N. d. S., Dias, M. A. d. P., Alves, A. S. H., \& Lopes, M. (2013). Opportunities and challenges for Biodiesel in the XXI century. In M. Lopes, T. L, I. Ribeiro, A. Monteiro, H. Martins, S. Rafael, A. I. Miranda, \& C. Borrego (Eds.), (Vol. 1, pp. 59-65). Aveiro, Portugal.

Victor, P. (2010). Questioning economic growth. Nature, 468(7322), 370-371. Retrieved from http://dx.doi.org/10.1038/468370a

Wack, P. (1985). Scenarios: uncharted waters ahead. Harvard Business Review(September 1985).

WEC, W. e. c. (2013). World Energy Scenarios: Composing energy futures to 2050. Retrieved from London, UK: https://www.worldenergy.org/publications/2013/worldenergy-scenarios-composing-energy-futures-to-2050/

WEC, W. e. c. (2015). New Zeland Energy Scenarios- navigating energy futures to 2050. Retrieved from New Zealand: https://www.bec.org.nz/projects/bec2050

Weick, K. E. (1990). Cartographic Myths in Organizations. In A. S. Huff (Ed.), Mapping strategic thoughts. New York, NY, USA: Jonh Wiley \& sons, Ltd.

Wilkinson, A. (2009). Scenarios practices: in search of theory. Journal of Futures Studies, 13(3), 107-114.

Wilson, I. (1998). Mental maps of the future: an intuitive logics Approach to scenarios. In L. F. R. M. Randall (Ed.), Learning from the future - competitive Foresight Scenarios. USA: John Wiley \& sons, Ltd.

WWF. (2014). Living Planet Report 2014, Species and spaces, people and places.

Yunnus, M. (2001). Banker to the poor: Oxford UNiversity Press. 


\section{ANNEX II: GUIDANCE FOR THE INTERVIEWS}

\section{Guide for the in-depth interviews}

Objective: Capture and register the perception of the participants regarding the drive forces for the biodiesel industry in 2030, i.e.: What can interfere in the future of biodiesel in Brazil, for $2030 ?$

Initially ask about the triple bottom line (social, environmental and economic aspects) and then go deeper in the eight sustainability dimensions of Sachs, related with the insights obtained in the linear programming model, the previous interviews, and recently facts, such as:

\begin{tabular}{llc}
\hline \multicolumn{1}{c}{ Insights from simulations study } & Sachs dimensions \\
\hline $\begin{array}{l}\text { Diversification of the feedstock, de-concentration of the supply } \\
\text { market }\end{array}$ & Economic \\
\hline $\begin{array}{l}\text { Regionalization of the production, including the poorest region in } \\
\text { the energy market }\end{array}$ & Social, territorial \\
\hline $\begin{array}{l}\text { Motivate deforestation, seeking for more arable land to expand the } \\
\text { production, and overcoming the environmental benefits of reducing }\end{array}$ & Environment, \\
emission & \\
\hline $\begin{array}{l}\text { Restoration of degraded land, once there are some oilseeds that } \\
\text { can grow in degraded and marginal lands, bringing much more }\end{array}$ & Ecological, \\
environmental benefits. Also can improve the income of the & \\
communities, valuing wasted land. & \\
\hline $\begin{array}{l}\text { Using more residues like animal fat and waste cooking oil, also } \\
\text { bringing much more environmental benefits; not competing with }\end{array}$ & Ecological, social, \\
food for land; making the production cheaper; and probably & \\
resulting in social benefits depending the way the waste cooking oil & \\
is collected. & & \\
\hline
\end{tabular}

\section{Driving forces added}

Technological advances in fuels, engines, and biodiesel production Land grabbing, land titling

International pressure against the Amazon deforestation

Price of oil, the new Brazilian proven reserves - the pre-salt.

Public health

Policies and regulation

Include regional oilseeds like babassú, macaúba (using degraded and marginal land), or other like peanuts as feedstock Include palm oil as feedstock (there is a National program for restoring degraded land in Amazon biome using Palm oil)
Technological

Social, territorial, National political International political

\section{Economic}

Social, economic

National political, institutional

Social, economic, territorial, cultural

Social, economic, territorial 


\section{ANNEX III LIST OF PARTICIPANTES OF THE IN-DEPTH INTERVIEW}

Interviews (34 people, from 18 different organizations)

\begin{tabular}{|c|c|}
\hline \multicolumn{2}{|c|}{ Ministries and Presidency of Republic of Brazil } \\
\hline $\begin{array}{l}\text { Jose Accarini, Assistant deputy chief for } \\
\text { analysis and following up of government } \\
\text { policies; substitute of the biodiesel federal } \\
\text { program coordinator }\end{array}$ & $\begin{array}{l}\text { Presidency of Republic of Brazil, } \\
\text { Office of the chief of staff for the } \\
\text { presidency }\end{array}$ \\
\hline $\begin{array}{l}\text { Director of the department of renewable fuels: } \\
\text { Ricardo de Gusmão Dornelles }\end{array}$ & \multirow[b]{2}{*}{ Ministry of Mines and Energy } \\
\hline $\begin{array}{l}\text { General coordination of biofuel planning } \\
\text { coordination of energy information: João } \\
\text { Antônio Moreira Patusco. }\end{array}$ & \\
\hline $\begin{array}{l}\text { Marcio Hirata from Bureau of Land } \\
\text { Regularization in the Amazon/ Director of } \\
\text { Planning, Monitoring and Evaluation } \\
\text { Secretariat substitute }\end{array}$ & \multirow[t]{2}{*}{ Ministry of Agrarian Development } \\
\hline $\begin{array}{ccc}\text { Marco } & \text { Pavarino, } & \text { from } \\
\text { CGBIO/DEGRAV/SAF/MDA } & , \\
\text { Coordenação-Geral de Biocombustíveis- }\end{array}$ & \\
\hline $\begin{array}{l}\text { João da Silva Abreu Neto, General } \\
\text { coordinator of agroenergy }\end{array}$ & $\begin{array}{l}\text { Ministry of Agriculture, Livestock and Food } \\
\text { Supply, Secretariat of Production and Agro- } \\
\text { energy }\end{array}$ \\
\hline $\begin{array}{l}\text { Rafael Menezes, Energy R\&D Coordinator, } \\
\text { General coordination for sector Technologies }\end{array}$ & \multirow{2}{*}{$\begin{array}{l}\text { Ministry of Science, Technology and } \\
\text { Innovation. Secretariat of Technological } \\
\text { development and innovation }\end{array}$} \\
\hline $\begin{array}{l}\begin{array}{l}\text { Gustavo de Lima } \\
\text { coordinator for actions, } \\
\text { development }\end{array}\end{array}$ & \\
\hline $\begin{array}{l}\text { Luciano Cunha de Sousa, Foreign trade } \\
\text { coordinator. }\end{array}$ & $\begin{array}{l}\text { Ministry of development, industry and foreign } \\
\text { trade }\end{array}$ \\
\hline \multicolumn{2}{|c|}{ Nacional agency } \\
\hline $\begin{array}{llll}\text { Rosângela } & \text { Moreira de } & \text { Araújo, } \\
\text { Superintendent } \\
\text { Quality }\end{array}$ & \multirow{5}{*}{$\begin{array}{l}\text { ANP - National agency for petroleum natural } \\
\text { gas and biofuels, Superintendence of } \\
\text { biofuels and product quality }\end{array}$} \\
\hline Fernanda Vieira Pinto & \\
\hline Marcela Flores & \\
\hline Jackson Albuquerque & \\
\hline Cristiane & \\
\hline \multicolumn{2}{|c|}{ Brazil Energy Research Company } \\
\hline Pedro Ninô de Carvalho & $\begin{array}{l}\text { Brazil Energy Research Company EPE } \\
\text { (linked to Ministry of Mines and Energy), } \\
\text { Team responsible for Bioenergy Research }\end{array}$ \\
\hline Euler João Geraldo da Silva & \\
\hline$B r$ & arch Corpor \\
\hline
\end{tabular}




\begin{tabular}{|c|c|}
\hline Manoel Teixeira Souza Jr. Director-general & $\begin{array}{l}\text { EMBRAPA: Brazilian Agricultural Research } \\
\text { Corporation - Agroenergy }\end{array}$ \\
\hline \multicolumn{2}{|c|}{ Producers } \\
\hline $\begin{array}{l}\text { Julio Cesar Minelli - Superintendent Director } \\
\text { Antonio Ventilii - Assessor técnico }\end{array}$ & $\begin{array}{l}\text { APROBIO- Brazilian association of biodiesel } \\
\text { producers }\end{array}$ \\
\hline $\begin{array}{l}\text { Odacir Klein - former Ubrabio President } \\
\text { Professor Doctor Donato Aranda, Assessor } \\
\text { (also professor at Federal University of Rio } \\
\text { de Janeiro) }\end{array}$ & $\begin{array}{l}\text { UBRABIO Brazilian association of } \\
\text { biodiesel }\end{array}$ \\
\hline \multicolumn{2}{|c|}{ Workers representative } \\
\hline Antoninho Rovaris - Environment Secretary & $\begin{array}{l}\text { National Confederation of Agriculture } \\
\text { Workers }\end{array}$ \\
\hline \multicolumn{2}{|c|}{ Congressmen } \\
\hline Deputy Evandro Gussi & President of Parliamentary Front Biodiesel \\
\hline Gilney Vianna & $\begin{array}{l}\text { Former deputy, pioneer in the discussion of } \\
\text { biodiesel in the Chamber of Deputies }\end{array}$ \\
\hline \multicolumn{2}{|c|}{ Professors, researches } \\
\hline Ronaldo Perez & University of Viscosa \\
\hline Donato Aranha & University of Rio de Janeiro \\
\hline Ole John Nielsen & University of Copenhagen \\
\hline Gerd Sparoveck & University of São Paulo/ESALQ \\
\hline \multicolumn{2}{|c|}{ Dealers } \\
\hline Ricardo R A X Menezes, vice president & $\begin{array}{l}\text { Union of Brazilian regional distributors of } \\
\text { fuels }\end{array}$ \\
\hline Sandro Paes & Petrobrás \\
\hline \multicolumn{2}{|c|}{ Minor producers } \\
\hline Adilson Liebsch, former management & AMYRIS \\
\hline Celia Marcondes Smith & Ecoleo \\
\hline $\begin{array}{l}\text { Scott Vaughan, President and Chief } \\
\text { Executive Officer }\end{array}$ & IISD- International Institute for Sustainable \\
\hline
\end{tabular}




\begin{tabular}{|l|c|}
\hline & Development \\
\hline $\begin{array}{l}\text { Miguel Angelo Simczak Vedana, Executive } \\
\text { diretor }\end{array}$ & BiodieselBr (Magazine) \\
\hline
\end{tabular}




\subsection{INTEGRATING DRIVING FORCES INTO STORYLINES - THE CASE OF SCENARIOS FOR THE BIODIESEL INDUSTRY IN BRAZIL, BY 2030.}

\section{Abstract}

The objective of this work was to develop the scenarios storylines for the biodiesel industry in Brazil, by 2030, following the Intuitive Logic School. The critical uncertainties were chosen in previous work with sustainable dimensions as a framework. The peculiarities of developing these storylines were twofold. First, the following three aspects from one of the critical uncertainties: the commitment of the Brazilian government to fulfilling international agreements; the deforestation of the Amazon region and MAPITOBA states and its impacts; the land occupation, land titling (in amazon region) and the restoration of degraded land. Second, as scientific work, the assumptions for 2030 must have a consistent basis. The methodology utilized was to identify the current status and the recent facts that could be relevant to polarize the uncertainty, in order to generate two alternatives for the future. This illuminated the different directions (assumptions) for the uncertainties brought about by different decisions or events. Based on the combination of the polarized directions of the critical uncertainties, the scenarios storylines were developed. Then, they were submitted to the people who generated the uncertainties, in order to be validated in a Delphi survey, in terms of coherence, plausibility and timeline. The final results showed that it is easier to believe in positive scenarios than in the catastrophic one. In this case, it is easier to believe in technological advances than in the effects of climate change.

Keywords: biodiesel Brazil, scenario storylines, critical uncertainties, climate change 


\subsubsection{Introduction}

The aim of the work is to develop the scenarios storylines for the biodiesel industry in Brazil, by 2030, from an especial set of critical uncertainties, which were chosen in a previous work - section 3.2 and (Dias \& Vianna, 2015). There is a peculiarity in the first critical uncertainty because it is composed by three aspects: the commitment of the Brazilian government to fulfilling international agreements; the deforestation of the Amazon region and MAPITOBA states and its impacts; the land occupation, land titling (in amazon region) and the restoration of degraded land. The second uncertainty was the technological advances.

Biodiesel is produced all over Brazil. It is strongly regulated by PNPB - National Program for the Production and Use Biodiesel, and it is quite a new market at the industrial scale, since the most important producers in the world, including Brazil, began producing the biofuel 10 years ago approximately. As a source of energy and derivate from agriculture production, biodiesel has been the subject of controversial discussion on the basis of environmental benefits, competition with mineral diesel, deforestation, competition with food for land, etc. In Brazil, there are many stakeholders in this market, such as, producers, workers, dealers, several governments' institutions, researchers, political representatives, non-governmental companies, and so on. Therefore, developing scenarios for the biodiesel industry in Brazil requires techniques that must be adapted to these characteristics.

Prospective energy scenarios, for national and international approaches, have been built with different steps. Even when choosing a particular method like Intuitive Logics or $\mathrm{GBN}^{22}$ matrix (Bradfield et al., 2005), the steps and tools vary. WEC, World Energy Council developed both the Global Energy Scenarios and the New Zealand Energy Scenarios using quantitative analysis, interviews, and workshops with experts (WEC, 2013, 2015a). National Grid developed UK Energy Scenarios with workshops, questionnaires and quantitative projections for each storyline (Nationalgrid, 2015). The Millennium Project, from the United Nations, published the Global Energy Scenarios (Millennium-project, 2006) that had been developed by specialists and was submitted to the general public via a Delphi survey in order to be validated (Gordon, 2007). In the Brazilian context, other methods were used to build scenarios for biodiesel. Sousa developed prospective scenarios for biodiesel, following the Grumbach method (Marcial \& Grumbach, 2008; Sousa, 2013): sending questionnaires to stakeholders, which were then inputted into a software to compute probabilities. The software chose the more likely scenarios. Vaccaro et al. worked on scenarios for the biodiesel in the State of Rio Grande do $\mathrm{Sul}^{23}$, using a tool called Systems Thinking and

\footnotetext{
${ }^{22}$ GBN means Global Business Network, a former company led by Peter Schwartz, in California (Bradfield et al., 2005).

${ }^{23}$ The second largest biodiesel producer state in Brazil.
} 
Scenario Planning. It took 15 meetings with specialists to develop the storylines (Vaccaro et al., 2010). Consequently, there is neither a simple nor a unique way to approach this work. However, none of those past efforts described the process of creating the scenarios storylines, which is likely due to the fact that they were a collective creation and did not follow a pre-defined process.

The initial information to build the scenarios for the biodiesel industry in Brazil was obtained by a simulation with a linear programming model in section 3.1 and (Dias, Bentsen, et al., 2015) and also by an in-depth interview with the stakeholders in section 3.2 and (Dias \& Vianna, 2015). These two phases resulted in the choices for the driving forces and the critical uncertainties. Subsequently, the challenge was to transform the critical uncertainties into scenarios storylines, in the absence of a workshop with all stakeholders in attendance. A storyline is the narrative of the scenario. It is based on the critical uncertainties, but it requires other elements to make the narrative consistent. There is no systematic and structured definition of a technique to elaborate the scenarios storylines from the critical uncertainties, especially when one of them is formed by three others.

The first contribution of this work is to address the gap of building a technique for developing scenarios, suggesting a rationale of creating the storylines, with practical and consistent steps. The second is the complete scenarios storylines. The methodology used was to analyse of each component of the critical uncertainty, looking for status and facts that could lead the uncertainty to assume different values. Afterwards, stakeholders in a Delphi survey evaluated their coherency and plausibility.

\subsubsection{Literature review}

The methods of developing the images (storylines) of the scenarios can be classified into eight groups (Bishop et al., 2007): Judgment, Baseline, Elaboration of fixed scenarios, Event sequences, Backcasting, Dimensions of uncertainty, Cross-impact analysis, and Systems modelling. The "Dimensions of uncertainty" group includes the Intuitive Logic of GBN matrix, and morphological analysis from La prospective school ${ }^{24}$ (Bishop et al., 2007). The Intuitive Logic method was chosen for this work due to two reasons. First, it uses the uncertainties as framework of the scenarios storylines, thereby allowing for easy inclusion of the sustainability dimensions - section 3.2 and (Dias \& Vianna, 2015) in the method. Second, because most energy scenarios found in the literature where developed using this

\footnotetext{
${ }^{24}$ A French set of methods to build scenarios. One of the most prominent researcher is Michel Godet (Bradfield et al., 2005).
} 
method, like the Global Energy Scenarios (Millennium-project, 2006) and others already mentioned in the item 3.3.1.

\subsubsection{Procedures to build scenarios in the Intuitive Logic method}

The steps followed for the development of the scenarios storylines are summarily listed as follows for the Intuitive Logic school: a) choose the subject, b) identify the uncertainties and choose the two most important and most uncertain, c) create $2 \times 2$ matrix, and finally, d) develop the storylines that are usually in workshops with specialists (Bradfield et al., 2005; GBN, 2012). The matrix is based on the polarization of the uncertainties (Bishop et al., 2007). The complete story of the each scenario is elaborated, using the matrix as foundation or framework (GBN, 2012).

Börjeson et al. (2006) define three generic steps for developing scenarios: generating ideas and gathering data; integration of the information obtained; and checking the consistency of scenarios (Börjeson et al., 2006). In the Intuitive Logic method, the integration of the information is done when the $2 \times 2$ matrix is create and the scenarios storylines are elaborated. Establishing the scenario set means defining the scenario logics as organizing themes or principles (Bradfield et al., 2005). Usually this phase is done in workshops with experts; however, there is no systematic technique for this task.

\subsubsection{Criteria to validation the scenarios}

After creating the storylines, it is important to check for their validity in order to ensure that they form an adequate basis for making decisions (Chermack, Lynham, \& Ruona, 2001).

The usual criteria for validation of the scenarios are: plausibility, consistency/coherence, creativity/novelty, relevance/pertinence, importance, transparency, and completeness/correctness (Amer et al., 2013). However, the two most used criteria are plausibility and coherence (Amer et al., 2013), which are defined by as follows (Wilson, 1998):

a) Plausibility: they have to be capable of happening,

b) Coherence/consistency: the combination of logics in a scenario has to ensure that there is no built-in internal inconsistency and contradiction.

In order to validate the scenario storylines, a Delphi survey was performed.

\subsubsection{Delphi technique}

Delphi is described as a process of communication (Stitt-Gohdes \& Crews, 2004), aiming to achieve the convergence of opinions and consensus building about real issues (Helmer, 1967; Hsu \& Sandford, 2007), where there is uncertainty or lack of empirical 
evidence (Powel, 2003). The procedure generates anonymous debates and captures the collective intelligence. Even when there is no consensus, or no condition to continue with the rounds until consensus is achieved, Delphi serves to crystallize different positions on the issue, showing different interpretations of the same data or revealing different schools of thought (Helmer, 1967).

The participants of a Delphi survey are called panellists. The key features in the Delphi method are the panel size and qualifications of the panellists. Their success relies on selecting the right people, in terms of representatively, i.e. on the qualities of the experts and not on the quantity (Turoff, 1975).

Delphi can be used in combination with several other techniques such as cross-impact matrix (Bañuls \& Turoff, 2011; Helmer, 1967), hierarchical panel (Helmer, 1967; Pincombe, Blunden, Pincombe, \& Dexter, 2013) or quantitative analysis (Hanafin, 2004; Landeta, 2006; Tapio, Paloniemi, Varho, \& Vinnari, 2011).

\subsubsection{Methodology}

\subsubsection{Background - where the critical uncertainty come from?}

To develop prospective scenarios for the biodiesel industry, four step were carried out: first, simulations with a linear programming model were completed in order to identify all the possibilities of producing biodiesel in Brazil - described in section 3.1. and in (Dias, Bentsen, et al., 2015) In a second step, a cross-disciplinary theoretical work was carried out to adapt the method to the sustainability Sachs 's approach; third, in-depth interviews were conducted with the main stakeholders of the industry regarding their perception about the possible future for the biodiesel industry. Fourth, as a result of three steps, the driving forces were chosen. The second, third and fourth are described in 3.2 and (Dias \& Vianna, 2015). These steps are shown in the Figure 21 , where there are also the further steps that will be described hereinafter.

The critical uncertainties are: 1) Level of response to climate change and environmental conservation and 2) Technological advances (gradual and breakthroughs). Three others compose the first one:
a) The commitment of the Brazilian Government to fulfilling international agreements
b) The deforestation of the Amazon region and MAPITOBA states and its impacts
c) The land occupation and land titling, and the restoration of degraded land. 


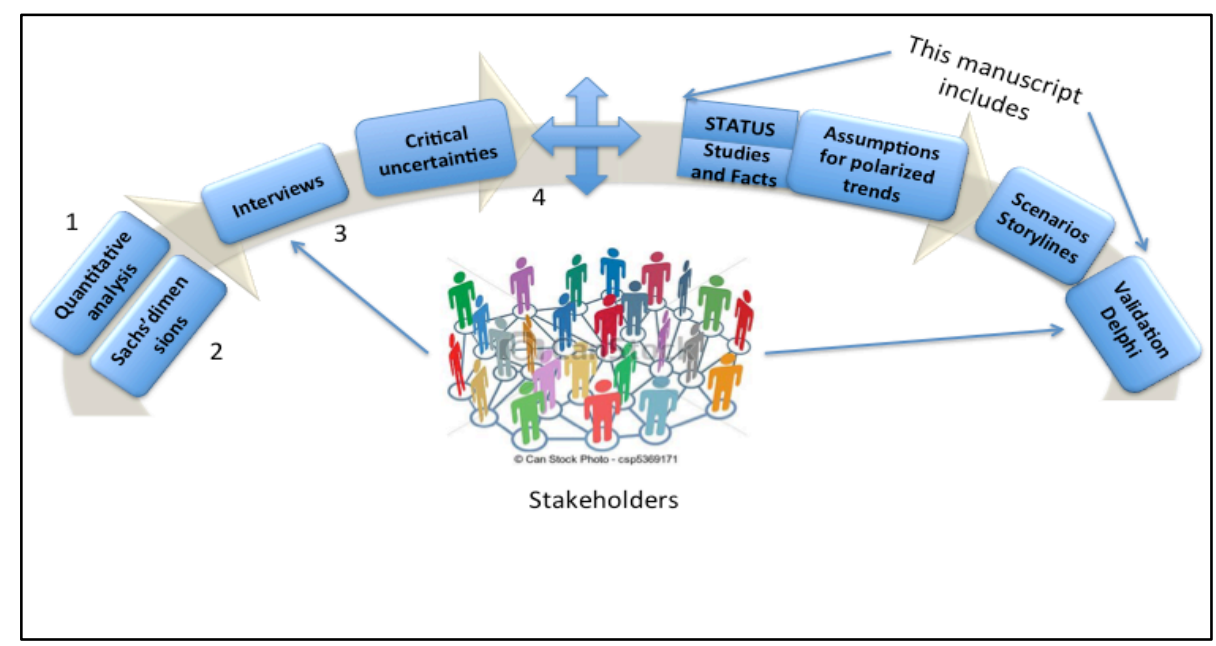

Source: elaborated by the author

Figure 21 - The complete scenarios method

The two critical uncertainties form the axes of the $2 \times 2$ matrix (or Cartesian coordinates) as it is shown on Figure 22. The signal "+" in vertical axis represents strong response to climate change and environment conservation. Combining all assumptions for this uncertainty a strong response for the three aspects would mean all measures to avoid deforestation, to restore degraded land, and to control the occupation of land in Amazon biome are taken. The signal "-" in vertical axis represents weak response to climate change and environment conservation. In this case, it was assumed that the measures needed were not taken or they did not have the expected result. Moreover, it was assumed that the expansion of the agriculture frontier in Brazil would continue through the deforestation in the Amazon biome and MAPITOBA ${ }^{25}$ states, in protected and non-protected land indiscriminately.

The extremes in the horizontal axis are gradual advances in biodiesel feedstock and production at one end and technological breakthrough in fuel and engines at the other. The speed of the adoption of the technological advances is assumed to be gradual. The exception is the quadrant four where the neglected effects of not protecting the environment bring economic problems, which do not allow investing in new fuel technologies.

\footnotetext{
${ }^{25}$ Acronyms for the states Maranhão, Piauí, Tocantins and Bahia
} 


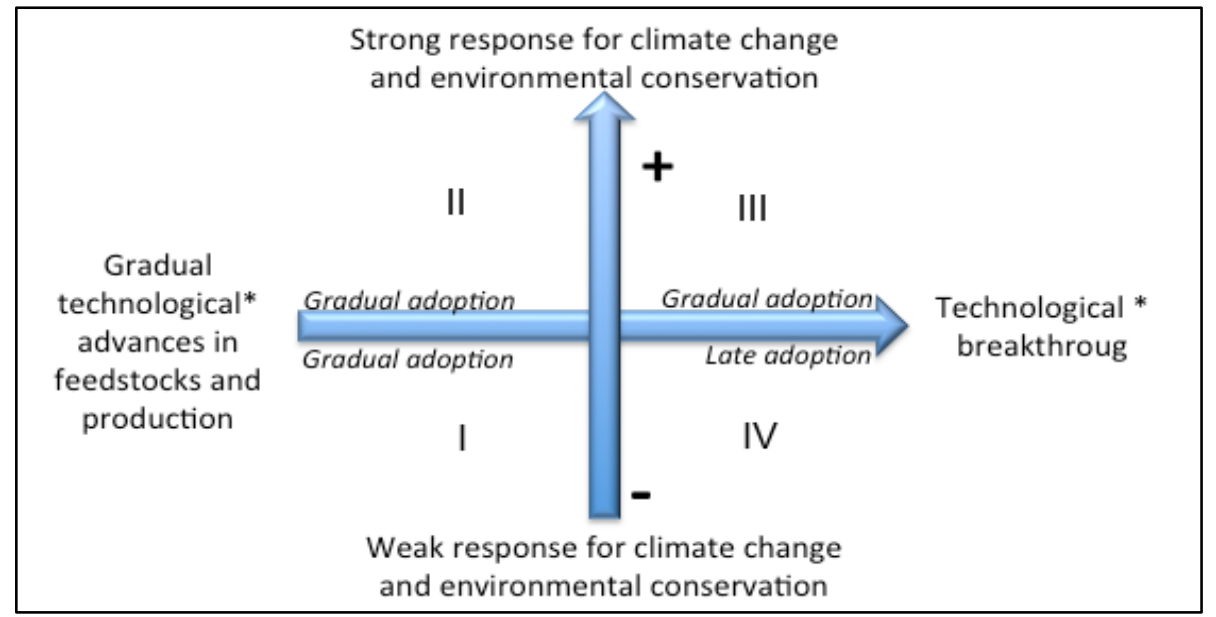

Source: (Dias \& Vianna, 2015)

Figure 22 - Framework for scenarios for biodiesel production, by 2030.

\subsubsection{Methods}

The following steps were taken in order to integrate the critical uncertainties into storylines; first, the current status of the two uncertainties was sought in academic works, reports published or consistent information from government sites and reports. As a second step, the possible facts indicated that changes were being undertaken, such facts were also documented in trustable source (academic works and newspapers). Notice that this "status" does not mean a complete bibliography review. It was based on the interviews. Finally, assumptions for the time horizon were made for each uncertainty in two polarized directions.

The combination of the assumptions in each quadrant of the Figure 22 was, therefore, the basis of each storyline. Some elements, identified in the interviews conducted, described in 3.2 and in (Dias \& Vianna, 2015) were added to the storylines in order to complete the scenes. Once the storylines were completed, the Delphi survey was elaborated to validate them. The Delphi was available in the URL: www.biodiesel2030.com.br from September 2015 to December 2015. The complete questionnaire and the answers of the first round can be seen in the Annex IV.

As elaborated in section 3.3.2.2 the most utilised criteria, namely, coherence and the plausibility (Amer et al., 2013) were examined in a Delphi survey. The Delphi questionnaire was pretested by 9 people (see in Annex $V$ the list of people in pre-test procedure), in English and Portuguese, as usually recommended (Turoff, 1975). The nine people were part of the target audience, others not.

\subsubsection{2.a Target audience}

The panellists were the same people invited to the interview to define the driving forces. Few panellists did not participate in the interview due to limitations of time and logistics. Of the 39 people previous chosen, 33 were interviewed from 23 organizations - 
section 3.2 and (Dias \& Vianna, 2015); and 21 completed the Delphi. The complete list of the panellists can be seen in the Annex VI.

\subsubsection{2.b Delphi}

The storylines scenarios were then updated according to the pre-test results. The panellists were invited to assess the scenario storylines in two rounds of Delphi. In order to evaluate the degree of coherence and plausibility, there were questions for each of the four scenario storylines, with the alternatives: high, medium and low. Also, the panellists were asked about the time more likely to happen the each storyline: by 2030 , before 2030 , after 2030, and never. Then, there were questions about the values of some indicators like the mandate, participation of feedstock, number of small families farmers included and so on.

After the first round, the answers were computed and the percentage of each alternative, for each question, was calculated. For the questions about the indicators, the average of the answers were computed.

For the second round, the previous answers for each panellist, and the group percentages and averages were shown. The panellists were asked to compare their answers to the group values and, if they want, they could change. They were also asked to comment the answers if they want to.

Almost nobody wanted to change his or her answers in the second round. Few panellists attributed values to the indicators. Therefore, these results of the indicators were not considered here, but only the ones regarding coherence, plausibility and the most likely time to occur the scenarios.

\subsubsection{Results and analysis}

3.3.4.1 Critical uncertainty level of response (of Brazilian government) to climate change and environment conservation

As it was already mention in item 3.3.3.1, three aspects closely related compose this critical uncertainty. It will drive how is going to be the expansion of the agriculture frontier, which is essential for the future of biodiesel feedstock. They are detailed hereinafter.

\subsubsection{1.a Climate change International agreements}

a) Status

The target of limiting global warming to $2^{\circ} \mathrm{C}$ was in the Copenhagen Accord at COP 15 in 2009 (UNFCC, 2010). Between 2009 and 2014 the global economy has missed the decarbonisation target needed to meet the accord (UNEP, 2015). The Global Carbon Intensity fell $0.9 \%(2000-2013)$ and $1.2 \%(2014)$. In order to meet the global target of limiting 
at $2^{\circ} \mathrm{C}$ warming, it would be necessary to be $6.2 \%$. Thus, it is still necessary a huge effort. The E7 group (China, India, Brazil, Mexico, Russia, Indonesia, and Turkey) appears to have woken up to the business logic of green growth, decarbonising their economies faster than the $\mathrm{G} 7$ countries, for the first time recorded. Anyway, growth of renewables across both the G7 and E7 is occurring (REN21, 2014). Lately, the commitment signed by 195 countries in COP21 is likely to keep the warming at $2^{\circ} \mathrm{C}$ (UN, 2015), by 2100 .

By one hand, Brazil is in a very comfortable situation regarding GHG emissions. From 1990 to 2013 Brazil experienced a reduction in GHG emissions of 24\% (SEEG/OC, 2015) primarily driven by a decrease of deforestation. Moreover, the share of renewables in the Brazilian energy supply was $39 \%$ in 2014 (Brazil, 2015a; OECD/IEA, 2015). Indeed, the Brazilian's commitment presented to COP21 mentioned that:

Brazil's current actions in the global effort against climate change represent one of the largest undertakings by any single country to date, having reduced its emissions by $41 \%$ (GWP-100; IPCC SAR) in 2012 in relation to 2005 levels (Brazil, 2015b).

On the other hand, the emissions have increased since 2010 in all sectors but land use (SEEG/OC, 2015), and the share of renewables in the Brazilian energy supply was $50 \%$ in 1990 dropping to $39 \%$ in 2014 (Brazil, 2015a).

b) Assumptions for weak response

The two facts: the decrease in the deforestation rate and having still a considerable percentage of renewables in the energy supply can lead to Brazil do not establish ambitious targets on GHG emission reductions until 2030, and no extra funding is allocated for reforestation nor for increasing the share of renewables in the energy matrix. Biodiesel would be still required, but it is more likely to maintain the mandate like it is today.

c) Assumptions for strong response

Now that, apparently, the deforestation is controlled, the energy sector would be the next target to decrease the emissions. Especially because this sector has had the greatest increase in GHG emissions and the percentage of renewables dropped $11 \%$ in the last 24 years. These situation of the energy sector and the general optimism about COP21 in Paris in 2015 due to the declarations of US president Barack Obama and China's president XI Jinping announcing ambitious target to reduce emissions (Ninio, 2015), can lead Brazil to agree to reduce emission in the energy sector (that includes the transport sector). Increasing wind and solar energy capacity, and the biofuels production would be the answer. It would motivate to increase the biodiesel mandate that is currently $7 \%$. 


\subsubsection{1.b Deforestation of Amazon region and MAPITOBA states and its impacts}

a) Status

Extreme weather events all over the world (IPCC, 2014) have caused harvest losses and have brought extra pressure to produce food, especially in Brazil (IEA, 2011). The rainy season is now shorter, although the volume of water is the same. It results in higher frequency of heavy precipitation events and longer dry season, especially in low latitudes, which agrees to scenario RCP6. $0^{26}$ (IPCC, 2014). The Amazon plays a critical role in regional and global climate stability, not just because it locks carbon into its soils and vegetation, but due to its role in promoting air and moisture circulation, from the Atlantic Ocean to the eastern Andean slope and to the central and southern parts of South America. This is called flying rivers of the Amazon Forest. It is a phenomenon that circulates water vapour and has a strong impact on the climatic conditions within the biome and around it (Nobre, 2015).

The rate of Amazon deforestation decreased from 27,772 (2005) $\mathrm{km}^{2} /$ year to 5,012 $\mathrm{km}^{2} /$ year in 2014 (INPE, 2015), but the total deforested area was $700.000 \mathrm{~km}^{2}$ up to 2014 (INPE, 2015). Even though the rate of deforestation is stabilized, over the last 3 years (INPE, 2015), it has not stopped yet. National and International organizations related to Climate Change, as well as developed countries are demanding for the end of the deforestation (Brasil247, 2015; EBC, 2015a; Globo, 2015). One of the deforestation drivers, the illegal logging (Hosonuma et al., 2012) in Amazon has not yet been extinct. Indeed, further reductions in Amazon rainforest deforestation are likely to require a shift towards policies that be area tailored and to different actors (Godar, 2014). But constraints such as limited financial and human resources, limited integration or coordination of governance; uncertainties about projected impacts; different perceptions of risks are obstacles to implement mitigation measures (IPCC, 2014).

The region's abundance of natural resources is currently being exploited on an industrial scale. The economic development in the Amazon region varies greatly among the countries of the region. It is estimated that the Amazon regional GDP reaches US $\$ 330$ billion dollars per year, of which the Brazil portion alone accounts for more than $70 \%$. The annual average GDP per capita for the region is US\$5,500 thousand dollars, but there is great variation between the countries (Maretti et al., 2014). In Brazil, the HDI of the Amazon region was 0,6 in 2014 (IBGE, 2015a), one of the lowest ones in the country.

\footnotetext{
${ }^{26}$ The global mean surface temperature change for the period 2016-2035 relative to 1986-2005 is similar for the four RCPs and will likely be in the range $0.3^{\circ} \mathrm{C}$ to $0.7^{\circ} \mathrm{C}$ (medium confidence). IPCC,2014, page 10
} 
b) Assumptions for strong response

A strong response would be Brazil stopping deforestation in the Amazon region, and accomplishing the Forest code all over the country, due to the commercial relationship with developed countries and the international agreements. It would mean restoring 44 Mha of degraded former forest land (Brazil, 2012a; WORLDBANK, 2011). These facts would be an obstacle to the expansion of the agriculture frontier. Thus, one solution would be adopt semiintensive pasture, which would free up almost 100 Mha of land to agriculture until 2030. The average yield of pasture in Brazil is low - 1 head by ha (IBGE, 2015b). This number varies a lot and there is not accurate information about how much degraded pastureland there are in Brazil. There are intensive and extensive systems of pasture. It is expected that pasture yield rate will rise to $1.34 \mathrm{head} / \mathrm{ha}$, by 2050 (Brazil/MME/EPE, 2014), would free up more land to agriculture. But incentives and financial compensations are needed.

Besides that, the remaining areas that are not protected - 114 Mha - (Sparovek et al., 2015) would be occupied by an integration crop-livestock-forest (agriculture, pasture and forest); more sustainable extractive activities would be promoted, respecting the traditional and indigenous activities in Amazon. Thus, the scenarios of sustainable development and regional development and quality of life, developed in 2001 for the Amazon region (Porto, 2001) would come true. In this context, Biodiesel feedstock would come from marginal and restored degraded land.

c) Assumptions for weak response

A weak response would be do not establish any other ambitious targets related to deforestation rate. External pressure to reduce $\mathrm{CO}_{2}$ emissions in the Amazon forest is not stronger as the pressure for producing food. The strong pressure from agriculture sector would lead to the occupation of all land that is not protected, converting native vegetation in Amazon and nearby. Big companies have more commercial power to pressure to occupy the land that is not protected. The difficulty of maintaining surveillance on a so large area facilitates the continuation of illegal logging, which, by the way, has always new strategies to circumvent the surveillance. It this context, the scenarios of the agriculture growing and environmental degradation, or stagnation and poverty (Porto, 2001), would come true. Biodiesel feedstock would be easier obtained from soybean and beef tallow, the same way it is nowadays. 


\subsubsection{1.c Land occupation and restoration of degraded land}

a) Status

Clearer property rights would improve the sustainable use of land and would avoid encroaching on the Amazon rainforest (OECD-FAO, 2015). The "Terra Legal" program is helping to legalize and to control land tenure (regarding small holders). By March 2015, 10\% (1.4 Mha) of the total expected land were titled. (Brazil/MDA, 2015). The program also requires the compliance with the Forest Code. But more than that is necessary to solve the land tenure and stop the deforestation, because only $12 \%$ of deforestation of the Amazon rainforest between 2004-2011 occurred in areas settled by smallholders, in contrast to $48 \%$ in areas of larger properties (> 500 ha) (Godar, 2014). Indeed very mechanized and technological crops, i.e. large companies, have occupied the Brazilian agricultural frontier in Amazon and MAPITOBA regions (Frederico, 2012).

It will be necessary to restore $44 \mathrm{Mha}$ in order to comply with the Forest Code all over the country (WORLDBANK, 2011). In accordance with PNMC's (Brazilian Climate Change Policy), ABC Plan (Low Carbon Agriculture plan) reinforced the Brazilian goals established at COP15. The $A B C$ Plan goals are to encourage the adoption of Sustainable Production System to ensure the reduction of GHG emissions and simultaneously raise the income of farmers, particularly with the expansion of the following technologies; the restoration of degraded pastures; the integration of crop-livestock-forest (iLPF) and Agroforestry Systems (AFS); the adoption of tillage practices (SPD); the application of Biological Nitrogen Fixation (BNF); and Planted Forest (Brazil/MAPA, 2012). The horizon is to accomplish ABC Plan within 20 years (from 2012 stating state) (Brazil/MAPA, 2012). In the individual level, the farmers in Brazil were also required to accomplish their PRA (Environmental Compliance Plan), in order to fulfil the Forest Code (OECD-FAO, 2015).

Economic situation has not been good, since Brazil has experienced several years in a row without relevant economic growth (GDP): 2012: 1.8\%; 2013: 2.7\%; 2014: $0.1 ; 2015$ : expect to shrink by 3.5\% in 2015 (IBGE, 2015a; WORLDBANK, 2015). The HDI in Amazon region and MAPITOBA states had the most significant increase from 2001 to 2010, but they are still amongst the lowest in Brazil (IBGE, 2015a). This situation can led to Federal Government to review the forest code lowing down the requirements and open more space to legally increase the deforestation in Amazon region and MAPITOBA states.

Indeed, the projections made by the Agriculture Ministry are that 69.4 Mha of arable land will be reached by 2024 (Brazil, 2014b; OECD-FAO, 2015). In 2014, the planted was already 58 Mha (CONAB, 2015b). It is likely that most of the increase will be from 
conversion of the natural vegetation to crops in MAPITOBA states (OECD-FAO, 2015) and the North Amazon (WORLDBANK, 2011), the poorest regions that have available land.

The number of small farmers included in biodiesel production is decreasing from 104,295 in 2011 to 44,304 in October 2014 (Brazil/MDA, 2015), showing that the social inclusion is becoming worse. And most of them are from centre-west and south region. Therefore, if the expansion of agriculture frontier will be in the Amazon an MAPITOBA states, there is no likely the number of small farmers in the Biodiesel National Program (PNPB) would increase.

b) Assumptions for strong response

In order to avoid further deforestation caused by an expansion of the agricultural frontier, there would be incentives and funding for recovering degraded land and pasture, to intensify pasture and transform land from pasture into agriculture. Brazil can make negotiations based on COP21 agreements in order to get support for such efforts since global actors support halting Amazon deforestation, and also because Brazil has a good record of accomplishment of curbing deforestation rates thus far. The PNDRSS ${ }^{27}$ objectives related to small farmers (CONDRAF-National-council-of-sustainable-rural-development, 2014) can be pursued as a sequential action to the Terra Legal program. The scale of the small/medium farms is more suited to the niches of agro-ecology, organic products and local demand. Therefore, the land titled in amazon for small and medium farmers would not use to produce biodiesel feedstock, what would lead to seek for degraded and marginal land in other regions of the country.

The diversification of feedstock for biodiesel is possible with oilseeds (sunflower, cotton, soybean, palm oil, macaúba, radish, peanuts, etc.), animal fats (beef, pork and chicken). Furthermore, diversification is also possible on a regional basis, which would allow the promotion the regional development, described in 3.1 and in (Dias, Bentsen, et al., 2015). However, it is expected China will continue to decrease soybean oil and soybean meal imports and increase the soybean grains imports, by 2024 (OECD-FAO, 2015). This would, eventually, decrease the soybean oil available and motivated the diversification of the feedstock used to produce biodiesel. However, if there are no plans to diversify biodiesel feedstock, there may be competition between the export of soybeans and biodiesel production.

\footnotetext{
${ }^{27}$ PNDRSS is the National Plan of sustainable, solidarity and rural development, approved by CONDRAF - national council of sustainable rural development.
} 
c) Assumptions for weak response

Farmers may receive extra time (to accomplish $\mathrm{PRA}^{28}$ ) due to bad economic conditions. They may claim that Brazilian government has not improved the logistic infrastructure, as it was necessary for decreasing the final agriculture costs. Indeed, due to the poor economic situation in Brazil in addition to a somewhat stagnated of Chinese economy, politicians would claim that changes are needed to the Brazilian Environmental Protection System (SNUC) in order to provide opportunities for economic activities. It seems that Amazon will always be the last frontier for economic development. (IMAZON, 2015)

As a consequence, the Amazon becomes one of the most disputed areas of land in the country. Nevertheless, government authorities will continue to work on land titling in the "Terra Legal” program, there would are still a lot of land disputes, which would bring political and social instability to the agriculture frontier and obstacles to the small farmers and traditional communities in the North and MAPITOBA states. There will be a low possibility that the total area be titled as part of the "Terra Legal" program in the next 15 years. This would be problematic for the sustainable occupation in Amazon region. It seems that big companies will be more present on the Amazon rainforest occupation, which mean that soybean and beef tallow will continue to be the main feedstock for biodiesel.

\subsubsection{Critical uncertainty: technological advances}

This uncertainty was built in a simpler way. The assumptions were made directly regarding the speed of the adoption process, which can be gradual or with delays.

\subsubsection{2.a Gradual advances in biodiesel production and feedstock}

a) Status

Technologies to produce biodiesel from microalgae, sugar-based hydrocarbons, biomass to liquids and hydro-treated vegetable oil (IEA, 2011) are available in 2015, but not on an industrial scale. Such Technologies include:

I. Biomass-to-liquids (BtL) diesel, also referred to as Fischer-Tropsch diesel, produced by a two-step process in which biomass is converted to a syngas rich in hydrogen and carbon monoxide. After cleaning, the syngas is catalytically converted through Fischer-Tropsch (FT) synthesis into a broad range of hydrocarbon liquids, including synthetic diesel and bio-kerosene.

II. Hydro-treated vegetable oil (HVO) is produced from hydrogenating vegetable oils or animal fats. The first large-scale plants have been opened in Finland and Singapore,

\footnotetext{
${ }^{28}$ PRA : recuperation plan for compliance with the Forest Code
} 
but the process has not yet been fully commercialized (Bacovsky, Dallos, \& Wörgetter, 2010).

III. Advanced biodiesel is not widely available at present, but could become fully commercialized in the near future, since a number of producers have pilot and demonstration projects underway (USDOE-US-Department-of-Energy), 2009).

b) Assumptions for gradual adoption

Brazil has made good progress in biofuels lately, and it is expected that it continue to do so. Advanced biofuels do not lead to a significant change in the engines, rather slight. Just adaptations. A gradual adoption might be interesting because there is time for planning such a change. The main reason to go in this direction is the pressure for food, expensive land, restrictions on expansion of agriculture and no restoration of degraded land. In any case, investments and/or public policies will be necessary to accelerate the adoption of innovation.

c) Assumptions for late adoption

It is expected that soybean will occupy 40 Mha by 2024 . Soybean, cotton, palm oil, and animal fat together would meet the internal demand of biodiesel, by 2030, with 14 billion litters or even more (Dias, Bentsen, et al., 2015). The abundance of vegetable oils and animal fat can delay the research and adoption of new technologies. A lack of investment is also an obstacle to the adoption of new technologies.

\subsubsection{2.b Technological breakthrough in fuel and engines}

a) Status

Hydrogen is an energy carrier that can be used to store, move and deliver energy produced from other sources (USDOE, 2014). It can be produced by thermal process that involves steam reforming. In a high-temperature process, steam reacts with a hydrocarbon fuel to produce hydrogen. Electrolytic and photolytic processes also can produce it. Hydrogen can be produced using diverse resources like fossil fuels, natural gas and coal (with carbon sequestration); nuclear energy, biomass, wind, solar, geothermal and hydroelectric power. Today, about $95 \%$ of all hydrogen is produced from steam reforming of natural gas (USA/EERE, 2015). Using fuel cells and hydrogen would represent a big change in engines and the way that the power is generated. It also could change the entire the transport system in the world. 
There is already a hydrogen buses project in São Paulo, since June 2015, which was carried on by a public-private consortium involving the Ministry of Mines and Energy (MME), Metropolitan Transport Company of São Paulo (EMTUSP), United Nations program for development (PNUD), Global Environmental Facility (GEF) and the Brazilian Financial Company for Projects and Research (FINEP)(Brazil, 2015e; EBC, 2015b; EMTU, 2015).

In case of this work, technology represents any technological advanced that can happen regarding automobile engines and/or power generation. So, if this or any other technological advance regarding the fuel and/or engines is available in commercial scale, it will be considered a technological breakthrough.

b) Assumptions for gradual or fast adoption:

Adopting this kind of technology requires investment and planning. However, it can begin if there is a strong reason like a large environmental disaster, or if there is a huge investment made. One condition that can favour these technologies is the fact that it doesn't depend on land to be produced. If the of climate change appear to be worse than anticipated, such as the extreme scarcity of land and water, or if problems in the oil supply, countries will look for alternatives to biofuels and fossil fuels. One alternative also could be the nuclear power, which is a variable not taken into account in this work. The Brazilian iNDC (Brazil, 2015b) for COP 21 agreements are opportunities to change the energy sector to more sustainable alternatives. The general assumption is that once it occurs in developed countries, there is a possibility of receiving foreign investments. This will then induce Brazilian energy to promote faster adoption to new technologies.

c) Assumptions for late adoption:

It is necessary to change the entire transport system, which is unlikely to occur in the 15 years horizon, especially considering the context of a developing country like Brazil. The main reasons are the abundance of land, even in Amazon, and the low average level of income of the population. As it has happened in the past, adopting of advanced technologies happens in just a few places, such as in the state of São Paulo, the richest one in Brazil.

\subsubsection{Building the storylines}

The assumptions shown in 3.3.4.1 and 3.3.4.2 regarding the uncertainties were combined in order to build a framework for the scenario storylines, as shown in Figure 22. Four scenarios were developed to correspond to the quadrants of the Figure 23 , as follows: 
BAU - Business as usual, SBS - Step by step, ABD - Abundance, and SCR - Scarcity, which are the combination of the critical uncertainties.

\subsubsection{3.a Business as Usual- BAU}

The BAU scenario is quadrant formed by a weak response to climate change and gradual adoption of technological advances in biodiesel and feedstock (Figure 23). It assumes that the dynamic of doing business in the biodiesel industry continue to be the same. Therefore, by 2030 the biodiesel production is still reliant on the use of vegetal oils and animal fat. Other feedstock and/or production technology will only occupy a small share of the market.

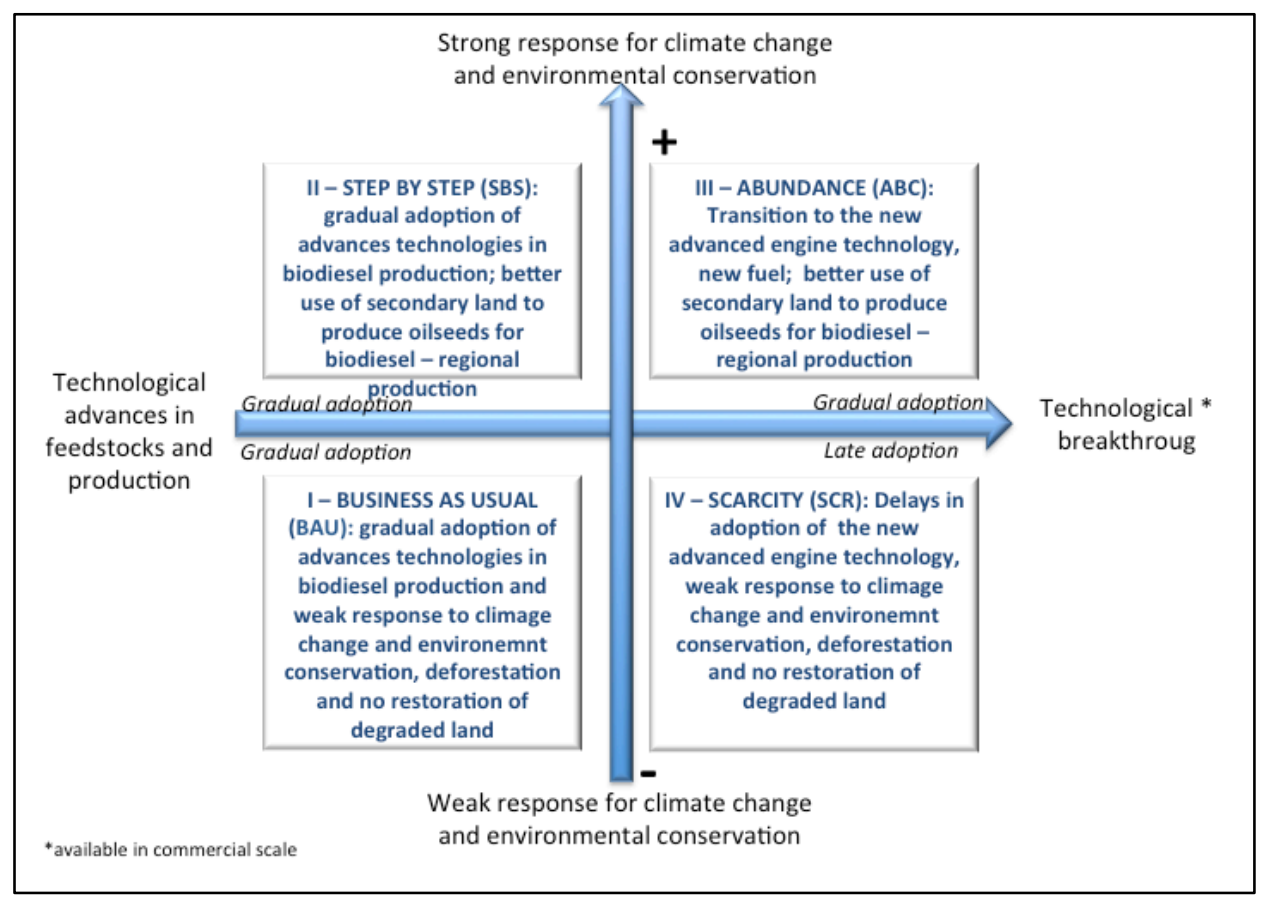

Source: elaborated by the author

Figure 23 - Scenario matrix for the biodiesel industry in Brazil, 2030

\section{$B A U$ description}

Brazil didn't recover its degraded land, as it would be expected in ABC Plan ${ }^{29}$ (Low Carbon Agriculture Plan). Despite the numerous reports alerting to the effects of deforestation such Amazon died back (transmutation to savannah or other biodiverse landscape) and all the direct consequences for the climate changes in the Brazilian Central region, the deforestation rate persists around $5000 \mathrm{~km}^{2} / \mathrm{year}$, or more. Some progress has

\footnotetext{
${ }^{29}$ This acronym comes from "Low Carbon agriculture" that in Portuguese is Agricultura de baixo carbono (Brazil, 2012b).
} 
been made regarding the production of soybean and other oilseeds more resistant to the dry season. Also, the efficiency of the biodiesel production process has been improved, but the most common feedstock continues to be soybean and beef tallow. Few other feedstock have minor participation on the biodiesel feedstock matrix. The Brazilian economic and political situation is not stable enough to provide predictability for producers of biodiesel regarding the blend percentage. In addition to this, the increasing Chinese demand for soybean grains results in strong and tense negotiations between government and soybean producers. The hope that biodiesel would be produced from palm oil did not materialize and most of it is used for food production and exports. The only alternative is to adopt the second generation of biodiesel or decrease the mandatory blend. The latter option will cause a lot of health damage, which society cannot accept. A transition situation from biodiesel produced by oilseeds to advanced biodiesel becomes the solution, even though it is a more expansive alternative. The blend in large cities is higher than in other areas, in order to avoid the cardiorespiratory diseases.

\subsubsection{3.b Step by step (SBS)}

This scenario depends on the gradual adoption of technological advances in biodiesel and feedstock, and strong response to climate change with focus on native vegetation protection. It can be seen in quadrant II, Figure 23. Recovering and using degraded land will make possible the inclusion of local oilseeds as biodiesel feedstock. This will change the industry dynamic promoting regional development and more social inclusion. The diversity of feedstock and land available will make easier the large-scale exports.

\section{SBS Description}

Degraded land in the Amazon is being restored mostly with palm oil. Other plants that had already been cultivated in Brazil, such as macaúba, babassú, coconut, and pequi were grown in the pasturelands alongside soybean. Thanks to the external funding, the forest code was complied with easier and now there are more options in terms of oilseeds to produce biodiesel. There are some local biodiesel production projects that are used to produce electricity for small communities, helping the local socioeconomic development. The biodiesel mandate could be increased thanks to the diversification of feedstock, improving energy and food security. Therefore, it was possible to meet to national demand for biofuel and the increasing world demand of food. However, due to the technology available for the production of second generation of biodiesel and incentives from public policies and support from international organizations, some pilot plants start to adopt them. The intent is to direct 
all vegetable production for human or animal consumption, because the population is still growing all over the world.

\subsubsection{3.c Abundance (ABC)}

In the third quadrant of Figure 23, technological breakthrough will be commercial available, like hydrogen and fuel cells. By 2030 developed countries will start to employ them. In Brazil, which will have recovered degraded land and protected the Amazon rainforest, the biodiesel production will be plenty. Nevertheless, developed countries will not import biodiesel. Brazil will have time and available funding to start innovation plans.

\section{$A B C$ description}

We are experiencing a transition situation from biodiesel produced by oilseeds to advanced biodiesel. Due to international agreements approved late in 2015; developing countries like Brazil could join and follow the technological advances. Brazil accomplished its ambitious targets regarding environment protection and GHG emissions, and finally, has some benefits and funding for the new renewable fuel adoption plan. Brazil has adopted the second generation of biodiesel quicker than it was expected, but the greatest part of biodiesel is still produced oilseeds and animal residues. However, as the part the degraded land was restored, more oilseeds like palm oil, macaúba, babassú, coconut, and pequi are used to produce biodiesel, besides the traditional feedstock (soybean, beef tallow, cotton and chicken fat). New uses for soybean oil were developed. It is expected that in 5 years, Brazilian urban transport system will start using hydrogen and fuel cells, pushing biodiesel for use mainly in freight transport between cities.

\subsubsection{3.d Scarcity (SCR)}

This scenario takes place in the fourth quadrant of the Figure 23 , where there will be a technological breakthrough like in $A B C$ scenario. However, delays in protecting the environment and recovering degraded land, added to water and climate stress will worsen the Brazil's socioeconomic conditions. This situation will not allow the adoption of new technologies and can lead to biodiesel scarcity. Notice that, even though this scenario is in the quadrant of fast adoption (right side of the uncertainty in Figure 23), there will not be resources for a comprehensive adoption due to scarcity result for the low environment protection. 


\section{SCR description}

Fuel cells and hydrogen are already available on a commercial scale. The second generation of biodiesel (called advanced biodiesel) no longer compete. Brazil did not accomplish its own targets to recover degraded land, as it was envisaged in the Low carbon agriculture plan (ABC Plan) (Brazil, 2012b) from 2012. In addition, the Forest Code and the Environmental Protection System (SNUC) were changed due to the bad economic situation from 2015 to 2017. What was foreseen in IPCC 2014 did occur. Climate change impacts worsened in the central region of Brazil due to the increasing rate of deforestation in Amazon and to non-restoration of other planned areas. In 2030 there are many problems associated with long dry season and extreme events. Amazon rainforest is really becoming a savannah (cerrado). China changed its soybean demand - is importing much more whole grains than soy meal. Other productive chains were not structure to produce biodiesel; therefore, there is a competition between producing biodiesel and exporting soybean grain. The opportunity to export biodiesel was also lost. First, because the EU countries demanded biofuel from second generation production methods, and then fuel cells and hydrogen became commercial viable. Brazil has few plants producing advanced biodiesel but the transportation infrastructure across the globe is being completely transformed.

\subsubsection{Scenario analysis}

Technology, will without a doubt, influence the biodiesel sector. However, the level of adoption varies in each scenario. The gradual adoption of technology was only for the upper quadrants, scenarios SBS and $A B C$ of Figure 23. The logic is that in both scenarios, environmental conservation helps to improve economic and social situation. These factors, in turn, help the innovation adoption (Rogers, 2003) and the speed of adoption is greater in the SBS and $A B C$ scenarios than in the BAU and SCR scenarios. Thus, the gradual adoption of innovations in biodiesel production and feedstock are in the SBS scenario and late adoption occurs in the BAU scenario. The innovation in fuel and engines are faster in $A B C$ scenario and slower in the SCR scenario.

Growth in the energy sector usually depends strictly on economic growth. However, in the set of scenarios included in this study, the economic growth was not chosen as an uncertainty. It may be explained by the stage of biodiesel industry, which has obtained a significant scale to be considered stable industry.

The health benefits also were not chosen as uncertainty, because they were already verified (Saúde-e-Sustentabilidade \& APROBIO, 2015) and they reinforce the biodiesel use. 
Such benefits will likely be the driving force that will not allow the biodiesel consumption decreases.

The price and availability of oil were not chosen as uncertainties that could strongly interfere in the future of biodiesel industry according to the results of the interview previously conducted in a past study (Dias \& Vianna, 2015). This is likely due to the gains from promoting a new sector, such as the biodiesel industry, as well as the environment and health benefits.

Care for the environment is a theme that drove the scenario storylines in a broad sense, in the biodiesel production process. The importance of this issue makes sense since the consequences of deforestation may affect the entire economy in the long run and may increase social vulnerabilities, especially in Brazil. Figure 18 (section 3.2) also captures this logic, especially for the case of Brazil. Diamond (2011) described experiences related to lack of environmental care and civilization decline in the Mayas, or isolated communities Eastern Island or, more recently, the comparison between Haiti and Dominican Republic (Diamond, 2011). Additional facts did contribute to their collapse; however, environmental care has been identified as an important one.

The four scenarios included in this study for the biodiesel industry reflect this situation. The two (SBS and $A B C$ ) in which the environment care is the main issue of progress, the obstacles are faced easier. When environmental factors are not as central, such as in the BAU and SCR scenarios, where deforestation is persistent, the biodiesel industry is made more vulnerable to external events.

Even though the territorial dimension represented by land occupation and land titling is one of the critical uncertainties, the social dimension inherent of these aspects did not appear very strongly in the scenarios.

The participation of the small family farmers is decreasing, year by year, from 104,295 in 2013 to 83,754 in 2013 (Brazil/MDA, 2015). To continue the social objectives of the program (Garcez \& Vianna, 2009), it is necessary to choose feedstock that requires labour force more than mechanization. The SBS and $A B C$ scenarios bring the possibility of regionalizing the production due to the restoration of degraded land. However, the choice of feedstock used to restore the land will determine the participation of small farmers or job generation. It is expected that in 15 years Brazil will still need to provide means of social inclusion for its rural population. Therefore, the biodiesel industry can still help this social dimension. 


\subsubsection{Scenario validation}

Ontologically speaking, the future is non-existent. Thus there is a fundamental reason why scenarios are not categorized as being true/false (Pillkahn \& Sasano, 2008). Therefore, the decisive conditions for assessing scenarios as credible, are plausibility and coherence /consistency (Amer et al., 2013).

Following the description in item 3.3.2.2, the scenarios storylines described in 3.3.4.3 were submitted to the panellists to assess coherence and plausibility for each scenario. The options for the responses for both criteria were high, medium, low and none at all. In addition, the panellists were asked when each scenario could happen: before 2030, in 2030, after 2030, or never. The results are shown in Table 18 for BAU, Table 19 for SBS, ABC, and Table 21 for SCR.

Table 18 - Results for scenario BAU

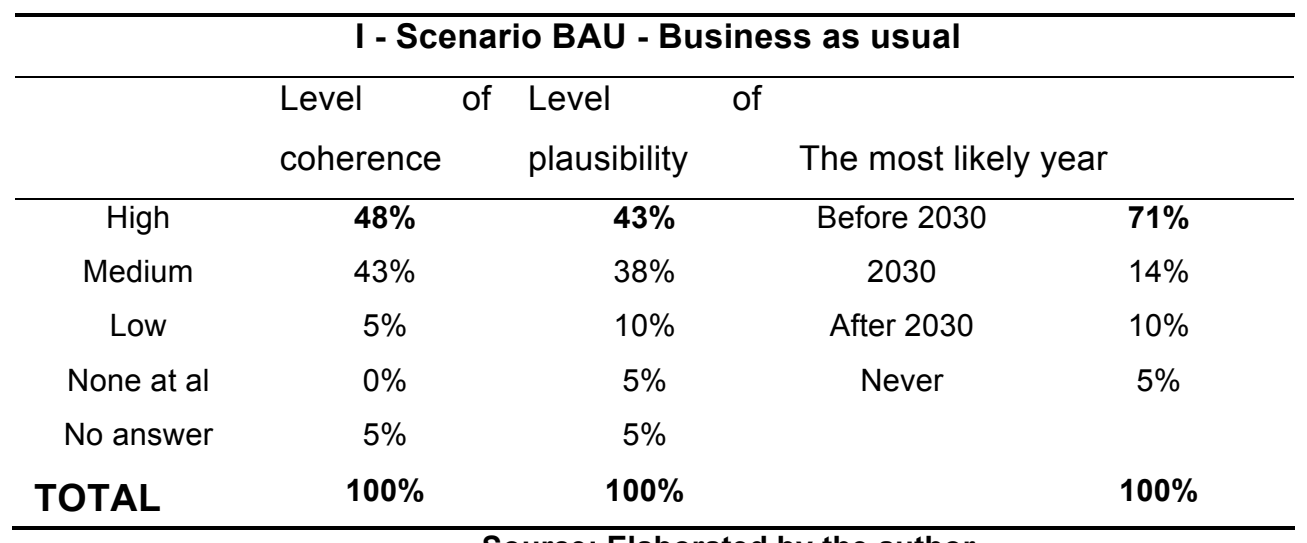

Source: Elaborated by the author

Table 19 - Results for scenario SBS

\begin{tabular}{ccccc}
\hline \multicolumn{4}{c}{ Il - Scenario SBS - Step-by-step } \\
\hline & $\begin{array}{c}\text { Level of } \\
\text { coherence }\end{array}$ & $\begin{array}{c}\text { Level of } \\
\text { plausibility }\end{array}$ & The most likely year \\
\hline High & $19.0 \%$ & $23.8 \%$ & Before 2030 & $14.3 \%$ \\
Medium & $\mathbf{4 7 . 6 \%}$ & $23.8 \%$ & 2030 & $28.6 \%$ \\
Low & $33.3 \%$ & $\mathbf{4 7 . 6 \%}$ & After 2030 & $\mathbf{5 2 . 4 \%}$ \\
None at al & $0.0 \%$ & $0.0 \%$ & Never & $0.0 \%$ \\
No answer & $0.0 \%$ & $4.8 \%$ & No answer & $4.8 \%$ \\
TOTAL & $\mathbf{1 0 0 \%}$ & $\mathbf{1 0 0 \%}$ & & $\mathbf{1 0 0 \%}$ \\
\hline
\end{tabular}

Source: Elaborated by the author 
Table 20 - Results for scenario ABC

\begin{tabular}{ccccc}
\hline \multicolumn{5}{c}{ III - Scenario ABC- Abundance } \\
\hline & $\begin{array}{c}\text { Level of } \\
\text { coherence }\end{array}$ & $\begin{array}{c}\text { Level of } \\
\text { plausibility }\end{array}$ & The most likely year \\
\hline High & $19.0 \%$ & $14.3 \%$ & Before 2030 & $9.5 \%$ \\
Medium & $\mathbf{4 2 . 9 \%}$ & $33.3 \%$ & 2030 & $14.3 \%$ \\
Low & $38.1 \%$ & $\mathbf{3 8 . 1 \%}$ & After 2030 & $\mathbf{6 1 . 9 \%}$ \\
None at al & $0.0 \%$ & $14.3 \%$ & Never & $14.3 \%$ \\
No answer & $0.0 \%$ & $0.0 \%$ & & \\
TOTAL & $\mathbf{1 0 0 \%}$ & $\mathbf{1 0 0 \%}$ & & $\mathbf{1 0 0 \%}$ \\
\hline
\end{tabular}

Source: Elaborated by the author

Table 21 - Results for scenario SCR

\begin{tabular}{ccccc}
\hline \multicolumn{4}{c}{ IV - Scenario SCR- Scarcity } \\
& $\begin{array}{c}\text { Level of } \\
\text { coherence }\end{array}$ & $\begin{array}{c}\text { Level of } \\
\text { plausibility }\end{array}$ & The most likely year \\
\hline High & $9.5 \%$ & $9.5 \%$ & Before 2030 & $4.8 \%$ \\
Medium & $42.9 \%$ & $19.0 \%$ & 2030 & $9.5 \%$ \\
Low & $\mathbf{4 7 . 6 \%}$ & $\mathbf{4 7 . 6 \%}$ & After 2030 & $\mathbf{4 2 . 9 \%}$ \\
None at al & $0.0 \%$ & $23.8 \%$ & Never & $\mathbf{4 2 . 9 \%}$ \\
No answer & $0.0 \%$ & $0.0 \%$ & & \\
TOTAL & $\mathbf{1 0 0 \%}$ & $\mathbf{1 0 0} \%$ & & $\mathbf{1 0 0 \%}$ \\
\hline
\end{tabular}

Source: Elaborated by the author

Table 22 - Summary of results for high and medium options

\begin{tabular}{|c|c|c|}
\hline \multicolumn{3}{|c|}{$\begin{array}{l}\text { Scenarios for Biodiesel Industry in Brazil, } \\
\qquad 2030\end{array}$} \\
\hline & $\begin{array}{c}\text { Level of } \\
\text { coherence (high } \\
+ \text { medium) }\end{array}$ & $\begin{array}{c}\text { Level of } \\
\text { plausibility (high } \\
+ \text { medium) }\end{array}$ \\
\hline$\overline{B A U}$ & $91 \%$ & $91 \%$ \\
\hline SBS & $66.6 \%$ & $47.6 \%$ \\
\hline $\mathrm{ABC}$ & $61.9 \%$ & $47.6 \%$ \\
\hline SCR & $52.4 \%$ & $28.5 \%$ \\
\hline
\end{tabular}

Source: Elaborated by the author

The scenario BAU was considered to be coherent, plausible and would occur before 2030. The Step by step, SBS and Abundance, ABC scenarios had similar percentages of 
agreement in high and medium coherence and plausibility. In addition, the participants considered these would happen after 2030. The final scenario; Scarcity, SCR, however, would happen after 2030 or not at all, according the 18 panellists. This scenario was considered to have low coherence and low plausibility. Table 22 summarizes the results for the two validation criteria.

The most coherent and plausible option can be easily identified as the BAU scenario. It has advances in biodiesel production, but weak response to climate change. Even though SBS and $A B C$ scenarios are opposite regarding the technological advances, they were perceived in almost the same way in terms of coherence and plausibility. This is interesting, considering that they both depend on strong response to climate change and environmental care. Finally, one can note that the panellists did not think the worst could happen, such as the scenario Scarcity, SCR. It seems they think it is more likely to have technological breakthrough (advanced fuel and engines), than more degradation and vulnerability due to climate change. Even though there are only two rounds of Delphi, the convergence occurred for $B A U$, SBS and $A B C$ considering the high and medium alternatives, and for SCR considering the medium and low alternatives. The Delphi result also showed the crystalized perceptions between technological advances and the effects of deforestation.

\subsubsection{Conclusion}

Transforming perceptions and opinions in scenarios storylines is not a trivial and involves dealing with many assumptions. Nevertheless, the validation stage brought to light some interesting viewpoints. It seems to be easier to believe in technological breakthrough, than in climate change mitigation. Hence, some question remains. Shall human beings continue to believe that the technology will solve all problems repeatedly? Which one is more plausibly: climate change or new technologies? The answers would be a sign that people still do not believe in climate change? Can they neither see nor understand the results of deforestation and degradation?

In addition to presenting a technique for developing the scenario storylines, the contribution of this work was also to show that the perception about the future continues to follow the trends of the present. The BAU scenario had the highest level of agreement. Even though the Scarcity scenario is much closer to BAU, the panellists believe more strongly that it might not happen. The final contribution is the scenarios themselves; they show possibilities for the best and for the worst future. Now, it is the time to make decisions to avoid the worst and to facilitate the best. That is what scenarios are made for: to aid in 
decision-making in order to avoid the worst-case scenario from becoming a reality, and to do what is necessary to reinforce the way it is desirable.

The commitment signed by 195 countries in COP21, to keep the global warming below $2^{\circ} \mathrm{C}$, the $\$ 100$ billion a year in climate finance for developing countries by 2020 , and the agreement about zero net emissions, even without a coercive mechanism to control, strengthen the $A B C$ and SBS scenarios. This can favoured biodiesel as an important role and a safe bridge to a low carbon economy.

\section{Contributions}

Dias wrote the manuscript, Vianna supervised, and Felby and Vianna discussed and made critical reviews.

\section{Acknowledges}

The authors thank to Professor Ole John Nielsen for helpful discussions and review. Also the authors thank people who participate in the pre-test for valuable critics, and the Delphi panellist to make the research possible.

\subsubsection{References}

Amer, M., Daim, T. U., \& Jetter, A. (2013). A review of scenario planning. Futures, 46(0), 2340. doi:http://dx.doi.org/10.1016/j.futures.2012.10.003

Bacovsky, D., Dallos, M., \& Wörgetter, M. (2010). Status of 2nd generation biofuels demonstration facilities in June 2010. Retrieved from http://library.certh.gr/libfiles/PDF/GEN-SPIN-711-STATUS-by-BACOVSKY-in-RPTBIOENERGY-TASK-39-PP-126-Y-JUL-2010.pdf

Bañuls, V. A., \& Turoff, M. (2011). Scenario construction via Delphi and cross-impact analysis. Technological Forecasting and Social Change, 78(9), 1579-1602. doi:10.1016/j.techfore.2011.03.014

Bishop, P., Hines, A., \& Collins, T. (2007). The current state of scenario development: an overview of techniques. Foresight, 9(1), 5-25. doi:10.1108/14636680710727516

Bradfield, R., Wright, G., Burt, G., Cairns, G., \& Van Der Heijden, K. (2005). The origins and evolution of scenario techniques in long range business planning. Futures, 37(8), 795-812. doi:http://dx.doi.org/10.1016/j.futures.2005.01.003

Brasil247. (2015). COM OBAMA, DILMA PROMETE DESMATAMENTO ILEGAL ZERO. Retrieved from http://www.brasil247.com/pt/247/mundo/186971/Com-Obama-Dilmapromete-desmatamento-ilegal-zero.htm

BRASIL/MAPA. (2014). Projections of Agribusiness : Brazil 2013/14 to 2023/24, long term projections (1). Retrieved from 
Brazil. (2012). Sector plan of mitigation and adaptation to climate change for low carbon emission economy in agriculture (in portuguese). Retrieved from Brazil:

Brazil. (2015). intended Nationally Determined Contribution towards achieving the objective of the United Nations framework convention on climate change. Retrieved from Brazil:

http://www4.unfccc.int/submissions/INDC/Published\%20Documents/Brazil/1/BRAZIL \%20iNDC\%20english\%20FINAL.pdf

Brazil/MAPA. (2012) ABC Plan- Plano setorial de mitigação e de adaptação às mudanças climáticas para a consolidação de uma economia de baixa emissão de carbono na agricultura. (pp. 173): MAPA - Mlnistry of Agriculture, Livestock and Suply.

Brazil/MDA (2015, 2015). [Performance report and targets plan Terra Legal Program and other Social Programs (in portuguese) ].

Brazil/MMA. (2012). Recuperação de Áreas Degradadas. Retrieved from http://www.mma.gov.br/comunicacao/item/8705-recuperação-de-áreas-degradadas

Brazil/MME. (2015). Projeto Ônibus Brasileiro a Hidrogênio. Retrieved from http://www.mme.gov.br/programas/onibus_hidrogenio/menu/projeto/sobre_projeto.ht $\underline{\mathrm{ml}}$

Brazil/MME/EPE. (2014). PNE2050_Premissas econômicas de longo prazo. Retrieved from

Brazil/MME/EPE. (2015). Balanço nacional de energia 2014. Retrieved from https://ben.epe.gov.br/downloads/Relatorio_Final_BEN_2015.pdf

Börjeson, L., Höjer, M., Dreborg, K.-H., Ekvall, T., \& Finnveden, G. (2006). Scenario types and techniques: Towards a user's guide. Futures, 38(7), 723-739. doi:10.1016/j.futures.2005.12.002

Chermack, T. J., Lynham, S. A., \& Ruona, W. E. A. (2001). A review of scenario planning literature. Futures Research Quartely. Retrieved from https://scienceimpact.mit.edu/sites/default/files/documents/Scenario\%20PlanningA\% 20Review\%20of\%20the\%20Literature.PDF

CONDRAF-National-council-of-sustainable-rural-development. (2014). Plano Nacional de desenvolvimento rural sustentável e solidário. PNDRSS. Retrieved from Brasil:

Diamond, J. (2011). Collapse: how societies choose to dail or succed (revised edition ed.). USA: Penguin Books.

Dias, M. A. d. P., Bentsen, N. S., \& Felby, C. (2015). The choice of feedstocks for producing biodiesel: a case study of Brazil. PhD thesis chapter. Centre for Sustainable Development and Department of Geosciences and Natual Resources Management, section for Forest, Nature and Biomass. University of Copenhagen and University of Brasilia.

Dias, M. A. d. P., \& Vianna, J. N. d. S. (2015). Sustainability in the prospective scenarios methods. PhD thesis chapter. Centre for Sustainable Development; Department of Geosciences and Natual Resources Management, section for Forest, Nature and Biomass. University of Brasilia and University of Copenhagen. Brasilia.

EBC-Brazilian-comunication-company. (2015). Dilma e Merkel assumem compromisso de reduzir emissão de gases de efeito estufa. Retrieved from 
http://www.ebc.com.br/noticias/internacional/2015/08/dilma-e-merkel-assumemcompromisso-de-reduzir-emissao-de-gases-de

EBC. (2015). São Paulo é o primeiro estado do país com ônibus a hidrogênio. Retrieved from http://www.ebc.com.br/tecnologia/2015/06/sao-paulo-e-o-primeiro-estado-dopais-com-onibus-movidos-hidrogenio

EMTU. (2015). Ônibus a Hidrogênio. $\quad$ Retrieved from http://www.emtu.sp.gov.br/emtu/empreendimentos/projetos-de-desenvolvimentotecnologico/onibus-a-hidrogenio.fss

Frederico, S. (2012). Agricultura científica globalizada e fronteira agrícola moderna no Brasil Confins on line, 17. doi:DOI : 10.4000/confins.8153

Garcez, C. A. G., \& Vianna, J. N. d. S. (2009). Brazilian Biodiesel Policy: Social and environmental considerations of sustainability. Energy, 34(5), 645-654. doi:http://dx.doi.org/10.1016/j.energy.2008.11.005

GBN. (2012). Developing and using scenarios, course material run in San Francisco, october, 2012.: GBN - global busines network.

Globo, G. (2015). Dilma promete reflorestar $120 \mathrm{mil} \mathrm{km}^{2}$ e zerar desmatamento ilegal até 2030. Retrieved from http://g1.globo.com/mundo/noticia/2015/06/dilma-assina-noseua-compromisso-para-zerar-desmatamento-ilegal.html

Godar, J. e. a. (2014). Actor-specific contributions to the deforestation slowdown in the Brazilian Amazon. . PNAS, 111(43). Retrieved from www.pnas.org/cgi/doi/10.1073/pnas.1322825111

Gordon, T. J. (2007). Energy forecasts using a "Roundless" approach to running a Delphi study. Foresight, 9(2), 27-35. doi:10.1108/14636680710737731

Hanafin, S. (2004). Review of literature on the Delph Technique. Retrieved from http://www.dcya.gov.ie/documents/publications/Delphi_Technique_A_Literature_Revi ew.pdf

Helmer, O. (1967). Systematic use of expert opinions. Retrieved from http://www.rand.org/content/dam/rand/pubs/papers/2006/P3721.pdf

Hsu, C.-C., \& Sandford, B. A. (2007). The Delphi technique: making sense of consensus. Practical assessment, research \& evaluation, 12(10).

IBGE. (2015a). Instituto Brasileiro de Geografia e Estatística. Retrieved from www.ibge.gov.br

IBGE. (2015b). Instituto Brasileiro de Geografia e Estatística - PAM - Pesquisa Agropecuária Municipal. Retrieved from www.ibge.gov.br

IEA. (2011). Technology Roadmap - biofuels for transport, 2050. Retrieved from www.iea.org

IMAZON. (2015). ONGs lançam manifesto público sobre a Agenda Brasil. Retrieved from http://imazon.org.br/imprensa/ongs-lancam-manifesto-publico-sobre-a-agenda-brasil/ 
INPE. (2015). PROJETO PRODES MONITORAMENTO DA FLORESTA AMAZÔNICA BRASILEIRA POR SATÉLITE Retrieved from http://www.obt.inpe.br/prodes/index.php

IPCC. (2014). Climate Change 2014; Synthesis Report. contribution of Working Groups I,II and III to the fifth Assessment Report of the Intergovernmental Panel on Climate Change. Retrieved from Geneva, Switzerland, 151pp: https://www.ipcc.ch/publications_and_data/ar4/wg3/en/contents.html

Landeta, J. (2006). Current validity of the Delphi method in social sciences. Technological Forecasting and Social Change, 73(5), 467-482. doi:10.1016/j.techfore.2005.09.002

Marcial, E. C., \& Grumbach, R. J. d. S. (2008). Grumbach method - strategic vision and consolidation (in portuguese) Prospective Scenarios, how to build a better future (in portuguese) (Fifth edition, revised and expanded ed., pp. 228). Rio de Janeiro: Editora FGV.

Maretti, C. C., Riveros S., J. C., Hofstede, R., Oliveira, D., Chrity, S., Granizo, T., . . . Thompson, C. (2014). State of the amazon: Ecological representation in prtected areas and indigenous territories. Retrieved from http://d2ouvy59p0dg6k.cloudfront.net/downloads/final_report_11_11_14.pdf

Millenium-project. (2006). The state of future - Global Energy Scenarios 2020. Retrieved from http://www.millennium-project.org/

Nationalgrid. (2015). Future energy scenarios - UK gas and electricity transmission. Retrieved from London, UK: www.nationalgrid.com

Ninio, M. (2015). Negociador de confiança de Obama crê em acordo global sobre clima. Retrieved from http://www1.folha.uol.com.br/mundo/2015/08/1672663-negociador-deconfianca-de-obama-cre-em-acordo-global-sobre-clima.shtml

Nobre, A. D. (2015). o futuro climático da Amazônia (The climate future of the Amazon). Retrieved from Brasil:

OECD-FAO. (2015). Agricultural Outlook 2015. Retrieved from Paris: http://dx.doi.org/10.1787/agr_outlook-2015-en

OECD/IEA. (2015). Key World Statistics 2015. Retrieved from http://www.iea.org/publications/freepublications/publication/key-world-energystatistics-2015.html

Pillkahn, U., \& Sasano, S. (2008). Scenario development 2.0. Paper presented at the Third International Seville Seminar on Future-Oriented TEchnology Analysis: impacts and implications for policy and decision-making, SEville.

Pincombe, B., Blunden, S., Pincombe, A., \& Dexter, P. (2013). Ascertaining a hierarchy of dimensions from time-poor experts: Linking tactical vignettes to strategic scenarios. Technological Forecasting and Social Change, 80(4), 584-598. doi:10.1016/j.techfore.2012.05.001

Porto, C. (2001). Modelos e cenarios para a Amazônia: o papel da ciência. Macrocenarios da Amazônia. Retrieved from Brasilia: http://www.macroplan.com.br/MonCenarios_Item.aspx?ld=3 
Powel, C. (2003). The Delphi Technique Myths and Realities. Methodological issues in nursing research - Journal of Advanced Nursing,, 41(4).

PWC. (2014). Two degrees of separation: ambition and reality. Low carbon economy index 2014. Retrieved from UK: www.co.uk

REN21. (2014). Global status report Retrieved from Paris: http://www.ren21.net/status-ofrenewables/global-status-report/?gclid=CliGrPmoxckCFQEoHwodujUGsQ

Rogers, E. M. (2003). Diffusion of Innovations (Fifth edition ed.). USA: Free Press.

Saúde-e-Sustentabilidade, I., \& APROBIO. (2015). Avaliação dos impactos na saúde e sua valoração devido à implementação progressiva do componente biodiesel na mistura da matriz energética (diesel) de transporte. Retrieved from São Paulo: www.aprobio.com.br

SEEG/OC. (2015). Synthesis document: analysis of the GHG in Brazil 1970-2013 and the implications to the public policies, 2014. Retrieved from São Paulo, Brazil: http://seeg.eco.br/analise-de-emissoes-brasileiras-de-gee-no-brasil-1970-2013/

Sousa, C. S. G. d. (2013). Cenários prospectivos da producao de biodiesel no Brasil, em 2020. (Master), Federal University of Paraiba, Paraiba, Brazil.

Sparovek, G., Barretto, A. G. O. P., Matsumoto, M., \& Berndes, G. (2015). Effects of governance on availability of land for agriculture and conservation in Brazil. Environmental science \& technology. doi:10.1021/acs.est.5b01300

Stitt-Gohdes, W. L., \& Crews, T. B. (2004). The delphi technique: a research strategy for career and technical education. Journal of Career and Technical Education, 20(2).

Tapio, P., Paloniemi, R., Varho, V., \& Vinnari, M. (2011). The unholy marriage? Integrating qualitative and quantitative information in Delphi processes. Technological Forecasting and Social Change, 78(9), 1616-1628. doi:10.1016/j.techfore.2011.03.016

Turoff, M. (1975). The policy Delphi The Delphi method: Techniques and applications. London: Addison-Wesley.

UNEP. (2015). The emissions gap report 2015 - executive summary. Retrieved from http://uneplive.unep.org/theme/index/13\#indcs

UNFCC. (2010). Copenhagen Climate Change Conference, decision -/CP.15. Retrieved from http://unfccc.int/meetings/copenhagen_dec_2009/meeting/6295/php/view/decisions.p hp

USA, E. O. o. e. e. r. e. (2015). HYDROGEN AND FUEL CELLS. Retrieved from http://energy.gov/eere/fuelcells/fuel-cell-technologies-office

USDOE-US-Department-of-Energy. (2014). HYDROGEN AND FUEL CELLS Program. 2014 annual progress report. Retrieved from http://energy.gov/eere/transportation/hydrogen-and-fuel-cells, 
USDOE-US-Department-of-Energy). (2009). Alternative Fuels \& Advanced Vehicles Data Center. Energy Efficiency and Renewable energy, . Retrieved from www.afdc.energy.gov/afdc/

Vaccaro, G. L. R., Pohlmann, C., Lima, A. C., dos Santos, M. S., de Souza, C. B., \& Azevedo, D. (2010). Prospective scenarios for the biodiesel chain of a Brazilian state. Renewable and Sustainable Energy Reviews, 14(4), 1263-1272. doi:http://dx.doi.org/10.1016/j.rser.2009.12.008

WEC, W. e. c. (2013). World Energy Scenarios: Composing energy futures to 2050. Retrieved from London, UK: https://www.worldenergy.org/publications/2013/worldenergy-scenarios-composing-energy-futures-to-2050/

WEC, W. e. c. (2015). New Zeland Energy Scenarios- navigating energy futures to 2050. Retrieved from New Zealand: https://www.bec.org.nz/projects/bec2050

Wilson, I. (1998). Mental maps of the future: an intuitive logics Approach to scenarios. In L. F. R. M. Randall (Ed.), Learning from the future - competitive Foresight Scenarios. USA: John Wiley \& sons, Ltd.

WORLDBANK. (2011). Brazil low carbon case study - technical Synthesis report: land use, land-use change, and forestry. Retrieved from

WORLDBANK. (2015). Global Economic Prospects. Retrieved from http://databank.worldbank.org/data/reports.aspx?source=global-economicprospects\#) 


\section{ANNEX IV: DELPHI QUESTIONNAIRE AND THE ANSWERS OF THE FIRST ROUND}

\section{Introduction: Scenarios For The Biodiesel Industry In Brazil, By 2030}

Welcome to this survey. This is an important part of a PhD Thesis about the future of biodiesel in Brazil, from University of Brasilia (Brazil) and University of Copenhagen (Denmark). The objective of this work is to provide information and alternatives for policy makers.

\section{PART 1}

First of all, would you please confirm your data filling out the form below. Even though the participants will be listed in the final version, individual answers will not be disclosed.

1.Name:

2.Job/position :

3. Organization/company:

4.Age:

5.Gender:

6.Level of education:

7. How do you classify yourself regarding your level of knowledge about the biodiesel market in Brazil:
a. know it deeply
b. know it in a medium level
c. Know it superficially
d. just like the subject

8. Which of the follow situations best represents your experience in the biodiesel market

e. W_ Work/study with biodiesel more than 3 years

f. Work/study with biodiesel less than 3 years

g. Work/study with subject related to biodiesel or biofuel (environment, land tiltling, land tenure, pollution, agriculture, climate change, etc)

h. _ other.

\section{PART 2:Instructions for responses}

Four scenarios were written based on two driving forces: technological advances and the intensity of the answers to the climate changes related to land use. These driving forces were identified in-deep interviews conducted between 2012 and 2014 . We looked for references to support the opinion of the interview participants, which are provided in a file attached (here). 
There are 3 kind of scenario descriptions: 1) complete description, 2) a briefly description, 3) a summary table. We kindly ask you that, based on the complete description, assess the coherence (logical and good relationship of cause and effect) and plausibility of each scenario.

VERY IMPORTANT: scenarios are not future forecasts, but storylines about the future.

The four scenarios are: Business as usual, Going to scarcity, Abundance, and Step by step. After having read and understood the scenarios, we ask you to answer the questions.

\section{Scenarios complete description:}

I. SCENARIO BAU: gradual technological advances and low answer to the climate change: Brazil didn't recover its degraded land, as it would be expected in ABC Plan (Low carbon agriculture). Even though there were a lot of reports about Amazon died back (transmutation to savannah or other biodiverse landscape) and all the direct consequences for the climate changes in the Brazilian Central region, the deforestation rate persists around 5000 $\mathrm{km}^{2} /$ year, or more. Some progress has been made regarding the production of soybean and other oilseeds more resistant to the dry season. Also, we have improved the efficiency of the biodiesel production process, but we continue to produce biodiesel mostly from soybean and beef tallow. Few other feedstocks have minor participation on the biodiesel feedstock matrix. The Brazilian economic and political situation is not stable enough to provide predictability for the biodiesel producers regarding the blend percentage. In addition to this, the increasing Chinese demand for soybean grains results in intense and tense negotiations between government and soybean producers. There was an expectation of producing biodiesel from palm oil, but most of it is used for food production and exportation. The only alternative is to adopt the second generation of biodiesel or decrease the mandatory blend. The second option will cause a lot of health damage, which society cannot accept. Therefore, we are experiencing a transition situation from biodiesel produced by oilseeds to advanced biodiesel, although it can be more expensive than biodiesel produced from vegetable oil and animal fat. The blend in big cities is greater the in other places, to avoid the cardiorespiratory diseases.

\begin{tabular}{|c|c|c|c|c|c|}
\hline \multicolumn{6}{|c|}{ 9. Scenario BAU } \\
\hline $\begin{array}{l}\text { 9.1 Level of } \\
\text { coherence: }\end{array}$ & $\begin{array}{l}\text { Global } \\
\text { results, 1st } \\
\text { round }\end{array}$ & $\begin{array}{c}9.2 \\
\text { Plausibility }\end{array}$ & $\begin{array}{l}\text { Global } \\
\text { results, 1st } \\
\text { round }\end{array}$ & $\begin{array}{l}9.3 \text { The } \\
\text { most likely } \\
\text { year: }\end{array}$ & $\begin{array}{l}\text { Global } \\
\text { results, 1st } \\
\text { round }\end{array}$ \\
\hline High & $58.8 \%$ & Good & $47.1 \%$ & by 2030 & $17.6 \%$ \\
\hline _Medium & $35.29 \%$ & _ Medium & $41.2 \%$ & $\begin{array}{l}\text { before } \\
2030\end{array}$ & $70.6 \%$ \\
\hline _Low & $5.88 \%$ & _Low & $5.9 \%$ & $\begin{array}{c}\text { after } \\
2030\end{array}$ & $5.9 \%$ \\
\hline & & Not at all & $5.9 \%$ & Never & $5.9 \%$ \\
\hline
\end{tabular}

II. SCENARIO Step by step: Gradual technology adoption, high answer to the climate change; better use of secondary land to produce oilseeds for biodiesel - regional production 
IV. SCENARIO Scarcity: Technological breakthrough, low answer to the climate change, delays in adopting new technologies. The cell fuel and hydrogen are already available in commercial scale. The second generation of biodiesel (called advanced biodiesel) wont survive any longer. Brazil did not accomplish its own targets to recover degraded land, as it was envisaged in ABC Plan (Low carbon agriculture plan) from 2012. In addition, the Forest Code and the Environmental Protection System (SNUC) were changed due to the bad economic situation from 2015 to 2017. What was foreseeing in IPCC 2014 did happen. Climate change impacts worsened in the central region of Brazil due to the increasing rate of deforestation in Amazon and to non-recovery of other planned areas. In 2030 there are a lot of problems regarding long dry season and extreme events. Amazon rainforest is really becoming a savannah (cerrado). China changed its soybean demand - is importing much more whole grains than soy meal. Other productive chains were not structure to produce biodiesel, therefore, there is a competition between producing biodiesel and exporting soybean grain. The opportunity to export biodiesel also was lost. First, because the EU countries demanded biofuel from second generation, and then the cell fuel and hydrogen became commercial viable. Brazil has few plants producing advanced biodiesel but the transport in world is being totally transformed. It seems that, besides be considered one of the villain of the climate change due to the deforestation of Amazon Forest, Brazil has lost the pace of innovation in alternative fuels.

Biodiesel became an important issue to avoid respiratory diseases in big cities; so, society wants to decrease the percentage of the blend. So, now there is a deadlock: soon, there will not be enough feedstock to produce biodiesel and there is no money to change all the transport system to use hydrogen. Will Brazil go back to mineral diesel?

\begin{tabular}{|c|c|c|c|c|c|}
\hline \multicolumn{6}{|c|}{ 12. Scenario SCARCITY } \\
\hline $\begin{array}{l}\text { 12.1 Level of } \\
\text { coherence: }\end{array}$ & $\begin{array}{l}\text { Global } \\
\text { results, 1st } \\
\text { round }\end{array}$ & $\begin{array}{c}12.2 \\
\text { Plausibility }\end{array}$ & $\begin{array}{l}\text { Global } \\
\text { results, } 1 \mathrm{st} \\
\text { round }\end{array}$ & $\begin{array}{l}\text { Global } \\
\text { results, 1st } \\
\text { round }\end{array}$ & $\begin{array}{l}\text { Global } \\
\text { results, 1st } \\
\text { round }\end{array}$ \\
\hline High & $11.8 \%$ & Good & $11.8 \%$ & by 2030 & $11.8 \%$ \\
\hline __Medium & $41.2 \%$ & _ Medium & $17.6 \%$ & $\begin{array}{l}\text { before } \\
2030\end{array}$ & $0 \%$ \\
\hline Low & $47.1 \%$ & Low & $47.1 \%$ & after 2030 & $52.9 \%$ \\
\hline \multicolumn{2}{|l|}{ ( } & Not at all & $23.5 \%$ & $=$ Never & $35.3 \%$ \\
\hline
\end{tabular}

\section{Briefly description:}

1. BUSINESS AS USUAL (BAU): This scenario assumes that the dynamic of doing business in the biodiesel industry continue to be the same. Gradual adoption to new technologies of producing biodiesel and delays in protecting environment and recovering degraded land. Therefore, by 2030 the biodiesel production still uses vegetal oils and animal fat. Other feedstock and/or production technology will have a small share of the market.

2. STEP BY STEP (SBS) - gradual adoption of technological advances (like in BAU scenario), but with focus on native vegetation protection. Recovering and using degraded land will make possible the inclusion of local oilseeds as biodiesel feedstock. This will change the industry dynamic promoting regional development and 
more social inclusion. The diversity of feedstock and land available will make easier the large-scale exports.

3. ABUNDANCE (A)- technological breakthrough will be commercial available, like hydrogen and fuel cells. By 2030 developed countries will start to employ them. In Brazil - that will have recovered degraded land and protected the Amazon rainforest, the biodiesel production will be plenty. But developed country wont import biodiesel. Brazil will have time and available funding to start innovation plans.

4. (Going to) SCARCITY (GS)- there will be a technological breakthrough like in $A B$ scenario. However, delays in protecting the environment and recovering degraded land, added to water and climate stress will worsen the Brazil's socioeconomic conditions. This situation won't allow the adoption of new technologies and can lead to the biodiesel scarcity.

\section{Summary table}

\begin{tabular}{|c|c|c|c|c|}
\hline & $\begin{array}{c}\text { Scenario I - } \\
\text { BAU }\end{array}$ & $\begin{array}{c}\text { Scenario IV - } \\
\text { STEP BY } \\
\text { STEP }\end{array}$ & $\begin{array}{l}\text { Scenario III - } \\
\text { ABUNDANCE }\end{array}$ & $\begin{array}{l}\text { Scenario II - } \\
\text { going to the } \\
\text { SCARCITY }\end{array}$ \\
\hline $\begin{array}{c}\text { Traditional } \\
\text { Biodiesel }\end{array}$ & $\begin{array}{l}\text { Oilseeds } \\
\text { (soybean) and } \\
\text { beef tallow }\end{array}$ & $\begin{array}{l}\text { Oilseeds } \\
\text { (soybean and } \\
\text { others) } \\
\text { Animal } \\
\text { residues( beef } \\
\text { tallow, pork } \\
\text { and chicken } \\
\text { fat) }\end{array}$ & 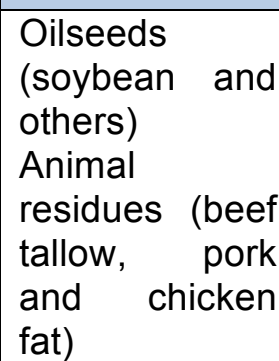 & $\begin{array}{l}\text { Oilseeds } \\
\text { (soybean) and } \\
\text { beef tallow }\end{array}$ \\
\hline $\begin{array}{c}\text { Second } \\
\text { generation of } \\
\text { biofuel }\end{array}$ & Just starting & Producing & $\begin{array}{l}\text { Producing as a } \\
\text { transition fuel }\end{array}$ & Delays \\
\hline $\begin{array}{l}\text { Breakthrough } \\
\text { (cell fuel, } \\
\text { hydrogen) }\end{array}$ & $\begin{array}{l}\text { Not } \\
\text { commercial } \\
\text { available }\end{array}$ & $\begin{array}{l}\text { Not } \\
\text { commercial } \\
\text { available }\end{array}$ & \begin{tabular}{|l} 
Commercial \\
available, \\
funding to \\
adopted the \\
new \\
technology
\end{tabular} & $\begin{array}{l}\text { Commercial } \\
\text { available, but } \\
\text { no adoption }\end{array}$ \\
\hline
\end{tabular}




\section{Questions. Feel free to comment all the questions in the space provide below each question}

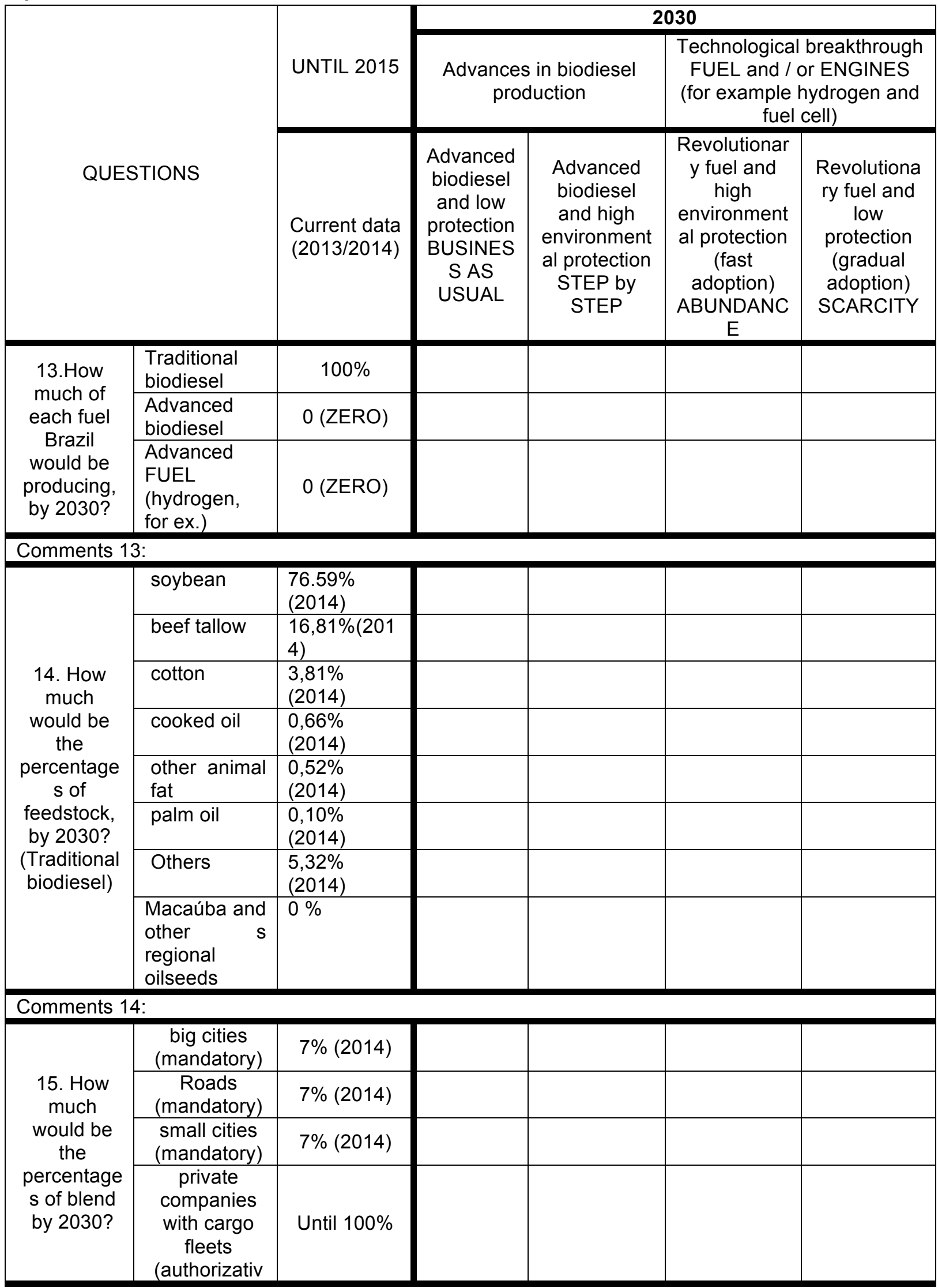




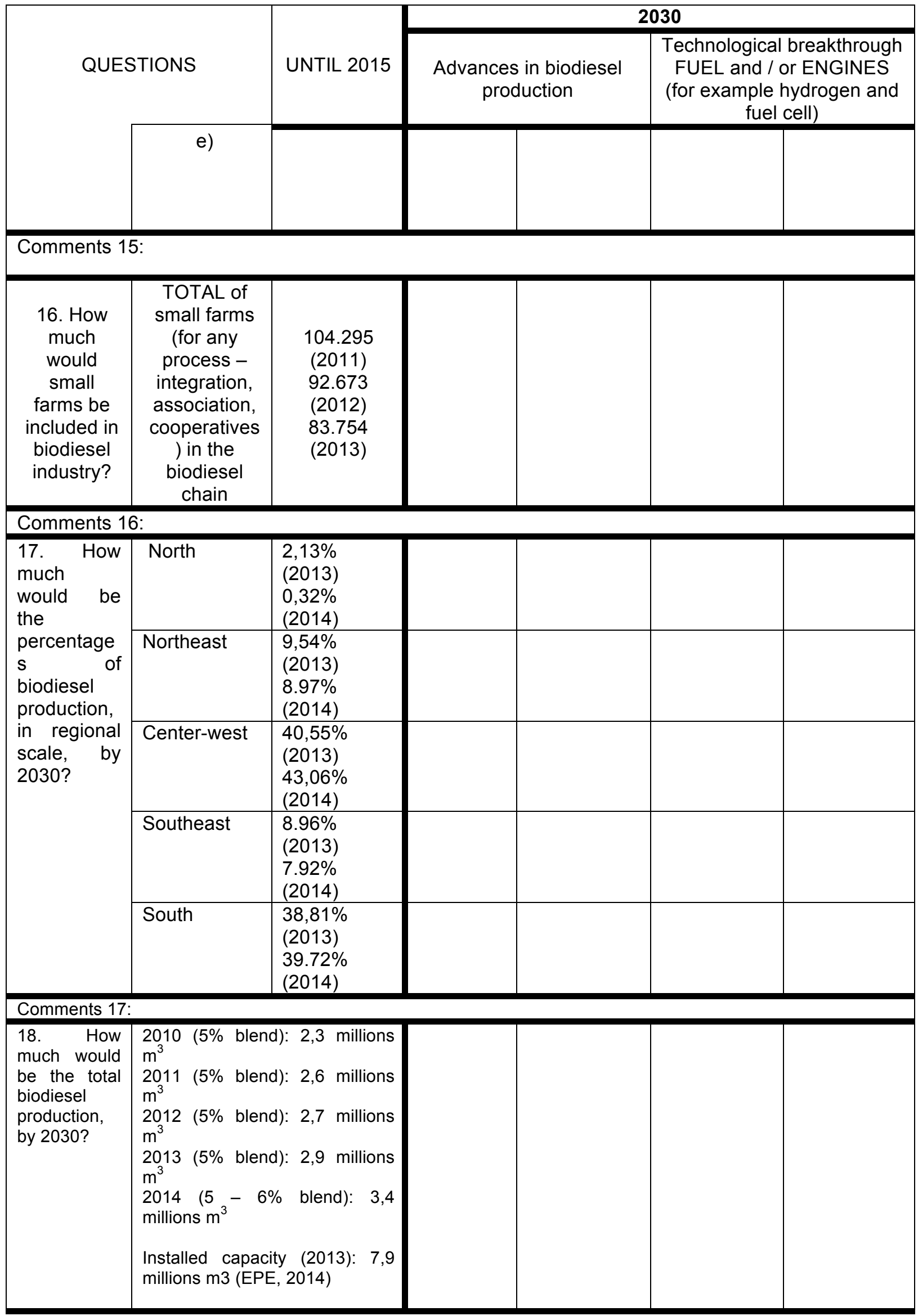




\begin{tabular}{|c|c|c|c|}
\hline \multirow{2}{*}{\multicolumn{2}{|c|}{ QUESTIONS }} & \multicolumn{2}{|c|}{2030} \\
\hline & & $\begin{array}{l}\text { Advances in biodiesel } \\
\text { production }\end{array}$ & $\begin{array}{c}\text { Technological breakthrough } \\
\text { FUEL and / or ENGINES } \\
\text { (for example hydrogen and } \\
\text { fuel cell) }\end{array}$ \\
\hline & $\begin{array}{l}\text { According to the National } \\
\text { energy ten-year plan (EPE, } \\
2014 \text { ), by } 2023 \text { the production } \\
\text { will be } 5.9 \text { millions } \mathrm{m}^{3} \text { (EPE, } \\
\text { 2014) }\end{array}$ & & \\
\hline Comments 18 & & & \\
\hline
\end{tabular}


ANNEX V: PEOPLE WHO CONTRIBUTED TO DELPHI PRE-TEST

Leonardo Conke - Portuguese - University of Brasilia

Moyses A Berndt - Portuguese - Bank of Brazil

Luciano Cunha de Sousa - Portuguese - Ministry of development, industry and foreign trade Ole John Nielsen - English - University of Copenhagen

Catherine Garcez - English - University of Brasilia

Celia Castro - Portuguese - Bank of Brazil

Antonio Sergio H Alves- Portuguese - University of Brasilia

Marcos Barbosa - Portuguese - Eletrobrás

Irlene Soares Silva - Portuguese - Health insurance company - CASSI 


\section{ANNEX VI DELPHI PANELLISTS}

\section{Ministries and Presidency of Republic of Brazil}

1. Ministry of Mines and Energy

a. Director of the department of renewable fuels: Ricardo de Gusmão Dornelles

b. General coordination of biofuel planning coordination of energy information: João Antônio Moreira Patusco.

2. Ministry of Agrarian Development

a. Bureau of Land Regularization in the Amazon/ Director of Planning, Monitoring and Evaluation Secretariat substitute - Marcio Hirata

b. Coordenação-Geral de Biocombustíveis CGBIO/DEGRAV/SAF/MDA - Marco Pavarino

3. Ministry of Agriculture, Livestock and Food Supply, Secretariat of Production and

Agroenergy

1. General coordinator of agroenergy: João da Silva Abreu Neto

4. Ministry of Science, Technology and Innovation. Secretariat of Technological development and innovation:

a. General coordination for sector Technologies Rafael Menezes, Energy R\&D Coordinator

5. Ministry of development, industry and foreign trade

Foreign trade coordinator: Luciano Cunha de Sousa

6. Presidency of Republic of Brazil,

Office of the chief of staff for the presidency - Jose Accarini, Assistant deputy chief for analysis and following up of government policies; substitute of the biodiesel federal program coordinator

Agency Oil, Energy company, and Agriculture and livestock research company of Brazil

7. ANP - National agency for petroleum natural gas and biofuels, Superintendence of biofuels and product quality:

- Rosângela Moreira de Araújo (Superintendent of Biofuels and Product Quality ) and her team (Fernanda Vieira Pinto, Marcela Flores, Jackson Albuquerque, Cristiane)

8. Brazil Energy Research Company EPE (linked to Ministry of Mines and Energy)

- Team responsible for Bioenergy Research :Pedro Ninô de Carvalho and Euler João Geraldo da Silva

9. Brazilian Agricultural Research Corporation - Agroenergy

- Manoel Teixeira Souza Jr. Director-general

\section{Producers}

10. APROBIO- Brazilian association of biodiesel producers 
- Julio Cesar Minelli - Superintendent Director

11. UBRABIO Brazilian association of biodiesel

- Professor Doctor Donato Aranda, Assessor (also professor at Federal University of Rio de Janeiro)

12. Evonik - Jose Berger

13. Ecodendê - Marcia Tagore

\section{Employees}

14. National Confederation of Agriculture Workers

- Antoninho Rovaris - Environment Secretary

\section{Congressmen}

- President of Parliamentary Front Biodiesel: Deputy Evandro Gussi

\section{Professors, researches}

a) University of Viscosa: Ronaldo Perez

b) University of Copenhagen: Ole John Nielsen

c) Catholic University of Minas: Professor Ricardo Sodré

d) University of Brasilia: Professor João Nildo de Souza Vianna, Antonio Sergio Hadad Alves

e) Professor Manfred Nitsch

f) University of Campinas: Professor Demóstenes Barbosa da Silva

17. Dealers

a. Ricardo R A X Menezes - vice president of Union of Brazilian regional distributors of fuels

b. Sandro Paes - Petrobrás

18. IISD- International Institute for Sustainable Development, Scott Vaughan - President and Chief Executive Officer - 


\section{EPILOGUE}

\subsection{CONCLUSIONS}

What are the possibilities for producing biodiesel in Brazil, by 2030 ? The alternatives could follow current trajectories made in developing countries where energy consumption in tied closely to economic growth, somewhat, tempered by efficiency gains. Thus, a very simple and swift answer would be that the biodiesel production will increase and energy efficiency will be enhanced. However, the interest of this work was to know the possibilities of producing biodiesel in Brazil, by 2030, considering the dimensions of sustainability. The intention was not only to understand the dynamics for increasing the production and use of biodiesel, but whether or not the production could be sustainable in a sense of not motivate deforestation, not compete for land with food, to promote social and regional development and so on. The study of such possibilities presented various challenges.

First, what is the status of biodiesel production today? Is there any real possibility to change it? Is change necessary? To answer these questions, the first manuscript was written, in chapter 3, section 3.1: The choice of feedstock for producing biodiesel, a case of Brazil. Brazilian biodiesel is on a good path since it is primarily made from by-products; soybean oil and cotton oil; and residues such as animal fats and waste cooking oil. Nevertheless, the conclusion of the simulations made with linear programming models showed that it was possible to improve the production. Indeed, it is possible to produce it differently, improving the competitiveness and the stability of the market, contributing to regional development, recovering degraded land, and improve the environmental gains. It is necessary to take advantages of local oilseeds adapted to the conditions of each region of the country, increasing the palm oil share, and adding a higher percentage of residues.

After these conclusions, it was necessary to define a method for developing scenarios that could include the insights of sustainability. This was the objective of the second manuscript in chapter 3 , section 3.2: Sustainability in the prospective scenarios methods: a practical application of scenarios for biodiesel in Brazil, for 2030. After the scenario method was chosen, it was necessary to complete a theoretical discussion in order to modify its structure. The sustainability framework was crucial to give a comprehensive vision of reality and provide elements for a future that would include intergenerational solidarity. A practical exercise was also necessary to test the new methodology. Thus, all the conclusions of the first manuscript added with sustainable dimensions were the subject of in-depth interviews. The summary of the perceptions about the driving forces of change were listed and from them, the critical uncertainties have been identified. The result was that the social, environmental and economic aspects are linked to others like the territorial, social and 
political, in the composed uncertainty called level of response to climate changes and environmental conservation. This result was very intriguing. The expansion of the agriculture sector (on which biodiesel depends) is expected to happen in the North and Northeast regions - in Amazon and Cerrado biomes. These areas are also the stage of a complex and conflicting situation. The Amazon Forest is world's largest rainforest; it has the largest river basin on the planet and the biggest hydroelectric potential left in Brazil; it probably harbours $10 \%$ of the world's known species and contains $10 \%$ of the global reserve of carbon stored in its diverse ecosystem. The forest is home to 34 million people, including 385 indigenous groups ${ }^{30}$. There are on-going disputes regarding territories for indigenous reserve, traditional communities, illegal logging, land grabbing, small farmers and big companies, just to mention few. Hence, going forward, to produce oilseeds for biodiesel in Brazil, there are essentially two alternatives: converting native vegetation in the Amazon and Cerrado biomes or restoring degraded lands and using marginal lands all over the entire country. Which option will be chosen depends on the level of response to climate change and environmental conservation. Adding technological advances onto the above mentioned uncertainty there are critical uncertainties for the future possibilities to produce biodiesel in Brazil, by 2030.This framework was the core of the result of the manuscript in section 3.2 Sustainability in the prospective scenarios methods: a practical application of scenarios for biodiesel in Brazil, for 2030.

The last step of the present work was to address another challenge elaborated upon in the third manuscript: Integrating driving forces into storylines - a case of scenarios for the biodiesel industry in Brazil, for 2030 (chapter 3, section 3.3). The scenario method chosen, the GBN matrix included workshops to develop the storylines. However, the target audience of the interviews were located in various areas of the country and it would be very difficult to have everyone present together. Moreover, it was necessary to give academic consistency to the storylines, which were not result of an official workshop. Thus, an alternate technique was developed for the storylines: first, the assumptions for the timeline of 2030 were formulated based on the data gathered, studies and status of the critical uncertainties; finally, the scenarios storylines were developed. After this final step, they were submitted to the panellists in a Delphi survey, to validate the coherence and plausibility of the scenarios.

The four scenarios for the biodiesel industry in Brazil, for 2030 are:

a) Business as usual (BAU) - that considers the current dynamic of the biodiesel industry;

\footnotetext{
${ }^{30}$ For references see : (Macedo \& Castello, 2015; Maretti et al., 2014)
} 
b) Step by step (SBS) - this brings the sustainability option for biodiesel industry with benefits in terms of environment, social, and regional inclusion;

c) Abundance (ABC) - that takes advantage of technological breakthrough added to the sustainability alternative of Step by step scenario;

d) Scarcity (SCR) - that shows the deterioration of the current situation, with little care with environment, no degraded land restoration and few technological advances in biodiesel production.

In the validation process, the most coherent and plausible scenario was identified as the BAU scenario. It has advances in biodiesel production, but weak response to climate change. Even though SBS and $A B C$ scenarios are opposite regarding the technological advances, they were perceived in almost the same way in terms of coherence and plausibility. This is interesting, considering that they both depend on strong response to climate change and environmental conservation. Finally, one can note that the panellists did not think the worst could happen, such as the scenario Scarcity, SCR. This validation stage brought to light some interesting viewpoints. It seems to be easier to believe in technological breakthrough, than in climate change mitigation. Hence, some question remains. Shall human beings continue to believe that the technology will solve all problems repeatedly? Which one is more plausibly: climate change or new technologies? Would the answers be a sign that people still do not believe in climate change? Can they neither see nor understand the results of deforestation and degradation?

The commitment signed by 195 countries in COP21, to keep the global warming below $2^{\circ} \mathrm{C}$, the $\$ 100$ billion a year in climate finance for developing countries by 2020 , and the agreement about zero net emissions, even without a coercive mechanism to control, strengthen the $\mathrm{ABC}$ and SBS scenarios. In conclusion, the results of the present study may be useful for the policy makers in order to know what actions can be taken to achieve sustainable biodiesel industry in the future. Nevertheless, it is likely that the most important piece is to know what decision-makers should avoid in order to prevent the Scarcity scenario and the resource depletion in such a wealthy country like Brazil. After all, the best way to predict the future is to build it. Taking the right way, biodiesel may help to do a safe transition to a low carbon economy and to stop the climate warming at the $2^{\circ} \mathrm{C}$ level.

\subsection{SUGGESTIONS FOR THE NEXT RESEARCH}

Many other subjects related to biodiesel production and to feedstock would be studied in order to clarify the relationship between the agriculture and bioenergy markets. Here are some suggestions. 
It would be valuable and interesting to analyse the impacts of the scenarios of the simulations in terms of $\mathrm{CO}_{2}$ emissions, social inclusion and income generation. In addition, the evolving prices and demand of the feedstock considered in the simulations should undergo an economic evaluation. Furthermore, there are some hypotheses that the biodiesel production, as a by-product, helps to stabilize the prices of the commodities like soybean, rapeseed and cotton (cake and fibre). This point also deserves to be verified through research. Analysing the dynamic of the soybean, cotton and meat commodity markets, i.e. prices, imports, exports and stocks, should be studied regarding their relation to global biodiesel production. More comprehensive issue would be the correlation between hunger and the land use considering food, feed and biofuel production, in each region of the world.

The suggestions to the policy makers, is to analyse the set of scenarios. They are useful to avoid mistakes and to help make decisions to have a better future. In particular Scarcity scenario show the relationship between the effects of climate change to the economy and in the agriculture production. 


\section{REFERENCES}

ABIOVE. (2015). Balanco de Oferta/Demanda (1000t). Retrieved from http://www.abiove.org.br/site/_FILES/Portugues/03112015-120354-2015-11-03__quadro_de_oferta_e_demanda.pdf

Acquaye, A. A., Sherwen, T., Genovese, A., Kuylenstierna, J., Lenny Koh, S. C., \& McQueen-Mason, S. (2012). Biofuels and their potential to aid the UK towards achieving emissions reduction policy targets. Renewable and Sustainable Energy Reviews, 16(7), 5414-5422. doi:http://dx.doi.org/10.1016/j.rser.2012.04.046

Ajanovic, A., \& Haas, R. (2014). On the future prospects and limits of biofuels in Brazil, the US and EU. Applied Energy, 135, 730-737. doi:10.1016/j.apenergy.2014.07.001

Amer, M., Daim, T. U., \& Jetter, A. (2013). A review of scenario planning. Futures, 46(0), 23-40. doi:http://dx.doi.org/10.1016/j.futures.2012.10.003

Andres Quintero, J., Ruth Felix, E., Eduardo Rincón, L., Crisspín, M., Fernandez Baca, J., Khwaja, Y., \& Cardona, C. A. (2012). Social and techno-economical analysis of biodiesel production in Peru. Energy Policy, 43, 427-435. doi:http://dx.doi.org/10.1016/j.enpol.2012.01.029

Angarita, E. E. Y., Lora, E. E. S., Costa, R. E., Lamônica, H. m., Finguerut, J., Ramirez, G. A. S., \& Nascimento, M. A. R. (2008). Production of vegetable oils and biodiesel: technology and lifecycle assessment (in Portuguese). In L. A. B. Cortez, E. E. S. Lora, \& E. Gómez (Eds.), Biomass for energy ( in Portugues) (pp. 734). Campinas: Editora Unicamp.

ANP. (2015a). Agência Nacional do Petróleo. Retrieved from http://www.anp.gov.br

ANP. (2015b). Biocombustíveis. Retrieved from http://www.anp.gov.br

ANP. (2015c). Boletim mensal biodiesel. Retrieved from Brasilia: http://www.anp.gov.br/?pg=69299\&m=\&t1=\&t2=\&t3=\&t4=\&ar=\&ps=\&1449232987717

ANP, P. N. A. (2014). Brazilian statistical yearbook of oil, gas and biofuel 2014.

Antunes, E. C., Zuppa, T. O., Antoniosi Filho, N. R., \& Castro, S. S. (2006). Utilização do pequi (Caryocar brasiliense camb) como espécie recuperadora de ambientes degradados no cerrado e fornecedora de materia prima para a producao de biodiesel. Paper presented at the I congresso da rede brasileira de tecnologia do biodiesel, Brasília. http://www.agencia.cnptia.embrapa.br/Repositorio/pequi1_000g6vgwdq802wx5ok0wtedt3 zzxcrff.pdf

Axelsson, E., Harvey, S., \& Berntsson, T. (2009). A tool for creating energy market scenarios for evaluation of investments in energy intensive industry. Energy, 34(12), 2069-2074. doi:10.1016/j.energy.2008.08.017

Bacovsky, D., Dallos, M., \& Wörgetter, M. (2010). Status of 2nd generation biofuels demonstration facilities in June 2010. Retrieved from http://library.certh.gr/libfiles/PDF/GEN-SPIN-711STATUS-by-BACOVSKY-in-RPT-BIOENERGY-TASK-39-PP-126-Y-JUL-2010.pdf 
Bañuls, V. A., \& Turoff, M. (2011). Scenario construction via Delphi and cross-impact analysis. Technological Forecasting and Social Change, 78(9), 1579-1602. doi:10.1016/j.techfore.2011.03.014

Barros, G. S. C., Alves, L. R. A., \& Osaki, M. (2009). Necessidades de investimentos e otimizacao da producao agropecuaria com o programa de biodiesel no Brasil. Paper presented at the SOBER 47o. congresso da sociedade brasileira de economia, administracao e sociologia rural., Porto Alegre, RS.

Barros, G. S. C., Silva, A. P., Ponchi, L. A., Alves, L. R. A., Osaki, M., \& Cenamo, M. (2006). Custos de producão de biodiesel no Brasil. Revista da Política Agrícola, 3, 36-50.

Barros, G. S. C., Silva, A. P., Ponchi, L. A., Alves, L. R. A., Osaki, M., \& Cenamo, M. (2015). Biofuels, food security and compensatory subsidies. China Agricultural Economic Review, 2(4), 433455. doi:10.1108/17561371011097740, 10.1108/14777831011077646, 10.1108/IJSSP-012013-0002, 10.1108/IJESM-03-2013-0001

Bateson, G. (1972). Part III- A theory of play and fantasy Steps to an ecology of mind (pp. 541). New York, USA: Ballatine Books.

BECKER, W. A., SPENCER, J. V., MIROSH, L. W., \& VERSTRATE, J. A. (1979). Prediction of Fat and Fat Free Live Weight in Broiler Chickens Using Backskin Fat, Abdominal Fat, and Live Body Weight. Poultry Science, 58(4), 835-842. doi:10.3382/ps.0580835

Bergmann, J. C., Tupinambá, D. D., Costa, O. Y. A., Almeida, J. R. M., Barreto, C. C., \& Quirino, B. F. (2013). Biodiesel production in Brazil and alternative biomass feedstocks. Renewable and Sustainable Energy Reviews, 21(0), 411-420. doi:http://dx.doi.org/10.1016/j.rser.2012.12.058

Bishop, P., Hines, A., \& Collins, T. (2007). The current state of scenario development: an overview of techniques. Foresight, 9(1), 5-25. doi:10.1108/14636680710727516

Bolger, F., Stranieri, A., Wright, G., \& Yearwood, J. (2011). Does the Delphi process lead to increased accuracy in group-based judgmental forecasts or does it simply induce consensus amongst judgmental forecasters? Technological Forecasting and Social Change, 78(9), 1671-1680. doi:10.1016/j.techfore.2011.06.002

Bolger, F., \& Wright, G. (2011). Improving the Delphi process: Lessons from social psychological research. Technological Forecasting and Social Change, 78(9), 1500-1513. doi:10.1016/j.techfore.2011.07.007

Börjeson, L., Höjer, M., Dreborg, K.-H., Ekvall, T., \& Finnveden, G. (2006). Scenario types and techniques: Towards a user's guide. Futures, 38(7), 723-739. doi:10.1016/j.futures.2005.12.002

BP Energy Outlook 2035. (2015). Retrieved from http://www.bp.com

Bradfield, R., Wright, G., Burt, G., Cairns, G., \& Van Der Heijden, K. (2005). The origins and evolution of scenario techniques in long range business planning. Futures, 37(8), 795-812. doi:http://dx.doi.org/10.1016/j.futures.2005.01.003 
Brasil247. (2015). COM OBAMA, DILMA PROMETE DESMATAMENTO ILEGAL ZERO. Retrieved from http://www.brasil247.com/pt/247/mundo/186971/Com-Obama-Dilma-prometedesmatamento-ilegal-zero.htm

Brazil. (2007). PNE Plano Nacional de Energia, combustíveis líquidos, 2030. Retrieved from http://www.epe.gov.br/PNE/20080111_1.pdf

BRAZIL. (2010a). Programa Federal de Produção Sustentável de Óleo de Palma (PSOP). Retrieved from

http://www.agricultura.gov.br/arq_editor/file/camaras_setoriais/Palma_de_oleo/1_reuniao /Programa.pdf

Brazil. (2010b). Programa Federal de Produção Sustentável de Óleo de Palma (PSOP). Retrieved from

http://www.agricultura.gov.br/arq_editor/file/camaras_setoriais/Palma_de_oleo/1_reuniao /Programa.pdf

Brazil. (2012a). Recuperação de Áreas Degradadas. Retrieved from http://www.mma.gov.br/comunicacao/item/8705-recupera\%C3\%A7\%C3\%A3o-de-

\%C3\%A1reas-degradadas

Brazil. (2012b). Sector plan of mitigation and adaptation to climate change for low carbon emission economy in agriculture (in portuguese). Retrieved from Brazil:

Brazil. (2012c). Selo Combustível Social. Retrieved from http://www.mda.gov.br

Brazil. (2013). Brazilian Statistical Yearbook of Agrienergy 2012. Retrieved from Brasilia:

Brazil. (2014a). Adaptação às mudancas climaticas no Brasil: cenarios e alternativas - Energia. Retrieved from Brasilia: http://www.sae.gov.br/imprensa/noticia/brasil-2040-cenarios-ealternativas-de-adaptacao-a-mudanca-do-clima/

Brazil. (2014b). Projections of Agribusiness : Brazil 2013/14 to 2023/24, long term projections (1). Retrieved from

Brazil. (2015a). Balanço nacional de energia $2014 . \quad$ Retrieved from https://ben.epe.gov.br/downloads/Relatorio_Final_BEN_2015.pdf

Brazil. (2015b). intended Nationally Determined Contribution towards achieving the objective of the United Nations framework convention on climate change. Retrieved from http://www4.unfccc.int/submissions/INDC/Published Documents/Brazil/1/BRAZIL iNDC english FINAL.pdf

Brazil. (2015c). Plano decenal de expansão de energia 2024. Retrieved from Brazil: http://www.epe.gov.br/PDEE/PDE 2024.pdf

Brazil. (2015d). Portaria 516/2015. Brasilia: Diário Oficial.

Brazil. (2015e). Projeto Ônibus Brasileiro a Hidrogênio. Retrieved from http://www.mme.gov.br/programas/onibus_hidrogenio/menu/projeto/sobre_projeto.html 
Brazil/MAPA. (2012) ABC Plan- Plano setorial de mitigação e de adaptação às mudanças climáticas para a consolidação de uma economia de baixa emissão de carbono na agricultura. (pp. 173): MAPA - MInistry of Agriculture, Livestock and Suply.

Brazil/MDA (2015, 2015). [Performance report and targets plan Terra Legal Program and other Social Programs (in portuguese)].

Brazil/MME/EPE. (2006). PNE 2030 plano nacional de energia Retrieved from Brazil:

Brazil/MME/EPE. (2014). PNE2050_Premissas econômicas de longo prazo. Retrieved from

Brindraban, P. S., Bulte, E. H., \& Conijin, S. G. (2009). Can large-scale biofuels production be sustainable by 2020? Agricultural Systems, 101(3), 197-199.

Castro, A. M. G. d., \& Lima, S. M. V. (2010). The Brazilian agri-industrial complex of the biodiesel production (in portuguese). In A. M. G. d. Castro, S. M. V. Lima, \& J. F. V. Silva (Eds.), Complexo Agroindustrial de Biodiesel no Brasil: competitividade das cadeias produtivas de matérias-primas (1a. ed., pp. 712). Brasília: Embrapa Agroenergia.

César, A. d. S., \& Batalha, M. O. (2013). Brazilian biodiesel: The case of the palm's social projects. Energy Policy, 56, 165-174. doi:http://dx.doi.org/10.1016/j.enpol.2012.12.014

Chatterjee, R., Sharma, V., Mukherjee, S., \& Kumar, S. (2014). Quantitative assessment of biodiesel production: A model-based scenarios of sustainable development. Journal of Renewable and Sustainable Energy, 6(1), 013129. doi:doi:http://dx.doi.org/10.1063/1.4863988

Chermack, T. J. (2005). Studying scenario planning: Theory, research suggestions, and hypotheses. Technological Forecasting and Social Change, 72(1), 59-73. doi:10.1016/s00401625(03)00137-9

Chermack, T. J., Lynham, S. A., \& Ruona, W. E. A. (2001). A review of scenario planning literature. Futures Research Quartely.

CNT. (2015). Transport Statistical Report (in portuguese). Retrieved from Brasilia: http://www.cnt.org.br/Paginas/Boletins_Detalhes.aspx?b=3

CONAB. (2015a). Companhia nacional de abastecimento. Retrieved from http://www.conab.gov.br

CONAB. (2015b). Levantamento de Safra. Retrieved from http://www.conab.gov.br/conteudos.php?a=1253\&

CONDRAF-National-council-of-sustainable-rural-development. (2014). Plano Nacional de desenvolvimento rural sustentável e solidário. PNDRSS. Retrieved from Brasil:

Costa, A. O., Oliveira, L. B., Lins, M. P. E., Silva, A. C. M., Araujo, M. S. M., Pereira Jr, A. O., \& Rosa, L. P. (2013). Sustainability analysis of biodiesel production: A review on different resources in Brazil. Renewable and Sustainable Energy Reviews, 27, 407-412. doi:10.1016/j.rser.2013.06.005

Costa Neto, P. R., \& Rossi, L. F. S. (2000). Produção de biocombustivel alternativo ao óleo diesel atraves da transesterificação de oleo de soja usado em frituras. Quimica nova, 23(4). 
Cremonez, A. P., Feroldi, M., Cézar Nadaleti, W., de Rossi, E., Feiden, A., de Camargo, M. P., . . Klajn, F. F. (2015). Biodiesel production in Brazil: Current scenario and perspectives. Renewable and Sustainable Energy Reviews, 42(0), 415-428. doi:http://dx.doi.org/10.1016/j.rser.2014.10.004

Daly, H. E., \& Farley, J. (Eds.). (2004). Ecological Economics Principles and Applications. Washigton, USA: Island Press.

Dator, J. A. (1979). The futures of cultures and cultures of the future. In M. T., T. Ciborowski, \& R. Tharp (Eds.), Perspectives on Cross Cultural Psychology. New York: Academic Press.

Diamond, J. (2011). Collapse: how societies choose to dail or succed (revised edition ed.). USA: Penguin Books.

Dias, M. A. d. P., Alves, A. S. H., \& Vianna, J. N. d. S. (2015). A pathway to energy and food security with biodiesel. Journal of Sustainable Development of Energy, not plublish yet.

Dias, M. A. d. P., Bentsen, N. S., \& Felby, C. (2015). The choice of feedstocks for producing biodiesel: a case of Brazil. PhD thesis chapter. Centre for Sustainable Development and Department of Geosciences and Natual Resources Management, section for Forest, Nature and Biomass. University of Copenhagen and University of Brasilia.

Dias, M. A. d. P., \& Vianna, J. N. d. S. (2015). Sustainability in the prospective scenarios methods: a practical application of scenarios for biodiesel in Brazil, 2030. PhD thesis chapter. Centre for Sustainable Development; Department of Geosciences and Natual Resources Management, section for Forest, Nature and Biomass. University of Brasilia and University of Copenhagen. Brasilia.

DNIT. (2012). Report of federal highways (in Portuguese). Retrieved from Brasilia: http://www.dnit.gov.br/download/planejamento-e-pesquisa/planejamento/evolucao-damalha-rodoviaria/relatorio-sgp-2012-2013-brasil.pdf

Doman, L., \& Chase, N. (2015). Passenger travel accounts for most of world transportation energy use. Retrieved from https://www.eia.gov/todayinenergy/detail.cfm?id=23832

Duncan, J. (2003). Energy Efficieny and Conservation Authority. Retrieved from New Zeland:

Durance, P., \& Godet, M. (2010). Scenario building: Uses and abuses. Technological Forecasting and Social Change, 77(9), 1488-1492. doi:http://dx.doi.org/10.1016/j.techfore.2010.06.007

Dutra Jr, W., Ferreira, A. S., Tarouco, J. U., Euclydes, R. F., Donzele, J. L., Lopes, P. S., \& Cardoso, L. L. (2001). Estimativas de Rendimentos de Cortes Comerciais e de Tecidos de Suínos em Diferentes Pesos de Abate pela Técnica de Ultra-sonografia em Tempo Real. Revista Brasileira de Zootecnia, 30(4). doi:http://dx.doi.org/10.1590/S1516-35982001000500017

EBC. (2015a). Dilma e Merkel assumem compromisso de reduzir emissão de gases de efeito estufa. Retrieved from http://www.ebc.com.br/noticias/internacional/2015/08/dilma-e-merkelassumem-compromisso-de-reduzir-emissao-de-gases-de

EBC. (2015b). São Paulo é o primeiro estado do país com ônibus a hidrogênio. Retrieved from http://www.ebc.com.br/tecnologia/2015/06/sao-paulo-e-o-primeiro-estado-do-pais-comonibus-movidos-hidrogenio 
EIA. (2015a). International energy statistics. Retrieved from http://www.eia.gov/cfapps/ipdbproject/iedindex3.cfm?tid=79\&pid=81\&aid=1\&cid=regions, \&syid $=2000 \&$ eyid $=2012 \&$ unit $=$ TBPD

EIA. (2015b). U.S. Energy Information Administration. Retrieved from http://www.eia.gov

El Sawy, O. A., \& Pauchant, T. C. (1988). Triggers, templates and twitches in the tracking of emerging strategic issues. Strategic Management Journal, 9, 455-473.

Elkington, J. (1994). Towards the sustainable corporation: win-win-win business strategies for sustainable development. California Management Review, 36(2).

Elkington, J. (1998). Parnerships from cannibals with forks: the triple bottom line of $21^{\text {st }}$ century business. Environmental quality management(Autumn).

EMTU. (2015). Ônibus a Hidrogênio. Retrieved from http://www.emtu.sp.gov.br/emtu/empreendimentos/projetos-de-desenvolvimentotecnologico/onibus-a-hidrogenio.fss

Englund, O., Berndes, G., Martin Persson, U., \& Sparovek, G. (2015). Oil palm for biodiesel in Brazilrisks and opportunities. Environmental Research Letters, 10(4), 044002. doi:10.1088/17489326/10/4/044002

European-Commission. (2014). COMMUNICATION FROM THE COMMISSION TO THE EUROPEAN PARLIAMENT, THE COUNCIL, THE EUROPEAN ECONOMIC AND SOCIAL COMMITTEE AND THE COMMITTEE OF THE REGIONS

A policy framework for climate and energy in the period from 2020 to 2030 . Retrieved from http://ec.europa.eu/transparency/regdoc/rep/1/2014/EN/1-2014-15-EN-F2-1.Pdf

FAO. (2013). Biofuels and the sustainability challenge: A global assessment of sustainability issues, trends and policies for biofuels and related feedstocks. Retrieved from http://www.fao.org

FAO. (2015). FAOSTAT. Retrieved from http://faostat3.fao.org/home/E

FAO, IFAD, \& WFP. (2015). The state of food insecurity in the world 2015. Meeting the 2015 International hunger targets: taking stock of uneven progress. Retrieved from Rome: http://www.fao.org/publications

Fargione, J., Hill, J., Tilman, D., Polasky, S., \& Hawthorne, P. (2008). Land clearing and the biofuel carbon debt. Science, 319(5867), 1235-1238. doi:10.1126/science.1152747

Fernández, R. (2012). Escenarios-Energeticos-Argentina-2030, informe de sintesis, aportes para un debate energético national (pp. 23). Retrieved from http://www.escenariosenergeticos.org

FGV. (2010). Biodiesel and the contribution to the Brazilian development (in portuguese). Retrieved from http://www.ubrabio.com.br

Floyd, J. (2007). Thermodynamics, entropy and disorder in futures studies. Futures, 39(9), 1029-1044. doi:10.1016/j.futures.2007.03.011 
Fraiture, C. d., Giordano, M., \& Liao, Y. (2008). Biofuels and implications for agricultural water use: blue impacts of green energy. Water Policy, 10(S1), 67. doi:10.2166/wp.2008.054

Frederico, S. (2012). Agricultura científica globalizada e fronteira agrícola moderna no Brasil. Confins on line, 17. doi:DOI : 10.4000/confins. 8153

Gallagher, E. (2008). The Gallagher Review - the indirect effects of biofuels production. Retrieved from UK: http://www.renewablefuelsagency.org

Garcez, C. A. G., \& Vianna, J. N. d. S. (2009). Brazilian Biodiesel Policy: Social and environmental considerations of sustainability. Energy, 34(5), 645-654. doi:http://dx.doi.org/10.1016/j.energy.2008.11.005

Gazzoni, D. L. G. (2012a). Balanco de emissões de CO2 por biocombustiveis no Brasil, historico e perspectivas (334). Retrieved from http://www.cnpso.embrapa.br/download/Doc_334_OL.pdf

Gazzoni, D. L. G. (2012b). Balanco de emissões de CO2 por biocombustiveis no Brasil, historico e perspectivas. Embrapa Soja. Londrina, PR.

GBN. (2012). Developing and using scenarios, course material run in San Francisco, october, 2012.: GBN - global busines network.

GCEE. (2015). Better growth, better climate: the new climate economy report. Retrieved from http://www.newclimateeconomy.report

Georgescu-Rogen, N. (1971). The Entropy Law and the Economics Process: Ed. Havard.

German, L., Schoneveld, G. C., \& Gumbo, D. (2011). The Local Social and Environmental Impacts of Smallholder-Based Biofuel Investments in Zambia. Ecology and Society, 16(4). doi:10.5751/ES-04280-160412

Gil, A. C. (2011). Métodos e Técnicas de Pesquisa Social (6a. ed.): Editora Atlas.

Globo, G. (2015). Dilma promete reflorestar $120 \mathrm{mil} \mathrm{km²}$ e zerar desmatamento ilegal até 2030. Retrieved from http://g1.globo.com/mundo/noticia/2015/06/dilma-assina-nos-euacompromisso-para-zerar-desmatamento-ilegal.html

Godar, J. e. a. (2014). Actor-specific contributions to the deforestation slowdown in the Brazilian Amazon. PNAS, 111(43).

Godet, M. (2010). Future memories. Technological Forecasting and Social Change, 77(9), 1457-1463. doi:10.1016/j.techfore.2010.06.008

Godet, M., \& Durance, P. (2011). La prospective strategique - pour les entreprises et les territoires (2a. ed.). Paris, France: Dunod.

Gordon, T. J. (2007). Energy forecasts using a "Roundless" approach to running a Delphi study. Foresight, 9(2), 27-35. doi:10.1108/14636680710737731 
Gui, M. M., Lee, K. T., \& Bhatia, S. (2008). Feasibility of edible oil vs. non-edible oil vs. waste edible oil as biodiesel feedstock. Energy, 33(11), 1646-1653. doi:http://dx.doi.org/10.1016/j.energy.2008.06.002

Haas, M. J., McAloon, A. J., Yee, W. C., \& Foglia, T. A. (2006). A process model to estimate biodiesel $\begin{array}{llll}\text { production } \quad \text { costs. } & \text { Bioresource Technology, 97(4), }\end{array}$ doi:http://dx.doi.org/10.1016/j.biortech.2005.03.039

Hanafin, S. (2004). Review of literature on the Delph Technique. Retrieved from http://www.dcya.gov.ie/documents/publications/Delphi_Technique_A_Literature_Review.p df

Handl, G. (2014). :Declaration of the United Nations conference on the Human Environment; Rio Declaration on Environment and Development. Retrieved from http://legal.un.org/avl/ha/dunche/dunche.html

Harfuch, L. (2014). [Brazil map with 6 regions].

Helmer, O. (1967). Systematic use of expert opinions. Retrieved from http://www.rand.org/content/dam/rand/pubs/papers/2006/P3721.pdf

Hillier, F. S., \& J., L. G. (2010). Introduction to operations research (9a. ed.). Singapore: McGrawHill.

Hosonuma, N., Herold, M., De Sy, V., De Fries, R. S., Brockhaus, M., Verchot, L., . . Romijn, E. (2012). An assessment of deforestation and forest degradation drivers in developing countries. Environmental Research Letters, 7. doi:doi:10.1088/1748-9326/7/4/044009

Hsu, C.-C., \& Sandford, B. A. (2007). The Delphi technique: making sense of consensus. Practical assessment, research \& evaluation, 12(10).

IAEA. (2009). IAEA Tools and methodologies for enerrgy system planning and nuclear energy system assessments. Retrieved from https://www.iaea.org/sites/default/files/INPROPESSbrochure.pdf

IBGE. (2015a). Instituto Brasileiro de Geografia e Estatística. Retrieved from http://www.ibge.gov.br

IBGE. (2015b). Instituto Brasileiro de Geografia e Estatística - PAM - Pesquisa Agropecuária Municipal. Retrieved from http://www.ibge.gov.br

IEA. (2011). Technology Roadmap - biofuels for transport, 2050.

IEA. (2015a). Recent trends in world $\mathrm{CO}_{2}$ emissions from fuel combustion (2015 edition). Retrieved from https://www.iea.org/media/news/2015/news/151104_webarticle_CO2_FINAL.pdf

IEA. (2015b). WEO2015-Special Report on Energy and Climate Change. Retrieved from Paris: https://www.iea.org/publications/freepublications/publication/weo-2015-special-reportenergy-climate-change.html

IEA-International-Energy-Agency. (2015). WEO2015-ExecutiveSummary. Retrieved from Paris: http://www.iea.org 
IEA-task40. (2011). IEA bioenergy - Sustainable International Bioenergy Trade-Securing Supply and Demand. Retrieved from http://www.bioenergytrade.org/ongoing.html

IMAZON. (2015). ONGs lançam manifesto público sobre a Agenda Brasil. Retrieved from http://imazon.org.br/imprensa/ongs-lancam-manifesto-publico-sobre-a-agenda-brasil/

Inayatulaah, S. (1993). From "who am I" to "when am I?" framing the shape and time of the time. Futures.

Inayatulaah, S. (2002). Pedagogy, culture and future studies. In J. A. Dator (Ed.), Futures Studies in Higher Education. USA: Praeger Publishers.

Inayatullah, S. (1993). From who I am to when I am. Futures, 235-253.

Inayatullah, S. (2008). Six pillars: futures thinking for transforming. Foresight, 10(1), 4-21. doi:10.1108/146366808 10855991

INPE. (2015). PROJETO PRODES MONITORAMENTO DA FLORESTA AMAZÔNICA BRASILEIRA POR SATÉLITE. Retrieved from http://www.obt.inpe.br/prodes/index.php

IPCC. (2014). Climate Change 2014; Synthesis Report. contribution of Working Groups I,II and III to the fifth Assessment Report of the Intergovernmental Panel on Climate Change. Retrieved from Geneva, Switzerland, https://www.ipcc.ch/publications_and_data/ar4/wg3/en/contents.html

151pp:

IRENA. (2015). Renewable Energy and Jobs - Annual Review 2015. Retrieved from Dubai: http://www.irena.org

Jackson, T. (2009). Prosperity without growth? The transition to a sustainable economy. Retrieved from London: http://www.sd-commission.org.uk

Janssen, R., \& Rutz, D. D. (2011). Sustainability of biofuels in Latin America: Risks and opportunities. Energy Policy, 39(10), 5717-5725. doi:http://dx.doi.org/10.1016/j.enpol.2011.01.047

Jolliet, O., Saadé, M., \& Creattaz, P. (2005). Analyse du cicle de vie - comprendre et réaliser un ecoblian. Suisse: Presses polytecniques et universitaires.

Kahn, H., \& Wierner, A. J. (1967). The Year 2000: A Framework for Speculation on the Next ThirtyThree Years. New York, USA: The Macmillan.

Kennedy, H. P. (2004). Enhancing Delphi research: methods and results. Journal of Advanced Nursing, 45(5), 504-511.

Kochelmans, J. J. (1979). Why interdiscplinarity? In J. J. Kockelmans (Ed.), In Interdisciplinarity and higher education. London: The Pensylvania State University Press.

Landeta, J. (2006). Current validity of the Delphi method in social sciences. Technological Forecasting and Social Change, 73(5), 467-482. doi:10.1016/j.techfore.2005.09.002 
Lane, J. (2016). Biofuels mandates around the world: 2016. Biofuelsdigest.

Langevelde, H. S., \& Meeusen, M. (2010). The biobased economy The biobased economy. London: Earthscan.

Latouche, S. (2007). Petit traité de la décroissance sereine (M. e. u. Nuits Ed.). France.

Leiras, A., Hamacher, S., \& Scavarda, L. F. (2008). An Integrated Supply Chain Perspective Evaluation for Biodiesel Production in Brazil. Brazilian Journal of Operations \& Production Management, 5(2), 29-47.

Levermann, R. A., \& Souza, J. P. M. d. (2014, February, 2014). Oleo de palma - O crescimento da indústria global. AGROANALYSIS - a revista de agronegócio da FGV.

Lima, M., Skutsch, M., \& Costa, G. d. M. (2011). Deforestation and the Social Impacts of Soy for Biodiesel: Perspectives of Farmers in the South Brazilian Amazon. Ecology and Society, 16(4). doi:10.5751/ES-04366-160404

Lorek, S., \& Spangenberg, J. H. (2014). Sustainable consumption within a sustainable economy beyond green growth and green economies. Journal of Cleaner Production, 63, 33-44. doi:10.1016/j.jclepro.2013.08.045

Macedo, M., \& Castello, L. (2015). The state of the Amazon: Freswater connectivity and Ecosystem Health. Retrieved from Brasilia: http://d2ouvy59p0dg6k.cloudfront.net/downloads/wwf_livingamazon_state_of_the_amazo n_freshwaterconnectivity_links_web_eng.pdf

Malhotra, R. K. (2001). Pesquisa de Marketing - uma orientação aplicada (N. Montigelli Jr \& A. A. FArias, Trans. 3a. ed.). Porto Alegre: Bookman.

Marchand, A., \& Walker, S. (2008). Product development and responsible consumption: designing alternatives for sustainable lifestyles. Journal of Cleaner Production, 16(11), 1163-1169. doi:10.1016/j.jclepro.2007.08.012

Marcial, E. C., \& Grumbach, R. J. d. S. (2008). Grumbach method - strategic vision and consolidation (in portuguese) Prospective Scenarios, how to build a better future (in portuguese) (Fifth edition, revised and expanded ed., pp. 228). Rio de Janeiro: Editora FGV.

Maretti, C. C., Riveros S., J. C., Hofstede, R., Oliveira, D., Chrity, S., Granizo, T., . . . Thompson, C. (2014). State of the amazon: Ecological representation in prtected areas and indigenous territories.

Retrieved

from http://d2ouvy59p0dg6k.cloudfront.net/downloads/final_report_11_11_14.pdf

Martins, R., Nachiluk, K., Bueno, C. R. F. B., \& Freitas, S. M. (2011). O Biodiesel de sebo bovino no Brasil. Informacões economicas, 41(5).

McCarthy, K. (1992). Comment on the "analytic Delphi method". International Journal of Production Economics, 27. 
Meadows, D., Meadows, D., Randers, J., \& Behrens III, W. W. (1972). The limits to growth - a report for the club of Rome's project on the predicament of mankind (Vol. 1). New York, NY, USA: Universe Books.

Millennium-project. (2006). The state of future - Global Energy Scenarios 2020. Retrieved from http://www.millennium-project.org/

MILLER-KLEIN. (2006). Use of Tallow in Biodiesel. Retrieved from http://hgca.com/publications/documents/Use_of_Tallow_in_Biodiesel.pdf

Mintzberg, H., Ahlstrand, B., \& Lampel, J. (2000). Safari de estratégia - um roteiro pela selva do planejamento estratégico (N. M. Jr, Trans.). Porto Alegre, Brazil: Bookman.

Mintzer, I., Leonard, J. A., \& Schwartz, P. (2003). U.S Energy Scenarios for the 21st Century. Retrieved from http://www.c2es.org/docUploads/EnergyScenarios.pdf

Mont, O., Neuvonen, A., \& Lähteenoja, S. (2014). Sustainable lifestyles 2050: stakeholder visions, emerging practices and future research. Journal of Cleaner Production, 63(0), 24-32. doi:http://dx.doi.org/10.1016/j.jclepro.2013.09.007

Nationalgrid. (2015). Future energy scenarios - UK gas and electricity transmission. Retrieved from London, UK: http://www.nationalgrid.com

Nelson, R. G., \& Schrock, M. D. (2006). Energetic and economic feasibility associated with the production, processing, and conversion of beef tallow to a substitute diesel fuel. Biomass and Bioenergy, 30(6), 584-591. doi:http://dx.doi.org/10.1016/j.biombioe.2005.09.005

Nepstad, D. C., Stickler, C. M., \& Almeida, O. T. (2006). Globalization of the Amazon Soy and beef industries: opportunities for conservation. Conservation Biology, 20(6), 1595-1603. doi:10.1111/j.1523-1739.2006.00510.x

Ninio, M. (2015). Negociador de confiança de Obama crê em acordo global sobre clima. Retrieved from http://www1.folha.uol.com.br/mundo/2015/08/1672663-negociador-de-confianca-deobama-cre-em-acordo-global-sobre-clima.shtml

Nobre, A. D. (2015). o futuro climático da Amazônia (The climate future of the Amazon). Retrieved from Brasil:

Nogueira, L. A. H. (2011). Does biodiesel make sense? Energy, 36(6), 3659-3666. doi:http://dx.doi.org/10.1016/j.energy.2010.08.035

Nowack, M., Endrikat, J., \& Guenther, E. (2011). Review of Delphi-based scenario studies: Quality and design considerations. Technological Forecasting and Social Change, 78(9), 1603-1615. doi:10.1016/j.techfore.2011.03.006

Obidzinski, K., Andriani, R., Komarudin, H., \& Andrianto, A. (2012). Environmental and Social Impacts of Oil Palm Plantations and their Implications for Biofuel Production in Indonesia. Ecology and Society, 17(1). doi:10.5751/ES-04775-170125

OC. (2015). Análise das emissões de GEE no Brasil (1970 - 2013) e suas implicações para políticas públicas. Documento síntese in PORTUGUESE. Retrieved from seeg.eco.br 
OECD. (2014). The cost of air pollution - health impacts of road transport. Retrieved from http://dx.doi.org/10.1787/9789264210448-en

OECD-FAO. (2014). OECD-FAO Agricultural Outlook $2014 . \quad$ Retrieved from http://dx.doi.org/10.1787/agr_outlook-2014-en

OECD-FAO. (2015). Agricultural Outlook 2015. Retrieved from Paris: http://dx.doi.org/10.1787/agr_outlook-2015-en

OECD/IEA. (2015). Key World Statistics 2015. Retrieved from http://www.iea.org/publications/freepublications/publication/key-world-energy-statistics2015.html

Oliveira, L. B. (2004). Potencial de aproveitamente energético de lixo e de biodiesel de insumos residuais no Brasil. (PhD report), Universidade Federal do Rio de Janeiro, Rio de Janeiro.

Padula, A. D., Santos, M. S., Ferreira, L., \& Borenstein, D. (2012). The emergence of the biodiesel industry in Brazil: Current figures and future prospects. Energy Policy, 44, 395-405. doi:10.1016/j.enpol.2012.02.003

Palacio, J. C. E., Lora, E. E. S., Venturini, O. J., \& Olmo, O. A. d. (2010). Biocombustíveis, meio ambiente, tecnologia e seguranca alimentar. In E. E. S. V. Lora, Osvaldo José (Ed.), Biocombustíveis (1a. Ed. ed., Vol. 1, pp. 1158). Rio de Janeiro, Brasil: Editora Interciencia.

Pedroti, P. M. (2013). The challenges of development and social inclusion: the case of the politicalinstitutional arrangement of the Nacional Program of Productiona and Use of Biodiesel in Brazil (in portuguese). Retrieved from Rio de Janeiro: http://www.ipea.gov.br

Perdomo, I. C. (2006). Energía en Colombia 2005-2025: una visión hacia el futuro in Colombia Escenarios y Estrategias, mineria y energia. Retrieved from Bogotá, Colombia:

Pereira Jr, A. O., Soares, J. B., de Oliveira, R. G., \& de Queiroz, R. P. (2008). Energy in Brazil: Toward $\begin{array}{llll}\text { sustainable development? } & \text { 73-83. }\end{array}$ doi:http://dx.doi.org/10.1016/j.enpol.2007.08.022

PETROBRAS. (2014). Petrobras Biocombustível produzirá mais biodiesel a partir de óleo de cozinha usado. Retrieved from http://www.petrobras.com.br/fatos-e-dados/petrobrasbiocombustivel-produzira-mais-biodiesel-a-partir-de-oleo-de-cozinha-usado.htm

Piketty, T. (2014). Capital in the Twenty-first century (A. Goldhammer, Trans.). USA: Belknap Press.

Pillkahn, U. (2008a). Detection- detecting and recording changes in the enterprise environment Using trends and scenarios as tools for strategy development- shaping the future of your enterprise. Erlang, German: Publicis Corporate Publishing.

Pillkahn, U. (2008b). Understanding: antecipanting the future Using trends and scenarios as tools for strategy development. Erlang, Germany. 
Pillkahn, U., \& Sasano, S. (2008). Scenario development 2.0. Paper presented at the Third International Seville Seminar on Future-Oriented TEchnology Analysis: impacts and implications for policy and decision-making, SEville.

Pincombe, B., Blunden, S., Pincombe, A., \& Dexter, P. (2013). Ascertaining a hierarchy of dimensions from time-poor experts: Linking tactical vignettes to strategic scenarios. Technological Forecasting and Social Change, 80(4), 584-598. doi:10.1016/j.techfore.2012.05.001

Pinto, e. a. (2005). Biodiesel an overview. Journal of the Brazilian Chemical Society, 16(6B), 13131330.

Plesch, D., Austin, G., Grant, f., \& Sullivan, S. (2006). Bio-energy and CAP reform: the gains to Europe and Africa. Retrieved from London: http://fpc.org.uk/fsblob/714.pdf

Porter, M. E. (1980). Competitive Strategy, techniques for analysing industries and competitors. USA: The free press.

Porto, C. (2001). Modelos e cenarios para a Amazônia: o papel da ciência. Macrocenarios da Amazônia. Retrieved from http://www.macroplan.com.br/MonCenarios_Item.aspx?ld=3

Porto, C., Nascimento, E., \& Buarque, S. C. (2001). Why and how to explor likely futures (in portuguese) Five scenarios for Brazil, from 2001-2003. Rio de Janeiro: Nórdica.

Powel, C. (2003). The Delphi Technique Myths and Realities. Methodological issues in nursing research - Journal of Advanced Nursing,, 41(4).

Raman, S., \& Mohr, A. (2014). Biofuels and the role of space in sustainable innovation journeys. J Clean Prod, 65(100), 224-233. doi:10.1016/j.jclepro.2013.07.057

Rathmann, R., Szklo, A., \& Schaeffer, R. (2012). Targets and results of the Brazilian Biodiesel Incentive Program - Has it reached the Promised Land? Applied Energy, 97(0), 91-100. doi:http://dx.doi.org/10.1016/j.apenergy.2011.11.021

Ravindranath. (2007). GHG Implications of Land Use and Land Conversion to Biofuel Cropsin SCOPE Biofuel Repor.

REN21. (2014). Global status report. Retrieved from Paris: http://www.ren21.net/status-ofrenewables/global-status-report/?gclid=CliGrPmoxckCFQEoHwodujUGsQ

Richardson, R. J. (2012). Pesquisa Social, métodos e técnicas (3a. ed revista e ampliada ed.). São Paulo, Brazil: Atlas.

Rockstrom, J., Steffen, W., Noone, K., Persson, A., Chapin, F. S., Lambin, E. F., . . Foley, J. A. (2009). A safe operating space for humanity. Nature, 461(7263), 472-475.

Rogers, E. M. (2003). Diffusion of Innovations (Fifth edition ed.). USA: Free Press.

Roinioti, A., Koroneos, C., \& Wangensteen, I. (2012). Modeling the Greek energy system: Scenarios of clean energy use and their implications. Energy Policy, 50, 711-722. doi:10.1016/j.enpol.2012.08.017 
Rovere, E. L. L., Pereira, A. S., \& Simões, A. F. (2011). Biofuels and Sustainable Energy Development in Brazil. World Development, 39(6), 1026-1036. doi:10.1016/j.worlddev.2010.01.004

S\&T2. (2015). GHG emission reductions from world biofuel production and use - 2015. Retrieved from http://globalrfa.org

Sachs, I. (2002). Caminhos para o desenvolvimento sustentável (2a. ed.). Rio de Janeiro: Garamond.

Sachs, I. (2004). Desenvolvimento includente, sustentavel e sustentado. Rio de Janeiro, Brazil: Garamond.

Sallet, C. L., \& Alvim, A. M. (2011). Biocombustíveis: uma análise da evolucão do biodiesel no Brasil. Economia \& Tecnologia, 25(April/June 2011).

SANFORD, S. D., WHITE, J. M., SHAH, P. S., WEE, C., VALVERDE, M. A., \& MEIER, G. (2009). Feedstock and Biodiesel Characteristics Report. Retrieved from: http://www.thebioenergysite.com

Santos, J. A. (2013). Os impactos na economica brasileira, pela substituição dos combustiveis fosseis por ethanol e biodiesel, de 2010 a 2030. (PhD), University of Sao Paulo, Piracicaba.

Saúde-e-Sustentabilidade, I., \& APROBIO. (2015). Avaliação dos impactos na saúde e sua valoração devido à implementação progressiva do componente biodiesel na mistura da matriz energética (diesel) de transporte. Retrieved from São Paulo: http://www.aprobio.com.br

Schoneveld, G. C., German, L. A., \& Nutakor, E. (2011). Land-based Investments for Rural Development? A Grounded Analysis of the Local Impacts of Biofuel Feedstock Plantations in Ghana. Ecology and Society, 16(4). doi:10.5751/ES-04424-160410

Schwartz, P. (1996). The art of the long view: Planning for the future in an uncertain world. USA: Currency Doubleday.

SEEG/OC. (2015). Synthesis document: analysis of the GHG in Brazil 1970-2013 and the implications to the public policies, 2014. Retrieved from São Paulo, Brazil: http://seeg.eco.br/analise-deemissoes-brasileiras-de-gee-no-brasil-1970-2013/

SEI-Stockholm-Environment-Institute. (2015). LEAP-Long range Energy Alternatives Planning System. Retrieved from http://www.seiinternational.org/mediamanager/documents/Publications/Climate-mitigationadaptation/SEI-LEAP-brochure-Jan2012.pdf

Selltiz, G. e. a. (1965). Métodos de pesquisa nas relações sociais. São Paulo: Herder.

SHELL. (2008). Shell energy scenarios to 2050. Retrieved from http://www.shell.com/scenarios

Shoemaker, P. J. H. (1995). Scenario Planning: a tool for strategic thinking. Sloan Managment Review, $37(2), 25-40$.

Shumaker, G., McKissick, J., Ferland, C., \& Doherty, B. (2003). A study of the feasibility of biodiesel production in Georgia. Retrieved from Georgia, USA: 
Silva, J. F. V., Richetti, A., Hirakuri, M. H., \& Castro, A. M. G. (2010). Sistema produtivo de soja para a produção de biodiesel Complexo Agoindustrial de Biodiesel no Brasil: competitividade das cadeias produtivas de matérias-primas. Brasilia: Embrapa.

Slaughter, R. (2002). Futures Studies as an intelectual and applied discipline. In J. A. Dator (Ed.), Future Studies in High education. USA: Praeger Publishers.

Soares M.C. Borba, B., Szklo, A., \& Schaeffer, R. (2012). Plug-in hybrid electric vehicles as a way to maximize the integration of variable renewable energy in power systems: The case of wind generation in northeastern Brazil. Energy, 37(1), 469-481. doi:10.1016/j.energy.2011.11.008

Soares-Filho, B. S. (2013). The impact of the forest law revision: how to turn the big challenge ahead, viable? (in portuguese). Retrieved from Brasilia: http://www.socioambiental.org/sites/blog.socioambiental.org/files/nsa/arquivos/artigocodigo-florestal_britaldo_soares_sae_2013pdf.pdf

Sousa, C. S. G. d. (2013). Cenários prospectivos da producao de biodiesel no Brasil, em 2020. (Master), Federal University of Paraiba, Paraiba, Brazil.

Sparovek, G., Barretto, A. G. O. P., Matsumoto, M., \& Berndes, G. (2015). Effects of governance on availability of land for agriculture and conservation in Brazil. Environmental science \& technology. doi:10.1021/acs.est.5b01300

STATEOFGREEN. (2015). Energy scenarios for 2020, 2035 and 2050. Retrieved from Denmark: https://stateofgreen.com/en

Steffen, W., Richardson, K., Rockström, J., Cornell, S. E., Fetzer, I., Bennett, E. M., . . Sörlin, S. (2015). Planetary boundaries: guiding human development on a changing planet. Sciencexpress.

Stitt-Gohdes, W. L., \& Crews, T. B. (2004). The delphi technique: a research strategy for career and technical education. Journal of Career and Technical Education, 20(2).

Tapio, P., Paloniemi, R., Varho, V., \& Vinnari, M. (2011). The unholy marriage? Integrating qualitative and quantitative information in Delphi processes. Technological Forecasting and Social Change, 78(9), 1616-1628. doi:10.1016/j.techfore.2011.03.016

Turoff, M. (1975). The policy Delphi The Delphi method: Techniques and applications. London: Addison-Wesley.

UFOP. (2013). Union zur Förderung von Oel, Biodiesel feestock. Retrieved from http://www.ufop.de/english/bio-fuels/

UN. (1987). Brundtland Report - Our common future. Retrieved from

UN. (2015). Adoption of the Paris agreement, proposal by the President, draft decision. Retrieved from https://unfccc.int/resource/docs/2015/cop21/eng/l09r01.pdf

UNEP. (2010). The emissions gap report: are the Copenhagen accord pledges sufficient to limit global warming to $2^{\circ} \mathrm{C}$ or $1.5^{\circ} \mathrm{C}$ ? A preliminary assessement, techinal summary. Retrieved from http://uneplive.unep.org/theme/index/13 -.VmMrFLiDFBc 
UNEP. (2015). The emissions gap report 2015 - executive summary. Retrieved from http://uneplive.unep.org/theme/index/13 - indcs

UNFCC. (2010). Copenhagen Climate Change Conference, decision -/CP.15. Retrieved from http://unfccc.int/meetings/copenhagen_dec_2009/meeting/6295/php/view/decisions.php

UNWATER. (2013). Water-cooperation 2013, facts and figures. Retrieved from http://www.unwater.org/water-cooperation-2013/water-cooperation/facts-and-figures/en/

USA/EERE. (2015). HYDROGEN AND FUEL CELLS. Retrieved from http://energy.gov/eere/fuelcells/fuel-cell-technologies-office

USDA. (2015). Oilseeds: World Markets and Trade. Retrieved from http://www.fas.usda.gov/data/search?f\%5B0\%5D=field_commodities\%3A26

USDOE. (2014). HYDROGEN AND FUEL CELLS Program. 2014 annual progress report. Retrieved from http://energy.gov/eere/transportation/hydrogen-and-fuel-cells,

USDOE-US-Department-of-Energy). (2009). Alternative Fuels \& Advanced Vehicles Data Center. Energy Efficiency and Renewable energy,. Retrieved from http://www.afdc.energy.gov/afdc/

Vaccaro, G. L. R., Pohlmann, C., Lima, A. C., dos Santos, M. S., de Souza, C. B., \& Azevedo, D. (2010). Prospective scenarios for the biodiesel chain of a Brazilian state. Renewable and Sustainable Energy Reviews, 14(4), 1263-1272. doi:http://dx.doi.org/10.1016/j.rser.2009.12.008

Van Der Heijden, K. (2005). Scenarios - the art of strategic conversation (2a. ed.). UK: John Wiley \& sons, Ltd.

Van Gerpen, J., Shanks, B., Prusko, R., Clementes, D., \& Knothe, G. (2004). Biodiesel production technology report NRELSR-510-36244. USA: National energy laboratory.

Varum, C. A., \& Melo, C. (2010). Directions in scenario planning literature - A review of the past decades. Futures, 42(4), 355-369. doi:10.1016/j.futures.2009.11.021

Vianna, J. N. d. S., Dias, M. A. d. P., Alves, A. S. H., \& Lopes, M. (2013). Opportunities and challenges for Biodiesel in the XXI century. In M. Lopes, T. L, I. Ribeiro, A. Monteiro, H. Martins, S. Rafael, A. I. Miranda, \& C. Borrego (Eds.), (Vol. 1, pp. 59-65). Aveiro, Portugal.

Vianna, J. N. d. S., Duarte, L. M. G., \& Wehrmann, M. (2010). The limits of biodiesel for pormoting social inclusion, energy security, biodiversity protection and food security. In M. Sens \& R. Mondardo (Eds.), Science and TEchnology for Environmental Studies: Ed copiart.

Vianna, J. N. d. S., Wehrmann, M., \& Duarte, L. M. G. (2009). Soybean and the contribution of oilseeds to biodiesel production in Brazil. In L. M. G. Duarte \& P. Pinto (Eds.), Sustainable development: energy, environment and natural disasters (pp. 71-91). Évora: Fundacão Luis de Molina.

Victor, P. (2010). Questioning economic growth. Nature, 468(7322), 370-371. 
Wack, P. (1985). Scenarios: uncharted waters ahead. Harvard Business Review(September 1985).

Wassenaar, T., \& Kay, S. (2008). Biofuels: one of the many claims to resources. Science, 321(5886). doi:0.1126/science.321.5886.201

WEC. (2013). World Energy Scenarios: Composing energy futures to 2050. Retrieved from London, UK: https://www.worldenergy.org/publications/2013/world-energy-scenarios-composingenergy-futures-to-2050/

WEC. (2015a). New Zeland Energy Scenarios- navigating energy futures to 2050. Retrieved from https://www.bec.org.nz/projects/bec2050

WEC. (2015b). World EnergyTrilemma: Priority actions on climate change and how to balance the trilemma. Retrieved from https://www.worldenergy.org/publications/2015/world-energytrilemma-2015-priority-actions-on-climate-change-and-how-to-balance-the-trilemma/

Weick, K. E. (1990). Cartographic Myths in Organizations. In A. S. Huff (Ed.), Mapping strategic thoughts. New York, NY, USA: Jonh Wiley \& sons, Ltd.

Wilkinson, A. (2009). Scenarios practices: in search of theory. Journal of Futures Studies, 13(3), 107114.

Wilkinson, A., Kupers, R., \& Mangalagiu, D. (2013). How plausibility-based scenario practices are grappling with complexity to appreciate and address 21st century challenges. Technological Forecasting and Social Change, 80(4), 699-710. doi:10.1016/j.techfore.2012.10.031

Wilson, I. (1998). Mental maps of the future: an intuitive logics Approach to scenarios. In L. F. R. M. Randall (Ed.), Learning from the future - competitive Foresight Scenarios. USA: John Wiley \& sons, Ltd.

WORLDBANK. (2011). Brazil low carbon case study - technical Synthesis report: land use, land-use change, and forestry. Retrieved from

WORLDBANK. (2015). Global Economic Prospects. Retrieved from http://databank.worldbank.org/data/reports.aspx?source=global-economic-prospects)

WWF. (2014). Living Planet Report 2014, Species and spaces, people and places. Retrieved from http://www.wwf.org

WWF-Ecofys. (2011). The energy report- 100\% renewable energy by 2050 . Retrieved from Switzerland: http://www.panda.org

Xavier, M., Bassi, A., de Souza, C., Filho, W., Schleiss, K., \& Nunes, F. (2013). Energy scenarios for the Minas Gerais State in Brazil: an integrated modeling exercise using System Dynamics. Energy, Sustainability and Society, 3(1), 1-13. doi:10.1186/2192-0567-3-17

Yunnus, M. (2001). Banker to the poor: Oxford UNiversity Press.

Zhang, Y., Dubé, M. A., McLean, D. D., \& Kates, M. (2003). Biodiesel production from waste cooking oil: 2. Economic assessment and sensitivity analysis. Bioresource Technology, 90(3), 229-240. doi:10.1016/s0960-8524(03)00150-0 
ANNEX I - COMPLETE LIST OF INTERVIEWEES AND PANELLISTS

Interviewees 34 people, 18 organizations

\begin{tabular}{|c|c|c|}
\hline & \multicolumn{2}{|c|}{ Ministries and Presidency of Republic of Brazil } \\
\hline 1 & $\begin{array}{l}\text { Jose Accarini, Assistant deputy chief for } \\
\text { analysis and following up of government } \\
\text { policies; substitute of the biodiesel federal } \\
\text { program coordinator }\end{array}$ & $\begin{array}{l}\text { Presidency of Republic of Brazil, Office } \\
\text { of the chief of staff for the presidency }\end{array}$ \\
\hline 2 & $\begin{array}{l}\text { Ricardo de Gusmão Dornelles, Director of } \\
\text { the department of renewable fuels }\end{array}$ & \multirow[b]{2}{*}{ Ministry of Mines and Energy } \\
\hline 3 & $\begin{array}{l}\text { João Antônio Moreira Patusco, General } \\
\text { coordination of biofuel planning } \\
\text { coordination of energy information. }\end{array}$ & \\
\hline 4 & $\begin{array}{l}\text { Marcio Hirata from Bureau of Land } \\
\text { Regularization in the Amazon/ Director of } \\
\text { Planning, Monitoring and Evaluation } \\
\text { Secretariat substitute }\end{array}$ & \multirow[t]{2}{*}{ Ministry of Agrarian Development } \\
\hline 5 & 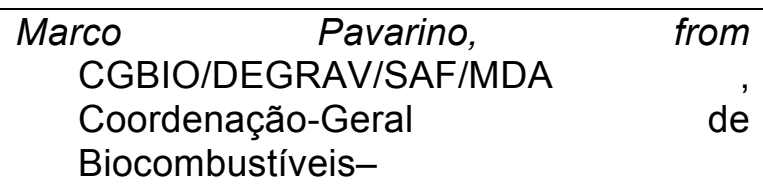 & \\
\hline 6 & $\begin{array}{l}\text { João da Silva Abreu Neto, General } \\
\text { coordinator of agroenergy }\end{array}$ & $\begin{array}{l}\text { Ministry of Agriculture, Livestock and } \\
\text { Food Supply, Secretariat of Production } \\
\text { and Agro-energy }\end{array}$ \\
\hline 7 & $\begin{array}{l}\text { Rafael Menezes, Energy R\&D Coordinator, } \\
\text { General coordination for sector } \\
\text { Technologies }\end{array}$ & \multirow{2}{*}{$\begin{array}{l}\text { Ministry of Science, Technology and } \\
\text { Innovation. Secretariat of Technological } \\
\text { development and innovation }\end{array}$} \\
\hline 8 & $\begin{array}{l}\text { Gustavo de Lima Ramos, } \\
\text { coordinator for actions of } \begin{array}{l}\text { Substitute } \\
\text { development }\end{array}\end{array}$ & \\
\hline 9 & $\begin{array}{l}\text { Luciano Cunha de Sousa, Foreign trade } \\
\text { coordinator. }\end{array}$ & $\begin{array}{l}\text { Ministry of development, industry and } \\
\text { foreign trade }\end{array}$ \\
\hline & \multicolumn{2}{|c|}{ Nacional agency } \\
\hline 10 & $\begin{array}{l}\text { Rosângela Moreira de } \\
\text { Superintendent of Biofuels and Proújo, } \\
\text { Quality }\end{array}$ & \multirow{5}{*}{$\begin{array}{l}\text { ANP - National agency for petroleum } \\
\text { natural gas and biofuels, } \\
\text { Superintendence of biofuels and } \\
\text { product quality }\end{array}$} \\
\hline 11 & Fernanda Vieira Pinto & \\
\hline 12 & Marcela Flores & \\
\hline 13 & Jackson Albuquerque & \\
\hline 14 & Cristiane & \\
\hline & \multicolumn{2}{|c|}{ Brazil Energy Research Company } \\
\hline 15 & Pedro Ninô de Carvalho & $\begin{array}{l}\text { Brazil Energy Research Company EPE } \\
\text { (linked to Ministry of Mines and Energy), } \\
\text { Team responsible for Bioenergy } \\
\text { Research }\end{array}$ \\
\hline
\end{tabular}




\begin{tabular}{|c|c|c|}
\hline 16 & Euler João Geraldo da Silva & \\
\hline & \multicolumn{2}{|c|}{ Brazilian Agricultural Research Corporation } \\
\hline \multirow[t]{2}{*}{17} & Manoel Teixeira Souza Jr. Director-general & $\begin{array}{l}\text { EMBRAPA: Brazilian Agricultural } \\
\text { Research Corporation - Agroenergy }\end{array}$ \\
\hline & \multicolumn{2}{|c|}{ Producers } \\
\hline 18 & $\begin{array}{l}\text { Julio Cesar Minelli }- \text { Superintendent } \\
\text { Director }\end{array}$ & \multirow[t]{2}{*}{$\begin{array}{l}\text { APROBIO- Brazilian association of } \\
\text { biodiesel producers }\end{array}$} \\
\hline 19 & Antonio Ventilii - Assessor técnico & \\
\hline 20 & Odacir Klein - former Ubrabio President & \multirow[t]{2}{*}{$\begin{array}{l}\text { UBRABIO Brazilian association of } \\
\text { biodiesel }\end{array}$} \\
\hline 21 & $\begin{array}{l}\text { Professor Doctor Donato Aranda, Assessor } \\
\text { (also professor at Federal University of Rio } \\
\text { de Janeiro) }\end{array}$ & \\
\hline & \multicolumn{2}{|c|}{ Workers representative } \\
\hline 22 & $\begin{array}{llll}\text { Antoninho } & \text { Rovaris } & - & \text { Environment } \\
\text { Secretary } & & & \end{array}$ & $\begin{array}{l}\text { National Confederation of Agriculture } \\
\text { Workers }\end{array}$ \\
\hline & \multicolumn{2}{|c|}{ Congressmen } \\
\hline 23 & Deputy Evandro Gussi & $\begin{array}{l}\text { President of Parliamentary Front } \\
\text { Biodiesel }\end{array}$ \\
\hline 24 & Gilney Vianna & $\begin{array}{l}\text { Former deputy, pioneer in the discussion } \\
\text { of biodiesel in the Chamber of } \\
\text { Deputies }\end{array}$ \\
\hline & \multicolumn{2}{|c|}{ Professors, researches } \\
\hline 25 & Ronaldo Perez & University of Viçosa \\
\hline 26 & Donato Aranha & University of Rio de Janeiro \\
\hline 27 & Ole John Nielsen & University of Copenhagen \\
\hline \multirow[t]{2}{*}{28} & Gerd Sparoveck & University of São Paulo/ESALQ \\
\hline & \multicolumn{2}{|c|}{ Dealers } \\
\hline 29 & Ricardo R A X Menezes, vice president & $\begin{array}{l}\text { Union of Brazilian regional distributors of } \\
\text { fuels }\end{array}$ \\
\hline \multirow[t]{2}{*}{31} & Sandro Paes & Petrobrás \\
\hline & \multicolumn{2}{|c|}{ Minor producers } \\
\hline 31 & Adilson Liebsch, former management & AMYRIS \\
\hline 32 & Celia Marcondes Smith & Ecoleo \\
\hline
\end{tabular}




\begin{tabular}{|c|l|l|}
\hline & \multicolumn{2}{|c|}{ Others } \\
\hline 33 & $\begin{array}{l}\text { Scott Vaughan, President and Chief } \\
\text { Executive Officer }\end{array}$ & $\begin{array}{c}\text { IISD- International Institute for } \\
\text { Sustainable Development }\end{array}$ \\
\hline 34 & $\begin{array}{c}\text { Miguel Angelo Simczak Vedana, Executive } \\
\text { diretor }\end{array}$ & BiodieselBr (Magazine) \\
\hline
\end{tabular}

Panellists invited ( 35 ), answers: 21, 18 organizations

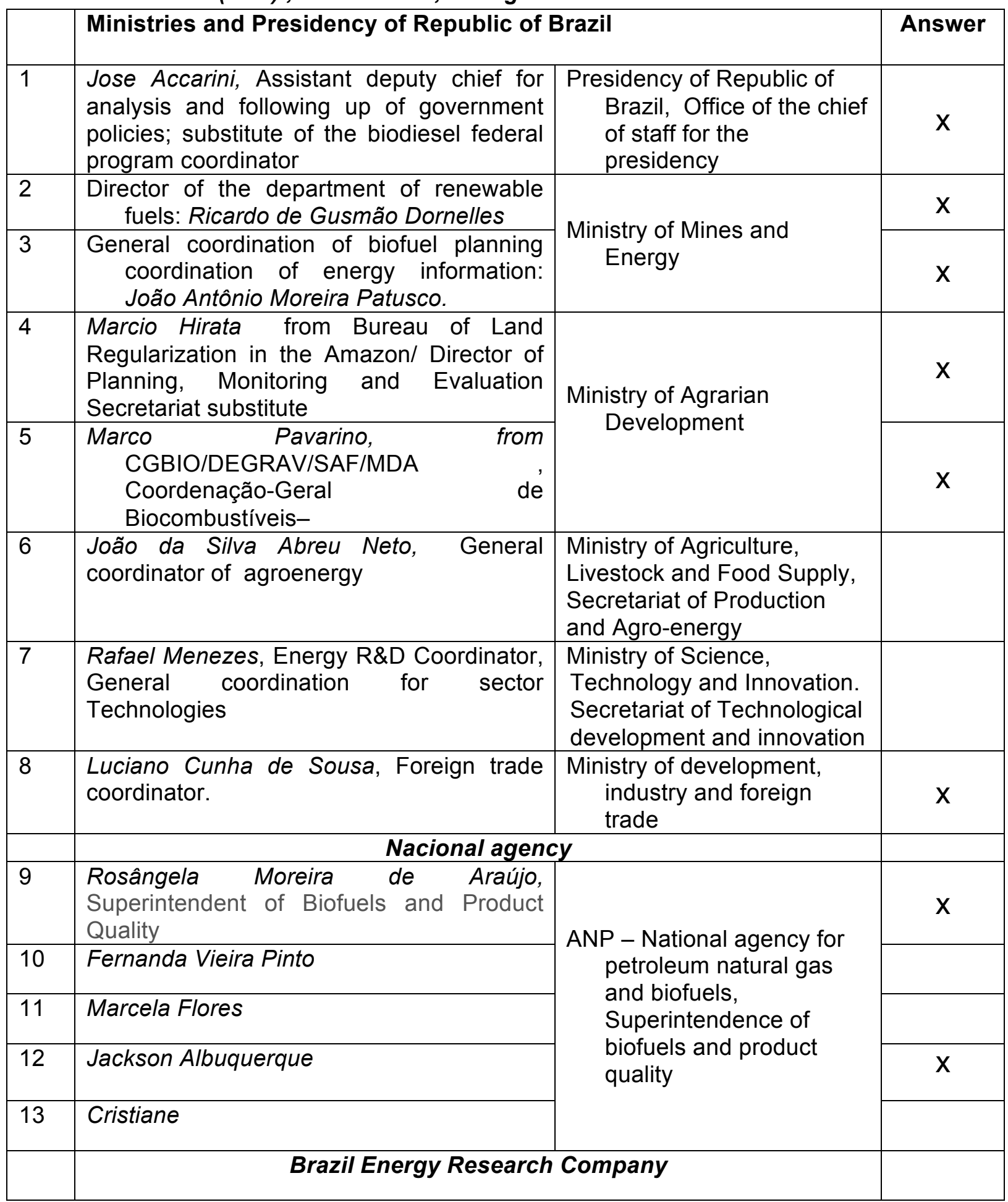




\begin{tabular}{|c|c|c|c|}
\hline 14 & Pedro Ninô de Carvalho & \multirow{2}{*}{$\begin{array}{l}\text { Brazil Energy Research } \\
\text { Company EPE (linked to } \\
\text { Ministry of Mines and } \\
\text { Energy), Team responsible } \\
\text { for Bioenergy Research }\end{array}$} & $\mathrm{X}$ \\
\hline 15 & Euler João Geraldo da Silva & & \\
\hline & \multicolumn{2}{|c|}{ Brazilian Agricultural Research Corporation } & \\
\hline \multirow[t]{2}{*}{16} & Manoel Teixeira Souza Jr. Director-general & $\begin{array}{l}\text { EMBRAPA: Brazilian } \\
\text { Agricultural Research } \\
\text { Corporation - Agroenergy }\end{array}$ & $\mathrm{x}$ \\
\hline & \multicolumn{2}{|l|}{ Producers } & \\
\hline 17 & $\begin{array}{l}\text { Julio Cesar Minelli }- \text { Superintendent } \\
\text { Director }\end{array}$ & $\begin{array}{l}\text { APROBIO- Brazilian } \\
\text { association of biodiesel } \\
\text { producers }\end{array}$ & $\mathrm{X}$ \\
\hline \multirow[t]{2}{*}{18} & $\begin{array}{l}\text { Professor Doctor Donato Aranda, Assessor } \\
\text { (also professor at Federal University of Rio } \\
\text { de Janeiro) }\end{array}$ & $\begin{array}{l}\text { UBRABIO Brazilian } \\
\quad \text { association of biodiesel }\end{array}$ & \\
\hline & \multicolumn{2}{|c|}{ Workers representative } & \\
\hline \multirow[t]{2}{*}{19} & $\begin{array}{llll}\text { Antoninho } & \text { Rovaris } & - & \text { Environment } \\
\text { Secretary } & & & \\
\end{array}$ & $\begin{array}{c}\text { National Confederation of } \\
\text { Agriculture Workers }\end{array}$ & \\
\hline & \multicolumn{2}{|c|}{ Congressmen } & \\
\hline \multirow[t]{2}{*}{20} & Deputy Evandro Gussi & $\begin{array}{l}\text { President of Parliamentary } \\
\text { Front Biodiesel }\end{array}$ & $\mathrm{X}$ \\
\hline & \multicolumn{2}{|c|}{ Professors, researches } & \\
\hline 21 & Ronaldo Perez & University of Viscosa & $\mathrm{x}$ \\
\hline 22 & Donato Aranha & University of Rio de Janeiro & \\
\hline 23 & Ole John Nielsen & University of Copenhagen & $x$ \\
\hline 24 & Gerd Sparoveck & $\begin{array}{l}\text { University of São } \\
\text { Paulo/ESALQ }\end{array}$ & \\
\hline 25 & Ricardo Sodré & $\begin{array}{l}\text { Catholic University of Minas } \\
\text { Gerais }\end{array}$ & $x$ \\
\hline 26 & João Nildo de Souza Vianna & University of Brasilia & $\mathrm{x}$ \\
\hline 27 & Antonio Sergio Hadad Alves & & $\mathrm{x}$ \\
\hline \multirow[t]{2}{*}{28} & Demóstenes Barbosa da Silva & University of Campinas & $x$ \\
\hline & \multicolumn{2}{|l|}{ Dealers } & \\
\hline 29 & Ricardo R AX Menezes, vice president & $\begin{array}{l}\text { Union of Brazilian regional } \\
\text { distributors of fuels }\end{array}$ & $\mathrm{X}$ \\
\hline \multirow[t]{2}{*}{30} & Sandro Paes & Petrobrás & \\
\hline & \multicolumn{2}{|c|}{ Minor producers } & \\
\hline 31 & Adilson Liebsch, former management & AMYRIS & \\
\hline \multirow[t]{2}{*}{32} & Márcia Tagore & Ecodendê & $\mathrm{X}$ \\
\hline & \multicolumn{2}{|l|}{ Others } & \\
\hline
\end{tabular}




\begin{tabular}{|l|l|l|c|}
\hline 33 & $\begin{array}{l}\text { Scott Vaughan, President and Chief } \\
\text { Executive Officer }\end{array}$ & $\begin{array}{l}\text { IISD- International Institute } \\
\text { for Sustainable } \\
\text { Development }\end{array}$ & \\
\hline 34 & Jose Berger & Evonik & $\mathrm{X}$ \\
\hline 35 & Professor Manfred Nitsch & Independent consultant & $\mathrm{X}$ \\
\hline
\end{tabular}

